\title{
Chiny z perspektywy XXI wieku
}

\author{
Redakcja naukowa \\ Joanna Marszałek-Kawa \\ Krzysztof Zamasz
}




\section{Seria \\ Biblioteka Azji i Pacyfiku \\ Redaktor Serii \\ Joanna Marszałek-Kawa}

\section{Sekretarz Serii}

Bartosz Ptotka

\section{Rada Serii}

Kamal M. Abdulla (Azerbejdżan), Daulet L. Baideldinov (Kazachstan), Marceli Burdelski (Gdańsk), He Yaomin (Chiny),

Hassan A. Jamsheer (Łódź), Vasyl Marchuk (Ukraina), Joanna Marszatek-Kawa (Toruń), Miao Huashou (Chiny),

Vladimir I. Nifadiev (Kirgistan), Ewa Oziewicz (Gdańsk),

Zdzisław Puślecki (Poznań), Akmal Saidov (Uzbekistan),

Grażyna Strnad (Kraków), Peter Vorel (Czechy)

Recenzenci tomu

dr hab. Andrzej Stelmach, prof. UAM

dr hab. Jarosław Nocoń, prof. UG

Redaktor prowadzący: Pawet Jaroniak

Redakcja techniczna: Ryszard Kurasz

Korekta: Zespót

Projekt okładki: Krzysztof Galus

(C) Copyright by Wydawnictwo Adam Marszałek

Wszystkie prawa zastrzeżone. Książka, którą nabyłeś, jest dziełem twórcy i wydawcy. Żadna jej część nie może być reprodukowana jakimkolwiek sposobem - mechanicznie, elektronicznie, drogą fotokopii itp. - bez pisemnego zezwolenia wydawcy. Jeśli cytujesz fragmenty tej książki, nie zmieniaj ich treści i koniecznie zaznacz, czyje to dzieło

Toruń 2020

ISBN 978-83-8180-313-7

Wydawnictwo prowadzi sprzedaż wysyłkową:

tel./fax 566485070 , marketing@marszalek.com.pl

Wydawnictwo Adam Marszałek, ul. Lubicka 44, 87-100 Toruń

tel. 5666422 35, 5666081 60, e-mail: info@marszalek.com.pl, www.marszalek.com.pl

Drukarnia, ul. Warszawska 54, 87-148 Łysomice, tel. 566783478 


\section{Spis treści}

Wstęp

\section{Marcin Przech}

Główne kierunki polityki zagranicznej Chińskiej

Republiki Ludowej w świetle konferencji prasowej

ministra spraw zagranicznych ChRL Wang Yi

w dniu 8 marca 2018 r. Kontynuacja i nowe akcenty

\section{Mateusz Wróblewski}

Strategiczne partnerstwo chińsko-rosyjskie w sektorze energetycznym 2014-2019

\section{Renata Podgórzańska}

Polityka Chińskiej Republiki Ludowej wobec Bałkanów

Zachodnich

\section{Wioleta Gierszewska}

Obecność Chin w Rwandzie w sferze

polityczno-gospodarczej

\section{Marcin Czyżniewski}

Kwestia Tybetu w stosunkach czesko-chińskich

\section{Maria Magdalena Sztuka}

Chińska decyzja administracyjna o ukaraniu cechy językowe 


\section{Iwona Grodź}

Zhang Yimou. Między prawdą a iluzją...

\section{Youyou Lu}

Tradycyjne chińskie symbole w chińskiej sztuce współczesnej

\section{Katarzyna Matuszczyk-Lu}

Między tradycją a innowacją - chińska architektura współczesna

\section{Helena Jadwiga Błazińska}

System nauczania w dawnych Chinach

\section{Anna Gryszkiewicz}

Symbolika tańca w kole plemienia Amis podczas

Święta Żniw w Yuli na Tajwanie - ujęcie postkolonialne ... 172

\section{Kornel Bielawski}

Indonezja po wyborach powszechnych w 2019 r.: w stronę rozwiązań nieliberalnych?

\section{Katarzyna Sopolińska}

Wybory parlamentarne w Bhutanie w latach 2008-2018 ... 207 


\section{Wstęp}

Aktualna międzynarodowa pozycja Chin została ukształtowana w wyniku wieloletnich reform, wewnętrznych przemian oraz transformacji polityki zagranicznej. W pierwszym etapie w sferze ekonomicznej główną rolę odegrała reforma rolna i tworzenie gospodarki rynkowej. W politycznej zaś odrzucono ideologię na rzecz pragmatyzmu i stopniowego postępu. Modyfikując wzorce rozwojowe azjatyckich tygrysów i Japonii, dokonano fuzji gospodarki rynkowej z etatyzmem. Ułatwiło to przeprowadzenie trzeciego etapu reform i zapoczątkowanie procesu budowy silnej pozycji w światowym systemie gospodarczym. Oznaczało to gruntowną przebudowę systemu gospodarczego, zarówno wewnątrz kraju, jak i w międzynarodowych relacjach gospodarczych. Ich polityczny wymiar postrzegany był w kategorii renesansu państwa i narodu oraz objęcia roli pierwszego światowego mocarstwa. Procesy tych przeobrażeń obok szerokiego dyskursu politycznego i prawnego doczekały się już licznych opracowań naukowych. Ukazało się wiele cennych prac uczonych chińskich i badaczy z różnych stron świata. Prace autorstwa A. Bruneta, J.P. Guicharda, D. Cohena, B. Liberskiej, J. Manna, B. Góralczyka, H. Kissingera, M. Leonarda, R. Kagana, M. Dillona, L.K. Yewa, M. Kłaczyńskiego i innych analizowały zachodzące zmiany w układzie ekonomicznym, prawnym, politycznym i społecznym. Charakteryzowały też nurty filozoficzne tych przemian. Często „marzycielami” nazywano nacjonalistów głoszących powrót do wielkości po „stu latach upokorzeń”, piewców asertywnej mocarstwowości z jednoczesnym odrzuceniem wpływów zachodnich. Drugą grupę stanowiła „narodowa esencja”, po- 
siadająca silny rys neokonfucjański, w skrajnych zaś przypadkach skłaniająca się do zastąpienia wyczerpującego się systemu (post)leninowskiego systemem wywodzącym się z koncepcji inspirowanych myślą Konfucjusza. I wreszcie „realiści”, wskazujący na wyczerpanie się systemu, głównie w zakresie gospodarczym i sugerujący konieczność przeprowadzenia reform. Dostrzeżono także transformację sinocentrycznego porządku tian xia, rozważając, czy może on mieć charakter uniwersalny i jak w jego kontekście mogą się kształtować relacje z innymi państwami. Zderzenie cywilizacji zastąpiono fuzją mającą doprowadzić do zbudowania potęgi Chin na arenie międzynarodowej. Odejście od "modelu rewolucyjnego" wiązało się z gruntowną modernizacją kraju. Najważniejsze do zrealizowania zadania odnosiły się do sprzeciwu wobec hegemonizmu i utrzymania pokoju, reunifikacji kraju oraz programu czterech modernizacji. To ostatnie zastąpiono obowiązującymi do dziś określeniami gaige - „reforma” oraz kaifang - „otwarcie na świat". Strategie pokojowego wzrostu (2003 r.) i pokojowego rozwoju (2004 r.) podkreślały, że rosnące w siłę Chiny mają wyłącznie pokojowe zamiary, a promowana od $2006 \mathrm{r}$. koncepcja harmonijnego świata zakładała oparcie globalnego porządku na zasadzie multilateralnego podejmowania decyzji, współpracy między państwami w ramach obustronnych korzyści (zasada win-win) oraz dążenie do równowagi sił. Odrodzenie wielkości chińskiej nacji i przywrócenie Chinom należnego miejsca jako światowego mocarstwa w społeczności międzynarodowej od wielu lat jest podstawowym dążeniem przywódców, elit rządzących i społeczeństwa chińskiego. Potwierdzono to w „wielkiej strategii Chin”, w której okres do 2020 r. i dalej aż do połowy XXI w. określany jest mianem "czasu strategicznej szansy". Założenia przyjęte w dokumencie przewidują osiągnięcie czterech głównych celów rozwojowych odnoszących się do: długookresowego, stałego i zrównoważonego wzrostu 
gospodarczego, potwierdzenie statusu mocarstwa, osiągnięcie średniego poziomu dobrobytu i podniesienie międzynarodowej zdolności konkurencyjnej państwa. Warto w tym miejscu zwrócić uwagę, że używane w Chinach zarówno w układzie wewnętrznym, jak i zewnętrznym pojęcia pokojowego wzrostu i pokojowego rozwoju, zaczęto uzupełniać, szczególnie od 2012 r., terminem rozwój naukowy, co ma uświadomić społeczności międzynarodowej, że Chiny nie kierują się w stosunkach multilateralnych przesłankami czy uprzedzeniami ideologicznymi, lecz prowadzą swoją politykę rozwoju w oparciu o najnowsze badania naukowe. Równocześnie nie mają one żadnych rewizjonistycznych zamiarów i nie chcą zmieniać istniejącego porządku w świecie, podtrzymując zasadę pokojowego współistnienia i preferując politykę nieingerencji w sprawy wewnętrzne innych państw.

Przeobrażenia cywilizacyjne dokonane w Chinach oraz ich kierunki rozwoju prezentuje niniejsza monografia. Rozpoczyna ją M. Przech ciekawym artykułem pt. Główne kierunki polityki zagranicznej Chińskiej Republiki Ludowej w świetle konferencji prasowej ministra spraw zagranicznych ChRL Wang Yi w dniu 8 marca 2018 r. Kontynuacja i nowe akcenty. M. Wróblewski analizuje Strategiczne partnerstwo chińsko-rosyjskie w sektorze energetycznym 2014-2019. Natomiast R. Podgórzańska w artykule Polityka Chińskiej Republiki Ludowej wobec Batkanów Zachodnich prezentuje analizę kierunków oddziaływania Chin na państwa bałkańskie. W podobnej narracji naukowej jest artykuł W. Gierszewskiej Obecność Chin w Rwandzie w sferze polityczno-gospodarczej. Zaś Kwestia Tybetu w stosunkach czesko-chińskich to treść artykułu M. Czyżniewskiego. M.M. Sztuka w części zatytułowanej Chińska decyzja administracyjna o ukaraniu - cechy językowe analizuje język i słownictwo używane w chińskich decyzjach administracyjnych o ukaraniu, wykorzystując przykłady za- 
czerpnięte z przebadanych dokumentów. Problemy kultury, sztuki filmowej, symboliki przekazu oraz dziedzictwo architektury chińskiej przedstawiają: I. Grodź - Zhang Yimou. Między prawda a iluzja...; Youyou Lu - Tradycyjne chińskie symbole w chińskiej sztuce wspótczesnej oraz K. Matuszczyk-Lu - Między tradycja a innowacja - chińska architektura wspótczesna. Z kolei H.J. Błazińska analizuje System nauczania w dawnych Chinach, a A. Gryszkiewicz w pracy Symbolika tańca w kole plemienia Amis podczas Święta Żniw w Yuli na Tajwanie bada rytuał taneczny nie tylko z perspektywy historycznej, ale także współczesnej w kontekście politycznym, ekonomicznym i społecznym. Na rzeczywistość powyborczą w Indonezji i Bhutanie zawracają uwagę w swoich artykułach $\mathrm{K}$. Bielawski - Indonezja po wyborach powszechnych $w 2019$ r: $w$ stronę rozwiazań nieliberalnych? i K. Sopolińska - Wybory parlamentarne w Bhutanie w latach 2008-2018.

Joanna Marszałek-Kawa Krzysztof Zamasz 
Marcin Przech

Uniwersytet Marii Curie-Skłodowskiej w Lublinie

\section{Główne kierunki polityki zagranicznej Chińskiej Republiki Ludowej w świetle konferencji prasowej ministra spraw zagranicznych ChRL Wang Yi w dniu 8 marca 2018 r. Kontynuacja i nowe akcenty}

\section{Wstęp}

Znaczenie międzynarodowe Chin i ich pozycja we współczesnym świecie powoduje zrozumiałe zainteresowanie polityką zagraniczną tego wielkiego państwa. Jednym za sposobów informowania o niej są konferencje prasowe szefa dyplomacji Chińskiej Republiki Ludowej, ministra spraw zagranicznych Wang Yi.

W dniach od 5 marca do 20 marca 2018 r. odbyła się w Pekinie pierwsza sesja parlamentu, XIII Ogólnochińskiego Zgromadzenia Przedstawicieli Ludowych. W czasie jej trwania, 8 marca, minister spraw zagranicznych ChRL Wang Yi spotkał się z krajowymi i zagranicznymi dziennikarzami na konferencji prasowej. Odpowiadając na pytania dziennikarzy, nakreślił główne kierunki polityki zagranicznej Chin, odniósł się do wielu konkretnych problemów stojących obecnie przed chińską dyplomacją. Biorąc pod uwagę jego pięcioletni staż na stanowisku ministra spraw zagranicznych oraz dodatkowy awans na ważne stanowisko radcy stanu do spraw kontaktów międzynarodowych, uzyskany 19 marca, treści przekazane przez ministra Wang Yi są wyrazem stanowiska najwyższych władz Chin 
w sprawach międzynarodowych. Analiza ich, porównanie z dotychczasowymi pryncypiami polityki zagranicznej, kierunkami i zasadami działania chińskiej dyplomacji, a także dostrzeżenie nowych akcentów, spowodowanych zapewne zmieniającą się sytuacją geopolityczną może wnieść wiele do poznania i zrozumienia działań Chińskiej Republiki Ludowej na płaszczyźnie stosunków międzynarodowych.

\section{Treść konferencji prasowej}

Konferencja prasowa trwała dwie godziny i wzięło w niej udział prawie 600 chińskich i zagranicznych dziennikarzy. Odstępując od relacji zgodnej z kolejnością pytań i odpowiedzi, można podzielić kwestie omówione przez ministra Wanga Yi pod względem typu podmiotu, którego relacje z Chinami były omawiane. W ten sposób podzielono treść konferencji na pięć działów odnoszących się kolejno do:

- chińskiej agendy dyplomatycznej na ;2018 r.

- stosunków Chin na szczeblu międzypaństwowym;

- stosunków Chin z organizacjami ponadnarodowymi;

- Inicjatywy Pasa i Drogi (BRI);

- nowych trendów w polityce zagranicznej CHRL.

\section{Chińska agenda dyplomatyczna na 2018 r.}

W 2018 r., wdrażając decyzje XIX Zjazdu KPCh, odzwierciedlające myśl polityczną przewodniczącego Xi Jinpinga, określającą ustrój Chin jako „socjalizm nowej ery z chińską specyfiką”, Chiny będą w 2018 r. gospodarzem czterech ważnych wydarzeń:

1 State Council, People's Republic of China, Xi's report to the 19th CPC National Congress published, http://english.gov.cn/news/top_news/2017/ 10/28/content_281475923975224.htm [dostęp: 28.10.2017]. 
- w kwietniu odbędzie się konferencja „Forum for Asia” w Bo'ao na Hajnanie, w 40. rocznicę rozpoczęcia reform i otwarcia Chin na świat zewnętrzny, stanowiąca przegląd doświadczeń Chin i nowych możliwości reform i współpracy azjatyckiej;

- w czerwcu będzie miał miejsce w Qingdao, w prowincji Shandong, szczyt Szanghajskiej Organizacji Współpracy poświęcony rewitalizacji ducha organizacji;

- we wrześniu odbędzie się w Pekinie Forum Chiny-Afryka, które będzie poświęcone Inicjatywie Pasa i Drogi. Stanowić będzie ono, jak określił minister, wielką szansę dla Afryki na pełne uczestnictwo w BRI - Inicjatywie Pasa i Drogi;

- w listopadzie w Szanghaju odbędą się pierwsze międzynarodowe targi dotyczące wyłącznie importu do Chin, China International Import Expo.

\section{Relacje Chin na szczeblu międzypaństwowym}

Pytania dziennikarzy, skupiające się na stosunkach Chin z pojedynczym państwem, dotyczyły pięciu krajów: obu Korei, Japonii, Stanów Zjednoczonych, Indii, a ponadto szczególnych relacji z Tajwanem, uznawanym przez rząd w Pekinie za jedną z prowincji Chin.

Wang Yi zwrócił uwagę na wymierne efekty chińskich propozycji „zawieszenie za zawieszenie”, które owocowały zawieszeniem prób nuklearnych i rakietowych przez KRLD i zawieszeniem przez USA i Koreę Południową wspólnych ćwiczeń wojskowych. Wskazał, że Chiny w pełni pochwalają i popierają wysiłki obu Korei. Wezwał on USA i KRLD do szybkiego zaangażowania się w dialog dotyczący denuklearyzacji Półwyspu Koreańskiego. Jak zauważył, „trudno jest roztopić nagroma- 
dzone lody. Wszystkie strony muszą wykazać odwagę polityczną, by osiągnąć porozumienie"2. Należy dodać, że niezwykle dynamiczny rozwój sytuacji od marca do maja 2018 r. wskazuje na skuteczność środków chińskiej dyplomacji.

Odpowiadając na pytanie przedstawiciela japońskiej agencji Kyodo, Wang Yi powiedział, że Chiny z zadowoleniem przyjmują bardziej pozytywną politykę Japonii wobec Chin. Przypomniał on, że czterdzieści lat temu Chiny i Japonia podpisały traktat pokojowy. Wyraził nadzieję, że Japonia pogodzi się z rozwojem potęgi Chin i zyska, jak ujął, „polityczną wiarygodność" podejmując odpowiednie działania, aby stworzyć warunki dla politycznego rozumienia, że „Chiny i Japonia postrzegają się wzajemnie jako partnerzy, a nie zagrożenie"3.

Chiny i USA zgadzają się, że łączą je szerokie interesy i ważna odpowiedzialność za globalny pokój, stabilność i dobrobyt. Oba państwa powinny prowadzić szeroko zakrojoną współpracę opartą na obopólnych korzyściach, zarządzać różnicami w oparciu o wzajemny szacunek, pogłębiać wzajemne zrozumienie i przyjaźn między obywatelami oraz pracować na rzecz trwałego, zdrowego i stałego rozwoju stosunków. Współpraca, zdaniem Wanga Yi, jest pożądanym sposobem rozwoju stosunków chińsko-amerykańskich. Według najnowszego sondażu Gallupa, ponad 50\% Amerykanów ma korzystny pogląd na Chiy i jest to najwyższy wskaźnik od prawie trzech dekad. Minister Wang Yi uznał, że gdy Chiny i Stany Zjednoczone będą współpracować, przyniosą korzyści nie tylko własnym krajom, ale także całemu światu. Jeśli istnieje między nimi konkuren-

2 Ministry of Foreign Affairs of the People's Republic of China, Foreign Minister Wang Yi meets the Press 8.03.2018, https://www.fmprc.gov.cn/ mfa_eng/wjb_663304/wjbz_663308/2461_663310/t1540928.shtml [dostęp: 9.05.2018].

3 Ministry of Foreign Affairs of the People's Republic of China, Foreign..., op.cit. 
cja, to musi być zdrowa i pozytywna, „nie musimy być rywalami, powinniśmy starać się być partnerami”" Minister powiedział, że Chiny są zdeterminowane, aby pozostać na wybranej przez siebie drodze postępu, a rozwój i rewitalizacja Chin są nie do powstrzymania. Zdaniem Wanga Yi Amerykanie twierdzą, że Chiny chcą zastąpić rolę Ameryki jako głównego supermocarstwa na świecie. Uznał ten wniosek za zasadniczo błędny, twierdząc, że Chiny znajdują się na „ścieżce socjalizmu o charakterystycznych chińskich cechach". Jest to sytuacja korzystna dla wszystkich, „win-win”, im bardziej Chiny się rozwijają, tym większy wkład w rozwój świata mogą wnieść. Chiny i Stany Zjednoczone muszą się szanować, dążyć do współpracy opartej na obopólnych korzyściach, typu „win-win”. Zauważył, że wojna handlowa nigdy nie jest właściwym rozwiązaniem, gdyż zaszkodzi zarówno inicjatorowi, jak i państwu będącemu celem. Ostrzegł, że Chiny podejmą uzasadnioną i konieczną reakcję. Interesy Chin i Stanów Zjednoczonych są głęboko splecione. Odwołując się do interesu społeczności globalnej, Wang Yi powiedział: „Musimy mieć na uwadze nie tylko interesy naszego narodu, ale także dobro świata"

Na dziesięć dni przed wyborami prezydenckimi w Federacji Rosyjskiej Chiny wsparły kandydaturę W. Putina. Chwaląc dotychczasowe relacje Wang Yi stwierdził, że „kompleksowe partnerstwo koordynacyjne Chiny-Rosja jest tak samo nie-

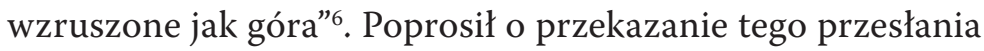
rosyjskim partnerom $\mathrm{w}$ tradycyjny chiński, poetycki sposób, ujmując sytuację: „niebo jest tylko granicą dla chińsko-rosyjskiej współpracy”, co znaczyło deklarację braku ograniczeń $\mathrm{w}$ tej sferze.

\footnotetext{
4 Ibidem.

5 Ibidem.

6 Ibidem.
} 
Pytany o trudny rok w stosunkach między Indiami a Chinami, Wang Yi uznał, że mimo trudności relacje między Chinami a Indiami poprawiają się. Zauważył, że przywódcy Chin i Indii opracowali strategiczną wizję przyszłości stosunków: chiński „smok” i indyjski „słoń” nie mogą ze sobą walczyć, ale powinny tańczyć ze sobą. Równie poetycko ujął zjawisko synergii, mającej tu zastosowanie, mówiąc, że w takim przypadku jeden plus jeden będzie równy nie tylko dwóm, ale także jedenastu. Chiny i Indie muszą zrobić wszystko, aby wspierać się. „Nawet Himalaje nie powstrzymają nas przed wzmocnieniem przyjaźni” - powiedział. „Chiny są chętne i gotowe do kontynuowania tradycyjnej przyjaźni oraz bycia przyjacielem i partnerem Indii. Zastąpmy podejrzenia zaufaniem, zarządzajmy różnicami poprzez dialog i budujmy przyszłość poprzez współpracę"8. Miało to szczególny wydźwięk w świetle niedawnego konfliktu granicznego między oboma państwami.

Wang Yi przypomniał, pytany o decyzję Gambii, a także Wysp Świętego Tomasza i Książęcej oraz Panamy o zerwaniu stosunków dyplomatycznych z Tajwanem, a nawiązaniu ich z władzami w Pekinie, że obie strony są zgodne, że na świecie są tylko jedne Chiny, a Tajwan jest nieodłączną częścią Chin (fundamentalna zasada "jednych Chin", yige Zhongguo). Wang Yi powiedział, że brak oficjalnych związków z Tajwanem stał się ogólnie przyjętą normą w stosunkach międzynarodowych. Uznał, że jest to oczywiście właściwy wybór zgodny z falą historii, by nawiązywać stosunki dyplomatyczne i prowadzić regularną współpracę z rządem Chińskiej Republiki Ludowej, jedynym prawnym przedstawicielem całych Chin. Stwierdził, że taki wybór najlepiej służy interesom zainteresowanych państw

$\begin{array}{ll}7 & \text { Ibidem. } \\ 8 & \text { Ibidem. }\end{array}$ 
i narodów. Podkreślił też, że władze Tajwanu powinny powrócić do konsensusu z 1992 r. tak szybko, jak jest to możliwe.

\section{Relacje Chin z organizacjami międzynarodowymi i regionami}

Pytany, czy Francja może nadać nowy kierunek stosunkom Chiny-Unia Europejska, Wang Yi wyraził nadzieję, że Francja wniesie istotny wkład w promowanie współpracy między Chinami i UE. Przypomniał prezydenta Emmanuela Macrona, który złożył wizytę państwową w Chinach, wizytę premier Theresy May. Przyznał też, że istnieją również pewne różnice zdań między Chinami a Unią Europejską. Wang Yi podkreślił, że Chiny popierają integrację europejską i ufają w przyszłość Europy. Biorąc pod uwagę całą niepewność w globalnej sytuacji międzynarodowej, Chiny, zdaniem władz w Pekinie, są gotowe współpracować z Europą.

Przypominając piętnastą rocznicę strategicznego partnerstwa między Chinami a ASEAN, stwierdzono, że współpraca Chiny-ASEAN jest przykładem najbardziej udanej i dynamicznej w regionie Azji i Pacyfiku. Proponowana wizja partnerstwa strategicznego między Chinami a ASEAN i planowana jej realizacja do 2030 r. doprowadzi do lepszej koordynacji między Inicjatywą Pasa i Drogi (Belt and Road Initiative, BRI) a planami rozwojowymi ASEAN. Zostaną podjęte wysiłki w celu zbudowania pasa rozwoju gospodarczego Lancang-Mekong. Wang Yi przypomniał, że od dziewięciu lat z rzędu Chiny są największym partnerem handlowym ASEAN. W ubiegłym roku obroty w handlu z ASEAN przekroczyły 500 mld dolarów.

Mówiąc o jednym z najtrudniejszych zagadnień polityki zagranicznej swego rządu Wang Yi powiedział, że jeśli chodzi o utrzymanie pokoju i stabilności na Morzu Południowochiń- 
skim determinacja Chin jest bardzo silna, a zaangażowanie jest głębokie. Podejście Chin do kwestii Morza Południowochińskiego jest zdaniem ministra odpowiedzialne i uwzględnia interesy narodu chińskiego, fakty historyczne, imperatyw pokoju w regionie i prawo międzynarodowe. Sytuacja na Morzu Południowochińskim zmienia się w jego mniemaniu na lepsze, a Chiny i państwa ASEAN stoją przed wielką szansą, by opracować kodeks postępowania na Morzu Południowochińskim, dla zachowania pokoju w akwenie, jak i w całym regionie. Wang Yi zauważył, że Chiny i państwa ASEAN są skłonne i zdolne do samodzielnego opracowywania przepisów regionalnych, które spełnią wymogi tego regionu i będą przestrzegane przez wszystkich. Na Morzu Południowochińskim również istnieją wyzwania. Wang Yi określił tę sytuację jako działanie sił zewnętrznych, które „nie są zadowolone z panującego spokoju i próbują wzniecać kłopoty i zmącić wody. Ich częsta demonstracja siły w pełni uzbrojonych samolotów i okrętów jest najbardziej destabilizującym czynnikiem dla pokoju i stabilności w naszym regionie" . Przypomniał chińskie powiedzenie: „Zielone wzgórza nie mogą powstrzymać płynącej rzeki, aż do rozległego oceanu, która posuwa się naprzód"10. Wang Yi zapewnił, że Chiny będą współpracować z państwami ASEAN, aby wykorzystać szansę, poszerzyć współpracę, zapobiegać obcej ingerencji i stawić czoła wyzwaniom. Zapowiedział też, że Chiny i państwa ASEAN przyspieszą konsultacje i będą promować pokój i współpracę na Morzu Południowochińskim.

Odpowiadając na pytanie jaki jest pogląd Chin na "strategię Indo-Pacyfiku" realizowaną przez Stany Zjednoczone, Japonię, Indie i Australię i czy jest to próba „powstrzymania” Chin, Wang Yi powiedział, że wbrew temu, co twierdzą niektórzy

\footnotetext{
9 Ibidem.
}

10 Ibidem. 
naukowcy i media, że „strategia Indo-Pacyfiku” właśnie ma na celu powstrzymanie Chin, choć oficjalne stanowisko czterech państw jest przeciwne, zdaniem chińskich władz ta inicjatywa nie ma na celu konkretnego państwa. Minister zastrzegł, że podsycanie nowej zimnej wojny jest przykładem anachronicznego myślenia i nie znajdzie chętnych do realizacji.

Gdy jeden z dziennikarzy zaproszonych na konferencję prasową przypomniał, że jedenaście państw podpisze w bieżącym dniu umowę nowej formy Partnerstwa Transpacyficznego (CPTPP), minister Wang Yi poinformował, że Chiny nie są stroną CPTPP. Chiny są jednak zdecydowanym zwolennikiem liberalizacji handlu, będąc kluczowym podmiotem współpracy gospodarczej w regionie Azji i Pacyfiku. W 2014 r. Chiny przekonały władze państw APEC do rozpoczęcia w Pekinie procesu ustanowienia strefy wolnego handlu w regionie Azji i Pacyfiku. Chiny pozytywnie oceniają wszelkie otwarte, przejrzyste i kompleksowe ustalenia, które wzmacniają globalny system wolnego handlu czy to RCEP, czy CPTPP. „Mamy nadzieję na lepszą komunikację, koordynację i interakcję między różnymi inicjatywami wolnego handlu w naszym regionie"11 - powiedział Wang Yi.

Zdaniem szefa chińskiej dyplomacji Chiny i państwami Ameryki Łacińskiej pomagają sobie i wspierają się nawzajem jako kraje rozwijające się. Zastrzegł on, że ta współpraca nie ma na celu zastąpić nikogo w jakiejkolwiek roli. Współpraca Chin regionem Ameryki Łacińskiej szybko się rozwinęła, ponieważ odpowiada jego potrzebom, poprawia warunki życia mieszkańców regionu i zwiększa zdolność do samodzielnego rozwoju tych państw. Wang Yi przypomniał, że w ciągu ostatnich pięciu lat przewodniczący Xi Jinping trzykrotnie odwiedził Amerykę Łacińską i Karaiby, składając wizyty w dziesięciu państwach regionu. Inwestorzy chińscy stworzyli tam ponad

11 Ibidem. 
1,8 mln lokalnych miejsc pracy, przyczyniając się do zmniejszenia bezrobocia.

Odnosząc się do sztandarowego projektu władz chińskich, Wang Yi wyjaśnił, że BRI jest przejrzystą inicjatywą zainicjowaną przez Chiny. Wyjaśnił, że wynika to ze „złotej zasady” szeroko zakrojonych konsultacji, wspólnego wkładu i wspólnych korzyści. Współpraca w zakresie Pasa i Drogi ma na celu jego zdaniem zapewnienie równych szans, integracji i korzyści dla wszystkich. Planowanie i wdrażanie projektów BRI zostało omówione przez uczestników przy zachowaniu równoprawności zdań. Żaden kraj nie dominuje w tym procesie, wszystkie strony mają równy głos. Do tej pory ponad osiemdziesiąt państw i organizacji międzynarodowych podpisało umowy BRI z Chinami, a wiele projektów BRI jest już w toku realizacji. Chiny budują kilkanaście elektrowni w Pakistanie, z których największa dostarcza energię elektryczną dziesiątkom milionów Pakistańczyków. W Serbii chińskie przedsiębiorstwo kupiło nierentowną hutę stali, przywracając jej prawidłowe funkcjonowanie. W Grecji chińska grupa przejęła operację największego portu Pireus, powiększając jego możliwości do poziomu największych portów Europy. Chiny współpracują w sektorze energetycznym z Francją, a także w budowie elektrowni atomowej w Wielkiej Brytanii. Minister zwrócił uwagę, że realizacja programu BRI odbywa się z poszanowaniem reguł międzynarodowych. Jako platforma współpracy międzynarodowej w naturalny sposób BRI kieruje się zasadami rynkowymi. Inicjatywa ta jest otwarta na pomysły uczestników, prowadzące do korzyści zarówno dla reszty świata, jak i Chin.

\section{Nowe trendy w polityce zagranicznej CHRL}

Przedstawiciel chińskiego dziennika, „China Daily”, zadał pytanie czy Chiny porzuciły swoją długoletnią politykę nieinge- 
rencji na rzecz bardziej interwencjonistycznego podejścia. Czy jest to nowy trend w polityce zagranicznej Chin? Wang Yi odpowiedział, że jako stały członek Rady Bezpieczeństwa ONZ Chiny poważnie traktują swoją odpowiedzialność za utrzymanie międzynarodowego pokoju. Dziś Chiny są w znacznie lepszej sytuacji, aby pomóc w rozwiązaniu różnych problemów regionalnych i międzynarodowych. „Jesteśmy gotowi, aby odegrać naszą rolę", w rzeczywistości świat oczekuje od Chin nie mniej. Podejście Chin jest jednocześnie przy tym pokojowe, dobrze uzasadnione i konstruktywne.

Po pierwsze, Chiny preferują polityczne rozstrzyganie sporów przez dialog i negocjacje oraz zdecydowanie odrzucają użycie siły.

Po drugie, ChRL szanuje suwerenność i interesy innych krajów i nigdy nie wtrąca się w ich wewnętrzne sprawy.

Po trzecie, Chiny dokładają wszelkich starań, aby być uczciwym i obiektywnym uczestnikiem stosunków międzynarodowych. Podejście Chin do polityki zagranicznej jest zakorzenione w tradycyjnej kulturze chińskiej, zgodnie z celami i zasadami Karty Narodów Zjednoczonych.

Na sugestię dziennikarza, że Chiny niekiedy bywają postrzegane jako zagrożenie, Wang Yi odparł, że od dziesięcioleci Zachód dokonywał różnego rodzaju ocen i prognoz dotyczących Chin. Dla niektórych ludzi Zachodu Chiny albo „upadają”, albo „zagrażają". Wraz z rozwojem Chin pierwsza teoria się zdezaktualizowała. Tymczasem zwolennicy drugiej teorii, zdaniem ministra, wyczarowują nową wersję. Chiny włożyły swój wkład w ponad 70\% redukcji ubóstwa na całym świecie, co jest, jak nazwał, cudem w historii ludzkości. Mając najliczniejszy udział w siłach pokojowych ONZ wśród stałych członków Rady Bezpieczeństwa i drugi największy wkład w budżet pokojowy ONZ, Chiny ponoszą ważną odpowiedzialność za utrzymanie pokoju na świecie. Nie wspominając już o tym, że w ciągu ostatnich pię- 
ciu lat, wraz z m.in. Inicjatywą Pasa i Drogi Chiny wysunęły się na czoło w promocji globalnego zarządzania, wolnego handlu i otwartej gospodarki światowej. Nie mając uprzedzeń ani nie praktykując podwójnych standardów, nie da się nie zauważyć, że Chiny stanowią nie zagrożenie, ale mnóstwo możliwości. Teoria o chińskim zagrożeniu, zaznaczył Wang Yi, nie ma oparcia w faktach. Pytany, co Ministerstwo Spraw Zagranicznych zrobi w 2018 r., aby ułatwić realizację chińskich celów rozwojowych Wang Yi powiedział, że Chiny wciąż są państwem rozwijającym się, a ułatwianie rozwoju wewnętrznego kraju jest nieodłączną częścią dyplomacji chińskiej. Mając na uwadze nową misję stojącą przed Państwem Środka i to, czego się od niego oczekuje, Chiny dostosują się do nowych realiów rozwoju, zarówno udziału w globalizacji, jak i rozwoju wewnętrznego. Zamierzają zmierzyć się z nowymi wyzwaniami stojącymi przed chińskim społeczeństwem. Zainicjowana będzie nową serię inicjatyw i reform, zapowiedział. Władze ChRL nadal będą w pełni angażować się w walkę z ubóstwem i przyczynią się do wygrania ogólnokrajowej kampanii wykorzenienia tego zjawiska. Wang Yi zapowiedział, że chińskie możliwości dyplomatyczne na całym świecie zostaną użyte do ułatwienia realizacji Inicjatywy Pasa i Drogi oraz ochrony zagranicznych interesów Chin. W polityce zagranicznej jako współczesne mocarstwo o „chińskiej specyfice", jak określił minister, w nowych czasach, Chiny chcą być nie tylko pionierem chińskiego zaangażowania na arenie międzynarodowej, ale także chcą, by ta polityka przyczyniała się do rozwoju wewnętrznego Chin.

Minister Wang Yi zapowiedział też, że zaangażowane i odpowiedzialne Chiny przyjmą bardziej aktywną politykę zagraniczną. W swoim raporcie na XIX Zjeździe Komunistycznej Partii Chin sekretarz generalny Xi Jinping podkreślił, że KPCh będzie dążyć zarówno do dobrobytu Chińczyków, jak i do postępu ludzkości. Zaangażowane i odpowiedzialne Chiny 
przyjmą bardziej wizjonerską politykę zagranicznąa ${ }^{12}$. Zapewniając sprzyjające warunki dla własnego rozwoju, Chiny będą w stanie zbudować globalną wspólnotę dla wspólnej przyszłości. Wizją Chin jest ukształtowanie nowego rodzaju stosunków międzynarodowych, które cechuje wzajemny szacunek, sprawiedliwość i współpraca z obopólnymi korzyściami oraz budowanie otwartego, globalnego, czystego i pięknego świata, który cieszy się trwałym pokojem, powszechnym bezpieczeństwem i wspólnym dobrobytem. Wang Yi powiedział, że Chiny będą bronić równości wszystkich państw, dużych i małych, będą szanować różne cywilizacje i systemy, przedłożą większe dobra ogólnoludzkie przed własnym interesem i „przeciwstawią się praktyce zastraszania przez wielkiego i silnego małych i słabych". Chiny staną w obronie słabszych państw i pomogą mniej rozwiniętym krajom osiągnąć wzrost gospodarczy. Odgrywając bardziej aktywną rolę w światowej polityce Chiny będą dążyć do spełnienia rosnących oczekiwań ze strony środowiska międzynarodowego. Chiny będą bardziej aktywnie pomagać w reformowaniu i ulepszaniu globalnego systemu zarządzania, rozwiązywania problemów regionalnych i międzynarodowych za pomocą środków politycznych i wspólnego rozwiązywania problemów i wyzwań stojących przed światem. Powołując się na starożytnego chińskiego klasyka, piszącego, że „kiedy sprawiedliwość zwycięży, świat stanie się jedną społecznością”, Wang Yi wyraził przekonanie, że Chiny zdecydowane są podtrzymywać suwerenność i godność kraju. „Chiny są zdeterminowane, aby stanąć po stronie międzynarodowej sprawiedliwości i postępu ludzkości, aby budować pokój na świecie, przyczyniać się do globalnego dobrobytu i podtrzymywać porządek międzynarodowy"13.

12 State Council, People's Republic of China, Xi's report..., op.cit.

13 Ministry of Foreign Affairs of the People's Republic of China, Foreign..., op.cit. 
Na pytanie o rolę i wpływ na dyplomację osoby prezydenta Xi Jinpinga Wang Yi wyjaśnił, że osobista dyplomacja głowy państwa ma niezastąpioną wartość strategiczną. Przypomniał, że od 2012 r. przewodniczący Xi Jinping jest głównym architektem charakterystycznej chińskiej dyplomacji i do chwili obecnej odwiedził 57 krajów i przyjął ponad 110 zagranicznych szefów państw. Te ważne wizyty i spotkania przyczyniają się do pogłębienia światowego zrozumienia Chin, wzmocnienia profilu i wpływów Chin oraz ułatwienia rozwiązania wielu globalnych problemów. W nadchodzącym roku przewodniczący Xi Jinping będzie gospodarzem czterech wydarzeń dyplomatycznych uczestnicząc w szczycie BRICS w Republice Południowej Afryki, spotkaniu przywódców ekonomicznych APEC w Papui Nowej Gwinei i szczycie G20 w Argentynie. „Wierzymy, że osobista dyplomacja przewodniczącego Xi wniesie pozytywny i odpowiedzialny wkład w dobrobyt jego ludu, interesy Chin i dobrobyt świata"14.

\section{Podsumowanie}

Treści przekazane przez ministra spraw zagranicznych Chin na konferencji prasowej w dniu 8 marca 2018 r. potwierdzają dążenie i gotowość Chin do odgrywania roli „wielkiego, odpowiedzialnego państwa" (you zeren de daguo $)^{15}$. Zmodernizowane i wzmocnione sukcesami gospodarczymi Chiny zapowiadaja ustami szefa dyplomacji prowadzenie asertywnej polityki zagranicznej, odpowiadającej ich znaczeniu w dzisiejszym świecie i pozycji w stosunkach międzynarodowych. Pośród odpowiedzi na pytania dziennikarzy można zauważyć z jednej strony twarde i jasne trzymanie się dotychczasowych pryncypiów chińskiej

\footnotetext{
14 Ibidem.

15 J.P. Cabestan, Polityka zagraniczna Chin, Warszawa 2013, s. 367.
} 
polityki zagranicznej, jak zasada jednych Chin (yige Zhongguo), pretendowanie do roli przywódcy i swoistego opiekuna państw rozwijających się czy traktowanie Morza Południowochińskiego jako swoistego mare nostrum, a z drugiej strony pojawienie się nowych akcentów w relacjach z najważniejszymi uczestnikami stosunków międzynarodowych. Wyraźnym i znaczącym elementem konferencji było też pytanie i następnie odpowiedź ministra dotycząca roli osobistej dyplomacji głowy państwa, prezydenta Xi Jinpinga w tworzeniu polityki zagranicznej Chin i jego wysiłków dyplomatycznych. Podkreśla to wzmocnienie władzy Xi Jinpinga, a także coraz większe uwypuklanie roli przywódcy piątej generacji władz chińskich w kierowaniu państwem, niespotykane u jego poprzedników od czasów „Wielkiego Sternika” Mao Zedonga. Organizacja czterech ważnych wydarzeń międzynarodowych w 2018 r. podkreśla aktywną rolę Chin w życiu gospodarczym świata. Najważniejszym chyba elementem konferencji była odpowiedź na pytanie dziennikarza z „China Daily”, dotyczącego zmiany dotychczasowej polityki nieingerencji na rzecz bardziej asertywnego podejścia, jak nazwał, bardziej interwencjonistycznego. Długa odpowiedź Wanga Yi stanowi podsumowanie nowej polityki zagranicznej Chin, podkreślając fundamenty ideologiczne, zasadę rozwiązywania sporów za pomocą dialogu i konsensusu, odrzucenia użycia siły, równouprawnienie wszystkich członków wspólnoty międzynarodowej, poszanowanie suwerenności innych państw, odrzucenie ingerencji w sprawy wewnętrzne państw słabszych przez państwa silniejsze czy podkreślenie obowiązku wzięcia współodpowiedzialności za pokój, rozwój oraz dobrobyt na świecie przez nowe, bogatsze i silniejsze Chiny. Odrzucając tezę o „chińskim zagrożeniu”, proponując w zamian swoistą "chińską nadzieją i szansę dla świata”, globalny odpowiednik popularnego obecnie określenia „chińskiego snu”, parafrazy „American dream” w odniesieniu do rozwoju Chin i budowy społeczeństwa dobrobytu w, jak określo- 
no, „socjalizmie współczesnej ery z chińską specyfikę" ${ }^{\text {.16. Wizja }}$ świata „Czystego, otwartego i pięknego" ${ }^{17}$, w którym stosunki międzynarodowe będą oparte na zasadach równości, poszanowania odrębności, wspólnych korzyści, zaś pozbawione będą dominacji mocnych nad słabymi, świata rozwoju, dobrobytu i pokoju, strzeżonego przez aktywniejsze politycznie i rozwinięte Chiny jest tym obrazem, jaki władze chińskie ustami szefa dyplomacji chciały pokazać uczestnikom konferencji prasowej w dniu 8 marca. Kwestią przyszłości jest, w jaki sposób i na ile zgodnie z zasadami zaprezentowanymi na konferencji Chińska Republika Ludowa, bezsprzecznie „supermocarstwo wschodzące" prowadzić będzie swoją dalszą politykę zagraniczną, a sposób jej prowadzenia z pewnością będzie miał wielki wpływ na sytuację międzynarodową na świecie.

\section{Bibliografia}

Alison G., Skazani na wojnę?, Warszawa 2018.

Cabestan J.P., Polityka zagraniczna Chin, Warszawa 2013.

Góralczyk B., Wielki Renesans. Chińska transformacja i jej konsekwencje, Warszawa 2018.

Haliżak E., Stosunki międzynarodowe w regionie Azji i Pacyfiku, Warszawa 1999.

Leonard M., What does China think?, London 2008.

Ministry of Foreign Affairs of the People's Republic of China, Foreign Minister Wang Yi meets the Press 8.03.2018, https:// www.fmprc.gov.cn/mfa_eng/wjb_663304/wjbz_663308/ 2461_663310/t1540928.shtml.

16 State Council, People's Republic of China, Xi's report..., op.cit.

17 Ministry of Foreign Affairs of the People's Republic of China, Foreign..., op.cit. 
Qian Qichen, Waijiao Shiji (Dziesięć historii dyplomatycznych), Beijing 2003.

Shirk S., China: Fragile Superpower, Oxford 2007.

State Council, People's Republic of China, Xi's report to the 19th CPC National Congress published, http://english.gov. cn/news/top_news/2017/10/28/content_281475923975224. htm.

Xi Jinping, Chińskie Marzenie, Warszawa 2018.

Xi Jinping, Innowacyjne Chiny, Warszawa 2015.

Xi Jinping, The Governance of China, Beijing 2014.

\begin{abstract}
Abstrakt
W dniach od 5 marca do 20 marca 2018 r. odbyła się w Pekinie pierwsza sesja chińskiego parlamentu, XIII Ogólnochińskiego Zgromadzenia Przedstawicieli Ludowych. W czasie jej trwania, 8 marca, minister spraw zagranicznych ChRL Wang Yi spotkał się z krajowymi i zagranicznymi dziennikarzami na konferencji prasowej. Odpowiadając na pytania dziennikarzy, nakreślił główne kierunki polityki zagranicznej Chin, odniósł się do wielu konkretnych problemów stojących obecnie przed chińską dyplomacją. Biorąc pod uwagę jego pięcioletni staż na stanowisku ministra spraw zagranicznych oraz dodatkowy awans na ważne stanowisko radcy stanu do spraw kontaktów międzynarodowych, uzyskany 19 marca, treści przekazane przez ministra Wanga Yi są wyrazem stanowiska najwyższych władz Chin w sprawach międzynarodowych. Analiza ich, porównanie z dotychczasowymi pryncypiami polityki zagranicznej, kierunkami i zasadami działania chińskiej dyplomacji, a także dostrzeżenie nowych akcentów, spowodowanych zapewne zmieniającą się sytuacją geopolityczną może wnieść wiele do poznania i zrozumienia działań Chińskiej Republiki Ludowej na płaszczyźnie stosunków międzynarodowych.
\end{abstract}

Słowa kluczowe: Chiny, Chińska Republika Ludowa, Xi Jinping, Wang Yi, Inicjatywa Pasa i Drogi, BRI, chińska dyplomacja 


\begin{abstract}
From March 5, 2018 to March 20, the first session of parliament, the Thirteenth General Assembly of People's Representatives, was held in Beijing. During the meeting, on March 8, the Foreign Minister of the PRC, Wang Yi, met with domestic and foreign journalists at a press conference. Answering questions from journalists, he outlined the main directions of China's foreign policy, he referred to many specific problems currently facing Chinese diplomacy. Considering his five-year term as Minister of Foreign Affairs, and an additional promotion to the important position of the state adviser on international relations, designed on March 19, the content provided by Minister Wang Yi is an expression of China's top international leadership. Analyzing them, comparing with the current principles of foreign policy, directions and principles of Chinese diplomacy, as well as seeing new accents, emerging probably due to the changing geopolitical situation, can explain and facilitate understanding of the actions of the People's Republic of China on the level of international relations.
\end{abstract}

Keywords: China, People's Republic of China, Xi Jinping, Wang Yi, foreign policy of China, Belt and Road, BRI 


\section{Mateusz Wróblewski}

Uniwersytet Warszawski

ORCID ID: https://orcid.org/0000-0002-0095-6761

\section{Strategiczne partnerstwo chińsko-rosyjskie w sektorze energetycznym 2014-2019}

Chińska Republika Ludowa oraz Federacja Rosyjska odgrywają kluczową rolę w zróżnicowaniu kierunków handlu w zakresie surowców energetycznych. Chiny chcą przede wszystkim uniezależnić się od państw Zatoki, które praktycznie mają monopol na dostawy surowców do ChRL. Ma to jednocześnie na celu pozbycie się zagrożenia odcięcia morskiego przez siły trzecie i zatrzymania rozwoju gospodarki. Zatem utworzenie bezpiecznych linii przesyłowych jest celem samym w sobie. Rosja nadaje się do tego jak żaden inny kraj, gdyż leży przy północnych granicach, w całkiem innym obszarze niż pozostali partnerzy. Posiada silną armię, która zabezpiecza państwo przed interwencją z zewnątrz, co zapewnia spokój dla długotrwałego rozwoju biznesu. Rosja, oprócz naturalnej chęci zarobku, chce przede wszystkim zbudować swoją „drugą nogę”, w kwestii eksportu surowców energetycznych. W rezultacie sankcji nałożonych przez Unię Europejską, sprawa ta stała się szczególnie ważka, gdyż bez zapewnienia sobie dużego drugiego rynku zbytu, Rosja nie posiada pola manewru. Trzecią kwestią jest potencjalny zysk z całego rynku wschodnio-azjatyckiego. Eksperci szacują, że rynek ten będzie potrzebował znacznie więcej surowców, niż ten europejski ${ }^{1}$.

1 N. Sharushkin, Russia Targets More Downstream Capacity in Consumer Markets, „International Oil Daily”, 4.04.2006. 
Kooperacja na polu energetycznym rozpoczęła się już w 2001 r. Ta pierwsza inicjatywa została jednak wyjątkowo nawiązana między państwowym CNPC ze strony chińskiej, a prywatnym Jukosem ze strony rosyjskiej. Wspólne przedsięwzięcie miało doprowadzić do przesyłu ropy naftowej ze złóż wschodniosyberyjskich do północnych Chin (Angarsk-Daqing). Jednak na przeszkodzie temu projektowi stanęła kontrpropozycja państwowej rosyjskiej firmy Transnieft, która postanowiła zbudować rurociąg z Angarska do wybrzeży Oceanu Spokojnego ${ }^{2}$. Rurociąg ten został ochrzczony imieniem ESPO (East Siberia-Pacific Ocean). Zasadniczo oba szlaki szły po tej samej trasie z rozgałęzieniem w mieście Skovorodino, gdzie wersja Jukosu skręcała na południe w stronę granicy rosyjskochińskiej. W wyniku rozgrywek politycznych w Rosji, Jukos znalazł się w rękach państwowych. Nieoczekiwanie jednak, po wielu latach negocjacji, w 2009 r. ten właśnie pierwotny projekt tego podmiotu został wdrożony. Kontrakt między stronami doprowadził do zainwestowania 25 mld dolarów w zamian za ropę. Przez dwadzieścia lat Rosnieft zobowiązał się do dostarczenia $30 \mathrm{mln}$ ton surowca ${ }^{3}$. W pięć lat później Transnieft uzyskał pozwolenie na podwojenie przepustowości ESPO. Było to spowodowane znaczącym wzrostem na rynku azjatyckim, który na tamten moment pochłaniał 25\% całego eksportu rosyjskiej ropy naftowej ${ }^{4}$. Obecne dane za 2017 r. wskazują, że Federacja Rosyjska została największym dostawcą ropy naftowej dla Chińskiej Republiki Ludowej, prześcigając Arabię Saudyjską, poprzez dostarczenie 5,67 mln ton ropy naftowej ${ }^{5}$. Na ten wynik składają

2 J. Bellacqua, The Future of China-Russia Relations, Lexington 2010, s. 152.

3 M. Sussex, R.E. Kanet (red.), Russia, Eurasia and the New Geopolitics of Energy. Confrontation and Consolidation, Nowy Jork 2015, s. 156.

4 Ibidem.

5 Russia remains China's top oil supplier as pipeline expands, 24.02.2018, 
się dostawy poprzez dwa ropociągi ESPO, port Koźmino oraz pośrednie dostawy poprzez ropociągi z Kazachstanu. Dodatkowo, zdając sobie sprawę z potrzeby zagranicznych inwestycji kapitałowych, Rosja stara się przyciągać nowych chińskich inwestorów na Syberię. Owocem promocji złóż naftowych jest zakup udziałów w polu naftowym Wankor przez CNPC czy też porozumienie dotyczące wspólnej eksploatacji złóż wschodniej Syberii - Russkoje oraz Jurubczeno-Tochomskoje ${ }^{6}$. Poprzez te zakupy i inwestycje Chiny liczą na zwiększenie internacjonalizacji juana, gdyż coraz więcej transakcji między nimi a Rosją jest prowadzonych w walutach narodowych ${ }^{7}$.

Współpraca w dziedzinie dostaw gazu jest natomiast nieco innym tematem. Gazprom, jako monopolista w eksporcie gazu, podpisał w 2014 r. umowę dotyczącą dostaw tego surowca do ChRL, opiewającą na kwotę 400 mld dolarów amerykańskich. Umowa ta została jednak podpisana po długich negocjacjach dotyczących ceny. Jest to spowodowane stosunkowo małym zapotrzebowaniem Chin na import. Jednakowoż, dla wzmocnienia swojego bezpieczeństwa energetycznego, wypromowanie waluty oraz zacieśnienia więzi z Rosją, konsorcjum CNPC postanowiło zainwestować w projekt 20 mld dolarów amerykań-

https://www.reuters.com/article/us-china-economy-trade-crude/russiaremains-chinas-top-oil-supplier-as-pipeline-expands-idUSKCN1G808M [dostęp: 2.02.2020].

6 M. Kaczmarski, S. Kardaś, „Naftowa przyjaźn’”: stan i perspektywy rosyjsko-chińskiej wspótpracy energetycznej, 17.02.2016, https://www.osw.waw. $\mathrm{pl} / \mathrm{pl} /$ publikacje/komentarze-osw/2016-02-17/naftowa-przyjazn-stan-i-perspektywy-rosyjsko-chinskiej [dostęp: 2.02.2020]; R. Miśkiewicz, Organisational Structure in the Process of Integration on the Example of Iron and Steel Industry Enterprises in Poland. Process digitisation in the Industry 4.0 concept, Warszawa 2019, s. 71.

7 V. Spivak, Why a Russia-China currency swap agreement turned out to be a damp squib, 25.04.2017, „RBTH”, https://www.rbth.com/business/2017/04/25/why-russia-china-currency-swap-agreement-turned-dampsquib-750321 [dostęp: 2.02.2020]. 
skich $^{8}$. Rurociąg Siła Syberii rozpoczyna się na wschodniosyberyjskim polu gazowym Kovutka. Projekt ten, liczący 4 tys. km rurociągu, infrastrukturę oraz zaangażowanie tysięcy ludzi, pozwoli nie tylko zdywersyfikować przychody Gazpromu, ale też rozwinie niedoinwestowane tereny Syberii Wschodniej ${ }^{9}$. Drugim ważnym projektem jest gazociąg Altai, który ma połączyć zachodniosyberyjskie złoża z prowincją Xinjiang. Umowa ramowa została podpisana w kwestii budowy również jak w przypadku Siły Syberii w $2014 \mathrm{r} .^{10}$ Pozwoli to na zaopatrzenie w gaz zachodnich Chin i zabezpieczenie potencjalnych dostaw do dalekich południowowschodnich prowincji, podłączonych do wielkich chińskich sieci przesyłowych. Stronie rosyjskiej pozwoli to natomiast na skierowanie części gazu ze złoża nakierowanego na europejski rynek, na rynek azjatycki.

Pozostaje jeszcze kwestia Arktyki, w której zasadniczą rolę odgrywa technologia LNG, mogąca pozwolić na szersze upowszechnienie tego typu gazu w kontraktach między podmiotami rosyjskimi a zagranicznymi. Jednak kwestia ta wykracza poza obszar energetyki.

\section{Współpraca chińsko-rosyjska w obszarze Arktyki}

Jedną z ciekawszych kwestii w stosunkach między Państwem Środka a Federacją Rosyjską jest współpraca w obszarze Arktyki. Jest to jedna z najnowszych płaszczyzn współpracy, bo rozpoczęta za przewodnictwa Xi Jinpinga. Głównym powodem zwrotu jest naturalnie zmiana klimatu na Ziemi, który doprowadza

8 M. Sussex, R.E. Kanet (red.), Russia, Eurasia and the New Geopolitics of Energy. Confrontation and Consolidation, Nowy Jork 2015, s. 157.

9 Informacje z oficjalnej strony Gazpromexportu, http://www.gazpromexport.ru/en/projects/3/ [dostęp: 2.02.2020].

10 Infografika dotycząca gazociągu Altai, http://tass.com/infographics/7251 [dostęp: 2.02.2020]. 
do rozmarzania biegunów. Doprowadzi to do utworzenia Północnej Drogi Morskiej, która skróci czas podróżowania z Azji do Europy z pięciu do trzech tygodni w stosunku do przejścia przez Suez ${ }^{11}$. To sprawia, że pojawiają się całkowicie nowe możliwości wykorzystania tych obszarów, co naturalnie zainteresowało państwa.

W 2013 r. rosyjska firma Novatek podpisała z chińskim CNPC umowę dotyczącą zakupu 20\% wyprodukowanego skroplonego gazu z projektu Jamal LNG. Co więcej, w wyniku sankcji nałożonych na rosyjskie podmioty Chińczycy postanowili przyjść w sukurs temu projektowi. Wobec ciągłego braku kapitału akcje w projekcie zakupił za kwotę 1 mld dolarów Fundusz Jedwabnego Szlaku. W 2016 r. chińskie banki zainwestowały dalsze 12 mld dolarów. Obie inwestycje zapewniły $60 \%$ niezbędnych projektowi funduszy ${ }^{12}$. Co więcej, Chińczycy przysłali swoich inżynierów, aby pomóc w budowie niezbędnej infrastruktury. To bardzo silne zaangażowanie strony chińskiej w projekt wynika z kilku faktów. Pierwszym z nich jest promowanie „Nowego Jedwabnego Szlaku”. Projekt jamalski był pierwszą dużą inwestycją nowo powstałego Funduszu Jedwabnego Szlaku. Sukces tego przedsięwzięcia dodał prestiżu tak wewnętrznie, jak zewnętrznie całej inicjatywie. Drugą sprawą jest gospodarka chińska. Następuje przejście z ciepłownictwa węglowego do gazowo-ekologicznego. Do 2030 r. Chiny szacunkowo mają posiadać zapotrzebowanie na gaz w wysokości 620 mld metrów sześciennych. Jest to ponad dwa razy więcej

11 I. Johnston, Sail from Britain to Japan in 20 days thanks to global Warming, „The Independent”, 4.05.2017, https://www.independent.co.uk/ environment/arctic-sea-ice-melting-shipping-routes-china-japan-europenorth-america-a7718201.html [dostęp: 2.02.2020].

12 C.T.N. Sørensen, E. Klimenko, Emerging Chinese Russian cooperation in the Arctic Possibilities and constraints, „SIPRI Policy Paper” 2017, nr 46, s. 32 . 
niż obecnie ${ }^{13}$. Dla Rosji oczywiście cała inwestycja jest nastawiona przede wszystkim na zysk, lecz wobec wystąpienia zachodnich sankcji nabiera znaczenia jako symbol przetrwania bez dostępu do kapitału oraz technologii z państw Zachodu.

Kolejną płaszczyzną współpracy jest rozbudowa infrastruktury transportowej. W ramach budowy Północnej Drogi Transportowej Chińczycy chcą zainwestować w nowy głęboki port w Archangielsku oraz w Bielkomorską Linię Kolejową, która skróci o setki kilometrów trasę dostawczą z Syberii ${ }^{14}$. Pieniądze dane przez chińskie banki oraz Chinese Poly Technologies Incorporated są oczywiście ukierunkowane na tę inwestycję ze względu na jej użyteczność względem projektu Jedwabnego Szlaku. Pojawia się tu jednak przeszkoda w postaci niechęci rządu rosyjskiego do inwestycji w ten projekt. Ze słów rosyjskiego ministra transportu można wnioskować, że bliższym terminem realizacji przedsięwzięcia jest dopiero następna dekada. Z brakiem zaufania mamy również do czynienia w sprawie żeglugi. Rosja niechętnie podchodzi do kooperacji w dziedzinie przepływu przez północne wody statków państw innej niż swoja bandery.

\section{Forum Energetyczne Chiny-Rosja 2018 w Pekinie}

Jednym z bardziej znaczących wydarzeń w relacjach energetycznych między państwami było Forum Energetyczne Chiny-Rosja 2018 w Pekinie. Ważnym wydarzeniem tego pierwsze-

13 N Filimonova, S. Krivokhizh, China's Stakes in the Russian Arctic, „The Diplomat”, 18.01.2018, https://thediplomat.com/2018/01/chinasstakes-in-the-russian-arctic/ [dostęp: 2.02.2020].

14 T. Nilsen, Railway, port on agenda for China's Vice Premier in Arkhangelsk, „The Barents Observer”, 27.03.2017, https://thebarentsobserver.com/ en/industry-and-energy/2017/03/railway-port-agenda-chinas-vice-premierarkhangelsk [dostęp: 2.02.2020]. 
go forum było niewątpliwie wystąpienie jednego z najważniejszych polityków Kremla - Igora Sechina. W swoim wystąpieniu Igor Sechin (CEO Rosnieftu, które jest największym dostawcą ropy naftowej) zauważył znaczny postęp w rozwoju stosunków między Rosją a Chinami w ciągu ostatnich dziesięciu lat. $\mathrm{Na}$ przykład w ciągu ostatniej dekady obroty towarowe między państwami wzrosły ponad 2,5 razy: z 40 mld dolarów w 2007 r. do 110 mld dolarów oczekiwanych do końca bieżącego roku. W tym czasie podwojenie dostaw paliw i produktów energetycznych z Rosji do Chin spowodowało, że Rosja stała się największym dostawcą energii do ChRL. W ciągu ostatnich dziesięciu lat ponad $300 \mathrm{mln}$ ton ropy, $55 \mathrm{mln}$ ton produktów ropopochodnych, $150 \mathrm{mln}$ ton węgla i 20 mld kilowatogodzin energii elektrycznej zostało wysłanych do chińskich konsumentów ${ }^{15}$.

Nie obyłoby się to jednak bez licznych kredytów przyznawanych przez stronę chińską rosyjskim kontrahentom. Jak przyznał sam Sechin: „Współpraca energetyczna przyczyniła się do rozszerzenia relacji w innych obszarach. Stosunki handlowe wykroczyły poza dostawy energii. Widzimy synergię: usługi chińskich banków zyskują popularność; istnieje możliwość stworzenia pionowo zintegrowanych łańcuchów; mamy perspektywy wspólnej pracy na nadchodzących rynkach innych krajów"16.

Właśnie na tej konferencji można było dostrzec istotę wzajemnych relacji, która w okresie rzadów Xi Jinpinga jak się wydaje ostatecznie się wyklarowała. Federacja Rosyjska wobec braku kapitału wewnętrznego i sankcjom nałożonym przez państwa Unii Europejskiej oraz Stanów Zjednoczonych Ameryki musi poszukiwać inwestycji zagranicznych z państw Azjatyckich. Największe możliwości kredytowe dysponują w tym

15 https://www.rosneft.com/press/today/item/193103/ [dostęp: 2.02.2020].

16 Ibidem; R. Miśkiewicz, The importance of knowledge transfer on the energy market, „Polityka Energetyczna” 2018, vol. 21 (2), s. 1-14. 
rejonie banki chińskie. Ponadto samo państwo chińskie jest zainteresowane takimi inwestycjami ze względu na niechęć do pozostawiania pieniędzy w bezruchu, a co za tym idzie nie przynoszą one żadnych korzyści. Co więcej, dzięki kredytowaniu inwestycji w sektorze energetycznym Federacji Rosyjskiej, ChRL zmniejsza swoją zależność od dostaw surowców energetycznych drogą morską przez Ciesninę Malakka (80\% zapotrzebowania), która jest kontrolowana przez siły co najmniej neutralnie negatywnie nastawione do rządu w Pekinie. Dzięki zabezpieczeniu dostaw drogą lądową, zwiększa się pole manewru polityki zagranicznej Chin w regionie Azji.

\section{Polityka cenowa i perspektywy na przyszłość}

Kontrowersje budzi jednak sama polityka cenowa prowadzona przez Gazprom względem CNPC czy szerzej Chińskiej Republiki Ludowej. Wynegocjowana cena 350-380\$ za tysiąc metrów sześciennych gazu wydaje się bardzo ryzykowna dla strony rosyjskiej ${ }^{17}$. O ile w systemie europejskim pozwala ona na duży zwrot, o tyle ze względu na trudne warunki atmosferyczne oraz odległości, może ona się okazać za niska. Szczególnie jeśli weźmiemy pod uwagę, że całość kontraktu rozkłada się na trzydzieści lat. Minusem dla Rosji jest na pewno przejęcie przez Chińczyków 19\% akcji Gazpromu. Pozwoli im to na wgląd w działania tej firmy, jak również wpływania na jej decyzje. Co więcej, transakcje mają być rozliczane w chińskim juanie, co wymusza na Rosji dbanie o jak najlepszą kondycję tej waluty.

Umowa ta może być rozpatrywana jako zwycięstwo Rosji pod względem wzmocnienia rozwoju Dalekiego Wschodu. Dzięki podpisanej umowie uda się dostarczyć gaz do wielu rosyjskich

17 https://www.reuters.com/article/us-china-russia-gas/as-putinlooks-east-china-and-russia-sign-400-billion-gas-deal-idUSBREA4K07 K20140521 [dostęp: 2.02.2020]. 
miast. Ponadto pojawią się nowe miejsca pracy związane z obsługą infrastruktury przesyłowej. Udało się również osiągnąć dywersyfikacje dostaw gazowych, tak potrzebną po rozpoczęciu się zawirowań na Ukrainie i następujących po nich sankcjach.

Kolejnym niewątpliwym plusem dla Rosji będzie zwiększenie jej obecności na rynkach Dalekiego Wschodu. Szczególnie interesująca wydaje się perspektywa możliwości przesyłania gazu do państw takich jak Japonia czy Korea Południowa.

\section{Podsumowanie}

Obecny stan stosunków energetycznych między Chińską Republiką Ludową a Federacją Rosyjską skłania do jasnej konkluzji: wzajemne relacje będą ulegać ciągłemu pogłębieniu ze względu na żywotne interesy stron. Tak Rosja, jak i Chiny potrzebują siebie nawzajem. Co więcej, odkrywają nowe możliwości współpracy z roku na rok. Ponadto swego rodzaju rywalizacja ze światem zachodnim wpycha oba państwa we wzajemne objęcia, tworząc oś przeciwwagi. Same perspektywy są też ogromne jak zasoby surowców energetycznych kryjących się na Syberii i w Arktyce. Syberia będzie wykorzystywana w sposób klasyczny, dostarczając gazociągami i ropociągami surowce do ChRL. Jednak to Arktyka z trudno dostępnymi pokładami surowców wydaje się miejscem, gdzie rozkwitnie współpraca między dwoma stronami. Będzie ona potrzebna przede wszystkim w dziedzinie innowacyjnych nowych technologii, które pozwolą na wydobycie cennych surowców spod tafli lodu i zimnego morza. Co do samej polityki cen można być pewnym, że dopóki Rosja będzie znajdować się pod zachodnimi sankcjami, dopóty Chiny będą mogły dyktować ceny. Summa summarum, tak smok, jak i niedźwiedź są na siebie skazani w najbliższej dekadzie. 


\section{Bibliografia}

Bellacqua J., The Future of China-Russia Relations, Lexington 2010.

http://tass.com/infographics/7251.

http://www.gazpromexport.ru/en/projects/3/.

https://thebarentsobserver.com/en/industry-and-energy/

2017/03/railway-port-agenda-chinas-vice-premier-arkhang elsk.

https://thediplomat.com/2018/01/chinas-stakes-in-the-russian-arctic/.

https://www.independent.co.uk/environment/arctic-sea-icemelting-shipping-routes-china-japan-europe-north-america-a7718201.html.

https://www.osw.waw.pl/pl/publikacje/komentarze-osw/201602-17/naftowa-przyjazn-stan-i-perspektywy-rosyjsko-chin skiej.

https://www.rbth.com/business/2017/04/25/why-russia-china-currency-swap-agreement-turned-damp-squib-750321. https://www.reuters.com/article/us-china-economy-tradecrude/russia-remains-chinas-top-oil-supplier-as-pipelineexpands-idUSKCN1G808M.

https://www.reuters.com/article/us-china-russia-gas/as-putin-looks-east-china-and-russia-sign-400-billion-gas-dealidUSBREA4K07K20140521.

https://www.rosneft.com/press/today/item/193103/.

Sharushkin N., Russia Targets More Downstream Capacity in Consumer Markets, International Oil Daily, 4.04.2006.

Sørensen C.T.N., Klimenko E., Emerging Chinese Russian cooperation in the Arctic Possibilities and constraints, „SIPRI Policy Paper" 2017, nr 46.

Sussex M., Kanet R.E., Russia, Eurasia and the New Geopolitics of Energy. Confrontation and Consolidation, New York 2015. 


\begin{abstract}
Abstrakt
Artykuł analizuje relacje energetyczne między Federacją Rosyjską a Chińską Republiką Ludową. Skupia się na okresie 2014-2019, kiedy to nabrały one nowej dynamiki, spowodowanej pogorszeniem się relacji stron z zachodnimi partnerami. Wzajemna współpraca ma zatem charakter pragmatyczny, podyktowany korzyściami, jakie obie strony uzyskują w kwestiach polityczno-gospodarczych.. Sztandarowym projektem jest realizowany wspólnie gazociąg „Siła Syberii”, który ma pozwolić na dywersyfikację przesyłów gazowych dla obydwu partnerów. Rosja uzyskuje kolejny rynek zbytu, który pozwoli na zrekompensowanie strat poniesionych w wyniku coraz twardszej polityki państw członkowskich Unii Europejskiej. Chiny natomiast uzyskują stabilny dostęp do dostaw surowcowych drogą lądową. Ważną kwestią pozostaje również współpraca na obszarze Arktyki. Jest ona umotywowana otwieraniem się tej północnej drogi morskiej ze względu na rozmarzanie obszaru. Wobec sankcji nałożonych na Rosję Chiny stanowią ważny element umożliwiający dalszą eksploatację surowców energetycznych.
\end{abstract}

Słowa kluczowe: Federacja Rosyjska, Chińska Republika Ludowa, energetyka

\begin{abstract}
The article analyzes energy relations between the Russian Federation and the People's Republic of China. It focuses on the period 2014-2019 when they gained new dynamics, caused by the deterioration of the relations of the parties with Western partners. Mutual cooperation is therefore pragmatic, dictated by the benefits that both sides obtain in political and economic matters. The flagship project is the jointly implemented "Strength of Siberia" gas pipeline, which is to allow diversification of gas flows for both partners. Russia is gaining another market, which will make it possible to compensate for the losses suffered as a result of the increasingly tough policy of the European Union Member States. China, on the other hand, has stable access to raw material supplies by land. Cooperation in the Arctic also remains an important issue. It is motivated by the opening of this northern sea route due to the thawing of the area. In view of the sanctions imposed on Russia, China is an important element enabling the further exploitation of energy resources.
\end{abstract}

Keywords: Russian Federation, People's Republic of China, energy 


\section{Renata Podgórzańska}

Uniwersytet Szczeciński

ORCID ID: https://orcid.org/0000-0001-6610-9699

\section{Polityka Chińskiej Republiki Ludowej wobec Bałkanów Zachodnich}

\section{Wprowadzenie}

Współcześnie jednym z istotnych czynników kształtujących porządek europejski i oddziałującym na relacje dwustronne i wielostronne jest rosnący wpływ Chińskiej Republiki Ludowej, którego odzwierciedlenie stanowi systematyczny wzrost politycznego i gospodarczego zaangażowania tego państwa w Europie. Jest to konsekwencją trwających od kilkudziesięciu lat zmian w sferze gospodarczej skutkujących zwiększaniem potencjału gospodarczego Chin, a tym samym umocnieniem się ich pozycji w układzie międzynarodowym ${ }^{1}$. Niezależnie od braku akceptacji dla praktyki politycznej w Chinach, osiągnięta wskutek systematycznie wprowadzanych reform pozycja w wymiarze międzynarodowym jest niepodważalna. Chiny, z mało znaczącego, izolującego się i zacofanego gospodarczo państwa przeradzają się do roli lidera nie tylko gospodarki azjatyckiej, ale coraz silniej oddziałującym w skali globalnej². Przeobrażenie gospodarki centralnie planowej w gospodarkę zorientowa-

1 Zob. B. Góralczyk, Geostrategia Xi Jinpinga - Chiny ruszaja w świat, „Rocznik Strategiczny” 2016/2017, s. 286-300.

2 R. Podgórzańska, Wspótpraca państw Grupy Wyszehradzkiej z Chińska Republiką Ludowa. Możliwości i ograniczenia, [w:] Wspótpraca i rywalizacja państw azjatyckich, red. J. Marszałek-Kawa, J. Zajączkowski, Toruń 2018, s. 201-211. 
ną na rynek, przy zachowaniu - co należy wyraźnie podkreślić - szczególnego udziału państwa pozwoliło Chinom osiągnacć pozycję wicelidera w gospodarce światowej ${ }^{3}$. Przy czym, jak zauważa Katarzyna Żukrowska, Chiny po okresie dynamicznego wzrostu w latach 1970-2017 urosły do miana największej gospodarki świata i choć stosowane wskaźniki „wielkości” budzą wedle przywołanej Autorki wiele zastrzeżeń, to nie ulega wątpliwości, że państwo to dokonało „skoku rozwojowego”. Pomijając głębszą analizę czynników determinujących wzrost potencjału Chin, jednakowoż uznając ich wielonurtowy i zmieniający się w czasie charakter dostrzec należy systematyczny awans tego państwa do grona światowych liderów ${ }^{5}$.

Kontynuując rozważania należy podkreślić, iż obserwowany w ostatnich latach wzrost aktywności Chin wobec Bałkanów Zachodnich stanowi konsekwencję przyjętych założeń chińskiej polityki zagranicznej6. Równocześnie podkreślenia wymaga fakt, iż ekspansja Chin będąc podporządkowaną zdefiniowanym strategicznym interesom politycznym i gospodarczym ma charakter wielokierunkowy. Wzmacniając swoją pozycję w układzie globalnym Chiny starają się zintensyfikować swe możliwości

3 J. Łapiński, Monitoring NSI wybranych krajów, [w:] Monitoring trendów krajowych i światowych 2019. Raport 6, red. P. Chaber, Warszawa 2019, s. 46.

4 K. Żukrowska, Chiny: potencjat (gospodarczy, polityczny i militarny) jako instrument kształtowania nowego układu międzynarodowego, „Krakowskie Studia Małopolskie" 2018, nr 1, s. 25.

5 Maciej Walkowski zalicza do nich m.in. filozoficzno-religijny system konfucjanizmu wsparty elementami taoizmu, umiejętność twórczego korzystania z dorobku innych gospodarek (naśladownictwo uczciwe lub nieuczciwe) pragmatyczne, dalekowzroczne, strategiczne i naukowe myślenie o rozwoju kraju, a także umiejętność stopniowej, spokojnej realizacji celów. Zob. M. Walkowski, Chiński model rozwoju społeczno-gospodarczego i jego potencjalna adaptacja w Europie, „Rocznik Strategiczny” 2017, nr 10, s. 344.

6 R. Koszyk, Kraje Europy Środkowo-Wschodniej wobec ekspansji chińskiej gospodarki, „Prace Komisji Geografii Przemysłu Polskiego Towarzystwa Geograficznego" 2016, nr 1, s. 180-183. 
wpływu na różne państwa i regiony posługując się przy tym szerokim instrumentarium oddziaływania. Przywołując pogląd Jakuba Potulskiego, że Chiny posiadając "potrójną osobowość” wynikającą z faktu, iż wciąż są państwem rozwijającym się, a zarazem mocarstwem wschodzącym i globalną potęgą mogą dowolnie pozycjonować się w środowisku międzynarodowym, dobierając partnerów i angażując się w kierunkach, które z ich punktu widzenia wspomagają realizację interesu narodowego ${ }^{7}$. Nie przeceniając roli Bałkanów Zachodnich z perspektywy Chin i chińskiej strategii obecności w Europie celem artykułu jest analiza determinantów zaangażowania ChRL na Bałkanach Zachodnich, które niezależnie od różnicy potencjału postrzegając tę część kontynentu jako istotną z punktu widzenia realizacji jej strategii umacniania wpływów w Europie Środkowo-Wschodniej. Z tak sformułowanym celem głównym artykułu koresponduje zamiar scharakteryzowania sposobów oddziaływania Chin na zachodniobałkańską rzeczywistość.

Potrzeba uporządkowania narracji, a przede wszystkim dążenie do zrealizowania założeń badawczych towarzyszących analizie polityki Chińskiej Republiki Ludowej wobec Bałkanów Zachodnich wymaga egzegezy kluczowych kategorii.

Pierwszą jest pojęcie „regionu”. Pomijając głębszą analizę tegoż pojęcia w artykule przyjęto jako wiodącą powszechnie stosowaną definicję regionu, która wskazuje na jednorodny charakter określonego obszaru, odróżniający się od terenów przyległych określonymi cechami naturalnymi i nabytymi ${ }^{8}$. Pojęcie „region” odnosi się zatem do wydzielonego przestrzennie obszaru, złożonego z państw położonych w bezpośrednim są-

7 J. Potulski, Chińska polityka zagraniczna, [w:] Wyzwania gospodarcze i polityczne państw Dalekiego Wschodu, red. J. Marszałek-Kawa, G. Kądzielewski, K. Zamsza, Toruń 2018, s. 53; R. Miśkiewicz, Transparency in Knowledge Transfer Processes in an Enterprise, „Przegląd Organizacji” 2018, nr 8, s. 10.

8 M. Szymczak (red.), Stownik języka polskiego, t. III, Warszawa 1989, s. 34. 
siedztwie ${ }^{9}$. Drugą kategorią wymagająca egzegezy jest pojęcie „Europy Środkowo-Wschodnia”, trzecią zaś „Bałkany Zachodnie”. Analizując drugie z wyróżnionych pojęć należy zauważyć fakt występowania wielu zróżnicowanych podejść do jego wyodrębniania $^{10}$. Najszersza wykładnia, na którą wskazuje Zbigniew Lach, obejmuje: Finlandię, Estonię, Łotwę, Litwę, Polskę, Czechy, Słowację, Węgry, Austrię, Rumunię, Białoruś, Ukrainę, Mołdawię, Słowenię, Chorwację, Serbię, Bośnię i Hercegowinę, Czarnogórę, Macedonię, Albanię, Bułgarię oraz Grecję i Turcję. Natomiast najwęższa interpretacja zawęża Europę Środkowo-Wschodnią do Polski, Czech, Słowacji i Węgier ${ }^{11}$. W przypadku innych prób systematyzacji pojęcia Europy Środkowo-Wschodniej zalicza się do niego jedenaście państw posiadających cechy wspólne i zintegrowanych z sobą określonymi powiązaniami o politycznej, społecznej, gospodarczej, kulturowej naturze, a mianowicie Bułgarię, Chorwację, Czechy, Estonię, Litwę, Łotwę, Polskę, Rumunię, Słowację, Słowenię oraz Węgry ${ }^{12}$. Mając na uwadze różnorodność w sposobie zakreślania przestrzeni Europy Środkowo-Wschodniej przyjmuje się, że w skład tego regionu wchodzi przyjęte przez Autorkę rozumienie regionu jest jednym z możliwych. Przy czym o przyjęciu w artykule szerokiej wykładni zdecydował sposób postrzegania regionu z perspektywy Chin. Europa Środkowo-Wschodnia jest definiowana przez

9 M. Sirecka-Wołodko, Regionalizm w stosunkach międzynarodowych, [w:] Współczesne stosunki międzynarodowe, red. T. Łoś-Nowak, Wrocław 2008, s. 322.

10 E. Znamierowska-Rakk, Pojęcie i tożsamość Europy Środkowo-Wschodniej w historiografii makroregionu i opinii elit Zachodu, „Studia z Dziejów Rosji i Europy Środkowo-Wschodniej” 2010, nr XLV, s. 9-10.

11 Z. Lach, Analiza poziomu rozwoju społecznoekonomicznego i potęgi państw Europy Środkowo-Wschodniej, „Przegląd Geopolityczny. Geopolitical Review" 2014, nr 9, s. 32-33.

12 R. Podgórzańska, The migration crisis from the perspective of the Central and Eastern Europe. Challenges for regional security, „Yearbook” 2017, s. 88-89. 
stronę chińską jako grupa szesnastu państw obejmująca: Estonię, Łotwę, Litwę, Polskę, Czechy, Słowację, Węgry, Rumunię, Bułgarię, Słowenię, Chorwację, Serbię, Bośnię i Hercegowinę, Czarnogórę, Albanię i Macedonię Północną ${ }^{13}$.

Natomiast „Bałkany Zachodnie” to termin, którym od końca lat 90. XX w. posługuje się Unia Europejska, określając w ten sposób wyodrębniony ze względu na specyficzny zespół cech subregion obejmujący Albanię, Bośnię i Hercegowinę, Chorwację, Macedonię Północną, Czarnogórę, Serbię i Kosowo, wobec którego od lat prowadzi działania ukierunkowane na stabilizację i umacnianie bezpieczeństwa militarnego, ekonomicznego, społecznego przez sukcesywne i coraz ściślejsze powiązanie go ze wspólnotą europejską ${ }^{14}$.

Biorąc pod uwagę złożony charakter analizowanej kwestii artykuł nie ma na celu całościowej analizy problemu, koncentruje się jedynie na wybranych kwestiach postrzeganych jako istotne z punktu widzenia analizowanego zjawiska, a do nich należy egzegeza czynników determinujących zainteresowanie i zaangażowanie Chin w państwach Bałkanów Zachodnich oraz wskazanie sposobów oddziaływania na zachodniobałkańską rzeczywistość.

\section{Bałkany Zachodnie - specyfika subregionu i jego potencjal}

Subregion Bałkan Zachodnich tworzą państwa o zróżnicowanym pod względem politycznym, narodowościowym, religijnym, kulturowym, społeczno-gospodarczym charakterze. Każde z nich znajduje się na innym rozwoju społeczno-gospodarczego i każde zmaga się z innymi problemami o politycznej naturze,

13 M. Kaczmarski, Chiny - Europa Środkowo-Wschodnia: „16+1”widziane z Pekinu, „Komentarze OSW”, 15.04.2015, nr 166, s. 1.

14 R. Podgórzańska, Albania w procesie integracji z UE - stan i perspektywy akcesji, „Rocznik Integracji Europejskiej” 2018, nr 12, s. 209. 
które przesadzają o ich pozycji oraz znaczeniu z perspektywy stosunków międzynarodowych. Czynnikiem zespalającym są - co należy wyartykułować - podjęte działania na rzecz zbliżenia z Unią Europejską, które w przeważającym stopniu decydują o dynamice i charakterze zmian jakie zachodzą, zarówno w przestrzeni politycznej, jak i gospodarczej tych państw.

Współczesne oblicze państw subregionu Bałkan Zachodnich i problemy, z którymi się zmagają są następstwem wydarzeń jakie rozgrywały się na obszarze Socjalistycznej Federacyjnej Republiki Jugosławii zapoczątkowanych u progu lat 90. XX w. Dziś już niepodległe i suwerenne państwa, usiłujące budować swoją międzynarodową pozycję w dużym stopniu determinowane są wspomnianymi doświadczeniami. To konieczność przezwyciężenia problemów, które wiążą się z doświadczeniami wojny na obszarze b. Jugosławii stanowi czynnik przesądzający o skali przeobrażeń bałkańskiej rzeczywistości ${ }^{15}$. W przypadku Albanii o obecnym jej statusie i pozycji w Europie przesądzają z jednej strony doświadczenia represyjnego systemu sprawowania władzy, z drugiej zaś problemy towarzyszące zainicjowanej u progu lat 90. XX w. transformacji ustrojowej. Przy czym podkreślić należy silne sprzężenie komunistycznej przeszłości z tempem i dynamiką przeobrażeń społecznych, politycznych i gospodarczych $^{16}$. Pomimo zmian jakie nastąpiły w Albanii w ostatnich latach, podniesienia poziomu życia mieszkańców, obniżenia poziomu ubóstwa wciąż jest ona jednym z najuboższych państw europejskich, z trudem adaptującym się do wymogów jakie formułuje Unia Europejska, a dotyczących kwestii fundamentalnych $\mathrm{z}$ punktu widzenia procesu integracji ${ }^{17}$.

15 D. Serwer, Can the Balkans Join the West?, https://link.springer.com/ content/pdf/10.1007\%2F978-3-030-02173-3_6.pdf [dostęp: 25.11.2019].

16 Zob. szerzej: E. Biberaj, Albania In Transition: The Rocky Road To Democracy, London 1999.

17 Zob. Commission Staff Working Document Albania 2019 Report 
Równocześnie zauważyć należy, iż pozostałe państwa cechują się równie ograniczonymi zasobami wynikającymi z poziomu gospodarki, należą one bowiem do najsłabiej rozwiniętych państw europejskich (zob. tabela 1). Przy czym nie można pominąć pozytywnych zmian, jakie zachodzą w przestrzeni gospodarczej państw zachodniobałkańskich. Według danych Banku Światowego niezwykle korzystne zjawiska stały się ich udziałem w 2019 r., które umożliwiają poprawę kondycji gospodarczej regionu. Wskutek odnotowywanego wzrostu gospodarczego spadło bezrobocie w państwach regionu, nastąpił wzrost zatrudnienia wśród kobiet i młodzieży. Niestety niepokoi to, że wciąż mniej niż połowa osób w wieku produkcyjnym ma pracę (44\%), co więcej obawy budzą prognozy wskazujące na obniżenie wzrostu gospodarczego (prognozy wskazują na obniżenie poziomu wzrostu gospodarczego 3,9\% w 2018 r. do $3,2 \%$ w 2019 r.), co wydatnie osłabi zmiany, jakie zachodziły na zachodniobałkańskim rynku pracy ${ }^{18}$. Zarazem podkreślenia wymaga fakt znaczących dysproporcji pomiędzy państwami Bałkan Zachodnich. Nie jest to jednorodny organizm, państwa te różnią się pomiędzy sobą zarówno potencjałem demograficznym, jak i poziomem rozwoju gospodarczego, rynkiem pracy, skalą nierówności dochodów, intensywnością i głębią problemów społecznych ${ }^{19}$.

Accompanying the document Communication from the Commission to the European Parliament, the Council, the European Economic and Social Committee and the Committee of the Regions 2019 Communication on EU Enlargement Policy [COM(2019) 260 final], https://ec.europa.eu/neighbourhood-enlargement/sites/near/files/20190529-albania-report.pdf [dostęp: 25.11.2019].

18 Western Balkans Regular Economic Report No.16. Rising Uncertainties, http://documents.worldbank.org/curated/en/643781570478210132/ pdf/Rising-Uncertainties.pdf [dostęp: 25.11.2019].

19 Zob. A. Balcer, Kierunek Bałkany! Znaczenie i potencjat wspótpracy Polski z państwami Batkanów Zachodnich, https://cutt.ly/peBc9uR [dostęp: 25.11.2019]. 
Uwzględniając powyższe przesłanki możemy stwierdzić, że zasoby jakimi dysponują te państwa są ograniczone, a problemy z którymi się zmagają hamują ich rozwój społecznogospodarczy.

Tabela 1. Wskaźniki rozwoju społeczno-gospodarczego państw Bałkanów Zachodnich oraz Chin

\begin{tabular}{|c|c|c|c|c|c|}
\hline Albania & 2014 & 2015 & 2016 & 2017 & 2018 \\
\hline GDP per capita w euro & 3451 & 3563 & 3733 & 4023 & 4455 \\
\hline Wzrost GDP w \% & 1,8 & 2,2 & 3,4 & 3,8 & 4,0 \\
\hline Inflacja & 1,6 & 1,9 & 1,3 & 2,0 & 2,3 \\
\hline Bośnia i Hercegowina & 2014 & 2015 & 2016 & 2017 & 2018 \\
\hline GDP per capita $\mathrm{w}$ euro & 3910 & 4.132 & 4344 & 4586 & 4830 \\
\hline Wzrost GDP w \% & 1,2 & 3,1 & 3,2 & 3,0 & 3,2 \\
\hline Inflacja & $-0,9$ & $-1,0$ & $-1,1$ & 1,2 & 1,4 \\
\hline Czarnogóra & 2014 & 2015 & 2016 & 2017 & 2018 \\
\hline GDP per capita w euro & 5563 & 5874 & 6349 & 6797 & 7319 \\
\hline Wzrost GDP w \% & 1,8 & 3,4 & 2,9 & 4,3 & 3,7 \\
\hline Inflacja & $-0,7$ & 1,5 & $-0,3$ & 2,4 & 2,8 \\
\hline Macedonia Pln. & 2014 & 2015 & 2016 & 2017 & 2018 \\
\hline GDP per capita w euro & 4139 & 4381 & 4687 & 4846 & 5041 \\
\hline Wzrost GDP w \% & 3,6 & 3,9 & 2,9 & 0,0 & 1,6 \\
\hline Inflacja & $-0,3$ & $-0,3$ & $-0,2$ & 1,4 & 1,8 \\
\hline Kosowo & 2014 & 2015 & 2016 & 2017 & 2018 \\
\hline GDP per capita w euro & - & - & - & & - \\
\hline Wzrost GDP w \% & - & - & - & & - \\
\hline Inflacja & - & - & - & - & - \\
\hline Serbia & 2014 & 2015 & 2016 & 2017 & 2018 \\
\hline GDP per capita w euro & 4666 & 4720 & 4902 & 5224 & 5041 \\
\hline Wzrost GDP w \% & $-1,8$ & 0,8 & 2,8 & 1,9 & 4,0 \\
\hline Inflacja & 2,1 & 1,4 & 1,1 & 3,1 & 2,1 \\
\hline Chiny & 2014 & 2015 & 2016 & 2017 & 2018 \\
\hline GDP per capita w euro & 5797 & 7361 & 7332 & 7651 & 8157 \\
\hline Wzrost GDP w \% & 7,3 & 6,9 & 6,7 & 6,9 & 6,6 \\
\hline Inflacja & 2,0 & 1,4 & 2,0 & 1,6 & 2,2 \\
\hline
\end{tabular}

Źródło: Statistic, https://ec.europa.eu/trade/policy/countries-and-regions/ statistics/ [dostęp: 25.11.2019]. 
Tabela 2. Liczba ludności w państwach Bałkanów Zachodnich oraz Chinach w 2018 r. (w tys.)

\begin{tabular}{|l|c|r|r|r|c|c|c|}
\hline & Chiny & Czarnogóra & Macedonia Płn. & Albania & Serbia & BiH & Kosowo \\
\hline $\begin{array}{l}\text { Liczba } \\
\text { ogółem }\end{array}$ & 13927,30 & 622,35 & 2082,96 & 2866,38 & 6982,08 & 3323,93 & 1855,30 \\
\hline \% mężczyzn & 51,3 & 49,4 & 50 & 50,9 & 49 & 49 & - \\
\hline \% kobiet & 48,7 & 50,6 & 50 & 49,1 & 51 & 51 & - \\
\hline
\end{tabular}

Źródło: Population, total - China, https://data.worldbank.org/indicator $/$ SP.POP.TOTL?locations=CN\&most_recent_year_desc $=$ false [dostęp: 25.11.2019].

Dystans dzielący państwa zachodniobałkańskie jest - jak wspominano - pochodną zarówno procesu rozpadu b. Jugosławii i uwarunkowań towarzyszących usamodzielnianiu się tych państw b. Jugosławii, jak również problemów związanych z wdrażaniem reform politycznych i gospodarczych ${ }^{20}$. Podkreślić należy, iż państwa Bałkanów Zachodnich w różnym stopniu wprowadzały niezbędne zmiany, a ich tempo powiązane było z wymogami jakie formułowała Unia Europejska. Podkreślić wszak należy, iż w latach 90. XX w. uznano, iż jedynym sposobem na wzrost bezpieczeństwa i stabilizacji w tej części Europy jest jej powiązanie ze strukturami UE. W konsekwencji o dynamice zmian, jakie przez lata zachodziły w bałkańskiej rzeczywistości, decydowały dążenia do akcesji w struktury UE. Ta ostatnia charakter powiązań i stopień integracji państw regionu uzależniała od tempa i zakresu reform społecznych, politycznych oraz gospodarczych. Co więcej, zauważyć należy, iż to presja ze strony UE jest zasadniczą przesłanką determinującą zakres i charakter zmian, jakie zachodzą w państwach Bałkan Zachodnich. Pomimo systematycznej poprawy sytuacji w regionie, umacnianiu pokoju i bezpieczeństwa (Globalny Index Pokoju ${ }^{21}$ ), spadku

20 E. Bujwid-Kurek, Państwa o proweniencji jugosłowiańskiej w procesie rozszerzania Unii Europejskiej - refleksje politologiczne, „Politeja” 2018, nr 5, s. $5-15$.

21 Według danych opracowywanych przez Instytut Ekonomii i Pokoju ob- 
zagrożenia terrorystycznego (Globalny Index Terroryzmu ${ }^{22}$ ) niepokoją m.in. wciąż odnotowywane deficyty w zakresie demokratycznego sprawowania władzy, niewydolność administracji, poziom życia mieszkańców, skala i charakter przestępczości.

Jak zauważa Adam Balcer, znaczenie Bałkanów Zachodnich wynika nie z potencjału demograficznego czy gospodarczego poszczególnych państw, ale w głównej mierze z ich strategicznego położenia, potencjału niestabilności, struktury etniczno-religijnej oraz zaangażowania kluczowych aktorów międzynarodowych ${ }^{23}$. W tym przypadku mowa o silnym oddziaływaniu takich podmiotów, jak Chiny, Rosja, Turcja, które mając zróżnicowane interesy i zróżnicowaną strategię oddziaływania na region starają się zaznaczyć swoją pozycję na Bałkanach ${ }^{24}$. Wyróżnione państwa, każde determinowane innymi przesłankami, są obecne w przestrzeni politycznej i ekonomicznej Bałkan Zachodnich, rywalizując z UE o wpływy w regionie ${ }^{25}$.

razujących poziom stabilności i pokoju na świecie w 2019 r. spośród 163 analizowanych państw Bałkan Zachodnich Serbia znalazła się na 50. pozycji, Albania na 51., Macedonia Północna na 65., Czarnogóra na 67., Bośnia i Hercegowina na 81., a Kosowo na 86. Zob. Global Peace Index 2019, s. 9, http://visionofhumanity. org/app/uploads/2019/07/GPI-2019web.pdf [dostęp: 25.11.2019].

22 Na liście państw objętych terroryzmem państwa Bałkan Zachodnich znajdują się stosunkowo daleko. Dla przykładu opracowany w 2019 r. indeks państw z uwzględnieniem zagrożeniem atakami terrorystycznymi wskazuje, iż najbardziej zagrożone terroryzmem jest Kosowo, które znajduje się na 79. pozycji na 138 analizowanych. W dalszej kolejności znalazły się Bośnia i Hercegowina (88 pozycja), Czarnogóra (97), Albania (110), Macedonia (115), Serbia (123). Zob. Global Terrorism Index 2019, s. 9, http://visionofhumanity.org/app/uploads/2019/11/GTI-2019web.pdf [dostęp: 25.11.2019].

23 A. Balcer, Kierunek Bałkany! Znaczenie i potencjał..., op.cit.

24 P. Bukowski, Geopolityczne źródła potencjalnych konfliktów w zachodniej części Batkanów, „Przegląd Geopolityczny” 2018, nr 24, s. 87-100.

25 Por. M. Hake, A. Radzyner, Western Balkans: Growing economic ties with Turkey, Russia and China, https://helda.helsinki.fi/bof/bitstream/ handle/123456789/16048/bpb0119.pdf?sequence=1 [dostęp: 27.11.2019]; P. Stronski, A. Himes, Russia's Game in the Balkans, Carnegie Endowment for International Peace, https://euagenda.eu/upload/publications/untitled-203333-ea.pdf [dostęp: 27.11.2019]. 


\section{Bałkany Zachodnie z perspektywy chińskiej polityki zagranicznej - przesłanki aktywności}

Mając na uwadze aktywność Chin na arenie międzynarodowej $\mathrm{w}$ ostatnich latach (przede wszystkim w wymiarze ekonomicznym) można zaobserwować intensyfikację współpracy z państwami Bałkanów Zachodnich. Analizując przesłanki zaangażowania Chin w tej części Europy niemniej jednak należy pamiętać o tym, iż Chiny postrzegają państwa zachodniobałkańskie wyłącznie jako część większej całości, a nie odrębny region Europy. Z perspektywy Chin to Europa Środkowo-Wschodnia jest przedmiotem oddziaływania (i przez nią wiedzie droga do uzyskania dostępu do rynków UE), zaś państwa Bałkanów Zachodnich są jedynie jego elementem. Jednakowoż z racji poszukiwania sposobów zwiększenia szansy realizacji strategicznych chińskich projektów Bałkany Zachodnie zyskały tym samym na znaczeniu. Aktywność Chin - co należy podkreślić - jest w pierwszej kolejności pochodną dążenia do realizacji projektu tzw. Nowego Jedwabnego Szlaku ${ }^{26}$, stanowiącego nową oś współpracy Chin ze szczególnie wartościowym partnerem jakim jest Europa ${ }^{27}$.

26 Koncepcja ta nawiązuje do historycznego Jedwabnego Szlaku. Została po raz pierwszy zarysowana przez przewodniczącego Xi Jinpinga, jesienią 2013 r. w Kazachstanie. Inicjatywa w zasadzie została ukazana w dwóch wersjach: lądowego i morskiego Szlaku Jedwabnego. Projekt ten, a raczej geostrategiczna wizja, zwana w oryginale Yidai, yilu, przestawiana została najpierw jako One Belt, One Road (OBOR), a następnie - BRI (Belt and Road Initiative). Zob. szerzej na ten temat: B. Góralczyk, Polska na trasie chińskiego Jedwabnego Szlaku: szansa rozwojowa czy tylko wyzwanie?, http:// wz.uw.edu.pl/portaleFiles/6133-wydawnictwo-/nowa_polityka_strukturalna/Bogdan_J._Goralczyk.pdf [dostęp: 25.11.2019]; R. Jakimowicz, Nowy Jedwabny Szlak a wzrost pozycji krajów Europy Środkowo-Wschodniej wobec Rosji i Chin, „Nowa Polityka Wschodnia” 2017, nr 12, s. 27-46.

27 K. Kik, Środkowoeuropejskie aspekty Nowego Jedwabnego Szlaku, „Kwartalnik Naukowy Uczelni Vistula” 2018, nr 4, s. 25-38. 
Tytułem dopełnienia należy podkreślić, że koncepcja Nowego Jedwabnego Szlaku stanowi narzędzie realizacji chińskich interesów w dynamicznie zmieniającym się świecie, umacniania międzynarodowej roli Chin i budowania pozycji państwa posiadającegp zdolności, możliwości i zasoby do kształtowania ładu międzynarodowego ${ }^{28}$.

W tym miejscu należy zauważyć, że wraz z upadkiem zimnowojennego podziału świata aktywność Chin wobec państw tego regionu (jak i całej Europy Środkowo-Wschodniej) znacząco osłabła. W przypadku Bałkanów Zachodnich przede wszystkim czynnikiem determinującym poziom i stopień aktywności Chin był proces rozpadu b. Jugosławii i towarzyszące mu wydarzenia, które wpływały nie tylko na rozwój i funkcjonowanie państw pojugosłowiańskich, jak również najbliższego otoczenia (mowa o Albanii). Polityka Chin wobec państw Bałkanów Zachodnich po wojnie na obszarze b. Jugosławii cechowała się dążeniem do utrzymania i wzmacniania przyjaznych relacji. Chiny utrzymywały przyjazne stosunki z krajami, takimi jak Serbia, natomiast - co należy podkreślić - przerywały stosunki dyplomatyczne z Macedonią Północną (wcześniej FYROM) ze względu na kwestię Tajwanu, jednakowoż później przywróciły te stosunki ${ }^{29}$.

Kontynuując rozważania należy stwierdzić, że przez lata państwa zachodniobałkańskie postrzegane były w Chinach jako mało znaczące, co warunkowało lokowanie kwestii współpracy z nimi na obrzeżach chińskiego zainteresowania. Dopiero ewolucja założeń polityki zagranicznej oraz redefinicja chińskiego interesu narodowego ${ }^{30}$, a także, albo przede wszystkim, akcesja

28 R. Wowra, Uwarunkowania mocarstwowości Chin, „Nowa Polityka Wschodnia" 2018, nr 3, s. 89.

29 L. Zuokui, Chinas's Investment in the Balkans under the Belt and Road Initiative: A Chines Perspective, „Insight Turkey” 2019, vol. 21, nr 2, S. 92.

30 Zob. szerzej: D. Mierzejewski, Definiowanie interesu narodowego w Chińskiej Republice Ludowej (po 1989 r.), [w:] Międzynarodowe studia po- 
części państw Europy Środkowo-Wschodniej do UE spowodowały większe, niż dotychczas zainteresowanie Chin rozwojem kontaktów z państwami Bałkanów Zachodnich ${ }^{31}$. Tym bardziej, iż te wyrażały dążenie do intensyfikacji powiązań z UE, a część $\mathrm{z}$ nich już posiadała status oficjalnego kandydata (część zaś potencjalnych kandydatów). Przede wszystkim jednak czynnikiem determinującym chińskie zainteresowanie regionem jest jego położenie geograficzne. Państwa Bałkanów Zachodnich zlokalizowane strategicznie z punktu widzenia realizacji kluczowych chińskich projektów są nieodzowne do ich pozytywnego sfinalizowania i pomimo geograficznego oddalenia stanowią element chińskiej strategii działania ${ }^{32}$. Równocześnie należy zauważyć, iż ów czynnik geograficzny powoduje, iż w odróżnieniu od innych podmiotów (Rosja, Chiny, Turcja, UE) polityczne oddziaływanie jest ograniczone ${ }^{33}$. Jednakowoż ten sam czynnik powoduje, iż Chiny wykorzystują instrumenty gospodarcze, by wzmocnić swoją pozycję w państwach Bałkanów Zachodnich w stopniu umożliwiającym im dalszą ekspansję.

Na potrzeby artykułu przyjęto założenie wskazujące na reaktywację zainteresowania Chin państwami Bałkanów Zachodnich motywowane pragmatycznymi pobudkami wynikającymi z dążenia do zwiększenia politycznego i gospodarczego oddziaływania na Europę, zmiany wizerunku Chin, promowania Chin jako państwa kreatywnego, posiadającego wizję kształtowania relacji międzynarodowych i zdolnego tę wizję urzeczywistniać.

lityczne i kulturowe wobec wyzwań wspótczesności, red. T. Domański, Łódź 2016, s. 245-259.

31 Zob. R. Podgórzańska, Wspótpraca państw Grupy wyszehradzkiej..., op.cit., s. 206-211.

32 M. Makocki, Płaca, więc wymagaja. Chińskie inwestycje na Batkanach, https://klubjagiellonski.pl/2019/07/11/placa-wiec-wymagaja-chinskie-inwestycje-na-balkanach/ [dostęp: 27.11.2019].

33 J. Lachert, Bałkany Zachodnie w kontekście rywalizacji Chin, Rosji, Unii Europejskiej i Turcji, https://cutt.ly/1eBvjJQ [dostęp: 27.11.2019]. 
Pragmatyzm, o którym mowa powyżej sprowadza się do tezy, że inwestując w państwach kluczowych z ich perspektywy (i co ważne w kluczowe branże, takie jak: infrastruktura, energetyka i nowoczesne technologie) zdobywają możliwość wejścia na rynki UE, a państwa te mogłyby zarazem spełniać rolę lobbysty chińskich interesów w $\mathrm{UE}^{34}$.

O dowartościowaniu Bałkanów Zachodnich decyduje ich geograficzne położenie i znaczenie z perspektywy sukcesów w realizacji chińskich projektów gospodarczych, a przede wszystkim wspomnianego Nowego Jedwabnego Szlaku. Państwa Bałkanów Zachodnich pełniąc role państw tranzytowych w optyce chińskiej mogą odegrać ważną rolę. Dla współczesnych Chin wspomniana powyżej koncepcja Nowego Szlaku Jedwabnego w założeniu ma umożliwić ekspansję Chin i umocnić ich pozycję w układzie międzynarodowym. Koncepcja ta jako narzędzie chińskiej polityki zagranicznej w wymiarze regionalnym i globalnym służyć ma przede wszystkim umocnieniu pozycji Chin w stosunkach międzynarodowych. Zarazem podkreślić należy, że inicjatywa mająca na celu ułatwić połączenia transportowe i handlowe i tym samym zintensyfikować współpracę gospodarczą Chin wymaga uwzględnienia wszystkich podmiotów, w tym państw Bałkanów Zachodnich pełniących rolę tranzytową w projekcie. W tym miejscu warto nadmienić, iż Chiny zaproponowały państwom Europy Środkowo-Wschodniej (w tym państwom Bałkanów Zachodnich ${ }^{35}$ ) inicjatywę „16 + 1”, które zostało wkomponowane w ideę Nowego Jedwabnego Szlaku i wzmacniać miało jego realizację na poziomie politycznym.

34 Chińskie oddziatywanie w Europie Środkowo-Wschodniej i na Bałkanach, https://warsawinstitute.org/wp-content/uploads/2019/04/Chi\%C5\%84skie-oddzia\%C5\%82ywanie-w-Europie-\%C5\%9Arodkowo-Wschodniej-i-na-Ba\%C5\%82kanach-Raport-Specjalny-Warsaw-Institute.pdf [dostęp: 27.11.2019].

35 W ramach „16 + 1" Chiny cyklicznie spotykają się ze wszystkimi, za wyjątkiem Kosowa, państwami Bałkanów Zachodnich oraz z jedenastoma państwami członkowskimi UE z Europy Środkowej i Wschodniej. 


\section{Sposoby oddziaływania Chin wobec państw Bałkanów Zachodnich - wybrane aspekty}

Punktem wyjścia do dalszych analiz jest założenie, że wraz z modyfikacją założeń chińskiej polityki zagranicznej dokonuje się modyfikacja sposobów realizacji jej wytycznych. Znajduje to swoje odzwierciedlenie w sposobach i narzędziach, jakie Chiny stosują wobec państw i regionów postrzeganych jako istotne z punktu widzenia realizacji ich interesów ${ }^{36}$. W przypadku państw Europy Środkowo-Wschodniej, w tym państw Bałkanów Zachodnich, kluczową rolę odgrywa przywołana inicjatywa "16+1", stanowiąca wyraz politycznego wsparcia dla osiągania zdefiniowanych i newralgicznych dla Chin celów w gospodarce. Ogłoszona w 2011 r. w Budapeszcie, a ustanowiona rok później (w 2012 r.) na spotkaniu w Warszawie obejmuje państwa zróżnicowane pod względem wielkości populacji, poziomu rozwoju gospodarczego, odmienności sytuacji społeczno-politycznej. Dostrzegane pomimo odnotowywanych różnic w potencjale i zasobach walory państw Europy Środkowej i Wschodniej, w tym państw Bałkanów Zachodnich, stanowią uzasadnienie zwiększonej obecności i większego zainteresowania Chin angażowaniem się w sektory kluczowe, takie jak infrastruktura transportowa, energetyka, nowoczesne technologie ${ }^{37}$. Pomijając analizę efektywności tego formatu i czynników nań wpływających stworzenie ram współpracy politycznej i gospodarczej jest

36 R. Kwieciński, Dyplomacja i nie-dyplomacja: instrumenty polityki zagranicznej ChRL na poczatku XXI wieku, https://bit.ly/2z54D4q [dostęp: 10.10.2018].

37 Zob. M. Kaczmarski, J. Jakóbowski, Chiny - Europa Środkowo-Wschodnia: „16+1" widziane $z$ Pekinu, https://www.osw.waw.pl/sites/default/files/komentarze_166.pdf [dostęp: 27.11.2019]; D. Mierzejewski, B. Kowalski, P. Ciborek, Aktywność gospodarcza i polityczna Chińskiej Republiki Ludowej w Europie Środkowej $i$ Wschodniej, Raport Ośrodka Spraw Azjatyckich, Łódź 2018, s. 9. 
(bądź bliższe prawdy może być) istotnym czynnikiem intensyfikującym relacje regionu z Państwem Środka.

Przywołując pogląd Marty Szpali zauważyć należy, iż dla państw regionu należących do UE współpraca z Chinami jest kwestią wyboru, a nie konieczności. Natomiast w przypadku państw Bałkanów Zachodnich chińskie wsparcie umożliwi realizację nieodzownych dla gospodarki przedsięwzięć w transporcie drogowym, sieci kolejowej i energetyce ${ }^{38}$. Co więcej, niezadowalające tempo włączania się państw w regionu w struktury UE (niezależnie od przyczyn spowolnienia procesu akcesji) motywuje je do poszukiwania instrumentów nacisku na UE w tym względzie $^{39}$. Z całą pewnością alternatywa w postaci współpracy z Chinami i możliwości korzystania z ich ekonomicznego wsparcia jest w tym przypadku przesłanką towarzyszącą decyzjom politycznym zachodniobałkańskich rządów. W tym miejscu warto zasygnalizować, że chińska obecność w regionie z jednej strony widziana jest jako czynnik mogący w perspektywie wspomóc rozwój regionu, z drugiej zaś postrzegana jest negatywnie jako czynnik obciążający relacje UE-Bałkany Zachodnie. Dostrzega się powody zainteresowania państw regionu współpracą z Chinami i dążenia do inicjowania nowych powiązań gospodarczych z Chinami, w których upatruje się atrakcyjny podmiot współpracy gospodarczej i handlowej. Jednakowoż kwestia realizacji wielu przedsięwzięć budzi wiele kontrowersji w zakresie jasności i przejrzystości prawa czy formułowanych zarzutów o korupcję na wysokim szczeblu, ale przede wszystkim zwraca się uwagę na fakt, że chińska obecność w regionie podważa polityczną determinację poszczególnych państw regionu na rzecz

38 M. Szpala, Chiny „wyręczają” Unię Europejską na Batkanach Zachodnich, https://www.wnp.pl/rynki-zagraniczne/chiny-wyreczaja-unie-europejska-na-balkanach-zachodnich,311981.html [dostęp: 27.11.2019].

39 Działania Chin na Batkanach, http://osa.uni.lodz.pl/?p=8440 [dostęp: 27.11.2019]. 
ich integracji z UE ${ }^{40}$. Akcentuje się również możliwy negatywny wpływ obecności Chin na Bałkanach Zachodnich w kontekście zarządzania społecznego i gospodarczego, a przede wszystkim problemu praworządności i praw człowieka ${ }^{41}$. Zarazem należy zauważyć, że zaangażowanie Chin w regionie (podobnie, jak i innych, niż UE podmiotów) jest argumentem na rzecz zaktywizowania polityki rozszerzenia po to, „by zwiększyć odporność partnerów UE i zapewnić pełne poszanowanie przez nich wartości, norm i standardów UE"42.

Nie jest celem rozważań głębsza analiza skali i charakteru mechanizmów współpracy gospodarczej Chin z regionem Europy Środkowo-Wschodniej. W tym miejscu należy jednakże podkreślić, iż zakładane rezultaty inicjatywy $16+1$ jako głównego narzędzia służącego poszerzaniu sfery oddziaływania Chin na Europę Środkową i Wschodnią są odnotowywane głównie w przypadku pięciu państw Bałkanów Zachodnich. Jak zauważają Marcin Kaczmarski i Jakub Jakubowski, po kilku latach funkcjonowania formatu współpraca w jego ramach wyraźnie podzieliła się wzdłuż linii członkostwa w UE. W pięciu państwach „16” nienależących do UE (Serbia, Czarnogóra, Albania, Macedonia, Bośnia i Hercegowina) prowadzone są działania, zaś w pozostałych państwach należących do Unii Europejskiej, pomimo intensywnych kontaktów politycznych z Chinami, dynamika współpracy infrastrukturalnej wciąż pozostaje daleka od oczekiwań (za wyjątkiem Węgier) ${ }^{43}$. Z uwagi na dotychczas

40 Interpelacja z 12 lipca 2018 roku, http://www.europarl.europa.eu/ doceo/document/E-8-2018-003860_PL.html?redirect [dostęp: 27.11.2019].

41 Wspólny Komunikat do Parlamentu Europejskiego, Rady Europejskiej i Rady UE-Chiny - perspektywa strategiczna, Wysoki Przedstawiciel Unii do Spraw Zagranicznych i Polityki Bezpieczeństwa, Strasburg, 12.03.2019 r., s. 5-6, https://ec.europa.eu/commission/sites/beta-political/files/communication-eu-china-a-strategic-outlook_pl.pdf [dostęp: 27.11.2019].

42 Ibidem.

43 Por. A. Denková, E. Zgut, K. Zbytniewska, L. Hendrych, M. Koreň, 
formułowane wymogi oferta chińska - na co wskazują dane statystyczne - znajduje zainteresowanie właśnie w państwach Bałkanów Zachodnich, które poszukując możliwości sfinansowania swoich projektów infrastrukturalnych (a nie mogąc w krótkim sprostać wymogom UE w tym zakresie) w oferowanym przez Chiny narzędziu widzą szansę. W przypadku państw Unii Europejskiej brak consensusu politycznego w UE wobec Chin i jej polityki, a przede wszystkim niezadowalające prawne uregulowania współpracy negatywnie warunkowały możliwość skorzystania z chińskiej oferty z korzyścią zarówno dla państw wchodzących w skład formatu, jak i całej Unii Europejskiej.

Dostrzec należy, iż zwiększeniu atrakcyjności tego formatu służą ustalenia ostatniego szczytu premierów państw Europy Środkowo-Wschodniej i Chin, który odbył się w Dubrowniku 11-12 kwietnia 2019 r. Najważniejsze zmiany związane z tą formułą to te czyniące ją narzędziem dopełniającym dialog UE-Chiny oraz przyjęcie Grecji jako kolejnego państwa zainteresowanego intensyfikacją współpracy z Chinami $(17+1)^{44}$. Równocześnie ustalenia szczytu wskazują na przekierowanie dotychczasowej aktywności Chin z państw Bałkanów Zachodnich (w których realizowane są określone projekty) na państwa członkowskie, które dotychczas niemal zupełnie nie były zaangażowane i nie korzystały ze wsparcia. Wystarczy wspomnieć, iż do tej pory to do nich skierowana była większość chińskich za-

Chiny $i$ Grupa Wyszehradzka: Wspótpraca $w$ ramach 16+1, czyli wiele hałasu o nic, https://www.euractiv.pl/section/grupa-wyszehradzka/special_report/ chiny-i-grupa-wyszehradzka-161-wiele-halasu-o-nic/ [dostęp: 27.11.2019]; M. Kaczmarski, J. Jakubowski, Nietrafiona oferta Pekinu: „16+1” a chińska polityka wobec Unii Europejskiej, https://www.osw.waw.pl/pl/publikacje/ komentarze-osw/2017-09-15/nietrafiona-oferta-pekinu-161-a-chinska-polityka-wobec-unii [dostęp: 27.11.2019].

44 J. Jakubowski, M. Seroka, Szczyt w Dubrowniku: europeizacja i rozszerzenie formatu 16+1, https://www.osw.waw.pl/pl/publikacje/analizy/2019-04-17/szczyt-w-dubrowniku-europeizacja-i-rozszerzenie-formatu-161 [dostęp: 29.11.2019]. 
sobów ${ }^{45}$. Przy czym podkreślić należy, że o istniejącej nierównowadze dotyczącej poziomu współpracy poszczególnych państw regionu z Chinami ${ }^{46}$. Chiny są wprawdzie obecne w mniejszym czy większym stopniu we wszystkich państwach Bałkanów Zachodnich jednakże udział ów jest zróżnicowany również z uwagi na rolę jaką państwa zachodnio-bałkańskie przypisują Chinom w kontekście własnej strategii rozwoju. W tym przypadku mowa o Serbii, która Chiny postrzega jako istotne państwo z punktu widzenia realizacji założeń polityki zagranicznej ${ }^{47}$ i państwo umożliwiające jej zarazem realizację licznych projektów infrastrukturalnych sprzyjających rozwojowi społeczno-gospodarczemu i pokonaniu historycznej spuścizny ${ }^{48}$. Natomiast dla Chin Serbia odgrywa istotne znaczenie w związku z budową korytarza transportowego między portem w Pireusie a Europa Środkową zapewniającego im w przyszłości uruchomienie nowych możliwości handlowych ${ }^{49}$. Nadmienić należy, że wzorem

45 Ibidem.

46 Dla przykładu w Serbii oraz Bośni i Hercegowinie dzięki instrumentom finansowym oferowanym przez Chiny powstają elektrociepłownie węglowe, w Albanii, Czarnogórze, Macedonii Północnej autostrady. Również istotne jest wsparcie dla projektów infrastruktury kolejowej w państwach regionu. Zob. Chińskie oddziatywanie w Europie Srodkowo-Wschodniej i na Bałkanach..., op.cit.

47 Zob. Bilateral issues with foreign countries, http://www.mfa.gov.rs/ en/foreign-policy/bilateral-issues/96-bilateral-issues/12256-kina [dostęp: 29.11.2019]; S. Jojić, How Serbia perceives "The Belt and the Road" Initiative and 16+1 Cooperation, „Working Paper” 2017, nr 9.

48 Na znaczącą pozycję Serbii wskazuje również analiza komunikatów dokonana przez D. Mierzejewskiego, B. Kowalskiego, P. Ciborka. Serbia zakwalifikowana jest do liderów formatu, będąc kilkadziesiąt razy wzmiankowaną w corocznych komunikatach. Pozostałe państwa regionu zainteresowane są jedynie określonymi sektorami współpracy, w odróżnieniu od wspomnianej Serbii. Zob D. Mierzejewski, B. Kowalski, P. Ciborek, Aktywność gospodarcza i polityczna Chińskiej Republiki Ludowej w Europie Środkowej $i$ Wschodniej, Raport Ośrodka Spraw Azjatyckich, Łódź 2018, s. 9-10.

49 J. Jakubowski, Xi Jinping w Serbii: nie tylko gospodarka, https://www. osw.waw.pl/pl/publikacje/analizy/2016-06-22/xi-jinping-w-serbii-nie-tylkogospodarka [dostęp: 29.11.2019]. 
większości państw Chiny są znaczącym partnerem handlowym, przede wszystkim jednak dostarczając towary na rynki bałkańskie. Wielkość eksportu towarów z państw Bałkanów Zachodnich do Chin jest niewielka i koncentruje się przede wszystkim na bałkańskim i unijnym obszarze ${ }^{50}$.

Nie należy przeceniać wielkości chińskiego zaangażowania na Bałkanach, gdyż możliwości jakie oferują Chiny mają charakter subsydiarny wsparcia oferowanego przez UE. W pewnym sensie może ono spełniać funkcję dynamizującą politykę UE wobec Bałkanów Zachodnich, która obawiając się zmarginalizowania swej roli i co najważniejsze zahamowania europejskich aspiracji państw regionu, zintensyfikuje podejmowane działania.

\section{Zakończenie}

Systematyzując dotychczasowe uwagi należy podkreślić, iż o charakterze współpracy Chin z państwami Bałkanów Zachodnich decydują dwojakiego rodzaju uwarunkowania. Po pierwsze, istotną rolę odgrywają te, które można określić mianem „wewnątrzchińskich”. Na tę grupę składają się m.in. czynniki ulokowane w sytuacji wewnętrznej Chin, strategia polityki zagranicznej, wizja rozwoju stosunków międzynarodowych, zdefiniowane interesy i oczekiwania w środowisku międzynarodowym. Druga grupa uwarunkowań obejmuje czynniki ulokowane w naturze państw bałkańskich, założenia polityki zagranicznej państw zachodniobałkańskich, posiadane instrumenty oddziaływania na środowisko międzynarodowe, rolę i pozycję w stosunkach międzynarodowych, percepcję chińskiej rzeczywistości politycznej i gospodarczej.

50 Potwierdzają to statystyki obrazujące wielkość wymiany towarowej. Zob. https://www.cia.gov/library/publications/the-world-factbook/geos/ al.html [dostęp: 29.11.2019]. 
Politykę Chin wobec subregionu Bałkanów Zachodnich cechuje pragmatyzm, wyrażający się w działaniach zmierzających do uzyskania wpływu w regionie, a za jego pośrednictwem umożliwienie poszerzenia sfery oddziaływania na Europę. Podkreślić bowiem należy, że proponowane przez Chiny inicjatywy mają na celu umocnienie pozycji tego państwa w Europie i potwierdzić ich zdolności do kształtowania układu międzynarodowego. Motywowane interesem narodowym oferują państwom Bałkanów Zachodnich, postrzeganym jako element większej całości jakim jest region Europy Środkowo-Wschodniej, wsparcie dążąc przy tym do zrealizowania własnych celów politycznych i gospodarczych.

\section{Bibliografia}

Balcer A., Kierunek Bałkany! Znaczenie i potencjat wspótpracy Polski z państwami Batkanów Zachodnich, https://cutt.ly/ peBc9uR.

Biberaj E., Albania In Transition: The Rocky Road To Democracy, London 1999.

Bilateral issues with foreign countries, http://www.mfa.gov. rs/en/foreign-policy/bilateral-issues/96-bilateral-issues/ 12256-kina.

Bujwid-Kurek E., Państwa o proweniencji jugosłowiańskiej w procesie rozszerzania Unii Europejskiej - refleksje politologiczne, „Politeja” 2018, nr 5.

Bukowski P., Geopolityczne źródta potencjalnych konfliktów w zachodniej części Bałkanów, „Przegląd Geopolityczny” 2018, nr 24.

Chińskie oddziaływanie w Europie Środkowo-Wschodniej $i$ na Batkanach, https://warsawinstitute.org/wp-content/ uploads/2019/04/Chi\%C5\%84skie-oddzia\%C5\%82ywanie-w- 
-Europie-\%C5\%9Arodkowo-Wschodniej-i-na-Ba\%C5\%82kanach-Raport-Specjalny-Warsaw-Institute.pdf.

Commission Staff Working Document Albania 2019 Report Accompanying the document Communication from the Commission to the European Parliament, the Council, the European Economic and Social Committee and the Committee of the Regions 2019 Communication on EU Enlargement Policy [COM(2019) 260 final], https://ec.europa.eu/ neighbourhood-enlargement/sites/near/files/20190529-albania-report.pdf.

Denková A., Zgut E., Zbytniewska K., Hendrych L., Koreň M., Chiny i Grupa Wyszehradzka: Wspótpraca w ramach „16+1, czyli wiele hatasu o nic, https://www.euractiv.pl/section/grupa-wyszehradzka/special_report/chiny-i-grupa-wyszehradzka-161-wiele-halasu-o-nic/.

Działania Chin na Bałkanach, http://osa.uni.lodz.pl/?p=8440. Global Peace Index 2019, s. 9, http://visionofhumanity.org/ app/uploads/2019/07/GPI-2019web.pdf.

Global Terrorism Index 2019, s. 9, http://visionofhumanity. org/app/uploads/2019/11/GTI-2019web.pdf.

Góralczyk B., Geostrategia Xi Jinpinga - Chiny ruszaja w świat, „Rocznik Strategiczny” 2016/2017.

Góralczyk B., Polska na trasie chińskiego Jedwabnego Szlaku: szansa rozwojowa czy tylko wyzwanie?, http://wz.uw.edu.pl/ portaleFiles/6133-wydawnictwo-/nowa_polityka_strukturalna/Bogdan_J._Goralczyk.pdf.

Hake M., Radzyner A., Western Balkans: Growing economic ties with Turkey, Russia and China, https://helda.helsinki. fi/bof/bitstream/handle/123456789/16048/bpb0119.pdf?sequence $=1$.

Interpelacja z 12 lipca 2018 roku, http://www.europarl.europa.eu/doceo/document/E-8-2018-003860_PL.html?redirect. 
Jakimowicz R., Nowy Jedwabny Szlak a wzrost pozycji krajów Europy Srodkowo-Wschodniej wobec Rosji i Chin, „Nowa Polityka Wschodnia" 2017, nr 12.

Jakubowski J., Seroka M., Szczyt w Dubrowniku: europeizacja i rozszerzenie formatu "16+1", https://www.osw.waw.pl/pl/ publikacje/analizy/2019-04-17/szczyt-w-dubrowniku-europeizacja-i-rozszerzenie-formatu-161.

Jakubowski J., Xi Jinping w Serbii: nie tylko gospodarka, https://www.osw.waw.pl/pl/publikacje/analizy/2016-06-22/ xi-jinping-w-serbii-nie-tylko-gospodarka.

Jojić S., How Serbia perceives "The Belt and the Road" Initiative and "16+1" Cooperation, „Working Paper" 2017, nr 9.

Kaczmarski M., Chiny - Europa Środkowo-Wschodnia: „16+1" widziane z Pekinu, „Komentarze OSW”, 15.04.2015, nr 166. Kaczmarski M., Jakóbowski J., Chiny - Europa Środkowo-Wschodnia: „16+1" widziane $z$ Pekinu, https://www.osw.waw.pl/sites/ default/files/komentarze_166.pdf.

Kaczmarski M., Jakubowski J., Nietrafiona oferta Pekinu: „16+1” a chińska polityka wobec Unii Europejskiej, https://www.osw. waw.pl/pl/publikacje/komentarze-osw/2017-09-15/nietrafiona-oferta-pekinu-161-a-chinska-polityka-wobec-unii.

Kik K., Środkowoeuropejskie aspekty Nowego Jedwabnego Szla$k u$, „Kwartalnik Naukowy Uczelni Vistula” 2018, nr 4.

Koszyk R., Kraje Europy Środkowo-Wschodniej wobec ekspansji chińskiej gospodarki, „Prace Komisji Geografii Przemysłu Polskiego Towarzystwa Geograficznego" 2016, nr 1.

Kwieciński R., Dyplomacja i nie-dyplomacja: instrumenty polityki zagranicznej ChRL na poczatku XXI wieku, https:// bit.ly/2z54D4q.

Lach Z., Analiza poziomu rozwoju społecznoekonomicznego i potęgi państw Europy Środkowo-Wschodniej, „Przegląd Geopolityczny. Geopolitical Review" 2014, nr 9. 
Lachert J., Bałkany Zachodnie w kontekście rywalizacji Chin, Rosji, Unii Europejskiej i Turcji, https://cutt.ly/1eBvjJQ.

Makocki M., Ptaca, więc wymagaja. Chińskie inwestycje na Batkanach, https://klubjagiellonski.pl/2019/07/11/placa-wiec-wymagaja-chinskie-inwestycje-na-balkanach/.

Mierzejewski D., Definiowanie interesu narodowego w Chińskiej Republice Ludowej (po 1989 r.), [w:] Międzynarodowe studia polityczne i kulturowe wobec wyzwań wspótczesności, red. T. Domański, Łódź 2016.

Mierzejewski D., Kowalski B., Ciborek P., Aktywność gospodarcza i polityczna Chińskiej Republiki Ludowej w Europie Srodkowej i Wschodniej, Raport Ośrodka Spraw Azjatyckich, Łódź 2018.

Miśkiewicz R., Transparency in Knowledge Transfer Processes in an Enterprise, „Przegląd Organizacji” 2018, nr 8.

Podgórzańska R., Albania w procesie integracji z UE - stan i perspektywy akcesji, „Rocznik Integracji Europejskiej” 2018, nr 12.

Podgórzańska R., The migration crisis from the perspective of the Central and Eastern Europe. Challenges for regional security, „Yearbook” 2017.

Podgórzańska R., Wspótpraca państw Grupy Wyszehradzkiej $z$ Chińska Republika Ludowa. Możliwości i ograniczenia, [w:] Wspótpraca i rywalizacja państw azjatyckich, red. J. Marszałek-Kawa, J. Zajączkowski, Toruń 2018.

Potulski J., Chińska polityka zagraniczna, [w:] Wyzwania gospodarcze i polityczne państw Dalekiego Wschodu, red. J. Marszałek-Kawa, G. Kądzielewski, K. Zamsza, Torun 2018.

Serwer D., Can the Balkans Join the West?, https://link.springer.com/content/pdf/10.1007\%2F978-3-030-02173-3_6.

Sirecka-Wołodko M., Regionalizm w stosunkach międzynarodowych, [w:] Wspótczesne stosunki międzynarodowe, red. T. Łoś-Nowak, Wrocław 2008.

Stronski P., Himes A., Russia's Game in the Balkans, Carnegie 
Endowment for International Peace, https://euagenda.eu/ upload/publications/untitled-203333-ea.pdf.

Szpala, M., Chiny „wyręczaja” Unię Europejska na Batkanach Zachodnich, https://www.wnp.pl/rynki-zagraniczne/ chiny-wyreczaja-unie-europejska-na-balkanach-zachodnich,311981.html.

Szymczak M. (red.), Stownik jezyka polskiego, t. III, Warszawa 1989.

Walkowski M., Chiński model rozwoju społeczno-gospodarczego i jego potencjalna adaptacja $w$ Europie, „Rocznik Strategiczny" 2017, nr 10.

Western Balkans Regular Economic Report No. 16. Rising Uncertainties, http://documents.worldbank.org/curated/en/6437 81570478210132/pdf/Rising-Uncertainties.pdf.

Wowra R., Uwarunkowania mocarstwowości Chin, „Nowa Polityka Wschodnia" 2018, nr 3.

Wspólny Komunikat do Parlamentu Europejskiego, Rady Europejskiej i Rady UE-Chiny - perspektywa strategiczna, Wysoki Przedstawiciel Unii do Spraw Zagranicznych i Polityki Bezpieczeństwa, Strasburg, dnia 12.03.2019 r., https:// ec.europa.eu/commission/sites/beta-political/files/communication-eu-china-a-strategic-outlook_pl.pdf.

Znamierowska-Rakk E., Pojęcie i tożsamość Europy Środkowo-Wschodniej w historiografii makroregionu i opinii elit Zacho$d u$, „Studia z Dziejów Rosji i Europy Środkowo-Wschodniej” 2010, nr XLV.

Zuokui L., Chinas's Investment in the Balkans under the Belt and Road Initiative: A Chines Perspective, „Insight Turkey” 2019, vol. 21, nr 2.

Żukrowska K., Chiny: potencjał (gospodarczy, polityczny i militarny) jako instrument kształtowania nowego układu międzynarodowego, „Krakowskie Studia Małopolskie” 2018, nr 1. 


\section{Abstrakt}

Celem artykułu jest analiza czynników determinujących politykę CHRL wobec Bałkanów Zachodnich oraz charakterystyka sposobów oddziaływania na bałkańską rzeczywistość. Pomimo różnicy potencjałów Chiny postrzegają tę część kontynentu jako ważną z punktu widzenia realizacji chińskiej strategii umacniania wpływów w Europie Środkowo-Wschodniej. Podkreślić należy, iż proponowane przez Chiny inicjatywy mają na celu umocnienie pozycji tego państwa w Europie i potwierdzić ich zdolności do kształtowania układu międzynarodowego. Motywowane interesem narodowym oferują państwom Bałkanów Zachodnich oraz pozostałym państwom Europy Środkowo-Wschodniej wsparcie, oczekując przy tym zrealizowania własnych celów politycznych i gospodarczych. Przykładem jest inicjatywa „16+1”, będąca wyrazem politycznego wsparcia w osiąganiu kluczowych celów gospodarczych Chin. Równie istotną przesłanką zaangażowania jest chęć zmiany wizerunku Chin na arenie międzynarodowej, promowanie ich jako państwa kreatywnego, posiadającego wizję kształtowania relacji międzynarodowych i zdolnego tę wizję urzeczywistniać.

Główne metody badawcze wykorzystane w tekście to krytyczna analiza dokumentów i literatury przedmiotu oraz metoda komparatystyczna.

Słowa kluczowe: Bałkany Zachodnie, stosunki międzynarodowe, polityka zagraniczna, współpraca gospodarcza

\section{Abstract}

The aim of the paper is to analyse factors that determine the PRC's policy towards the Western Balkans and to characterize the manner of impact on the Balkan reality. Despite the difference in potentials, China is perceiving this part of the continent as important from the point of view of implementation of the Chinese strategy for strengthening its influence in Central and Eastern Europe. It needs to be emphasized that the initiatives proposed by China aim to strengthen its position in Europe and to confirm its capacity to shape the international order. Motivated by the national interest, it offers the Western Balkan countries and other countries of the Central and Eastern Europe support expecting that its own political and economic goals are achieved. The example here is the "16+1" initiative which provides political support for achieving China's key economic objectives. The desire to change China's image on the 
international arena, promoting it as a creative country that has a vision for shaping international relations and is capable of making this vision reality is an equally important premise for its involvement.

Main research methods applied in the text involve a critical analysis of documents and literature as well as the comparative method.

Keywords: Western Balkans, international relations, foreign policy, economic cooperation 


\section{Wioleta Gierszewska}

Uniwersytet Gdański

ORCID ID: https://orcid.org/0000-0002-5024-9379

\section{Obecność Chin w Rwandzie w sferze polityczno-gospodarczej}

W latach 90. XX w. Chiny zaczęły systematycznie zwiększać swoją obecność w Afryce Subsaharyjskiej. Zaangażowanie Państwa Środka napędzała potrzeba pozyskiwania zasobów naturalnych oraz dostępu do tamtejszych rynków konsumenckich ${ }^{1}$. Mimo że Rwanda nie posiada dużej ilości zasobów surowców to graniczy z państwami bogatymi w złoża naturalne, co więcej zajmuje strategiczne miejsce $w$ regionie, gdyż jest państwem względnie stabilnym i rozwijającym się. W przeciwieństwie do niektórych państw ościennych, zwłaszcza uznanych za upadłe, jak Demokratyczna Republika Konga czy Burundi, prowadzenie wszelkich inwestycji biznesowych w Rwandzie jest względnie bezpieczne. Stosunki dyplomatyczne między Chińską Republiką Ludową a Rwandą nawiązano 12 listopada $1971 \mathrm{r}$. Zaowocowały one wspólnymi inicjatywami, między innymi w sferze edukacji, zdrowia, kultury, a przede wszystkim w różnych sektorach gospodarki. Między innymi w 1983 r. Chiny wybudowały szpital w dawnej prowincji Kibungo (obecnie Prowincja Wschodnia).

Państwo Środka wspierało rząd Rwandy nie ingerując w wewnętrzne sprawy tego kraju, jak między innymi kwestie łamania praw człowieka, również w toku waśni etnicznych. To między innymi Francuzi i Chińczycy sprzedawali do Rwandy maczety

$1 \quad$ Ł. Firmanty, Afryka we wspótczesnej polityce Chińskiej Republiki Ludowej, Toruń 2013, s. 146-147. 
podczas konfliktu etnicznego między Tutsi a Hutu. Należy zaznaczyć, że przez niemalże cały ubiegły wiek Rwanda była państwem źle zarządzanym, a destabilizację wewnętrzną wspierały państwa Zachodu i część azjatyckich. Rwandyjskie reżimy kolonialne, a następnie postkolonialne, sprawowały rządy między innymi za pomocą wzniecania konfliktów społecznych, zwłaszcza międzyetnicznych. Skutecznie niszczono przedkolonialne wartości lokalnych społeczności, wdrażając europejskie, nasycone rasizmem, wzorce zarządzania. W konsekwencji Rwanda stała się jednym z najuboższych i najbardziej podzielonych wewnętrznie państw świata ${ }^{2}$.

1994 r. stanowił pewien przełom w relacjach międzynarodowych Rwandy. Rwandyjski Front Patriotyczny przejął kontrolę nad państwem, co skutkowało zmianą rządów i wprowadzeniem szeregu zmian w sferze polityczno-gospodarczej ${ }^{3}$. Dwie najważniejsze to: podjęcie usilnych starań w celu doprowadzenia do jedności w społeczeństwie Rwandy, głównie poprzez odwoływanie się do przedkolonialnych wartości społecznych oraz rozwój ekonomiczny kraju. Mimo wydarzeń w 1994 r. Chiny nie zamierzały rezygnować z wpływów w regionie, zaś Rwanda potrzebowała pomocy w odbudowie kraju $\mathrm{u}^{4}$. Przystępując do realizacji swoich planów, Chińczycy przede wszystkim podjęli inicjatywy mające na celu uhonorowanie zamordowanych w konflikcie etnicznym, a następnie zaproponowali szereg wspólnych inicjatyw gospodarczych na rzecz odbudowy zrujnowanego kraju. Co więcej, były pierwszym państwem, który po zakończeniu konfliktu ponownie otworzył swoją ambasadę

2 J.P. Chretien, The Great Lakes of Africa. Two thousand Years of History, tłum. S. Straus, New York 2006, s. 317-346.; J. Bar, Po ludobójstwie: państwo i spoleczeństwo w Rwandzie 1994-2012, Kraków 2013, s. 48-50.

3 J. Bar, Rwanda, Warszawa 2013, s. 68-87.

4 Minaffet Ministry of Foreign Affairs and Cooperation, The Diplomatic Magazine, Ministry of Foreign Affairs and International Cooperation, Kigali, Rwanda 2009. 
w Kigali. Zespoły medyczne z Chin leczyły chorych i szkoliły lekarzy. Rząd chiński zaoferował Rwandyjczykom szereg stypendiów dla studentów w różnych dziedzinach nauki. Zobowiązał się do wyasygnowania środków na poprawę stanu rolnictwa w Rwandzie. Dzięki pomocy technicznej wprowadzono i rozwinięto uprawę ryżu w regionach Rwamagana i Umutara.

Chiński system oparty na kapitalizmie państwowym pozwala na realizację dużych projektów infrastrukturalnych po niższych od konkurencji międzynarodowej kosztach. Odkąd Chiny zaczęły inwestować w Rwandzie, kraj ten odnosi znacznie większe sukcesy w rozwoju gospodarczym ${ }^{5}$. Paul Kagame w przemówieniach niejednokrotnie podkreślał: „Współpraca z Chinami to dobre partnerstwo, które utrzymuje zapotrzebowanie na biznes i inwestycje w regionie"6. Potwierdza to również Vivian Kayitesi - dyrektor ds. promocji inwestycji w Rwanda Development Board. Według Kayitesi głównym obszarem chińskich inwestycji w Rwandzie są budownictwo, nieruchomości, hotele i branża telekomunikacyjna. Od 1994 do 2014 r. wartość chińskich inwestycji wyniosła prawie 200 mln dolarów.

W ciągu ostatnich kilku lat wymiana handlowa Rwandy z Chinami rosła szybciej niż z jakimkolwiek innym państwem. Import Rwandy z Chin obejmował przede wszystkim elektronikę, materiały budowlane, obuwie, ubrania i maszyny produkcyjne, między innymi do wytwarzania towarów, takich jak cegły czy torebki, herbaty. Chiny głównie importują skóry surowe i minerały z Rwandy. Dla przykładu Rwanda eksportuje 10\%

5 J. Gu, A. Carty, China and African Development: Partnership not Mentoring, „IDS Bulletin” 2014, vol. 45, nr 4, s. 57-69; Nanda Kamakshi, New 'Friends' of Rwanda - Chinese Noodles and Indian Curry: An Analysis of Asian Giants' Forays into Rwanda in the Light of Theories on OFDI, [w:] Rwanda Fast Forward, red. M. Campioni et al., London 2012, s. 145-146.

6 P. Kagame, Remarks by president Kagame at $5^{\text {th }}$ investing in Africa Forum, Brazzaville, 10.09.2019, http://paulkagame.com/?p=14722 [dostęp: 15.01.2020]. 
rudy cyny (wycenionej na 3,8 mld dolarów), 42\% nobium i tantalu (wycenionych na 8,2 mld dolarów) i 57\% rudy wolframu (10,2 mld dolarów) sprowadzanych do Chin ${ }^{7}$. Chińscy inżynierowie zaprojektowali i zbudowali najwyższy budynek w kraju, Kigali City Tower (20-piętrowy szklany wieżowiec) oraz - jak podkreślał ambasador Chin w Rwandzie - 80\% dróg. Chińskie Ministerstwo Edukacji otwiera Instytut Konfucjusza, w którym Rwandyjczycy uczyć się będą języka chińskiego. Każdego roku setki rwandyjskich studentów otrzymuje stypendia na studia w Państwie Środka ${ }^{8}$. Kompleks budynków rządowych w Kigali, o wartości 27 mln dolarów, stanowi prezent od władz chińskich dla Rwandy. Rwandyjski premier Édouard Ngirente, doceniając wartość daru, stwierdził, że jest on: „kolejnym wskaźnikiem tego, jak relacje między Chinami i Rwandą się wzmacniają". Nie tylko siedziba rządu, ale również szereg kompleksów przemysłowych, znaczna ilość mieszkań dla wschodzącej klasy średniej zostały w większości zbudowane przez Chińczyków. Projekty te oznaczono czerwonymi flagami, gwiazdami i tablicami, które świadczą i przypominają o rosnącym udziale chińskich inwestycji w Rwandzie i całym regionie ${ }^{9}$. Dowodzi tego również utworzenie

7 D. Nzohabonimana, Boom Town: Kigali's Chinese investment, https://www.pambazuka.org/governance/boom-town-kigali's-chinese-investment?\&_cf_chl_captcha_tk_=2cdc11ebfa494da09900811ed2c50a010ec14ade-1582380961-0-ARPy8YNm8YQi9bQHEMIxyu1PFzMpGgqmudbR-2bwg7qUdPK7zYs0-lO0gXR80X1LUAkdZlFvsP8g6HwwEqc_66e8kOQqoyAfRuWNdnCdp0oh_HUkIRbUDzlBweSPT4cMywq5MuhnKGcmOs3EJHTqLHYHQDWBYV̄hOH-jxLW6dMwIBGi-X00k6B1nUmOvGYgPTPGD5JB1FpeENxnbIP4DO-3n2qFLqarhQIFM4Cdtpq2gvxTwj8i0Y2s0WSw7H9qeLI_p1u7U18JA9doO1nsswia4QrUw-OiSqowq9jdvIF_Mpmxod7vFMqBNPWR_lpYQIW7sG4gcGv2zKYDFRDdZkgJ1THUgRYqckrmeDH9vHuDDzoyEaHy-cKH7bPN7e_bTlAOzBOPR40rVDBmx_zAJUSmYhvP7KLr75bUNDStVdUkKJg51KazGXAKEblYMe9H4FtQ [dostęp: 14.07.2019].

8 W całym regionie Afryki Subsaharyjskiej zwiększa się ilość Instytutów Konfucjusza i wspólnych projektów w zakresie edukacji. Szerzej: Ł. Firmanty, op.cit, s. 188-189.

9 S. Paduano, China's Investments in Rwanda Raise Familiar Questions 
sfery ekonomicznej na obrzeżach Kigali „Prime Economy Zone”. Centrum przemysłowe zostało zbudowane w większości przez chińskie firmy, m.in. przez China Star Construction Co. Ltd. Jest ono motorem wzrostu gospodarczego w ostatnich latach. Dziesiątki milionów dolarów wpływają również do słabo rozwiniętej prowincji wschodniej w Rwandzie, gdzie Chiny finansują i budują trzy wielotysięczne stadiony.

Obecność Chin jest również widoczna w innych obszarach życia państwa. Wzorem Chin Rwanda przyjęła system centralnego planowania gospodarczego. Jednostki rwandyjskiej armii posługują się językiem chińskim i są szkolone przez Chińczyków ${ }^{10}$. Z kolei rząd Rwandy odrzucił zasady liberalnej demokracji, znosząc ograniczenia w sprawowaniu władzy dla swojego długoletniego przywódcy prezydenta Paula Kagame. Ten ostatni na szczycie Forum Współpracy Chiny-Afryka we wrześniu 2018 r. podkreślał: „Stosunki między Afryką a Chinami są oparte na równości, wzajemnym szacunku i zaangażowaniu na rzecz wspólnego dobrobytu. Wszyscy, którzy planują interesy na kontynencie czerpią z niego korzyści, a Chiny udowodniły swoim wsparciem i inwestycjami, że są szczerym przyjacielem" ${ }^{11}$. Kagame niejednokrotnie podkreślał, iż współpracę ułatwia podobieństwo historycznych cierpień i doświadczeń. Co ważne, Afrykanie uważają się za ludzi stojących na drodze do dobrobytu i tak są traktowani przez Chińczyków ${ }^{12}$.

Dla Rwandy Chiny są atrakcyjnym partnerem inwestycyjnym i w sferze udzielania pomocy w różnych sektorach życia pań-

About Debt, https://www.msn.com/en-gb/news/other/chinas-investments-inrwanda-raise-familiar-questions-about-debt/ar-AAFhUSA [dostęp: 16.11.2019].

10 Ibidem.

11 P. Kagame, President Kagame attends Opening of China-Africa Cooperation Summit, http://paulkagame.com/?p=13338 [dostęp: 15.01.2020].

12 Idem, Remarks by president Paul Kagame at the State banquet in Honors of President XI Jinping of the People's Republic of China, http://paulkagame.com/?p=13133 [dostęp: 15.01.2020]. 
stwa. Prywatne chińskie konsorcja i przedsiębiorcy inwestują w nieruchomości, telekomunikację, produkcję i rozwój małych lokalnych firm, takich jak: restauracje, salony importowanych samochodów czy biura podróży. Duże chińskie przedsiębiorstwa państwowe budują większość dróg i prowadzą inwestycje w sferze infrastruktury w Rwandzie. Przy czym chińskie zaangażowanie nie jest determinowane uzyskiwaniem w zamian prawa do eksploatacji niewielkich złóż miejscowej ropy i surowców naturalnych, jak ma to miejsce w innych państwach Afryki ${ }^{13}$. Z bogactw naturalnych Chiny importują stosunkowo niewielką ilość minerałów z Rwandy, która jest wiodącym eksporterem tantalu, metalu używanego w telefonach komórkowych.

Zaangażowanie Chin w regionie Afryki Subsaharyjskiej jest tematem wielu debat naukowców i specjalistów zajmujących się prognozowaniem rozwoju stosunków międzynarodowych ${ }^{14}$. Narady toczą się wokół ksenofobicznych nastrojów wobec Chińczyków głównie w takich krajach jak Zambia, Etiopia i Algieria. Winni tego stanu rzeczy są poszukujący pracy chińscy imigranci, którzy chętnie podejmują się wszelkich zajęć za konkurencyjnie niskie wynagrodzenie w stosunku do miejscowej ludności. Często bywają oskarżani, zwłaszcza przez amerykańskich badaczy problematyki, o neokolonizację państw, w których znaleźli się. Z kolei przeczą temu nakłady i inwestycje Chin w krajach ubogich w złoża surowców jak Rwanda ${ }^{15}$.

13 L. Kuo, Rwanda is a landlocked country with few natural resources. So why is China investing so heavily in it?, https://qz.com/africa/827935/ rwanda-is-a-landlocked-country-with-few-natural-resources-so-why-is-china-investing-so-heavily-in-it/ [dostęp: 19.08.2019].

14 Jak stwierdził Tidiane N’Diaye, większość analityków ocenia negatywnie konsekwencje chińskiej polityki w Afryce. Szerzej: T. N’Diaye, Żótte i czarne: historia chińskiej obecności w Afryce, Warszawa 2016, s. 195-196.

15 Rwanda jest małym krajem, pozbawionym dostępu do morza, posiada niewiele zasobów naturalnych, a przy populacji około połowy tej z Pekinu oferuje znikomy nowy rynek dla chińskich produktów. Szerzej: V. Byusa, Chinese external assistance to Rwanda, „NUR - Rwanda Journal” 2010, 
Zachodni politycy i ekonomiści oskarżają Chiny, że te pogrążają państwa afrykańskie w długach i uzależniają je od współpracy z Państwem Środka. Zdaniem wielu chińskie inwestycje zagrażają budowie afrykańskiego dobrobytu i suwerenności poszczególnych państw. Kontrowersyjna bywa również jakość chińskich projektów. Przykładowo w Rwandzie od 2011 r. budowano coraz więcej klubów nocnych i kawiarni przy użyciu chińskich materiałów niespełniających standardów bezpieczeństwa. W 2012 r. władze rwandyjskie dokonały kontroli 84 budowli, które uznano za niespełniające standardów bezpieczeństwa. W kolejnym roku było ich już 120. Dochodzenia wskazały, że instalacje elektryczne w przedmiotowych obiektach nie spełniały norm bezpieczeństwa, częstokroć były przestarzałe lub niewłaściwie instalowane.

Podkreślić należy, że lokalne firmy budowlane nie są w stanie konkurować z chińskimi. Większość dużych projektów budowlanych i infrastrukturalnych jest realizowana przez chińskich kontrahentów. Chińskie firmy wygrywają duże przetargi ze względu na połączenie niskich kosztów budowy z ogromnymi możliwościami technicznymi i finansowymi. Oferują niskie ceny, ponieważ importują większość materiałów i sprzętu od swych chińskich partnerów, którzy dostarczają im materiały po niskich cenach. Przykładowo, w przetargu rządowym na budowę hangaru na międzynarodowym lotnisku w Kigali wygrała korporacja China Star licytując 1,2 mln dolarów. Dwie inne lokalne firmy: Real Constructors Ltd i Horizon Construction, spółka zależna Horizon Group, złożyły oferty o wysokości odpowiednio 1,8 mln dolarów i $3 \mathrm{mln}$ dolarów ${ }^{16}$. Chińskie firmy budowlane bywają oskarżane o nadużycia w procedurach przetargowych. Obniżona wartość projektu częstokroć wynika

vol. 19, s. 66-83.

16 D. Nzohabonimana, op.cit. 
z redukcji kosztów, które wpływają na jakość projektów ${ }^{17}$.

W centrum Kigali chińska siła robocza jest wykorzystana do budowy centrów handlowych i hoteli. Hotel Kigali Marriot to jeden z projektów przyznanych chińskim wykonawcom. Amerykańska sieć hotelowa w marcu 2011 r. podpisała umowę partnerską z rządem Rwandy i korporacją New Century Development Limited z Chin odpowiadającą za budowę hotelu. Większość materiałów do budowy została przywieziona z Chin, z wyjątkiem cementu pochodzącego z Ugandy i kilku lokalnych materiałów, takich jak drewno i cegły, które to towary są tanie i transportowanie ich z Chin byłoby kosztowne ${ }^{18}$.

Trudno konkurować z chińskimi firmami uzyskującymi dostęp do taniego kapitału. Źródłem ich zdolności finansowych są banki macierzyste, które udzielają im pożyczek o bardzo niskim oprocentowaniu. Wei Heng, dyrektor operacyjny China Star Construction Co. Ltd, stwierdził, że jego firma ma dostęp do chińskich banków oferujących kredyty oprocentowane w wysokości $8 \%$. Lokalne firmy w rwandyjskie muszą czynić niemałe zabiegi, aby uzyskać kredyty, a kiedy już je otrzymują, to obciążone wysokimi stopami procentowymi, które wynoszą od 17\% do $18 \%{ }^{19}$. Trudno jest również nadzorować chińskie korporacje, aby przestrzegały warunków przetargów, ponieważ w celu maksymalizacji zysków często stosują materiały niespełniające norm, które nie były określone w warunkach składanych ofert.

Mimo wielu kontrowersji Afrykanie, a zwłaszcza Rwandyjczycy, chętnie współpracują z Chińczykami w sektorze rozwoju rolnictwa ${ }^{20}$. Po kryzysie cen żywności w latach 2007-2008 naukowcy zajmujący się systemami żywności zaczęli spekulować, że Chiny zagarniają ziemię za oceanem, aby zabezpieczyć
17 Ibidem.
18 Ibidem.
19 Ibidem.
20 Ł. Firmanty, op.cit., s. 151. 
zasoby żywności na przyszłość. Pojawił się argument, że Chiny próbują zagarnąć ziemię w Afryce, aby tam forsować produkcję żywności. Z kolei Chińczycy wykorzystują udzielaną pomoc w rolnictwie jako sposób wejścia w afrykańskie sektory rolnicze i w ten sposób chcą uzyskać preferencyjny dostęp do lokalnych rynków zbytu produkcji rolnej ${ }^{21}$.

Kraje afrykańskie, w tym Rwanda i Uganda, są zainteresowane budowaniem partnerstw rolnych z Chinami. Isaac Lawthe stwierdził, że państwa te starają się współpracować z Chinami, ponieważ Chiny prezentują w ofertach takie technologie rolnicze, które umożliwiają tym państwom wdrażanie ich krajowych planów rozwoju rolnictwa. Chińczycy oferują tanie maszyny rolnicze, proste w obsłudze i znacznie bardziej ekonomiczne w eksploatacji od tych z Zachodu. Technologia jest dostosowana do miejscowych potrzeb. Na przykład kombajny kupowane w Europie i Stanach Zjednoczonych są drogie, wyposażone w nowoczesne technologie stwarzające lokalnej ludności problemy w toku użytkowania, a ponadto spalają setki litrów paliwa. Co więcej, chińskie technologie upraw rolnych, jak i hodowli zwierząt są bliższe lokalnym stylom życia. Przykładowo hodowla ryb w Chinach związana jest z tamtejszą tradycją produkcji hodowlanej tego typu bliską rwandyjskiej. Zatem Chiny proponują technologie odpowiednie dla rwandyjskich obszarów wiejskich ${ }^{22}$.

Kolejny problem stanowi oskarżenie państw zachodnich, że Pekin próbuje uzależnić państwa afrykańskie poprzez ich narastające zadłużenia za realizowane przez Chińczyków projekty infrastrukturalne i udzielane pożyczki. Zdaniem Pekinu są to zarzuty bezpodstawne. Chiny zagrożone są utratą udzielanych

21 I. Lawther, Why African countries are interested in building agricultural partnerships with China: lessons from Rwanda and Uganda, "Third World Quarterly" 2017, nr 38 (10), 2312-2329, s. 1-18.

22 Ibidem. 
pożyczek na skutek zubożenia wielu państw afrykańskich, które muszą przeciwstawiać się taryfom handlowym, ograniczeniom i różnego rodzaju zakazom narzucanym przez Stany Zjednoczone i ich sojuszników. Chińskie korporacje pomagają wzmocnić szlaki handlowe w rozwijających się częściach świata. W interesie Państwa Środka leży utrzymanie zrównoważonego i stabilnego wzrostu w Afryce ${ }^{23}$. Wspieranie rozwoju szlaków handlowych i sposobów dostaw w rozwijających się częściach świata jest korzystne dla obu stron.

Chińska pomoc koncentruje się głównie na projektach infrastrukturalnych. Z kolei Zachód jest na ogół niechętny udzielaniu pomocy w finansowaniu infrastruktury, mimo pilnych potrzeb kraju w tym zakresie. Co więcej ChRL oferowało pomoc bez stawiania warunków typowych dla państw zachodnich jak poprawa stanu w zakresie respektowania praw człowieka, budowa silnego systemu ekonomicznego, realizacja polityki przyjaznej środowisku itp. W podzięce za pomoc państwa, takie jak Rwanda, wspierały Chiny by odzyskały należne im miejsce w Organizacji Narodów Zjednoczonych (ONZ) i w Radzie Bezpieczeństwa ONZ (RB ONZ).

Chiński ambasador w Rwandzie Shu Zhan powiedział: „Dasz człowiekowi rybę a nakarmisz go na jeden dzień. Nauczysz go łowić a nakarmisz go na całe życie”. Rwandyjczycy mocno wierzą, że ich ojczyzna dzięki pomocy zagranicznej i zagranicznym inwestorom, wkrótce pokona bariery ubóstwa i stanie się państwem wysoko rozwiniętym ${ }^{24}$. Paul Kagame stwierdził, że Chińczycy przynoszą to, czego potrzebuje Afryka: inwestycje i pieniądze dla rządów i firm. Prezydent powiedział: „wolałbym,

23 China must allay any debt-trap fears in its dealings with Africa, https://www.scmp.com/comment/opinion/article/3017478/china-must-allay-any-debt-trap-fears-its-dealings-africa [dostęp: 5.01.2020].

24 China praised for African links, http://news.bbc.co.uk/2/hi/africa/8301826.stm [dostęp: 13.11.2019]. 
aby świat zachodni inwestował w Afryce, a nie udzielał pomocy rozwojowej. Potrzebna jest pomoc - ale powinna być wdrożona w taki sposób, aby umożliwić handel i budować firmy. Wysokie taryfy handlowe uniemożliwiły afrykańskim producentom uzyskanie sprawiedliwego dostępu do światowych rynków. Pomogłoby to Afryce o wiele bardziej, gdyby państwa uprzemysłowione pozwoliły nam na takie same prawa handlowe, jakie dają sobie nawzajem ${ }^{25}$.

Podsumowując, Rwanda uważa Chiny za wzór rozwoju gospodarczego. Jest to model, który stawia w pozycji uprzywilejowanej stabilność i wzrost gospodarczy w stosunku do swobód osobistych i społecznych. Rugaba Silas, ambasador Rwandy w Chinach w 1995 r. ogłosił, że Rwanda dąży do wyciągnięcia wniosków z chińskich doświadczeń w przezwyciężeniu trudnej przeszłości lat wojny domowej, głodu, ubóstwa i fanatycznej rewolucji kulturalnej. W praktyce Rwanda przyjęła pewne wątpliwe praktyki, które można było zobaczyć również w Chinach. Rząd rwandyjski jest oskarżany o ignorowanie praw człowieka i pozorną likwidację ubóstwa, a nie jego korzeni. Human Rights Watch w raporcie na początku 2016 r. stwierdził, że policja gromadzi i przetrzymuje bezdomnych, dzieci ulicy, domokrążców w „ośrodkach tranzytowych”, gdzie często są bici ${ }^{26}$.

25 Opinię Paula Kagame podziela zambijska ekonomistka Dambisa Moyo, krytykując zachodnią pomoc dla Afryki. D. Moyo, Dead Aid. Why Aid is Not Working and How there is another way for Africa, New York, 2010, s. 29-47; China praised for African links, http://news.bbc.co.uk/2/hi/ africa/8301826.stm [dostęp: 13.11.2019].

26 Między innymi David Himbara, jako zagorzały przeciwnik i krytyk Paula Kagame, podważa doniesienia o silnym rozwoju Rwandy, stwierdzając, że mimo iż Rwanda się rozwija niektóre statystyki są przesadzone. Himbara podważa raporty Banku Światowego, który stwierdził, że środowisko biznesowe Rwandy rozwija się lepiej niż Szwajcarii, Holandii, Francji, Japonii czy Belgii. David Himbara, World Bank Says Rwanda Is Better Than Switzerland, Netherlands, France, Japan, Belgium, And China In Business Environment, http://www.therwandan.com/world-bank-says-rwanda-is-better-than-swit- 
Zaangażowanie Chin w Rwandzie odbywa się na zasadzie nieingerencji w kwestie polityczne oraz koncentruje na wzajemności korzyści, jakie oba państwa mogą uzyskać dzięki wymianie handlowej, współpracy inwestycyjnej i gospodarczej ${ }^{27}$. Głównie ze względu na zasadę nieingerencji w wewnętrzne sprawy państw afrykańskich, Chiny są oskarżane o lekceważenie przejawów łamania praw człowieka i zasad demokracji oraz wspieranie autorytarnych reżimów ${ }^{28}$. Współpraca gospodarcza Rwandy i Chin przynosi wzajemne korzyści. Społeczeństwo rwandyjskie wysoko ceni sobie efekty kooperacji w sektorze rolnictwa i rybołówstwa, wprowadzane technologie, a co za tym idzie jakość produktów i ich ceny. Z drugiej zaś strony Rwandyjczycy są nieco zaniepokojeni jakością towarów sprowadzanych bezpośrednio z Chin, w przeciwieństwie do tych eksportowanych z Japonii ${ }^{29}$.

Priorytetem dla rwandyjskiego rządu jest rozwój gospodarczy kraju. W 2016 r. Rwanda uchodziła za jedną z najszybciej rozwijających się gospodarek na kontynencie i chce uchodzić za centrum biznesowe i technologiczne Afryki. Poprzez inwestycje ma nadzieję na odchodzenie od pomocy zagranicznej, która jeszcze w 2016 r. stanowiła prawie 40\% jej rocznego budżetu $^{30}$. Długoterminową ścieżkę rozwoju dla Rwandy, jej cele ekonomiczno-gospodarcze do 2020 r. zdefiniowano w dokumencie „Rwanda Vision 2020” sporządzonym przez Ministerstwo Finansów i Planowania Gospodarczego Rwandy ${ }^{31}$. Plan

zerland-netherlands-france-japan-belgium-and-china-in-business-environment/ [dostęp: 15.01.2020].

27 J. Gu, A. Carty, op.cit., s. 57-69;

28 Ibidem.

29 V. Byusa, op.cit., s. 66-83.

30 L. Kuo, op.cit.; Ministry of Foreign Affairs and International Cooperation, https://www.minaffet.gov.rw/index.php?id=12 [dostęp: 19.08.2019].

31 Dokument rządowy sporządzony przez Ministerstwo Finansów i Planowania Gospodarczego w Rwandzie: D. Karebuka, Rwanda Vision 2020, 
określa ramy rozwoju Rwandy, przedstawiające priorytetowe kierunki rozwoju dla państwa.

W wyniku badań przeprowadzonych w Rwandzie w grudniu 2018 r., rozmów z przedstawicielami miejscowej administracji oraz obserwacji życia codziennego w tym kraju, autorka niniejszego artykułu formułuje następującą opinię. Otóż bez względu na sprzeczne oceny analityków i naukowców, co do rozwoju gospodarczego i sposobów zarządzania państwem, w porównaniu z państwami ościennymi, rząd w Kigali potrafi zapewnić i utrzymać bezpieczeństwo granic, a społeczeństwo ewoluuje w kierunku tworzenia silnego i zjednoczonego narodu, dumnego ze swoich dokonań i respektującego podstawowe wartości społeczne.

\section{Bibliografia}

Bar J., Po ludobójstwie: państwo i społeczeństwo w Rwandzie 1994-2012, Kraków 2013.

Bar J., Rwanda, Warszawa 2013.

Byusa V., Chinese external assistance to Rwanda, „NUR Rwanda Journal" 2010, vol. 19.

Chretien Jean-Pierre, The Great Lakes of Africa. Two thousand Years of History, tłum. S. Straus, New York 2006.

Firmanty Ł., Afryka we wspótczesnej polityce Chińskiej Republiki Ludowej, Toruń 2013.

Gu J., Carty A., China and African Development: Partnership not Mentoring, „IDS Bulletin” 2014, vol. 45, nr 4.

Kamakshi Nanda, New 'Friends' of Rwanda-Chinese Noodles and Indian Curry: An Analysis of Asian Giants' Forays into Rwanda in the Light of Theories on OFDI, [w:] Rwanda Fast

„Republic of Rwanda. Ministry of Finance and Economic Planning”, Kigali 2000, s. 1-31, https://www.sida.se/globalassets/global/countries-and-regions/africa/rwanda/d402331a.pdf [dostęp: 14.11.2019]. 
Forward, red. M. Campioni et al., London 2012.

Karebuka Donald, Rwanda Vision 2020, „Republic of Rwanda.

Ministry of Finance and Economic Planning", Kigali 2000.

Lawther Isaac, Why African countries are interested in building agricultural partnerships with China: lessons from Rwanda and Uganda, „Third World Quarterly” 2017, nr 38 (10). Minaffet Ministry of Foreign Affairs and Cooperation, The Diplomatic Magazine. Ministry of Foreign Affairs and International Cooperation, Kigali 2009.

Moyo D., Dead Aid. Why Aid is Not Working and How there is another way for Africa, New York, 2010.

N’Diaye T., Żótte i czarne: historia chińskiej obecności w Afryce, tłum. E. Brzozowska, Warszawa 2016.

\section{Netografia}

www.minaffet.gov.rw.

www.paulkagame.com.

www.pambazuka.org.

www.therwandan.com.

www.sida.se.

www.msn.com.

www.scmp.com.

www.news.bbc.co.uk.

www.qz.com/africa.

\section{Abstrakt}

Obecność Chin w Rwandzie, po nawiązaniu stosunków dyplomatycznych w 1971 r., ma dwa wymiary. Po pierwsze, Państwo Środka pośrednio miało wpływ na tragiczny przebieg konfliktu o cechach ludobójstwa w 1994 r. Chiny, podobnie jak Francja, były odpowiedzialne za zaopatrywanie rządu Rwandy w broń i inne materiały wojskowe niezbędne do prowadzenia działań wojennych. Po drugie, po zakończeniu wojny domowej Rwanda potrzebowała pomocy, aby odbudować kraj ze zniszczeń. Chińska Republika Ludowa, jako jedno z pierwszych 
państw, pospieszyła z pomocą. Od tego czasu przyjaźń Chin i Rwandy zaowocowała różnymi inicjatywami, głównie w sektorze gospodarczym. W raporcie Banku Światowego z 2016 r. Rwandę uznano za najłatwiejszy kraj dla biznesu wśród państw Afryki Subsaharyjskiej oraz lidera Afryki Wschodniej. Wizja rozwoju Rwandy jest koordynowana przez konsorcja planistyczne USA i Singapuru oraz finansowana i realizowana częściowo przez chińskich wykonawców.

Słowa kluczowe: Chiny, Rwanda, polityka, gospodarka

\begin{abstract}
The presence of China in Rwanda, since the establishment of diplomatic relations in 1971, has existed within two main dimensions. First of all, China was indirectly involved in the tragic events during the genocidal conflict in 1994. China and France were responsible for supplying the government of Rwanda with weapons and other war material, essential for military activities. Second of all, after the end of the civil war, Rwanda required assistance in order to rebuild the devastated country. The People's Republic of China was among the first countries in the world that offered help. Since then, the friendship between China and Rwanda has resulted in a variety of activities, mainly in the field of economy. In the report prepared by the World Bank in 2016 Rwanda was considered to be the easiest country for business among all the countries in the region of Sub-Saharan Africa and the leader in Eastern Africa. The vision of the development of Rwanda is coordinated by planning consortia in the USA and Singapore and financed and partially implemented by Chinese contractors.
\end{abstract}

Keywords: China, Rwanda, politics, economic 


\section{Marcin Czyżniewski}

Uniwersytet Mikołaja Kopernilka w Toruniu

ORCID ID: https://orcid.org/0000-0002-3227-0035

\section{Kwestia Tybetu w stosunkach czesko-chińskich}

W ostatnich latach Chiny stały się jednym z najważniejszych partnerów w stosunkach międzynarodowych. Są producentem i rynkiem zbytu o ogromnym potencjale, przykłady chińskich inwestycji znaleźć można na całym świecie. Znacząco wzmacnia się także polityczna pozycja Chin. Jednak rozwojowi współpracy towarzyszą niezmiennie kontrowersje związane z problemem ochrony praw człowieka w Chinach, w tym z sytuacją w Tybecie. Polityczni i gospodarczy partnerzy Chin nie wypracowali spójnej strategii wobec tego problemu, wciąż jest ona zależna od zmian politycznych w poszczególnych państwach.

Tybet został zajęty przez wojska chińskie w 1950 r., a rok później został włączony do Chińskiej Republiki Ludowej (od 1965 r. jako Tybetański Okręg Autonomiczny). Zaostrzenie sytuacji politycznej w tym regionie nastąpiło po stłumieniu antychińskiego powstania w regionie w 1959 r. Dalajlama wraz z tysiącami rodaków przedostał się do Indii, gdzie utworzył tybetański rząd emigracyjny. Represjom wobec mnichów tybetańskich i obieraniu klasztorom ziemi towarzyszyła chińska akcja osadnicza i przymusowe narzucanie kultury chińskiej ${ }^{1}$. Kwestia Tybetu podejmowana jest odtąd przez organizacje i fundacje pozarządowe, ale także przez polityków, parlamen-

1 Szerzej: K. Kubiak, Tragedia Tybetu a strategii rozwojowa Chin, „Rocznik Bezpieczeństwa Międzynarodowego" 2008, s. 95-99; R.E. McCarthy, Tears of the Lotus. Accounts of Tibetan Resistance to the Chinese Invasion, 1950-1962, Jefferson 1997, s. 216-225. 
ty i rządy krajowe. Oskarżenia wobec władz w Pekinie dotyczą m.in. stosowania represji, w tym kary śmierci, więzienia i tortur wobec mieszkańców Tybetu, brutalnego tłumienia pokojowych demonstracji, nieprzestrzegania praw politycznych formalnie gwarantowanych w chińskiej konstytucji, przymusowych przesiedleń, marginalizacji ekonomicznej Tybetu i ograniczania tożsamości kulturowej i religijnej jego mieszkańców ${ }^{2}$.

Jednym z najważniejszych partnerów Chin jest Unia Europejska. Relacje gospodarcze rozwijają się dynamicznie od 1978 r., gdy podpisano porozumienie handlowe między Chińską Republiką Ludową i ówczesną Europejską Wspólnotą Gospodarczą. Jednak już w 1989 r. kwestia praw człowieka w istotny sposób wpłynęła na rozwój tych kontaktów - po masakrze na placu Tiananmen EWG nałożyła na Chiny sankcje ekonomiczne obejmujące zawieszenie kontraktów na broń i sprzęt wojskowy oraz pożyczek z gwarancjami rządowymi³

Sytuacja w Tybecie jest częstym tematem dyskusji w Parlamencie Europejskim. Eurodeputowani wielokrotnie zabierali głos w tej sprawie, m.in. wzywając Komisję Europejską i państwa członkowskie do podnoszenia kwestii Tybetu w kontaktach z władzami ChRL, sprzeciwiając się stosowaniu tortur wobec tybetańskich więźniów politycznych i podejmując akcje na rzecz ich uwolnienia, domagając się zgody na inspekcje międzynarodowe w miejscach odosobnienia, żądając poprawy warunków życia Tybetańczyków, w tym dostępu do edukacji i opieki zdrowotnej, wreszcie nagłaśniając konkretne przypadki łamania praw człowieka w Tybecie ${ }^{4}$.

2 Zob. Z. Filipiak, Zarys praktyki praw człowieka $w$ Tybecie, „Studia Iuridica Torunensia" 2006, s. 61-88.

3 T. Sporek, Analiza stosunków handlowych pomiędzy Chińską Republika Ludowa a Unią Europejska, „Studia Ekonomiczne. Zeszyty Naukowe Uniwersytetu Ekonomicznego w Katowicach” 2012, s. 23.

4 K. Gorgol, Kluczowe problemy polityczne w dialogu Unii Europejskiej z Chińskq Republika Ludowq u progu XXI wieku, "Forum Politologiczne” 
Dla państw utrzymujących stosunki polityczne i gospodarcze z Chińską Republiką Ludową, niezależnie od ich wymiaru, jak i własnej pozycji w polityce międzynarodowej, kwestia Tybetu nie stanowi dylematu w wymiarze dyplomatycznym. Żadne z liczących się państw nie zdecydowało się na zamrożenie kontaktów z jedną z największych potęg współczesnego świata, by wymusić istotne ustępstwa wobec Tybetu i jego mieszkańców. Tybet stanowi raczej pewną „zadrę” w realizowaniu polityki wobec ChRL, mniej chodzi tu o Tybet jako taki, stał się on jedynie symbolem polityki, w której istnieje jeszcze coś ponad partykularne interesy, polityczny i ekonomiczny pragmatyzm, a żaden z demokratycznych rządów nie chce być postrzegany przez swoich obywateli jako pozbawiony wrażliwości i sumienia w sytuacji łamania podstawowych praw człowieka i obywatela.

Dyskusja dotycząca Tybetu i jego miejsca w relacjach z Chinami toczy się od dekad także w Republice Czeskiej. Nie należy jej jednak stawiać $\mathrm{w}$ równym rzędzie z podobnymi dyskusjami toczonymi w innych państwach i społeczeństwach. Znaczenie tej dyskusji wyrasta bowiem poza wymiar kontaktów niedużego państwa środkowoeuropejskiego ze światową potęgą. Sprawa Tybetu stała się dla Czechów jednym z najważniejszych elementów dwóch skrajnych wizji polityki międzynarodowej, a może nawet polityki w ogóle. Za sprawą własnych doświadczeń historycznych Tybet jest dziś w Republice Czeskiej symbolem konfliktu między polityką zbudowaną na uniwersalnych ideach i wartościach a realizującą wyłącznie interesy gospodarcze i polityczne.

Za sprawą symbolicznego znaczenia Tybetu w czeskiej polityce jest on wyjątkowo wyraźny w przestrzeni publicznej, a wiele działających w niej osób, zarówno polityków, jak i saParlamentu Europejskiego, „Studia Europejskie” 2008, nr 2, s. 147-153. 
morządowców, artystów czy naukowców, deklaruje swoje stanowisko w tej kwestii. Aktywne są organizacje pozarządowe i fundacje, w tym czeski oddział Amnesty International, stowarzyszenia Lungta, Most i Potala, organizujące akcje, wystawy, koncerty, prowadzące strony internetowe i wydające publikacje poświęcone Tybetowi. Flagi Tybetu podczas corocznej akcji upamiętniającej rocznicę antychińskiego powstania pojawiają się także na budynkach publicznych i państwowych, w tym na urzędach gmin i uczelniach.

Tybet budził zainteresowanie Czechów jeszcze w okresie międzywojennym, niezależnie od kontekstu politycznego i międzynarodowego. Chociaż wiedza o nim i jego mieszkańcach była wówczas niewielka, stał się symbolem ziemi mistyków i magów ${ }^{5}$. Symbolika ta trafiała na podatny grunt zwłaszcza w Pradze, przepełnionej od stuleci atmosferą magii i alchemii. Polityczny kontekst nadszedł w 1959 r., wraz z wybuchem w Tybecie powstania antychińskiego. Komunistyczna prasa w Czechosłowacji poświęcała temu wydarzeniu zaskakująco dużo miejsca, choć, oczywiście, prezentowała jednoznacznie chiński punkt widzenia 6 .

Po 1989 r. Tybet wpisał się w działania Czechosłowacji, a następnie Republiki Czeskiej, aktywnie zabierającej głos w przypadkach łamania praw człowieka i praw obywatelskich czy gwałcenia porozumień międzynarodowych. Czechy trzykrotnie próbowały wprowadzić na forum ONZ projekt rezolucji krytykującej Kubę za prześladowania opozycji, reagowały na wydarzenia w Czeczenii i działania reżimu w Korei Północnej. W 2002 r. uruchomiono w Pradze nadające w języku perskim Radio Farda, finansowane przez rząd Stanów Zjednoczonych, czego efektem był bojkot czeskich towarów utrzymywany przez

5 Szerzej: J. Rozehnalová, Zrcadlo orientalismu-obrazy Tibetu v českém prostředi, „Mezinárodní vztahy” 2005, nr 3, s. 51-52.

6 Ibidem, s. 55. 
władze Iranu w latach 2003-2007. W 2002 r., mimo nacisków ze strony sekretarza generalnego NATO, Republika Czeska nie zgodziła się na wydanie wizy prezydentowi Białorusi Aleksandrowi Łukaszence, uniemożliwiając mu udział w szczycie sojuszu w Pradze. Problem z Łukaszenką powrócił w trakcie czeskiej prezydencji w Unii Europejskiej w 2009 r., gdy organizowano szczyt inaugurujący Partnerstwo Wschodnie - obecność Łukaszenki na szczycie Unii byłaby symbolicznym przełamaniem izolacji białoruskiego reżimu. Czeski minister spraw zagranicznych, Karel Schwarzenberg, wystosował ostatecznie zaproszenie, ale uczynił to dopiero po tym, gdy Białoruś zasygnalizowała, że sam Łukaszenko nie weźmie udziału w szczycie, delegując swojego przedstawiciela ${ }^{7}$.

W przyjętej w 1998 r. koncepcji polityki zagranicznej Republiki Czeskiej prawom człowieka nadano istotny wymiar. W dokumencie czytamy: „Kwestia praw człowieka jest często postrzegana jako nazbyt idealistyczna część polityki zagranicznej, stanowiąca wręcz przeszkodę w pragmatycznych stosunkach ekonomicznych. Republika Czeska stoi na stanowisku, że istnienie dialogu politycznego o prawach człowieka jest miarą wiarygodności a z dłuższej perspektywy i szans na rozwój kontaktów gospodarczych z danym państwem. Republika Czeska chce być w tej kwestii otwarta i transparentna. Wychodzi z założenia, że rzeczowa dyskusja o prawach człowieka w dzisiejszym wielokulturowym świecie jest, z punktu widzenia przyszłości, najlepszą inwestycją" ${ }^{8}$.

Silne akcentowanie kwestii praw i wolności w polityce międzynarodowej to dziedzictwo ruchu dysydenckiego. Kwestie

7 M. Czyżniewski, K. Witkowska-Chrzczonowicz, Prezydencja Republiki Czeskiej w Radzie Unii Europejskiej: studium prawno-politologiczne, Warszawa 2011, s. 302-303.

8 Koncepce zahraniční politiky České republiky, https://www.vlada.cz/ $\mathrm{cz} /$ clenove-vlady/historie-minulych-vlad/!-koncepce-zahranicni-politikyceske-republiky-2156/\#44. 
międzynarodowe znajdowały się na marginesie działalności czechosłowackiej opozycji, odnosząc się z reguły do kontekstu krajowego (np. miejsca Czech w Europie, stosunków czesko-niemieckich, roli Czechosłowacji i innych państw komunistycznych w międzynarodowym systemie ochrony praw człowieka $)^{9}$. Kwestia Chin pojawiła w dyskursie opozycyjnym tuż przed aksamitną rewolucją, w reakcji na masakrę na placu Tiananmen. Jednak najważniejszym elementem dziedzictwa ruchu dysydenckiego było podejście do polityki jako takiej czy szerzej: do stosunków społecznych w ogóle. Dysydenci, rekrutujący się przede wszystkim z inteligencji, szeroko dyskutowali o roli moralności i wartości w przestrzeni publicznej, podkreślając, że polityka musi opierać się na prawdzie. W okres przemian politycznych po 1989 r. wnieśli także przekonanie, że przeszłość komunistyczna stanowi zobowiązanie, by ci, którzy wyzwolili się z ucisku solidarnie pomagali tym, którzy go wciąż doświadczają ${ }^{10}$. Akcenty te były wyraźnie widoczne w publicystyce Václava Havla, który w grudniu 1989 r. został pierwszym niekomunistycznym prezydentem Czechosłowacji od 41 lat.

Po aksamitnej rewolucji dysydenci objęli szereg istotnych stanowisk w państwie, także w dyplomacji. Pierwszym czechosłowackim ministrem spraw zagranicznych po 1989 r. został Jiří Dienstbier, sygnatariusz Karty'77, bliski współpracownik Václava Havla, prześladowany przez komunistów za działalność opozycyjną. To właśnie otoczenie prezydenta Havla nadawało w pierwszej połowie lat 90. ton polityce zagranicznej Czechosłowacji i Republiki Czeskiej, tym bardziej, że rząd kierowany od 1992 r. przez Václava Klausa, który sam nie dzia-

9 Szerzej: Š. Waisová, Tihá volby, Česká zahraniční polityka mezi principy a zajmy, Praha 2011, s. 72-75.

10 R. Fürst, Podpora Tibetu, Tchaj-wanu a lidských práv v Číně: Evropská avantgarda neb český kýč?, [w:] Hledání českých zajmu: obchod, lidksá práva a mezinárodní rozvoj, red. P. Drulák, O. Horký, Praha 2010, s. 92-93. 
łał w ruchu dysydenckim, skupiał się na sprawach wewnętrznych, zwłaszcza na reformach gospodarczych ${ }^{11}$. Kwestia praw człowieka, obok jednoznacznego poparcia dla europejskich procesów integracyjnych, była najważniejszym rysem polityki zagranicznej Havla ${ }^{12}$.

Podkreślić trzeba, że nie wszyscy dysydenci prezentowali w późniejszych latach tak jednoznaczne stanowisko, także w kontekście Chin i Tybetu. Gdy Pekinowi powierzono organizację Igrzysk Olimpijskich w $2008 \mathrm{r}$. jeden z czołowych działaczy ruchu dysydenckiego, Petr Uhl, w artykule opublikowanym w dzienniku „Právo” (dawnym organie $\mathrm{KC} \mathrm{KPCz}$ ) przewidywał, że Igrzyska będą mieć pozytywny wpływ na rozwój praw człowieka w Chinach, zapewniając, że życie polityczne w tym kraju już ulega liberalizacji, pogłębia się pluralizm poglądów i zwiększa wolność słowa ${ }^{13}$.

Niezależnie od kwestii Tybetu, Republika Czeska i Chiny rozwijały swoje stosunki polityczne i gospodarcze zapoczątkowane w 1919 r. otwarciem konsulatu Czechosłowacji w Szanghaju. Pierwsze oficjalne spotkanie czesko-chińskie po aksamitnej rewolucji miało miejsce na początku 1991 r., gdy w Pradze spotkali się wiceministrowie spraw zagranicznych obu państw. Wkrótce do Pragi przyjechał chiński minister handlu zagranicznego, a kilka miesięcy później prezydent Havel przyjął ministra spraw zagranicznych (w trakcie spotkania nie poruszano sprawy Tybetu). Jesienią 1991 r. czechosłowacki premier Marian Čalfa udał się z delegacją do Pekinu, gdzie został przyjęty przez najwyższych przedstawicieli państwa i partii ${ }^{14}$. Tylko

11 Š. Waisová, op.cit., s. 86-88.

12 M. Kořan, M. Hrabálek (red.), Česká zahraniční politika: aktéři, struktura, proces, Brno 2007, s. 35.

13 R. Fürst, Politické vnímání Číny v Čechách, mezi věcností a nevěcností, orientalismem a okcidentalismem. „Mezinárodní vztahy” 2005, nr 3, s. 33.

14 R. Fürst, Česko-čínské vztahy po roce 1989, Praha 2010, s. 43-44. 
w latach 90. XX w. doszło do siedmiu wzajemnych wizyt na szczeblu co najmniej ministerialnym ${ }^{15}$. Pierwsza wizyta prezydenta Republiki Czeskiej w Chinach miała miejsce w 2004 r., jednak Przewodniczący Chińskiej Republiki Ludowej odwiedził Republikę Czeską dopiero w roku 2016 r.

Temat Tybetu pojawił się w wielkiej polityce czeskiej tuż po upadku komunizmu. Pierwsze noworoczne przemówienie prezydenta Havla poświęcone było m.in. konieczności przywrócenia wartości moralnych w polityce. W tym kontekście Havel zapowiedział, że chciałby zaprosić do Czechosłowacji papieża Jana Pawła II i dalajlamę ${ }^{16}$. Przemówienie to wygłosił kilka miesięcy po masakrze na placu Tiananmen i krótko po otrzymaniu przez duchowego przywódcę Tybetu Pokojowej Nagrody Nobla. Czechosłowacki prezydent był pierwszą głową państwa, która zaprosiła dalajlamę do swojego kraju.

XIV Dalajlama przyjechał do Pragi już miesiąc później, na początku lutego 1990 r. (także papież odwiedził Czechosłowację jeszcze wiosną 1990 r.). Wizyta miała prywatny charakter, a w jej trakcie dalajlama spotkał się nie tylko z Havlem, ale także z prymasem Czech, kardynałem Františkiem Tomáškiem ${ }^{17}$. Wizyta wywołała oficjalny protest chińskiej ambasady. Od tego czasu XIV Dalajlama odwiedzał Pragę wielokrotnie, m.in. w latach 1997, 2000, 2002, 2003, 2006, 2008, 2009 i $2011^{18}$.

Havel do końca życia zabierał głos w sprawach Tybetu. W 2009 r. publicznie skrytykował prezydenta USA Baracka Obamę, który otrzymał właśnie Pokojową Nagrodę Nobla, za

15 F. Zbořil, Československá a česká zahraniční politika: minulost a současnost, Praha 2010, s. 409-410.

16 Novoroční projev prezidenta ČSSR Václava Havla, 1.01.1990, http:// vaclavhavel.cz/showtrans.php?cat=projevy\&val=327_projevy.html\&typ= HTML.

17 M. Žantovský, Havel, Praha 2014, s. 402-404.

18 F. Zbořil, op.cit., s. 412-413. 
to, że nie spotkał się z dalajlamą (uczynił to dopiero po złożeniu oficjalnej wizyty w Chinach $)^{19}$. Symboliczny był fakt, że ostatnią osobą, z którą Havel spotkał się przed śmiercią (grudzień 2011 r.) był właśnie duchowy przywódca Tybetu. Ani w trakcie swojej prezydentury (1989-1992 i 1993-2003), ani potem Václav Havel nie złożył wizyty w Chinach.

Kwestia Tybetu i przestrzegania praw człowieka w Chinach była wielokrotnie poruszana na forum czeskiego parlamentu. W 1996 r. w Izbie Poselskiej powstała specjalna grupa deputowanych zajmująca się tymi kwestiami, a kilka lat później zawiązała się Grupa Przyjaciół Tybetu, skupiająca parlamentarzystów z różnych opcji. W 1997 r. Komisja Spraw Zagranicznych Izby przyjęła petycję w sprawie przestrzegania praw człowieka w Chinach. Podobny dokument przyjęto w 2008 r., po zaostrzeniu się sytuacji w Tybecie. Wezwano w nim władze Chińskiej Republiki Ludowej do zaprzestania represji wobec Tybetańczyków. Gdy w tym samym roku chińska delegacja odwiedziła Izbę Poselską, deputowani z Partii Zielonych wywiesili w niej flagę Tybetu (w reakcji delegacja opuściła siedzibę parlamentu).

Prezydentura Václava Klausa (2003-2013), wielokrotnie krytykującego politykę swojego poprzednika w wielu obszarach i zarzucającego mu m.in. nadmierny idealizm w polityce, zmieniła oficjalną czeską politykę wobec Chin. Przed swoją oficjalną wizytą w Pekinie (kwiecień 2004 r.) Klaus opublikował artykuł, w którym wyjaśniał, że współpraca z Chinami, jednym z najpotężniejszych i szybko rozwijających się państw świata, leży w interesie Czech, nawet biorąc pod uwagę, że państwo to nie stosuje w polityce wewnętrznej „wyznawanych przez nas zasad pluralistycznej demokracji parlamentarnej i koncepcji praw obywatelskich w naszym rozumieniu". Dalej pisał:

19 R. Fürst, Podpora Tibetu..., op.cit., s. 94. 
„W ostatnich latach w stosunku do Chińskiej Republiki Ludowej wytworzyły się u nas dwa uproszczone punkty widzenia. Zgodnie z pierwszym, priorytet stanowią kontakty gospodarcze i szanse wykorzystania ogromnego potencjału chińskiego rynku, dlatego nie powinniśmy brać pod uwagę niczego innego, zapomnieć o prawach człowieka, nie zajmować się polityką i dbać przede wszystkim o interesy. Drugi, przeciwny pogląd zakłada, że w kontaktach z Chinami możemy trwać w lekceważącej postawie wyznawców jednej jedynej prawdy i mesjaszy praw człowieka i za jedyne dopuszczalne postępowanie przyjąć ignorowanie, pouczanie i drobne prowokacje polityczne. Jestem przekonany, że oba poglądy są błędne" ${ }^{\prime 20}$. Gdy cztery lata później część światowych przywódców zastanawiało się nad bojkotem inauguracji Igrzysk Olimpijskich w Pekinie (kilka miesięcy wcześniej doszło do brutalnej operacji chińskiej policji w Tybecie), prezydent Klaus zdecydował się zostać w kraju, jednak nie uczynił tego w atmosferze politycznej demonstracji - jego kancelaria ogłosiła, że prezydent podda się zabiegowi chirurgicznemu planowanemu wcześniej w innym terminie ${ }^{21}$.

Jednak prawdziwa zmiana nadeszła wraz z objęciem urzędu prezydenta przez Miloša Zemana, niegdyś przewodniczącego partii socjaldemokratycznej. W jego poglądach na Chiny nie ma już miejsca na jakiekolwiek dylematy czy ważenie skrajnych poglądów. Zeman zdecydowanie odrzuca idealistyczną perspektywę polityki zagranicznej, przyjmując za jej podstawę wyłącznie interesy polityczne i ekonomiczne państwa. Gdy w 2014 r. po raz pierwszy odwiedził Pekin, w wywiadzie dla chińskiej telewizji powiedział wprost, że nie zamierza udzielać lekcji jak przestrzegać praw człowieka, ale sam chce się na-

20 V. Klaus, Před návštěvou v Číně, „Mladá fronta Dnes”, 8.04.2004, http://www.klaus.cz/clanky/1762.

21 M. Kořan et al., Česká zahraniční politika v roce 2008, Praha 2009, s. 272. 
uczyć jak zapewnić stabilność społeczeństwa ${ }^{22}$. Zrozumienie dla swojej wizji znalazł wśród części polityków swojej dawnej partii tworzącej od 2013 r. koalicje rządową. W 2014 r. w komunikacie wydanym w trakcie wizyty w Chinach socjaldemokratycznego ministra spraw zagranicznych Republiki Czeskiej Lubomíra Zaorálka znalazł się akapit stwierdzający: „Strona czeska respektuje suwerenność i integralność Chińskiej Republiki Ludowej, jest w pełni świadoma jak ważna i delikatna jest kwestia Tybetu, potwierdza dochowanie swojej polityki jednych Chin i to, że Tybet jest nieodłączną częścią terytorium chińskiego. W związku z tym Republika Czeska nie wspiera niepodległości Tybetu w jakiejkolwiek formie"23. Dokument wywołał w Czechach zaskoczenie, odebrano go jako wyraźny sygnał porzucenia polityki Václava Havla nie tylko w stosunku do kwestii Tybetu. Opozycja oskarżała premiera Bohuslava Sobotkę, że sprzedał kwestię obrony praw człowieka za chińskie pieniądze. Stanowisko zaprezentowane w komunikacie potwierdził wkrótce prezydent Zeman podczas swojej wizyty w Chinach.

Równie gorącą dyskusję wywołało oświadczenie wydane w 2016 r. przez prezydenta, premiera i przewodniczących obu izb czeskiego parlamentu. Było ono reakcją na wizytę w Republice Czeskiej dalajlamy, a zwłaszcza na przyjęcie go przez ministra kultury Daniela Hermana z koalicyjnej, chadeckiej partii KDU-ČSL. Najwyżsi przedstawiciele czeskiej władzy zdecydowanie odcięli się od tego spotkania. W oświadczeniu napisano: „Nasz kraj realizując długookresową politykę wobec Chińskiej Republiki Ludowej opiera się na zasadach strategicznego part-

22 V. Bílková, Lidskoprávní rozměr české zahraniční polityki, [w:] Česká zahraniční politika v roce 2014, red. M. Kořan, Praha 2015, s. 386.

23 Tiskové prohlášení ministerstev zahraničních věcí České republiky a Čínské lidové republiky, http://www.mzv.cz/jnp/cz/udalosti_a_media/prohlaseni_a_stanoviska/x2014_04_29_tiskove_prohlaseni_ministerstev.html. 
nerstwa między obu krajami i na wzajemnym szacunku dla suwerenności i integralności terytorialnej ChRL, której częścią pozostaje Tybet (...). Indywidualna aktywność niektórych polityków czeskich nie jest wyrazem zmiany oficjalnej polityki Republiki Czeskiej i byłoby nieszczęściem, gdyby została za taką uznana" 24 . Ten bezprecedensowy, z uwagi na rangę sygnatariuszy, dokument spotkał się ze sprzeciwem ze strony opozycji i części społeczeństwa. Politycy partii TOP09 określili go jako „wstyd i poniżenie czeskich obywateli”. „Najwyżsi przedstawiciele Republiki Czeskiej pokazali jednoznacznie, że nie chcą nawiązywać do spuścizny Václava Havla i gotowi są sprzedać zasady demokracji za wizję zysków ekonomicznych, która nie jest i nie będzie spełniona"25. Głosy poparcia dla ministra Hermana oraz sprzeciwu wobec oświadczenia napłynęły także ze strony niektórych polityków koalicyjnej partii ANO, w tym wicepremiera Andreja Babiša (Babiš zresztą kilkakrotnie w swoich wypowiedziach nawiązywał do wizji polityki prezentowanej przez Václava Havla, jednak wśród komentatorów nie ma zgody czy chodzi o rzeczywisty pogląd raczej bezideowego polityka czy wyłącznie o próbę poszerzenia elektoratu). W reakcji na oświadczenie władz Republiki z dalajlamą spotkała się grupa 50 posłów i senatorów z różnych partii, a na budynkach niektórych uczelni, w tym uniwersytetów w Pradze i Brnie, oraz na siedzibie Teatru Narodowego w Pradze wywieszono tybetańskie flagi. Na oświadczenie i towarzyszącą mu dyskusję zareagowało także chińskie Ministerstwo Spraw Zagranicznych, stwierdzając m.in.: „Chiny ufają, że właściwe kraje dochowają polityki jednych Chin i będą ostrożnie pod-

24 Společné prohlášení nejvyššich ústavních činitelů České republiky, https://www.hrad.cz/cs/pro-media/tiskove-zpravy/aktualni-tiskove-zpravy/ spolecne-prohlaseni-nejvyssich-ustavnich-cinitelu-ceske-republiky-12953.

25 Prohlášení TOP 09 k návštěvě tibetského duchovního dalajlamy, http://www.top09.cz/co-delame/tiskove-zpravy/top-09-ohnout-zada-jejednoduche-21228.html. 
chodzić do spraw Tybetu tak, by zapewnić właściwy rozwój stosunków dwustronnych. Chiny cenią sobie takie zobowiązania"26.

Do sporu między ministrem Hermanem a prezydentem Republiki Czeskiej doszło już wcześniej, w marcu 2016 r., podczas wizyty w Pradze Przewodniczącego ChRL, Xi Jinpinga. Wizycie towarzyszyły nie tylko wyjątkowe środki bezpieczeństwa, ale także niezwykła oprawa. Media donosiły o przypadkach zdejmowania przez policję flag Tybetu wywieszanych z okien, a na praski zamek nie wpuszczono osób demonstrujących przeciwko wizycie. Minister Herman komentował: „Uważam, że miara serwilizmu nie była godna suwerennego państwa ze 150-letnią tradycją demokratyczną w sercu Europy. Wyglądało to raczej jakby władca odwiedzał swoją kolonię"27.

Sinolog Rudolf Fürst tak definiuje podziały w czeskim społeczeństwie dotyczące kwestii Tybetu i Chin: „Krytyczne opinie dotyczące współczesnego reżimu chińskiego, bliższe czeskiej prawicy i liberalnie nastawionym warstwom, dotyczą nieprzestrzegania praw człowieka i ucisku mniejszości narodowych. Na przeciwnym biegunie nasza lewica podziwia Chińską Republikę Ludową za osiągnięcia ekonomiczne, utrzymanie stabilizacji społecznej i reedukację zacofanego społeczeństwa Tybetu uciskanego przez system teokratyczny. Między tymi biegunami znajduje się bodaj najszersza grupa, preferująca interesy ekonomiczne Republiki Czeskiej, którym jakakolwiek krytyka Chin mogłaby zaszkodzić" ${ }^{28}$. Jednak podział ten nie pokrywa się jed-

26 Čekáme dodržení slibư, reagoval Peking na pročínské prohlášení českých ústavních činiteli̊, pravy.e15.cz/zahranicni/politika/cekame-dodrzeni-slibu-reagoval-peking-na-procinske-prohlaseni-ceskych-ustavnich-cinitelu-1324524.

27 Návštěva čínského prezidenta v ČR, http://www.kdu.cz/aktualne/archiv/2016/navsteva-cinskeho-prezidenta-v-cr.

28 R. Fürst, Politické vnímání..., s. 32 ; Miśkiewicz R., Industry 4.0 in Poland - selected aspects of its implementation, „Organizacja i Zarządzanie. 
noznacznie z podziałami politycznymi. Dotyczy to np. jednej z najważniejszych niegdyś partii politycznych w Republice, prawicowej ODS, stworzonej i przez lata kierowanej przez Václava Klausa, której politycy prezentują różne poglądy w kwestii Tybetu. W 2002 r. bliski współpracownik Klausa i wiceprzewodniczący partii Jan Zahradil mówił w kontekście Tybetu o „postdysydenckim kompleksie zbawicieli”, który uczynił z Czech „pariasa na chińskim rynku ${ }^{29}$, a w 2012 r. premier Republiki i przewodniczący ODS Petr Nečas uznał wspieranie dalajlamy za przeszkodę w rozwoju czeskiego eksportu ${ }^{30}$. Z kolei jego poprzednik na stanowisku premiera i przewodniczącego ODS, Mirek Topolánek, na konferencji prasowej przed wyjazdem na Igrzyska Olimpijskie w Pekinie w 2008 r. wystąpił z flagą Tybetu wpiętą w klapę marynarki, co skończyło się protestem chińskiego MSZ. Topolánek pojechał na olimpiadę na zaproszenie Czeskiego Komitetu Olimpijskiego, a w trakcie kilkudniowego pobytu nie odbył żadnego oficjalnego spotkania ${ }^{31}$. W 2014 r. wiceprzewodniczący ODS, Martin Kupka, skrytykował ministra Zaoralka za jego deklarację dotyczącą nieuznawania niepodległości Tybetu. Parlamentarzystów ODS nie brakuje w składzie Grupy Przyjaciół Tybetu. Obok partii TOP09, której jednym z liderów jest były minister spraw zagranicznych i bliski współpracownik prezydenta Havla, Karel Schwarzenberg, najbardziej jednoznaczne stanowisko w obronie Tybetu zajmuje Partia Zielonych. Jej program z 2017 r. nie odwołuje się bezpośrednio do kwestii Tybetu, konsekwentnie jednak odrzuca „dyplomację ekonomiczną", w której interesy gospodarcze są ważniejsze niż

Zeszyty Naukowe Politechniki Śląskiej” 2019, nr 136, s. 403..

29 Ibidem, s. 34.

30 Premiér Nečas považuje přehnané adorování za Pussy Riot i 'dalajlamismus' za prekážku exportu, http://www.rozhlas.cz/zpravy/domaciekonomika/_zprava/1108832.

31 M. Kořan et al., op.cit., s. 272-273. 
obrona praw człowieka ${ }^{32}$. W programie z 2010 r. w tym właśnie kontekście przywołano Tybet: „Nie zgadzamy się z tzw. dyplomacją gospodarczą, w której interesy handlowe Republiki Czeskiej powodują, że nasi dyplomaci nie mówią o wolności Tybetu, zabójstwach dziennikarzy w Moskwie czy więźniach na Kubie"33.

Republika Czeska, podobnie jak inne państwa Unii Europejskiej, nie wypracowała jednoznacznej, perspektywicznej strategii rozwoju współpracy politycznej i gospodarczej z Chinami w kontekście kwestii Tybetu i ochrony praw człowieka. Oficjalna ocena sytuacji w Chinach oraz miejsce Tybetu w kontaktach dwustronnych zależały zawsze od wewnętrznej sytuacji politycznej w Czechach i zmieniały się wraz z nią. Od początku przemian demokratycznych w Czechosłowacji i powstania samodzielnej Republiki Czeskiej sprawa Tybetu nie dotyczy wyłącznie stosunków z Chinami, lecz stanowi istotny element polityki wewnętrznej. Stosunek do kwestii Tybetu, mimo że dotyczy bardzo konkretnej sytuacji, stał się bowiem elementem rozdzielającym dwie różne wizje polityki, a dyskusja między reprezentującymi je obozami jest od ćwierćwiecza jednym z najważniejszych tematów czeskiego dyskursu politycznego i społecznego.

\section{Bibliografia}

Bílková V., Lidskoprávní rozmèr české zahraniční polityki, [w:] Česká zahraniční politika v roce 2014, red. M. Kořan, Praha 2015.

Czyżniewski M., Witkowska-Chrzczonowicz K., Prezyden-

32 Zelená politika jako odpovědnost za sdílený svět, http://www.zeleni. $\mathrm{cz} /$ dlouhodoby-program/.

33 Volební program Strany zelených, volby do Poslanecké sněmovny 2010, http://volic.cz/sz-volebni-program-2010.pdf. 
cja Republiki Czeskiej w Radzie Unii Europejskiej: studium prawno-politologiczne, Warszawa 2011.

Čekáme dodržení slibi̊, reagoval Peking na pročínské prohlášení českých ústavních činitelü, pravy.e15.cz/zahranicni/ politika/cekame-dodrzeni-slibu-reagoval-peking-na-procinske-prohlaseni-ceskych-ustavnich-cinitelu-1324524.

Filipiak Z., Zarys praktyki praw człowieka w Tybecie, „Studia Iuridica Torunensia" 2006.

Gorgol K., Kluczowe problemy polityczne w dialogu Unii Europejskiej z Chińską Republikg Ludowq u progu XXI wieku, „Forum Politologiczne” 2008, t. 8.

Fürst R., Česko-čínské vztahy po roce 1989, Praha 2010.

Fürst R., Podpora Tibetu, Tchaj-wanu a lidských práv v Činè: Evropská avantgarda neb český kýč?, [w:] Hledání českých zajmu: obchod, lidksá práva a mezinárodní rozvoj, red. Drulák, O. Horký, Praha 2010.

Fürst R., Politické vnímání Číny v Čechách, mezi věcností a nevěcností, orientalismem a okcidentalismem, „Mezinárodní vztahy" 2005, nr 3.

Klaus V., Před návštěvou v Číně, „Mladá fronta Dnes”, 8.4.2004, http://www.klaus.cz/clanky/1762

Koncepce zahraniční politiky České republiky, https://www.vlada.cz/cz/clenove-vlady/historie-minulych-vlad/!-koncepce-zahranicni-politiky-ceske-republiky-2156/\#44.

Kořan M. et al., Česká zahraniční politika v roce 2008, Praha 2009. Kořan M., Hrabálek M. (red.), Česká zahraniční politika: aktéri, struktura, proces, Brno 2007.

Kubiak Krzysztof, Tragedia Tybetu a strategii rozwojowa Chin, „Rocznik Bezpieczeństwa Międzynarodowego” 2008.

McCarthy R.E., Tears of the Lotus. Accounts of Tibetan Resistance to the Chinese Invasion, 1950-1962, Jefferson 1997. Michalak S., Problem Tybetu $i$ Tybetańczyków $w$ rezolucjach Parlamentu Europejskiego, „Studia Europejskie” 2008, nr 2. 
Miśkiewicz R., Industry 4.0 in Poland - selected aspects of its implementation, „Organizacja i Zarządzanie. Zeszyty Naukowe Politechniki Śląskiej” 2019, nr 136.

Návštěva čínského prezidenta v ČR, http://www.kdu.cz/aktualne/archiv/2016/navsteva-cinskeho-prezidenta-v-cr

Novoroční projev prezidenta ČSSR Václava Havla, 1.01.1990, http://vaclavhavel.cz/showtrans.php?cat=projevy\&val=327_ projevy.html\&typ=HTML.

Premiér Nečas považuje přehnané adorování za Pussy Riot i 'dalajlamismus' za překážku exportu, http://www.rozhlas. cz/zpravy/domaciekonomika/_zprava/1108832.

Prohlášení TOP 09 k návštěvě tibetského duchovního dalajlamy, http://www.top09.cz/co-delame/tiskove-zpravy/top09-ohnout-zada-je-jednoduche-21228.html.

Rozehnalová J., Zrcadlo orientalismu-obrazy Tibetu v českém prostředí, „Mezinárodní vztahy” 2005, nr 3.

Společné prohlášeni nejvyššich ústavních činitelů České republiky, https://www.hrad.cz/cs/pro-media/tiskove-zpravy/ aktualni-tiskove-zpravy/spolecne-prohlaseni-nejvyssich-ustavnich-cinitelu-ceske-republiky-12953.

Sporek T., Analiza stosunków handlowych pomiędzy Chińska Republiką Ludowa a Unia Europejska, „Studia Ekonomiczne. Zeszyty Naukowe Uniwersytetu Ekonomicznego w Katowicach" 2012.

Tiskové prohlášení ministerstev zahraničních věcí České republiky a Čínské lidové republiky, http://www.mzv.cz/jnp/cz/ udalosti_a_media/prohlaseni_a_stanoviska/x2014_04_29_ tiskove_prohlaseni_ministerstev.html.

Waisová Š., Tihá volby, Česká zahraniční polityka mezi principy a zajmy, Praha 2011.

Zbořil František, Československá a česká zahraniční politika: minulost a současnost, Praha 2010.

Žantovský M., Havel, Praha 2014. 


\begin{abstract}
Abstrakt
Temat Tybetu nie wpisuje się jedynie w stosunki Republiki Czeskiej z Chińską Republiką Ludową, lecz ma o wiele szerszą perspektywę: jest symbolem konfliktu między polityką zbudowaną na uniwersalnych ideach i wartościach a realizującą wyłącznie interesy gospodarcze i polityczne. W dużym stopniu jest to dziedzictwo ruchu dysydenckiego, który podkreślał wagę wartości i praw człowieka w polityce. Stosunek do kwestii Tybetu, mimo że dotyczy bardzo konkretnej sytuacji, stał się elementem rozdzielającym dwie różne wizje polityki. Dyskusja między reprezentującymi je obozami jest jednym z najważniejszych tematów czeskiego dyskursu politycznego i społecznego, a wiele osób działających w przestrzeni publicznej, zarówno polityków, jak i samorządowców, artystów czy naukowców, deklaruje swoje stanowisko w tej kwestii. Republika Czeska nie wypracowała jednoznacznej, perspektywicznej strategii rozwoju współpracy politycznej i gospodarczej z Chinami w kontekście kwestii Tybetu i ochrony praw człowieka. Oficjalna ocena sytuacji w Chinach oraz miejsce Tybetu w kontaktach dwustronnych zależały zawsze od wewnętrznej sytuacji politycznej w Czechach i zmieniały się wraz z nią.
\end{abstract}

Słowa kluczowe: Republika Czeska, Chiny, Tybet, prawa człowieka $\mathrm{w}$ polityce

\title{
Abstract
}

The Tibet issue is not only the part of the Czech-Chinese political and economical relations - it is a symbol of the conflict between the policy based on universal ideas and values and pursuing only economic and political interests. To a large extent, this is the heritage of the dissident movement, which emphasized the importance of values and human rights in politics. The attitude towards the Tibet issue, although it concerns a very specific situation, it has become an element separating two different visions of politics. The discussion between the camps representing them is one of the most important topics of Czech political and social discourse, and many people active in public space, both politicians and local government officials, artists or scientists, declare their position on this issue. The Czech Republic has not worked out a clear, forward-looking strategy for the development of political and economic cooperation with China in the context of the Tibet issue and the protection of human rights. The official assessment of the situation in China 
and the place of Tibet in bilateral contacts have always depended on the internal policy in the Czech Republic and have changed with the political situation.

Keywords: Czech Republic, China, Tibet, human rights in politics 


\section{Chińska decyzja administracyjna o ukaraniu - cechy językowe}

\section{Wstęp}

Budowa i leksyka decyzji administracyjnych jest przedmiotem badań w zakresie językoznawstwa specjalistycznego. W języku polskim dotychczas zajmowały się nimi m.in. prof. Maria Teresa Lizisowa i prof. Ewa Malinowska. Chińskie decyzje administracyjne nie zostały jeszcze opisane w ramach polskiego językoznawstwa sinologicznego. W niniejszym artykule opisane zostały struktura i leksyka, używane w chińskich decyzjach administracyjnych o ukaraniu. Porównano je również z budową polskiej decyzji administracyjnej, opisaną w pierwszej części tekstu.

Tego rodzaju dokumenty w języku polskim cechuje silna standaryzacja, szablonowość. Język urzędowy należy do sfery komunikacji oficjalnej (publicznej) i jest związana z działalnością urzędów, kancelarii, biur. Jedną ze stron komunikacji jest zawsze urząd/instytucja. Ważną cechą tej sfery jest jej formalny, zinstytucjonalizowany charakter. Relacje między podmiotami urzędowego dyskursu są hierarchiczne; dominuje podmiot instytucjonalny, który jest wyrazicielem woli władzy, działa w imieniu instytucji, państwa lub samorządu ${ }^{1}$. Działania

1 E. Malinowska, Styl-dyskurs - komunikacja urzędowa, [w:] Style wspótczesnej polszczyzny. Przewodnik po stylistyce polskiej, red. E. Malinowska, J. Nocoń, U. Żydek-Bednarczuk, Kraków 2013, s. 467. 
takich instytucji mają charakter konwencjonalny, są zanurzone w procedury prawnicze. Wypowiedzi urzędowe muszą zostać napisanie lub wygłoszenie przez określoną osobę (upoważnioną ustawowo) w określony proceduralnie sposób².

Na potrzeby poniższego artykułu przeanalizowano korpus dziesięciu chińskich decyzji administracyjnych o ukaraniu (xingzheng chufa jueding shu 行政处罚决定书), wydanych przez rozmaite instytucje, najczęściej organy administracji publicznej. Tekst zawiera wstępne uwagi dotyczące tego typu dokumentów, które mogą być pomocne w tłumaczeniu paralelnych dokumentów chińskich na język polski oraz polskich na język chiński. Nie wyczerpuje on tematu, stanowi raczej wstęp do dalszych badań i ma na celu zwrócenie uwagi na problem przekładu chińskich i polskich dokumentów administracyjnych oraz na potrzebę analizy i opisu chińskiego języka urzędowego. Cyfry w nawiasach okrągłych to numery analizowanych decyzji. Mają służyć zobrazowaniu ilości dokumentów, w których wystąpił dany zwrot oraz uporządkowaniu wiedzy o tym, które zwroty występowały w tych samych dokumentach. W nawiasach kwadratowych znajdują się odautorskie tłumaczenia chińskich zwrotów, służące zrozumieniu ich znaczenia. Nie są to formalne tłumaczenia pisane polskim językiem dokumentów administracyjnych.

\section{Definicja}

Decyzja oznacza rozstrzygnięcie sprawy. „Jest aktem administracyjnym zajmującym centralne miejsce wśród indywidualnych aktów stosowania prawa”3. Decyzja administracyjna to jedno-

2 Ibidem.

3 E. Malinowska, Język uzasadnień decyzji administracyjnych, [w:] W poszukiwaniu dobra wspólnego. Księga jubileuszowa Profesora Macieja Zielińskiego, red. A. Choduń, S. Czepita, Szczecin 2010, s. 853. 
stronny, instytucjonalny akt administracyjny; jest oświadczeniem woli organu administracji, które zyskuje moc prawną niezależnie od ustosunkowania się adresata do treści dokumentu ${ }^{4}$. Nadawca decyzji, którym jest aktualny decydent, działający w imieniu organu administracji, „rozstrzyga sprawę co do jej istoty w całości lub w części albo w inny sposób kończy sprawę w danej instancji” (art. 104 \$ 2 K.P.A.) $)^{5}$. W przypadku decyzji o ukaraniu, nadawcza instytucja stwierdza nastąpienie skutku prawnego zachowania adresata decyzji lub też nakłada na niego obowiązek ${ }^{6}$, najczęściej - obowiązek uiszczenia grzywny. Akt komunikacji odbywa się w ramach instytucjonalnych i adresat, który jest indywidualnie określony, powinien podporządkować się dyrektywom nadawcy.

\section{Struktura}

Niemal każdy gatunek urzędowy ma ściśle określony wzorzec tekstowy, zdeterminowany zasadami techniki prawodawczej ${ }^{7}$, instrukcjami kancelaryjnymi (zob. podręczniki z zakresu organizacji i techniki biurowej) lub Kodeksem postępowania administracyjnego ${ }^{8}$. „Gatunek to kulturowo i historycznie ukształtowany, ujęty w społeczne konwencje sposób językowego komunikowania się; wzorzec organizacji tekstu" ${ }^{\prime 9}$. Gatunki urzędowe charakteryzują się wysokim stopniem normatywności. Wynika ona

\section{Ibidem.}

5 Kodeks postępowania administracyjnego, art. 104. „Decyzje organu”, https://www.arslege.pl/decyzje-organu/k3/a738/ [dostęp: 20.02.2020].

6 E. Malinowska, Jezzyk uzasadnień..., op.cit., s. 853.

7 Zob. S. Wronkowska, M. Zieliński, Problemy i zasady redagowania tekstów prawnych, Warszawa 1993.

8 E. Malinowska, Wzorce wypowiedzi urzędowych a ich realizacja, [w:] Język, prawo, społeczeństwo, red. E. Malinowska, Opole 2004, s. 143.

9 S. Gajda, Gatunkowe wzorce wypowiedzi, [w:] Wspótczesny język polski, red. J. Bartmiński, Wrocław 1993, s. 245. 
z sytuacji komunikacyjnej, powtarzalności działań, pozwala powielać wyspecjalizowane sposoby realizacji tekstowych ${ }^{10}$. Językowym wykładnikiem konwencjonalizacji są formuły, zamieszczane na początku, wewnątrz i na końcu tekstu. Skodyfikowane są nie tylko gatunki prawne ${ }^{11}$. O strukturze dokumentów decydują m.in. miejsce komunikacji, typ przekazu, role społeczne rozmówców i kategoria odbiorcy. Ukształtowanie stylistyczne zależy od kompetencji językowo-stylistycznej nadawcy komunikatu ${ }^{12}$.

Decyzja to gatunek sformalizowany, przejrzysty kompozycyjnie (jej wzór ogólny wskazują przepisy K.P.A.). Pismo jest rozplanowane przestrzennie. Widoczną cechą gatunków prawnych jest podział tekstu na artykuły lub paragrafy. Nadawca używa środków graficzno-typograficznych w celu przykucia uwagi do poszczególnych fragmentów i zwiększenia zrozumiałości treści. Teksty dokumentów urzędowych są silnie ustandaryzowane i szablonowe, co wiąże się z powtarzalnością sytuacji, do których się odnoszą oraz z warunkiem ich fortunności (inaczej są pozbawione mocy sprawczej). Styl dokumentów urzędowy wyróżnia się dyrektownością, bezosobowością i precyzją ${ }^{13}$. Cechy te występują z różnym natężeniem we wszystkich wariantach stylu urzędowego. Językowym wykładnikiem konwencjonalizacji są stałe formuły.

Struktura rozstrzygnięć z danej sfery „musi zawierać wszystkie elementy, które łącząc się w logicznie zespoloną całość nadają czynności organu walor decyzji administracyjnej. Elementy te wyznacza art. $107 \$ 1$ K.P.A."14. Według niego na prawidłową formalnie decyzję składają się:

10 E. Malinowska, Wzorce wypowiedzi..., op.cit., s. 144.

11 Eadem, Styl-dyskurs - komunikacja urzędowa..., op.cit., s. 474.

12 Eadem, Wzorce wypowiedzi..., op.cit., s. 144.

13 Eadem, Styl-dyskurs - komunikacja urzędowa..., op.cit., s. 470.

14 P. Dańczak, Decyzja administracyjna w indywidualnych sprawach studentów i doktorantów, Warszawa 2015, s. 97. 
- oznaczenie organu administracji;

- data wydania;

- oznaczenie strony lub stron;

- powołanie podstawy prawnej;

- rozstrzygnięcie;

- uzasadnienie faktyczne i prawne;

- pouczenie o przysługujących środkach zaskarżenia;

- podpis z podaniem imienia i nazwiska oraz stanowiska służbowego osoby upoważnionej do wydania decyzji.

Na mocy $\$ 2$, w wypadku stanowienia o takiej ewentualności przepisów szczególnych, decyzja może posiadać także inne składniki, jak: warunek, termin czy zlecenie ${ }^{15}$.

Tekst decyzji polskiej składa się z trzech wydzielonych graficznie segmentów: osnowy, uzasadnienia i pouczenia. Osnowa (sentencja) zawiera meritum sprawy: rozstrzygnięcie i wskazuje jego podstawę prawną. Najczęściej ma formę jednego, rozbudowanego wypowiedzenia. Pouczenie to najkrótsza część decyzji, która również podlega procesowi standaryzacji, jako jeden ze sposobów przestrzegania przez nadawcę zasady udzielania informacji prawnej odbiorcy ${ }^{16}$, wskazuje też na możliwość ponownego rozpatrzenia sprawy przez sąd lub inny organ administracji. Uzasadnienie to najobszerniejsza część decyzji administracyjnej. W tej części nie ma ustalonego wzoru, toteż najpełniej ujawnia się w niej kompetencja językowo-stylistyczna nadawcy. Czasami, gdy sprawy się powtarzają, urzędnicy opracowują wzór decyzji zawierający szablon uzasadnienia ${ }^{17}$.

Uzasadnienie ma na celu wskazanie wszystkich okoliczności sprawy, uwzględnionych w postępowaniu wyjaśniającym i przyjętych jako stan faktyczny przez decydenta. W uzasad-

\footnotetext{
15 Ibidem.

16 E. Malinowska, Język uzasadnień..., op.cit., s. 855.

17 Ibidem, s. 856.
} 
nieniu wykazuje się, że rozstrzygnięcie sprawy zawarte w osnowie jest logicznie poprawnym wynikiem procesu myślowego, w którym do ustalenia konkretnej sprawy zastosowano normę prawną $^{18}$. Zawiera wywód wskazujący środki i rozumowanie, na podstawie których uznano okoliczność za udowodnioną. W uzasadnieniu występuje zatem dużo słownictwa pełniącego funkcję faktograficzną ${ }^{19}$. Czasami ich nagromadzenie utrudnia odbiór dokumentu. Kompozycja uzasadnienia jest zwykle trójczłonowa. Pierwsze zdanie pełni funkcję wstępu, przedstawia sprawę, nawiązując do osnowy decyzji, kolejny segment (zwykle 2-3-zdaniowy) przedstawia faktyczne i prawne fakty uzasadniające rozstrzygnięcie. Trzecia część, jednozdaniowa, nawiązuje bezpośrednio do sentencji i podsumowuje uzasadnienie $^{20}$.

Chińska decyzja administracyjna o ukaraniu składa się zwykle z następujących części:

- nazwa organu wydającego decyzję;

- numer dokumentu administracyjnego;

- dane popełniającego wykroczenie (wyróżnione);

- opis popełnionego wykroczenia i podanie naruszonej reguły/przepisu prawnego;

- lista dowodów wykroczenia

- opis kary: upomnienie oraz kara finansowa, czasami inna;

- konsekwencje związane z niezastosowaniem się do wymierzonej kary;

- możliwości odwołania i skargi;

- pieczęć, data;

- podpis odbiorcy potwierdzający odbiór dokumentu.

\footnotetext{
18 Ibidem, s. 857.

19 Ibidem.

20 Ibidem, s. 859.
} 


\section{Cechy językowe}

Leksyka decyzji jest zdeterminowana przez jej tematykę; zróżnicowanie słownictwa jest związane z tym, że decyzje dotyczą różnych dziedzin regulowanej przez prawo praktyki społecznej.

W decyzjach używane jest specyficzne prawne słownictwo o wyższej, niż w tekstach pozaprawnych, frekwencji, np: strona, organ, artykuł, paragraf, ustawa, osoba prawna, osoba fizyczna itp. $^{21}$

Czynność nadawcy, który wykorzystując pragmatyczną funkcję rozstrzygnięcia informuje o tym, co postanawia jest wyrażana za pomocą czasowników performatywnych ${ }^{22}$. Intencja ta jest wyrażana albo poprzez czasowniki performatywne w 1 . osobie liczby pojedynczej czasu teraźniejszego w trybie oznajmującym: ustalam, orzekam, nakładam, zatwierdzam, utrzymuję, zawieszam postępowanie, stwierdzam - albo bezosobowo z morfemem się: zmienia się, umarza się, nakazuje się, utrzymuje się w mocy, orzeka się, uchyla się ${ }^{23}$. W polskiej decyzji administracyjnej wybór formy osobowej lub bezosobowej jest indywidualną decyzją nadawcy. W chińskich dokumentach paralelnych sytuacja wygląda podobnie. Są używane zarówno rzeczowniki pospolite, jak również zaimki.

Bazą leksykalną dla decyzji polskich i chińskich jest słownictwo języka ogólnego ${ }^{24}$. Ponadto stosowane jest słownictwo dyrektywne, zdefiniowane w tekstach prawnych ${ }^{25}$ : nakaz, za-

21 Ibidem, s. 854.

22 Ibidem.

23 Ibidem, s. 855.

24 M. Zieliński, Wykładnia prawa: zasady, reguty, wskazówki, Warszawa 2002, s. 162 .

25 A. Choduń, Stownictwo tekstów aktów prawnych $w$ zasobie leksykalnym współczesnej polszczyzny, Warszawa 2007. 
kaz, dozwolenie, obowiązek, wyrażane w różnych formach. Poprzez kontekst likwiduje się wieloznaczność czasowników wyrażających treść nakazu².

Standardowe formuły językowe, używane w chińskiej decyzji administracyjnej o ukaraniu, zostały w niniejszym artykule podzielone na określające nadawcę i odbiorcę, opisujące wykroczenie i jego dowody, powołanie podstawy prawnej, opisujące konsekwencje grożące adresatowi w przypadku niezastosowania się do wytycznych i możliwości odwołania się od określonej decyzji.

Do formuł, których używa się na określenie nadawcy komunikatu, należą:

$$
\begin{aligned}
\text { - wo ting 我 厅, ben jiguan 本机关 (2) (4) } \\
\quad \text { [(Nasz) sąd; (nasza) struktura]; } \\
\text { - wo zhongxin 我中心 (3) [Nasze centrum]; } \\
\text { - wo ju 我局 (6) (7) [Nasze biuro]. }
\end{aligned}
$$

W niektórych analizowanych dokumentach (9) nie znalazły się określenia odnoszące się do nadawcy.

Odbiorcę określa się w decyzjach o ukaraniu następującymi terminami:

- Weifa xingwei ren; 违法行为人 (1) [popełniający wykroczenie].

- Ni gongsi 你公司 (1) [Państwa firma].

- Faren 法人 (1) [osoba prawna].

- Ni danwei 你单位 (2) (3) (4) (7) (8) (9) [Państwa jednostka].

- Do określenia osoby prywatnej używany bywa najczęściej zaimek $N i$ 你 [Ty] (5) (10); warto wspomnieć, że w dokumentach prawnych używany jest zaimek bardziej honoryfikatywny Nin 您 (Pan/Pani).

- W jednej z badanych decyzji pojawiło się także okres. 473.

26 E. Malinowska, Styl-dyskurs - komunikacja urzędowa..., op.cit., 
ślenie opisujące wykroczenie - Bu niao ren 捕鸟人 (6) (osoba, która [nielegalnie] łapała ptaki).

- W celu wprowadzenia danych ukaranej osoby pisze się na przykład Bei chufa ren xingming 被处罚人姓名 [nazwisko i imię ukaranego].

Informacja o wykryciu wykroczenia jest zwykle przekazywana formułą „Odkryliśmy, że Państwa firma dopuściła się wykroczenia przeciwko [następującej ustawie/regulacji]:...." W języku chińskim sformułowania te brzmią następująco:

- Xian chaming ni gongsi weifanle... de guiding. 现查明 你公司违反了。。的规定。(1) (3) [Odkryliśmy, że Państwa firma dopuściła się wykroczenia przeciwko ustawie...].

- Ben jiguan renwei ni danwei de shangshu xingwei weifanle... de guiding. 本机关认为你单位的上述行为违反了。 。的规定。(2) [Nasza struktura uważa, że Państwa jednostka popełniła wykroczenie przeciwko zasadzie...].

- (Yishang) xingwei weifanle... de guiding. (以上)行为违反 了。。的规定。(4) (5) (7) (8) (10) [Wyżej opisane zachowanie jest wykroczeniem przeciwko ustawie...].

W jednej z analizowanych decyzji podano, że pracownik zmarł w wypadku przy pracy, nie przywołano natomiast żadnego przepisu. Konsekwencją było zawieszenie działania fabryki na określony czas (9).

Po określeniu wykroczenia, w decyzjach podane zostają dowody na jego popełnienie. Do ich wprowadzenia używa się poniższych sformułowań:

- Yishang shishi you ... de zhengju zhengshi. 以上事实有。 。。的证据证实。(1) [Powyższe wykroczenie potwierdzają następujące dowody].

- Yishang shishi you ... de zhengju wei ping. 以上事实, 有。。。证据为凭。(2) [Na potwierdzenie powyższego wykroczenia istnieją następujące dowody]. 
- Shangshu xingwei ji shishi you:... deng zhengju wei zheng 上述行为及事实有：。。等证据为证 (6) [Wyżej opisane zachowanie i wykroczenie zostało udowodnione następującymi dowodami.... itd.].

W części analizowanych decyzji nie występują zwroty, mające na celu powołanie się na istniejące dowody wykroczenia (w decyzjach nr 3, 4, 5, 7, 10).

W następnej kolejności nadawca decyzji informuje adresata komunikatu o konsekwencjach, wynikłych z określonej i podanej w tekście podstawy prawnej. Używa się do tego następujących zwrotów:

- Genju... xian jueding dui zeling jinzhi shigong bing chufakuan renminbi... de chufa. 根据。。。现决定对。。。 责令禁止施工并处罚款人民币。。。的处罚。(1) [ $\mathrm{Na}$ podstawie... żąda się zaprzestania kontynuacji prac i decyduje o nałożeniu kary w wysokości... RMB].

- Genju... de guiding, zeling ni danwei gaizheng shangshu weifa xingzheng, bing dui ni danwei chu yi ruxia xingzheng chufa... 根据。。。的规定, 责令你单位改正上 述违法行为, 并对你单位处一如下行政处罚。。。(2) (3) (4) (5) [Na podstawie... przepisów, żąda się zaprzestania przez Twoją Jednostkę nielegalnych zachowań i nakłada się na Twoją Jednostkę następującą karę...].

- Genju... de guiding, ben jiguan jueding dui ni chu yixia xingzheng chufa 依据。。。的规定, 本机关决定对你 出以下行政处罚 (6) [Na podstawie... przepisów, nasza struktura decyduje o nałożeniu na Ciebie poniższej kary administracyjnej].

W trzech powyższych przypadkach cyfry zostały napisane znakami tradycyjnymi, żeby udaremnić próby zmiany kwoty kary na niższą.

- Xian yaoqiu ni danwei... jiang 100000.00 yuan fakuan jiaozhi daishou yinhang 现要求你单位。。。将 
100000.00 元罚款交至代收银行 (7) [Wymaga się, by Twoja jednostka zapłaciła 100000.00 juanów kary bankowi przedstawicielskiemu].

W dwóch dokumentach (8) (10) kwoty wysokości kary zapisano cyframi arabskimi.

W decyzji (10) pojawiło się wyliczenie za pomocą wzoru matematycznego całej kwoty kary.

W decyzji (9) napisano, że firma zostaje w konsekwencji zamknięta na 30 dni (9).

Następnie adresat decyzji jest informowany o tym, co wydarzy się w przypadku jego niezastosowania się do określonych powyżej wymagań. Konsekwencje, które mogą mieć miejsce, to na przykład:

„Wysokość kary będzie rosła każdego dnia o 3\% podstawowej sumy" (2) (5) (7) (8) (10):

- Yuqi bu jiaona chukuan de, mei ri an chufa shu'e de bai fen zhi san jia chufakuan, jia chufakuan de shu'e bu chaoguo fakuan benshu. 预期不缴纳出款的, 每日按出发 数额的百分之三加处罚款, 加处罚款的数额不超过罚 款本数。(1) [W przypadku nieuiszczenia kary, każdego dnia do wysokości opłaty będą doliczane $3 \%$ sumy podstawowej, jednak całość doliczonej opłaty nie może przekroczyć tej sumy].

„Spłata będzie egzekwowana na drodze sądowej”:

- Wo zhongxin jiang yifa shenqing Renmin Fayuan qiangzhi zhixing 我中心将依法申请人民法院强制执行 (3) (10) [Nasze centrum będzie się zgodnie z prawem odwoływało do Sądu Ludowego o wymuszenie wykonania postanowień decyzji].

- Ben jiguan youquan shenqing Renmin Fayuan qiangzhi zhixing 本机关有权申请人民法院强制执行 (8) [Nasza struktura ma prawo odwołać się do Sądu Ludowego w celu wymuszenia wykonania postanowień decyzji]. 
- Yuqi bu lüxing xingzheng chufa jueding de, ben jiguan jiang yifa caiqu xialie cuoshi: shenqing Renmin Fayuan qiangzhi zhixing. Zhixing feiyong you ni chengdan. 预 期不履行行政处罚决定的，本机关将依法采取下列措 施: 申请人民法院强制执行。执行费用由你承担。(4) (5) (6) [W przypadku nie wypełnienia postanowień niniejszej decyzji administracyjnej o ukaraniu, nadawca odwoła się do Sądu Ludowego w celu wymuszenia wykonania postanowień decyzji. Ty poniesiesz koszty postępowania].

Uzasadnienie może być pisane dla dwóch odbiorców: strony (która najczęściej nie zna przepisów prawa i zasad postępowania) i organu odwoławczego, który nie zna strony ani stanu faktycznego ${ }^{27}$. Dla strony uzasadnienie musi zatem być pisane prostym, zrozumiałym językiem. Dla organu odwoławczego natomiast nadawca powinien bardzo dokładnie opisać sprawę, motywy decydujące o jej rozstrzygnięciu i przebieg swojego rozumowania. Wszystko to ma na celu jak najbardziej prawomocne i sprawiedliwe rozwiązanie sprawy.

W decyzjach innego, niż karne, rodzaju, czasami uzasadnienie nie występuje w ogóle. „Można odstąpić od uzasadnienia decyzji ze względu na interes bezpieczeństwa państwa lub porządek publiczny, a także, gdy decyzja uwzględnia w całości żądanie strony" (art. 107 \$ 4 K.P.A.). Wtedy w części uzasadnienia umieszczana jest formuła „Na podstawie art. $107 \$ 4$ K.P.A. odstępuje się od uzasadnienia decyzji, gdyż uwzględnia ona w całości żądanie strony". Takie zjawisko może mieć miejsce jedynie w decyzjach pierwszej instancji ${ }^{28}$. Nie dotyczy to jednak decyzji o ukaraniu, w których musi zostać podana przyczyna nałożenia sankcji.

\footnotetext{
27 Eadem, Język uzasadnień..., op.cit., s. 864.

28 P. Dańczak, Decyzja administracyjna..., op.cit., s. 108.
} 
W chińskiej decyzji administracyjnej o ukaraniu - podobnie jak w polskiej - na zakończenie umieszcza się także formułę, która ma na celu uświadomienie adresatowi jego prawo do odwołania się od decyzji nadrzędnego organu. Jest to zdanie omijane często w decyzjach zezwalających. W karnych jednak jest ono bardzo istotne. Nie zauważono dużej różnorodności budowy tego typu zdań. W 9 z 10 analizowanych dokumentów wyglądało ono następująco:

- Keyi shenqing xingzheng fuyi, tiqi xingzheng shangsu 可 以申请行政复议, 提起行政上诉 (1) (2) (3) (4) (5) (6) (7) (8) (9) (10) [Można odwoływać się, składać skargę administracyjną].

Do tego zdania dopisywana bywa dalsza część, informująca o tym, że mimo wszystko w trakcie odwoływania się odbiorca decyzji winien jest wykonywać lub uiszczać karę, dopóki wyższa instancja nie zdecyduje inaczej:

- Dan bu de tingzhi zhixing ben chufa jueding 但不得停止 执行本处罚决定 (5) [Nie należy zaprzestać wykonywania postanowień tej decyzji o ukaraniu].

Wreszcie, zwykle pod dokumentem, znajduje się okrągła pieczęć instytucji (często z czerwoną gwiazdą w centrum, otoczoną nazwą jednostki administracyjnej) i data wystawienia dokumentu, czasami także podpis decydenta. Zdarza się również podpis adresata, potwierdzający odebranie decyzji.

\section{Wnioski}

Chińską decyzję administracyjną o ukaraniu jako gatunek cechuje:

- brak wyróżnień graficznych - poszczególne części dokumentu nie są wyodrębnione.

- Różny stopień standaryzacji. 
- Określone słownictwo - szczególnie rzuca się w oczy określanie adresata nieformalnym zaimkiem $n i$ 你 [Ty]. Poza tym leksyka jest zbliżona do chińskiego języka prawnego.

- W decyzjach prawie zawsze przywoływana jest podstawa prawna.

- Często przytaczane są dowody popełnionego wykroczenia.

- Nadawca decyzji uzasadnia nałożenie na odbiorcę sankcji karnej.

- Zawsze również wymieniony jest odbiorca decyzji, w przeciwieństwie do nadawcy, którego dane nie zawsze pojawiają się w treści dokumentu - pojawiają się jednak w nagłówku i na pieczęci.

- W niektórych decyzjach pojawia się również potwierdzenie odbioru dokumentu przez adresata.

Chińska decyzja administracyjna o ukaraniu jest szczególnie interesująca, ponieważ zawiera w sobie wiele danych: od danych o nadawcy i odbiorcy, poprzez informacje o szczegółach wykroczenia i dowodach, a także podstawy prawne do ukarania - aż po wiadomość o nałożonej karze. Kara musi być uzasadniona, choć najczęściej wynika to po prostu z prawa. W drastycznym wypadku, jakim była śmierć jednego z pracowników w miejscu pracy, decydent nie powoływał się na podstawę prawną, zarządził natomiast zamknięcie fabryki na określony czas. W innej analizowanej decyzji na lekarza zostały nałożone dwie kary, zgodne z prawem Chińskiej Republiki Ludowej - jedna za „,nieuzasadnione sprawdzenie płci nienarodzonego dziecka", druga za przerwanie ciąży.

Artykuł ten nie wyczerpuje tematu. Stanowi jedynie wstępne rozpoznanie i przyczynek do dalszych badań chińskiego języka administracyjnego. Ze względu na dynamicznie rozwijające się stosunki gospodarcze i relacje polityczne Polski 
z Chińską Republiką Ludową, warto jest badać język chiński w każdym jego aspekcie, ponieważ tłumacze tekstów urzędowych, prawnych i specjalistycznych mają wciąż bardzo niewiele materiałów edukacyjnych i pomocy naukowych. Przydatne mogłoby okazać się tworzenie słowników lub też podręczników, zawierających teksty paralelne i wskazówki dotyczące ich przekładu na języki obu tych państw. Warto przeanalizować również język urzędowy różnych części Chin i innych obszarów, których mieszkańcy posługują się językiem chińskim, jak Hongkong, Tajwan, Singapur i tak dalej. Badania powinny być dalej prowadzone w celu poprawy komunikacji między obywatelami a instytucjami, która stanowi naglącą i rosnącą potrzebę naszych czasów.

\section{Bibliografia}

Choduń A., Słownictwo tekstów aktów prawnych $w$ zasobie leksykalnym wspótczesnej polszczyzny, Warszawa 2007.

Dańczak P., Decyzja administracyjna $w$ indywidualnych sprawach studentów i doktorantów, Warszawa 2015.

Gajda S., Gatunkowe wzorce wypowiedzi, [w:] Współczesny język polski, red. J. Bartmiński, Wrocław 1993.

Lizisowa M., Retoryczne aspekty dyskursu prawnego, [w:] W poszukiwaniu dobra wspólnego. Ksiega jubileuszowa Profesora Macieja Zielińskiego, red. A. Choduń, S. Czepita, Szczecin 2010.

Malinowska E., Nocoń J., Żydek-Bednarczuk U., Style wspótczesnej polszczyzny: przewodnik po stylistyce polskiej, Kraków 2013.

Malinowska E., Język uzasadnień decyzji administracyjnych, [w:] W poszukiwaniu dobra wspólnego. Księga jubileuszowa Profesora Macieja Zielińskiego, red. A. Choduń, S. Czepita, Szczecin 2010. 
Malinowska E., Struktura i pragmatyka decyzji administraсуjnej, „Zeszyty Naukowe Uniwersytetu Opolskiego” 1996, nr 16.

Malinowska E., Styl - dyskurs - komunikacja urzędowa, [w:] Style wspótczesnej polszczyzny. Przewodnik po stylistyce polskiej, red. E. Malinowska, J. Nocoń, U. Żydek-Bednarczuk, Kraków 2013.

Malinowska E., Wzorce wypowiedzi urzędowych a ich realizacja, [w:] Język, prawo, społeczeństwo, red. E. Malinowska, Opole 2004.

Wojtak M., Gatunki urzędowe na tle innych typów piśmiennictwa użytkowego - zarys problematyki, [w:] Jezyk, prawo, spoteczeństwo, red. E. Malinowska, Opole 2004.

Wronkowska S., Zieliński M., Problemy i zasady redagowania tekstów prawnych, Warszawa 1993.

Zieliński M., Języki prawne i prawnicze, [w:] Polszczyzna 2000. Orędzie o stanie języka na przełomie tysiacleci, red. W. Pisarek, Kraków 1999.

Zieliński M., Wykładnia prawa: zasady, reguty, wskazówki, Warszawa 2002.

\section{Abstrakt}

Artykuł został poświęcony strukturze i leksyce chińskiej decyzji administracyjnej o ukaraniu. W pierwszej części tekstu powołano się na wyniki badań polskich językoznawców, dotyczących języka i budowy decyzji administracyjnej oraz struktury gatunków urzędowych. W drugiej części opisano język i słownictwo, używane w chińskich decyzjach administracyjnych o ukaraniu i podano przykłady, zaczerpnięte z przebadanych dziesięciu dokumentów. Język dokumentów administracyjnych cechuje silna standaryzacja i szablonowość, jednak mniejszy stopień formalności, niż język prawny. Badanie struktury i języka paralelnych dokumentów administracyjnych jest ważne i potrzebne ze względu na rozwój relacji polsko-chińskich i potrzebę tłumaczenia dokumentów. 
Słowa kluczowe: Chiny, decyzja, administracja, język urzędowy, dokument, teksty paralelne

\begin{abstract}
The article is devoted to the structure and lexis of the Chinese administrative punishment decision. The first part of the text refers to the results of Polish linguists research, regarding the language and structure of administrative decisions as well as the structure of official genres. The second part describes the language and vocabulary used in Chinese administrative punishment decisions and shows examples from the corpus of 10 analysed documents. The important feature of the language of administrative documents is strong standardization, but also a lower degree of formality than in the legal language. The study of the structure and language of parallel administrative documents is important and necessary due to the development of Polish-Chinese relations and the need of translating documents.
\end{abstract}

Keywords: China, decision, administration, official language, document, parallel texts 


\section{Iwona Grodź}

Wyższa Szkoła Umiejętności Społecznych

im. Prof. Michała Iwaszkiewicza w Poznaniu

ORCID ID: https://orcid.org/0000-0003-0151-6909

\section{Zhang Yimou. Między prawdą a iluzją...}

„Pytasz, czemu w nefrytowych przebywałem górach? Uśmiecham się, milczę - umysł mój jest nieobecny. Jak kwiat brzoskwini wodą unoszony oddala się bez celu, W innym przebywam świecie, a nie między ludźmi" Li Sai, Pytania i odpowiedzi w górach

„W pałacu swoim, w wieczornej ciszy i kwiatów stu aromacie Cesarzowa zasłonę z perełek chce podnieść, wiosenną melancholią

[ogarnięta I lutnię trzymając, w głębi, drzewami przysłonięty, Blask księżyca widzi - ogromnego - wschodzącego"

Li Sai, Wiosenna melancholia w pałacu cesarzowej ${ }^{1}$

Znawcy kultur azjatyckich twierdzą, że miejscem, w którym dochodzi do spotkania Wschodu z Zachodem jest poziom ontologiczny świata przedstawionego w dziełach sztuki. Chodzi o relację między realnością i iluzją. Jedna i druga kategoria odsyła do dwóch poziomów myślenia o sztuce, a więc i o filmie. $Z$ jednej strony ważny jest namysł nad samą istotą dzieła, a więc zjawiskiem reprezentacji, które odsyła do pojęcia mimesis (przestrzeń zewnątrztekstowa). Z drugiej, o podejmowaną tematykę i stosunek autora do zaproponowanego materiału zjawisko kreacji i imitacji (przestrzeń wewnątrztekstowa). Oba sposoby podejścia do opisu fascynacji Zachodu Wschodem, które daje się zaobserwować już w XIX w., w dobie roman-

1 Li Sai (701-762), Dzwoneczki nefrytowe w księżycowej poświacie. Wybór wierszy chińskich, Warszawa 2003, s. 48, 58, 118. 
tyzmu ${ }^{2}$, sugerują konieczność zmierzenia się z zagadnieniem natury filozoficzno-psychologicznej i historycznej.

Dotychczasowy charakter fascynacji Zachodu Wschodem i Wschodu Zachodem w sztuce filmowej był bardzo powierzchow$n y^{3}$. Kinematografię zachodnią zawsze fascynowała odmienność, która pozwala wypełnić czas pustki i znudzenia własną kulturą. Jest to, jak to zwykle bywa, zainteresowanie czasowe, zwykle bardzo efemeryczne, typowe dla kultury masowej, oparte na zasadzie „kulturowego konsumpcjonizmu”. W przypadku Polski związane dodatkowo z „amerykanizacją", a więc filtrem pośrednictwa Ameryki - kraju, który ma największy wpływ na Europę. Taki sposób podejścia do tego tematu możemy zauważyć u niemal wszystkich twórców zachodnich, nawiązujących do tej tematyki w swoich filmach: Peter Greenawy (m.in. The Pillow Book, 1996), Jim Jarmusch (Mistery Train, 1989), Quentin Tarantino (Kill Bill, 2003 i 2004), Sophia Coppola (Między stowami, 2003), Bernardo Bertolucci (Ostatni cesarz, 1987) i jeszcze wielu innych.

W przypadku Wschodu istota tkwi przede wszystkim w próbie wyzwolenia się, przekraczania symbolicznego muru izolacjonizmu. A więc z jednej strony, konieczności opisywania świata, którego naprawdę nie można opisać. Z drugiej, o pęd do sukcesu. Wystarczy przywołać takich twórców, jak Ang Lee ${ }^{4}$, Wong Kair-Wai ${ }^{5}$,

2 Z tym wiekiem można wiązać dwa pojęcia: „egzotyzm” i „orientalizm” ważne dla badań kulturowych, które są punktem wyjścia dla rozważań nad fascynacją filmami Zhanga Yimou w Polsce (zob. J. Sławiński (red.), Stownik terminów literackich, Wrocław 2000, s. 121, 361). W związku z tym zagadnieniem warto sięgnąć też do następujących tekstów: E. Kuźma, Semiologia egzotyki, [w:] Miejsca wspólne, red. E. Balcerzana, S. Wysłouch, Warszawa 1985; E.W. Said, Orientalizm, tłum. W. Kalinowski, Warszawa 1991.

3 Zob. P. Kletowski, Kino Dalekiego Wschodu, Warszawa 2008.

4 Ang Lee (ur. 1954 w Tajwanie). Twórca m.in. takich filmów, jak: Rozważna i romantyczna (1995), Burza lodowa (1997), Przyczajony tygrys, ukryty smok (2000), Hulk (2003), Tajemnica Brokeback Mountain (2005), Ostrożnie pożądanie (2007), Zdobyć Woodstock (2009) itp.

5 Wong Kar-Wai (ur. 1958 w Chinach, potem przeniósł się do Hongkongu). Twórca m.in. takich filmów, jak: Chunking Express (1994), Upadte 
a ostatnio Zhanga Yimou, którzy realizujące filmy dla masowego widza wielokrotnie rezygnowali z wiarygodności. Propozycje tych twórców z czasem były coraz bardziej amerykańskie (nie tyle europejskie). Sukces na Zachodzie wielokrotnie oznaczał krytykę we własnym kraju.

Nadzieję na pogłębienie wiedzy i poszerzenie świadomości różnic między tymi dwoma obszarami daje zamysł nad różnicami i relacjami między sposobami widzenia, między interpretacją pojęć: realność i iluzja. Jest to poziom, na którym dochodzi do autentycznego spotkania Wschodu z Zachodem. Chodzi o związek między zachodnim widzeniem świata przez pryzmat religii lub kosmologii, a wschodnim spojrzeniem, u podstaw którego leży nauka.

Rysynek 1. Shitao (1642-1707)

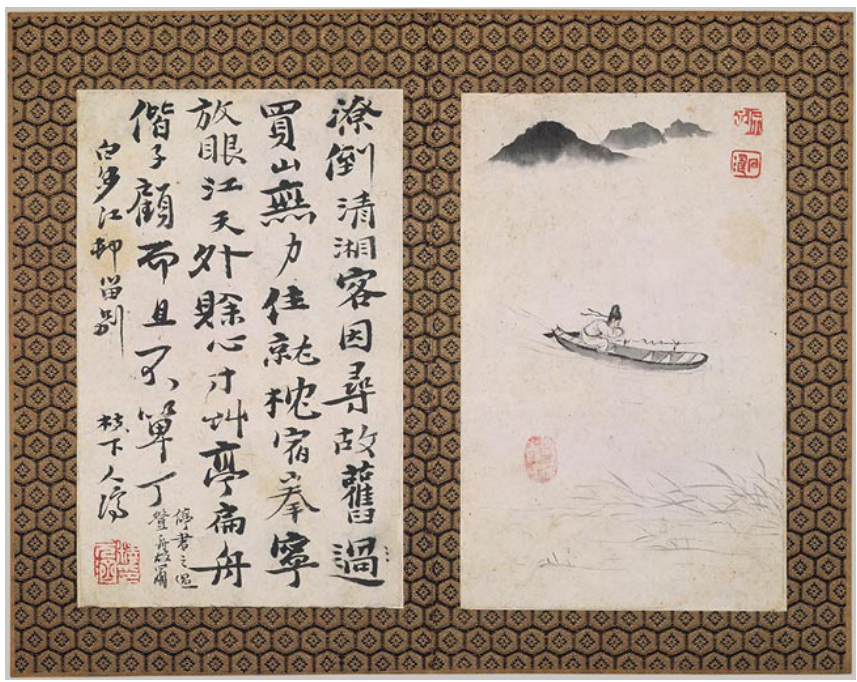

anioty (1995), Happy Together (1997), Spragnieni mitości (2000), 2064 (2004), Jagodowa miłość (2007) itp. Zob. też książki E. Mazierska, Uwięzieni w teraźniejszości i inne postmodernistyczne stany, Warszawa 1996; J. Aleksandrowicz, Pomiędzy obrazem a wskazówkami zegara: o estetyce nietrwatości w filmach Wong Kar-Waia, Kraków 2008. 


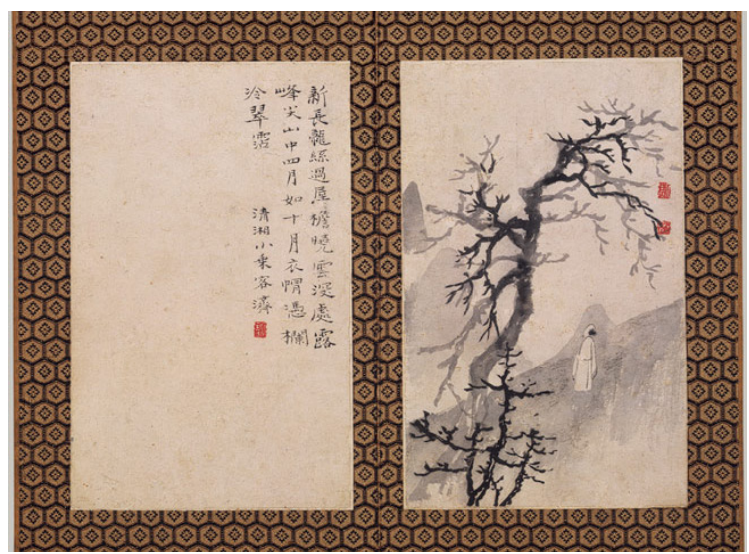

Źródło: domena publiczna.

Uzmysłowienie sobie odmienności wschodniego widzenia pozwala spojrzeć na film azjatycki z nowej perspektywy. Jeżeli uznamy, że rzeczywistość jest iluzją i to właśnie ona jest obdarzana cechą fikcyjności dzieła sztuki, to ono samo będzie jedynie kopią czegoś czego nie ma, a więc kopią kopii - symulakrem $^{6}$. To pojęcie zbliża obie cywilizacje. Wschodni sposób percepcji związany z filozofią zostaje włączony w nowy obszar widzialności. Zachodni, związany przede wszystkim z kulturą masową, często bezrefleksyjne wchłania to, co nowe. Nadzieją pozostają lektura w trybie symbolicznym wg Umberto $\mathrm{Eco}^{7}$, analizy semiotyczne Rolanda Barthesa ${ }^{8}$, i przede wszystkim rozwijające się współcześnie badania kulturowe ${ }^{9}$.

6 Zob. J. Baudrillard, Symulacje i symulakry, tłum. S. Królak, Warszawa 2005.

7 U. Eco, Tryb symboliczny, [w:] Teorie literatury XX wieku. Antologia, red. M. Markowski, A. Burzyńska, Kraków 2006; idem, Nieobecna struktura, tłum. A. Weinsberg, P. Bravo, Warszawa 1996 itp.

8 Zob. m.in. R. Barthes, Imperium znaków, tłum. A. Dziadek, Warszawa 2000.

9 Zob. m.in. M. Markowski, A. Burzyńska (red.), Teorie literatury XX wieku..., op.cit., s. 521-540. 
Brak świadomości teoretycznej prowadzi do uzasadnionych obaw filmoznawców, którzy wskazują niezbywalny fakt, widz polski, podobnie jak widz masowy, może w ogóle nie zadać sobie trudu uświadomienia w jaki sposób i na jakich zasadach filmy z tego kręgu kulturowego funkcjonują w naszej kinematografii. Jeżeli więc ten trud zostanie świadomie lub nieświadomie wyeliminowany, twórczość reżyserów azjatyckich pozostanie dla Europejczyków (jak to się zresztą dzieje) tylko ciekawostką.

\section{Estetyka chińska - między prawdą a atrakcją}

Zrozumienie fenomenu kina azjatyckiego na Zachodzie poprzedza konieczność rozpoznania elementów sztuki chińskiej, które fascynują Europejczyków. W wymiarze ogólnym chodzi o następujące jakości światopoglądowo-estetyczne:

a) porządek i związane z tą kategorią - ograniczenie;

b) harmonia i związane z tym pojęciem odwołania do religii taoistycznej i konfucjanizmu, a także relacje między: człowiekiem i naturąa ${ }^{10}$, pierwiastkiem żeńskim (yin) i męskim (yang), realnością i iluzją;

c) w końcu witalność.

Przez Michella Sullivana określane są one jako „estetyczne ideały, które ukształtowały, zarówno wyobrażenie o sztuce chińskiej, jak i odcisnęły wyraźne piętno na sztuce zachodniej" ${ }^{11}$. Są to kategorie bardzo ogólne, których rozumienie sil-

10 Dla przykładu kompozycja filmu Zawieście czerwone latarnie odpowiada kolejnym porom roku: lato, jesień itp. Podobny chwyt kompozycyjny użyty został w filmie Wiosna, lato, jesień, zima... i wiosna Kim Ki-duka z 2003 r.

11 M. Sullivan, Sztuka chińska i jej wptyw na Zachodzie, [w:] Estetyka chińska, red. A. Zemanek, tłum. B.S. Zemanek, Kraków 2007, s. 349. 
nie związane jest z tradycją chińską. Nie sposób przenosić ich automatycznie do sztuki filmowej, ale warto zastanowić się nad ich interpretacją przed przystąpieniem do analizy.

Rysunek 2. Cesarzowa Wu Zetian i cesarz Taizong
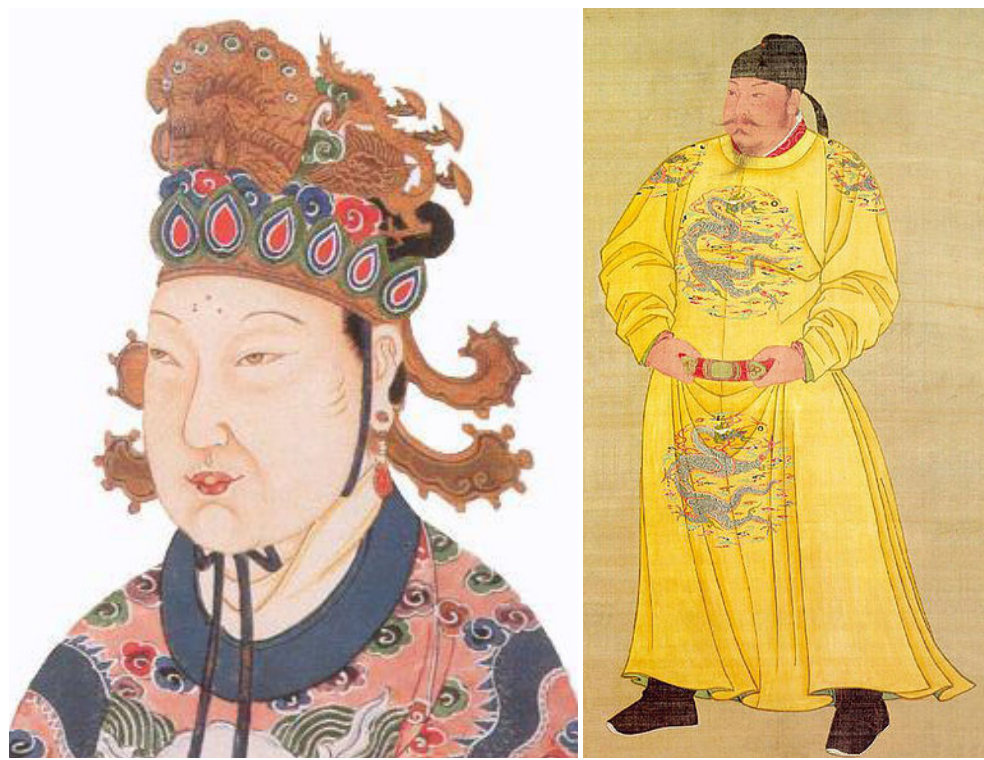

Źródło: domena publiczna.

W wymiarze szczegółowym istotna jest przede wszystkim egzotyka, na którą składa się fascynacja historią i estetyką odległego kraju oraz jakości formalne, które umożliwiają ukazanie go w wyidealizowany sposób. Warto ponadto zauważyć, że z porządkiem w tradycyjnym rozumieniu łączyć należy dwa omawiane filmy Zawieście czerwone latarnie (1990) i Cesarzowa (2006), z harmonią - wczesne prace tego reżysera (m.in. Czerwone sorgo), a z witalnością ostatnie (Bohater, Dom latajacych sztyletów). W kontekście twórczości Zhanga Yimou ważna jest fascynacja estetyką chińską, a więc też kolorytem 
lokalnym: przestrzenią i czasem. Czas akcji filmów: Zawieście czerwone latarnie - to Chiny z lat 20. XX w.; Cesarzowa Chiny z czasów dynastii Tang (był to złoty wiek sztuki i poezji chińskiej, oznaczający też otwarcie się tego kraju na świat, przypadał na lata: 618-907 n.e.). Kolejną fascynującą kwestią są niespotykani bohaterowie. W filmach Zhanga Yimu przede wszystkim kobiety, w których rolę wciela się muza tego twórcy Gong Li. Chodzi o młodą studentkę i cesarzową, która zwykle porównywana była do Wu Zetian. Istotne były relacje między bohaterami, odmienne od tych, które znane są w kulturze europejskiej, a więc kobieta w feudalnym społeczeństwie chińskim, problem konkubinatu, które podejmowane są w filmie Zawieście czerwone latarnie.

Wpływ sztuki chińskiej na kulturę zachodnią wiąże się przede wszystkim z poczuciem estetycznym. To reakcja na egzotyczne formy jest tym czynnikiem, który fascynuje Europejczyków i Amerykanów. Jest to jednak również najbardziej powierzchowne podejście do tej kultury. Michael Sullivann zauważył: „Reakcja estetyczna to reakcja przede wszystkim na formę; w pierwszej chwili niewiele mają wspólnego z celem dzieła sztuki, jego tematem, zawartością czy historią. Jednakże dobrze jest znać tło kulturowe sztuki, nie tylko ponieważ wzbogaca to nasz jego odbiór, lecz także ponieważ pozwala nam dostrzec w dziele wskazówki do zrozumienia danej cywilizacji lub sposoby porównywania cywilizacji między sobą. Z pewnością sztuki chińskiej nie sposób oddzielić od cywilizacji, która ją stworzyła"12.

Z kategorią porządku w sztuce można wiązać ograniczenie, które z kolei odsyła do ograniczeń związanych z określonymi konwencjami, technikami i formami. Ograniczenie wiązać należy z dobrem społecznym i dobrem sztuki. Zdaniem Michaela

12 Ibidem, s. 349. 
Sullivana istnieje granica, poza którą wolność jednostki musi ustąpić harmonii i spójności społeczeństwa.

Fascynacja porządkiem, harmonią i witalnością w kulturze chińskiej sprowadza się do próby opisu tych elementów w następujących sferach:

a) sztuce portretowania cesarzy;

b) sztuce kształtowania przestrzeni;

c) zdobnictwie artystycznej - a więc symbolice kształtów i barw oraz kaligrafii chińskiej ${ }^{13}$.

Sztuka portretowania cesarzy ma w Chinach bogatą tradycję. Warto się jej przyjrzeć przede wszystkim z uwagi na podjęty temat w filmie Cesarzowa ${ }^{14}$, jak i klasyczny sposób ukazywania postaci (malarska perspektywa linearna). W sztuce filmowej Zhanga Yimou jednym z przykładów są zbliżenia czy plany amerykańskie stosowane w prezentowaniu głównych bohaterek w filmie Zawieście czerwone latanie (w pomieszczeniu jadalnym, w którym przybywają żony również pojawiają się portrety, tym razem chodzi o podobizny przodków). Jest to zupełnie inny sposób prezentowania bohatera, wyraźnie klasyczny, a nie współczesny, który charakterystyczny jest dla filmów na przykład innego Azjaty Wong Kair-Waia (Upadte anioty, Changing Express).

13 Zob. M.W. Künstler, Pisownia chińska, Warszawa 1970.

14 Filmowa bohaterka jest wzorowana na postaci historycznej, cesarzowej Wu Zetian. Pochodziła ona z rodziny królewskiej za panowania dynastii Tang. Kiedy miała 13 lat dołączyła do haremu cesarza Taizonga, a potem jego następcy Gaozonga. W końcu stała się mistrzynią manipulacji. Przekonała cesarza, aby przydzielił jej pozycję tuż za cesarską małżonką, co doprowadziło do tego, że cesarz ożenił się z Wu Zetian. Nowa władczyni wprowadziła władzę tzw. silnej ręki. W końcu ogłosiła się pierwszą władczynią w historii Chin. Rządziła do 80. roku życia. Mimo że jej droga do władzy była bezwzględna, jej rządy były łagodne. Zmniejszyła liczebność armii, a zamiast arystokracji zatrudniła w rzędzie uczonych. Uczciwie traktowała chłopów, obniżając podatki i zwiększając produkcję rolną. Walczyła o podniesienie statusu kobiet i zlecała uczonym spisanie biografii znanych kobiet. W Cesarzowej najbardziej malownicze sceny dotyczą święta Chong Yang - inaczej święta chryzantem. 
Fot. 1. Ujęcia portretowe Gong Li jako cesarzowej z filmu Cesarzowa (2006)
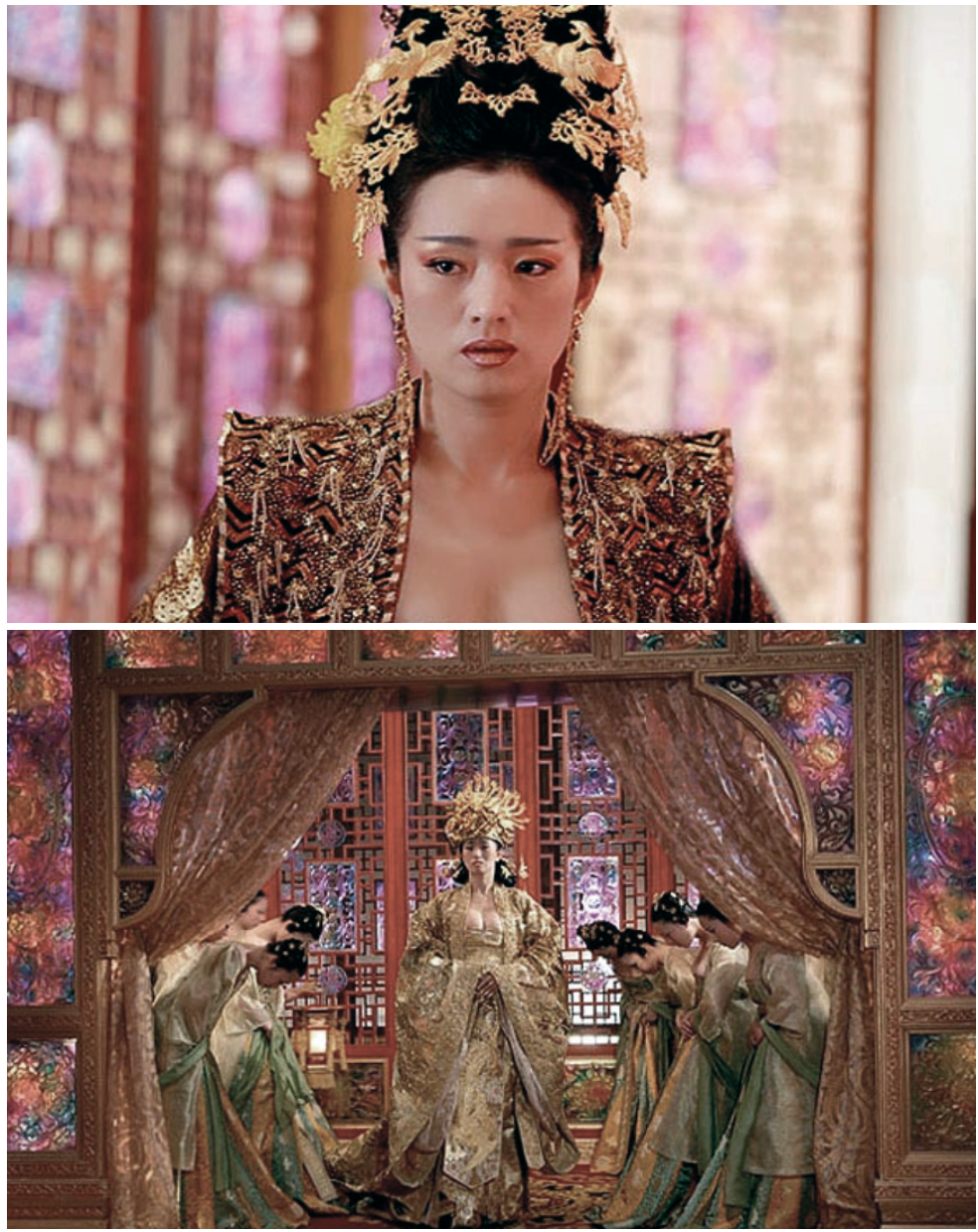

Źródło: domena publiczna.

W omawianych filmach wiele jest scen, zbliżeń, które - poprzez ukazanie postaci w strojach paradnych, zgodnie z perspektywą centralną - bliskie są tradycji chińskiego przedstawiania dostojników państwa. W tym miejscu, w rozważaniach 
szczegółowych, trzeba skupić się na ciekawych dla widzów postaciach z historii czy nieznanych nam relacjach damsko-męskich w Chinach lat 20. - problem wielożeństwa. Najciekawszą kwestią pozostaje uczynienie kobiety główną postacią tych filmów. Mężczyzna albo nigdy nie zostaje pokazany, pozostaje postacią „bez twarzy” albo jest bohaterem, którego postępowanie pozwala nam lepiej poznać główną postać kobiecą ${ }^{15}$. Taki stan rzeczy pozwala skupić się na dwóch innych zagadnieniach ważnych dla tej twórczości, a jednocześnie fascynujących zachodnich widzów: związek artysty-reżysera z jego muzą (Gong Li), który okazuje się kluczem do zrozumienia tej twórczości, a także próba wpisania tej artystycznej działalności w kontekst women studiem (w tym krytykę feministyczną). Reżyser otwarcie stwierdzał, że jest bardzo daleki od tego drugiego kontekstu, niemniej, tematyka i sposób jej prezentacji umożliwia też takie podejście.

Sztukę kształtowania przestrzeni artystycznej w omawianych filmach wiąże się przede wszystkim z cudami dziedzictwa światowego, takimi jak: zakazane miasto, mur chiński czy sztuka chińskich ogrodów. Na film Zawieście czerwone latarnie niewątpliwy wpływ miało modelowanie przestrzenne, związane z porządkiem i harmonią, które kojarzą się z przestrzeniami zamkniętymi, np. sceny rozgrywające się w domu.

W drugim filmie chodzi o obszar zamknięty, wydzielony i zorganizowany według zasad nie tylko architektonicznych (trwałość, funkcjonalność, estetyka), ale i filozoficznych. Dodatkowo chodzi o zamek cesarski - a więc przestrzeń o znaczeniu politycznym i historycznym. Dlatego w kontekście omawianych filmów najciekawsze, a więc godne uwagi, będzie ukształtowa-

15 W tym miejscu warto przypomnieć chiński zwyczaj, który przez wiele stuleci obowiązywał w tym kraju, wiązania stóp dziewczynkom w celu ukształtowania z nich kwiatów lotosu. Opowiada o tym zwyczaju m.in. film dokumentalny Chiny - krępowanie stóp. 
nie przestrzeni domu, do którego przybywa Lotos - Songliang, Zawieście czerwone latarnie i zamku, w którym rozgrywa się akcja filmu Cesarzowa. W tym miejscu warto przypomnieć fascynujące dla Europejczyka zainteresowanie egzotycznym kolorytem lokalnym tego kraju, a więc obcością, która wyrażona jest z myśleniem o przestrzeni i jej modelowaniu. Chodzi przede wszystkim o takie kategorie, jak dominacja przestrzeni zamkniętych, uporządkowanych, o wyraźnie symbolicznym charakterze (tzw. przestrzeni kaligraficznej) $)^{16}$.

\section{空間 家城堡關閉}

Znaki oznaczający przestrzeń, dom, zamek i zamknięcie

W filmie Zawieście czerwone latarnie: będą to domy czterech żon, które ułożone są w kwadrat, a także ukryte miejsce, w którym dokonywano egzekucji niewiernych żon. Przypominają też znaki chińskie oznaczające przestrzeń i zamknięcie. W Cesarzowej o meandryczne ukształtowanie wnętrza pałacu, np. korytarzy, rozkładu pokoi, a także placu przed zamkiem, na którym odbywa się święto chryzantem. Przestrzenne modelowanie w tym filmie przypomina scenografię teatralną, a więc cechuje go sztuczność i widowiskowość, które zastępują prawdę historyczną.

Dla widzów zachodnich ciekawym obszarem w sztuce, a więc i w filmie chińskim, jest zdobnictwo artystyczne, np. ornamentyka na naczyniach, hafciarstwo czy kaligrafia chińska. Ten element fascynacji Europejczyków kulturą chińską łatwo wskazać przede wszystkim w niezwykle wybujałym wizualnie filmie Cesarzowa. Chodzi zarówno o stroje aktorów ${ }^{17}$, jak

16 Z. Baihun, Świadomość przestrzeni wyrażona w chińskiej i zachodniej technice malarskiej, [w:] Estetyka chińska, op.cit., s. 289.

17 Na temat można dowiedzieć się sporo z materiałów dodatkowych dołączonych do filmu. 
i „przedmioty grające” w tym filmie: kielichy, miecze, haftowane serwety itp. Niezwykle ważna okazuje się też symbolika kwiatów, np. chryzantem (Cesarzowa) i lotosu (Zawieście czerwone latarnie). Istotna jest także symbolika barw w kulturze chińskiej, szczególnie: czerwieni (chodzi o wprowadzone przez reżysera, niezależnie od pierwowzoru literackiego, lampionów w pierwszym omawianym filmie ${ }^{18}$ ), niebieskiego i żółtego (a właściwie złotego w ostatnim). Czerwony w Chinach kojarzy się zarówno z rewolucją jak i namiętnością. W „Studiach Filmoznawczych” (2007) i „Kwartalniku Filmowym” (2009) Alicja Helman dokonuje dokładnej analizy kontekstów plastycznych i literackich w tej twórczości ${ }^{19}$.

Reżyser w jednym z wywiadów mówił: „Lubię czerwony kolor. Prawdopodobnie ma to coś wspólnego z miastem mojego dzieciństwa. Odkąd tylko zacząłem interesować się sztuką, dostrzegłem, że kolor czerwony jest szczególnie faworyzowany w rejonie Żółtej Rzeki - na obszarach wiejskich odrywa istotną rolę we wszystkich aspektach składających się na codzienne życie. Głęboka ekspresja sztuki ludowej, którą znajdujemy w obrzędach, wyraża się poprzez czerwień. Lubię czerwień także dlatego, że lubię to, co intensywne, posłużenie się czerwienią szybko nadaje tworzonej scenie ów intensywny wyraz" ${ }^{20}$. Ostatecznie zostają one zakryte - znak żałoby - czarnym płótnem. Miłość w tym filmie przypomina rytuał. Czerwień latarń można odczytać także jako symbol defloracji. Z kolei pojawienie się koloru złotego w filmach Yimou Cesarzowa (wcześniej Judou) Alicja Helman wiąże z wpływem sztuki hinduskiej na malarstwo chińskie - styl nóng cài huà (malarstwo bogatego koloru).

18 Chodzi o powieść Żony i konkubiny Su Tonga, tłum. D. Sękalska, J. Szydłowska, Warszawa 2008.

19 A. Helman, Inspiracje literackie we wczesnej twórczości Zhanga Yimou, „Studia Filmoznawcze” 2007, nr 28, s. 9-25.

20 Cyt. za eadem, Wiejskie kino Zhanga Yimou, op.cit., s. 26. 
Z tą sferą filmowego uporządkowania wiążę się stylistyka filmu, a więc zainteresowania zdjęciami eksponującymi barwność świata, który jest dzisiaj przecież zupełnie inny. Ważną kwestią jest też problem dualizmu związanego z takimi kategoriami, jak pustka i pełnia w tej sztuce ${ }^{21}$. Chodzi o dwuznaczność tych pierwiastków opisu fenomenu sztuki chińskiej. Pojęcie pustki najtrafniej zinterpretować odwołując się do rozumienia tego pojęcia w kontekście filmu Zawieście czerwone latarnie (1990). Pojęcie pełni znajduje swoją realizację w Cesarzowej (2006).

Fenomen obrazów chińskich polega też na tym, że nie ma w nim ram. Oznacza to, że obrazy są bliskie obrazom filmowym, które funkcjonują tylko w ruchu. Można ten fakt wiązać, nie tylko z pojęciem pustki i pełni, ale także ograniczoności. Paradoks polega na tym, że w sensie zewnątrzfilmowym chodzi o filmowość sztuki chińskiej. Natomiast w sensie wewnątrzfilmowym o fabularny aspekt filmów, ograniczenie kobiety przez zamknięcie jej w domu, pałacu itp. Ta cecha chińskiego obrazowania częściowo uzasadnia też wspomniany już witalizm.

Ostatnią kwestią pozostaje muzyka w filmach Zhanga Yimou. Pierwszy film wyraźnie zakotwiczony jest w tradycji chińskiej. Muzykę do niego skomponował Jiping Zhao i Naoki Tachikawa. Jedną z bohaterek jest ponadto była śpiewaczka operowa. Reżyser wykorzystał w nim tradycyjne instrumenty chińskie, np. cytrę i flet. W drugim filmie muzyka wyzbyta została niemal z cech charakterystycznych dla kultury chińskiej. Jest niesłyszalna. s. 265.

21 F. Cheng, Pustka w chińskim malarstwie, [w:] Estetyka chińska, op.cit., 


\section{Artysta i muza: Zhang Yimou i Gong Li}

Zhang Yimou urodził się w 1950 r. (inne źródła podają datę 1951 r.). Jako nastolatek był świadkiem rewolucji kulturalnej Mao Zedonga. Pochodził z rodziny podejrzanej klasowo, dlatego musiał pracować na wsi, a następnie w fabryce. Początkowo interesował się malarstwem, fotografiką, co wyjaśnia przykładanie dużej uwagi do warstwy wizualnej w filmach. Piotr Kletowski pisał o nim jako o reżyserze-malarzu, co wiele wyjaśnia. Występował też jako aktor. W 1978 r. przystąpił do egzaminu do Szkoły Filmowej w Pekinie. Studia ukończył w 1982 r. Pracę Yimou rozpoczął od realizacji zdjęć do filmu Chena Kaiga Żótta ziemia z 1984 r. Jest to też czas narodzinach chińskiej nowej fali. Stało się to dwadzieścia lat później niż w Europie ${ }^{22}$.

Najważniejsze filmy Zhanga Yimou to trylogia:

- Czerwone sorgo (1987) - pierwszy film „Piątej Generacji”, nagrodzony w Berlinie Złotym Niedźwiedziem. Jest to też produkcja, w której po raz pierwszy zagrała muza reżysera Gong Li, nazwana Gretą Garbo chińskiej kinematografii;

- Ju Dou (1990) - drugi film z wybitną aktorką kina chińskiego. Film otrzymał nominację do Oskara, ale w ostatniej chwili władze wycofały swoje poparcie. Konrad Zarębski pisał: „Powodem miała być zachodnia interpretacja filmu, ocenianego jako zamach na chińską tradycję kulturową i schlebiającego gustom zachodniego widza"23;

22 Twórca filmu Zawieście czerwone latarnie należał do „Piątej Generacji” od 1983 r., kiedy to ukończył studia filmowe, do 1989 r. - początek „Szóstej Generacji”. Piotr Kletowski zauważył: „Publiczność rodzima nigdy bardzo nie ceniła filmy twórców tego nurtu. Zdecydowanie wyżej oceniano produkcje Xie Jina, dramaty z Tajwanu czy filmy kung-fu z Hongkongu".

23 K.J. Zarębski, Artysta w kleszczach systemu, „Kino” 2003, nr 6, s. 32. 
- Zawieście czerwone latarnie (1990) - trzeci film Zhanga Yimu z Gong Li, uznany za najbardziej dojrzałe dzieło tego reżysera. Film został nagrodzony Srebrnym Lwem w Wenecji i nominowany do Oskara.

Ostatni, w kontekście zaproponowanego tematu najważniejszy, opowiada historię młodej 19-letniej studentki, która z powodów finansowych zmuszona zostaje do porzucenia marzeń o studiowaniu. Wychodzi za mężczyznę o wiele od siebie starszego, posiadającego już trzy inne żony i dzieci. Tytuł odsyła do zwyczaju zawieszania latarń wieczorem przed domem tej żony, z którą noc chce spędzić pan domu. Prawda jest jednak taka, że decyzję nie podejmuje mężczyzna, a same kobiety, które rywalizują między sobą o jego względy. Subiektywna perspektywa i losy nieznanej postaci pozwalają mimo wszystko spojrzeć na kulturę i historię Chin w szerszej perspektywie.

Kolejnymi filmami tego reżysera była Historia Qiu Ju (1992), Żyć (1994), Szanghajska triada (1995) ostatni film z Gong Li, z którą pod wpływem nacisków, personalnej krytyki reżyser postanowił się rozstać. Kolejne realizowane przez tego twórcę filmy coraz bardziej zbliżały go do widzów zachodnich. W tym czasie zrealizował:

- Wszyscy albo nikt (1999) - Złote Lwy w Wenecji;

- Droga do domu (1999) - Srebrny Niedźwiedź w Berlinie;

- Wszystkiego najlepszego (2001).

Mimo sukcesów nieustannie zarzucano reżyserowi przedstawianie fałszywego wizerunku Chin, a więc takiego obrazu, jakiego oczekuje widz zachodni. To stanowisko pogłębiły kolejne filmy: Hero (2002) - uważane przez wielu krytyków za odpowiedź na film Anga Lee Przyczajony tygrys, ukryty smok. Wskazywano także na bliskość tematyczną tego filmu z Cesarzem i zabójca Chena Kaiga z 1998 r. Kolejnym filmem był Dom latajacych sztyletów (2005). W ostatnim, monumentalnym fresku historycznym z 2006 r. reżyser powraca do Gong 
Li i historii Chin z czasów panowania dynastii cesarskich. Jest to historia cesarzowej wzorowanej na postaci historycznej: Wu Zetian. Film opowiada o jej relacji z władcą i jego trzema synami, a jednym z ważniejszych filmowych wydarzeń jest święto Chong Yang (znane też świętem podwójnej dziewiątki), bo przypada na dziewiątego września. W tradycji yin i yang owe dziewiątki są podwójnym Yang, co kojarzy się pozytywną energią i męskością. Z tym świętem łączy się motyw chryzantem, które używane są do odtruwania ludzi i wypędzania zła.

W filmie Zawieście czerwone latarnie fascynujący jest przede wszystkim temat i bohaterka. Wszystkie te elementy poetyki tego filmu związane są z pierwowzorem literackim opowiadania Su Tonga. Z perspektywy Europejczyka interesujący jest więc kontekst literacki. Dodatkowo ascetyzm formalny skłania do zainteresowania się treścią tego filmu. W Cesarzowej podobnie fascynująca jest postać i czas, który został w filmie pokazany. Z perspektywy Europejczyka ważny jest kontekst plastyczny $\mathrm{w}$ tym filmie, a więc przepych formalny skłania do zainteresowania się nim właśnie.

Podsumowując, omawiane filmy ukazują ewolucję twórczości Yimou od ascetyzmu i zainteresowania Chinami feudalnym z początku XX w., do cofnięcia się wstecz do historii tego państwa i władzy jednego niepodzielnego cesarza. $Z$ tymi tematami wiązać należy położenie nacisku na formę, za którą kryje się treść dla widza intrygująca (Zawieście czerwone latarnie) albo ukrycie za nazbyt wybujałą formą treści, które mają charakter ponadczasowy, uniwersalny (Cesarzowa). Atrakcyjność staje się cechą nadrzędną.

\section{Fascynacja kinem Zhanga Yimou w Polsce}

Wskazanie dwóch wybranych filmów twórcy Bohatera, które zrealizował on z udziałem Gong Li, ujawnia wchodzenie Zhan- 
ga Yimou na drogę kompromisu. Na ich przykładzie najlepiej widać ewolucję twórczości tego reżyser: od nieobecności tych filmów w Polsce i na świecie, do ich funkcjonowania w świadomości widza zachodniego (w tym polskiego).

Pierwszy doceniony za granicą film tego reżysera, Czerwone sorgo, miał tylko premierę światową w lutym $1988 \mathrm{r}$. Nie było premiery tego filmu w Polsce. Podobnie sytuacja wyglądała z filmem Zawieście czerwone latarnie (1991), Żyć (1994) czy Szanghajska triada (1995). Choć warto pamiętać o telewizji, w której można było oglądać te filmy w cyklu „Kocham Kino” od ok. 1995 r. Pierwszym filmem, który miał też premierę kinową w Polsce był Wszyscy albo nikt. Na świecie pokazano go we wrześniu 1999 r., a w Polsce 9 września 2001 r. Prezentowany był też w telewizji. Dopiero jednak projekty z początku XXI w., a więc Hero $(2002,2003)$, Dom latajacych sztyletów $(2004,2005)$ i ostatecznie Cesarzowa. Klatwa złotego kwiatu $(2006,2007)$ pokazane zostały na Świecie i w Polsce niemal równolegle z należytym rozgłosem.

Konrad Zarębski analizował twórczość filmową Zhanga Yimou w kontekście sytuacji politycznej Chin. W jego artykule zamieszczonym w „Kinie” (z 2003 r.) czytamy o trwającej od kil$\mathrm{ku}$ lat fascynacji kinem azjatyckim. Trudno jednak jednoznacznie orzec, czy kryje się za tym coś więcej niż tylko powierzchowna ciekawość nowości, będąca reakcją na nudę panującą w kinie europejskim. Zarębski zapytuje więc: czy kryje się za tym erupcja utalentowanych twórców kina chińskiego? Czy jest pochodną gry, jaką pekińska władza prowadzi z międzynarodową społecznością? Gry, w której stawką jest wolność twórcza tamtejszych reżyserów ${ }^{24}$. Prowadzi to do swoistego paradoksu. W centrum zainteresowania jest nie jakość prezentowanych filmów, ale trudności z ich sprowadzeniem na festiwal.

24 Ibidem. 
Twórczość Yimou podlegała krytyce nie tylko z powodu tematyki filmów czy sposobu przedstawiania Chin zachodnim widzom, ale także ze względu na sytuację osobistą reżysera. Chodziło przede wszystkim o związek z Gong Li, który nigdy nie został formalnie przypieczętowany. Jest to jednak temat na zupełnie inny tekst.

Wschód i Zachód łączy coraz częściej estetyka, a dzieli etyka. Dlatego zapewne to co fascynujące, np. dwuznaczność wszystkich elementów opisujących sztukę chińską, np. byt - niebyt, pustka - pełnia, subiektywizm - obiektywizm, może okazać się też tematem najbardziej kontrowersyjnym dla twórców i odbiorców. Michell Sullivan pisał: „Rosnące zainteresowanie orientalną filozofią i tłumaczeniem pism buddyjskich i taoistycznych uświadamiają Zachodowi chiński sposób patrzenia na świat i porządek naturalny, oraz chińskie koncepcje energii, czasu i przestrzeni. Odkrywamy, że koncepcje te mają więcej wspólnego ze światem, jaki przed nami odkrywa współczesna fizyka i psychologia, niż miała tradycyjna zachodnia kosmologia i religia. (...) Świat, który współczesna fizyka opisuje, jako realny, to nie tylko to, co namacalne i widzialne dla oka. Istnieje on raczej w tym, co nieskończenie małe i nieskończenie rozciągłe. Materia, jak teraz wiemy, istnieje w ciągłym przepływie i to, co wydaje się realne - według naszych zmysłów - jest jedynie przejściowe, lub też, jak mówią buddyści - maja iluzją. Na tym poziomie umysłu możliwe jest spotkanie Wschodu i Zachodu"25.

\section{Bibliografia}

„Film na Świecie” 1989, nr 35 (w całości poświęcony kinematografii chińskiej).

25 M. Sullivan, op.cit., s. 359. 
Helman A., Wiejskie kino Zhanga Yimou, „Kwartalnik Filmowy" 2005, nr 51.

Helman A., Kiedy komedia nie jest komedia. „Komedie” Zhanga Yimou, „Kwartalnik Filmowy” 2006, nr 56.

Helman A., Inspiracje malarskie we wczesnych filmach Zhanga Yimou, „Kwartalnik Filmowy” 2009, nr 65.

Helman A, Inspiracje literackie we wczesnej twórczości Zhanga Yimou, „Studia Filmoznawcze” 2007, nr 28.

Helman A., Zhang Yimou o sobie, „Kino” 2004, nr 6.

Kletowski P., Kino Dalekiego Wschodu, Warszawa 2008.

Zarębski K.J., Artysta w kleszczach systemu, „Kino” 2003 nr 6.

Zemanek A. (red), Estetyka chińska, Kraków 2007.

\section{Abstrakt}

Znawcy kultur azjatyckich twierdzą, że miejscem, w którym dochodzi do spotkania Wschodu z Zachodem jest poziom ontologiczny świata przedstawionego $w$ dziełach sztuki.

Tematem tekstu jest więc analiza twórczości chińskiego reżysera: Zhang Yimou, w kontekście relacji: między realnością i iluzją w jego filmach.

Celem tekstu jest odpowiedź na pytanie: „na ile atrakcyjność, metaforyczna »nadkolorowość«, ostatnich filmów autora Cesarzowej jest wynikiem "poddania się« artysty, który pragnął zaistnieć poza granicami Chin?

Metodologia: badania porównawcze, semiotyka, poetyka recepcji.

Słowa kluczowe: Zhang Yimou, kino chińskie, artysta i muza, recepcja w Polsce

Abstract

Experts of Asian cultures say that the place where East meets West is the ontological level of the world represented in works of art.

The subject of the text is an analysis of the work of the Chinese director: Zhang Yimou, in context relations: reality and illusion in his films. 
The aim of the text is the answer to the question: "how attractive, metaphorical «over-color», recent films mady Zhang Yimou is the result of an artist «surrendering» because of the desire to "exist» outside of China?

Methodology: comparative research, semiotics, reception poetics.

Keywords: Zhang Yimou, Chinese cinema, artist and music, reception in Poland 


\title{
Youyou Lu
}

\author{
Akademia Sztuk Pięknych im. Eugeniusza Gepperta \\ we Wroclawiu
}

\section{Tradycyjne chińskie symbole w chińskiej sztuce współczesnej}

W związku z procesem reform Deng Xiaopinga oraz „otwarciem Chin na świat”, rozpoczętymi w 1978 r., chińskie środowisko artystyczne stawało się coraz bardziej aktywne. Początkowy zachwyt sztuką Zachodu - głównie tą XIX i XX-wieczną przerodził się w poszukiwanie własnego stylu, ale i inspiracji rodzimą kulturą oraz sztuką. Współcześni chińscy artyści zapragnęli zbudować swoją nową tożsamość łącząc awangardowe rozwiązania z chińskimi tradycyjnymi symbolami. W niniejszym tekście zostały przytoczone i przeanalizowane różnorodne prace, odwołujące się do takich symboli, jak znaki chińskiego pisma, smok czy feniks.

W 1979 r. przed Muzeum Sztuki w Pekinie po raz pierwszy otwarto wystawę, prezentująca sztukę Gwiazd, która nie była zorganizowana przez oficjalnie działającą instytucję.

Artyści biorący udział w wystawie byli w większości amatorami zajmującymi się malarstwem, poezją i pisarstwem. Znajdowali się pomiędzy nimi również studenci z Akademii Sztuk Pięknych. Twórcy zawiesili swoje dzieła na metalowym płocie ogradzającym muzeum od wschodu. 163 prace reprezentowały takie dziedziny, jak malarstwo olejne, chińska kaligrafia, grafika oraz rzeźba. Uczestnicy zaprezentowali własny slogan brzmiący: „Poznaj świat na własne oczy, uczestnicz w świecie wraz ze 
swoimi pędzlami i nożami rzeźbiarskimi"1. Choć wystawa została zakazana po dwóch dniach, to do dziś jest postrzegana jako kamień milowy w narodzinach chińskiej sztuki współczesnej. Niektórzy krytycy sztuki uważają, że wystawa Gwiazd może być postrzegana jako początek chińskiej sztuki współczesnej, a jednocześnie symboliczne wydarzenie istotne dla niezależności współczesnych artystów chińskich.

Po 1990 r., wraz z nagłym postępem ekonomicznym Chin, nastąpił również rozwój chińskiej sztuki współczesnej, która wkroczyła w nowy etap. Także wydarzenia XXI w., od pogłębiającej się globalizacji, poprzez przystąpienie Chin do Światowej Organizacji Handlu (WTO), Letnie Igrzyska Olimpijskie w Pekinie oraz Expo w Szanghaju, wpłynęły na dynamiczne zmiany na scenie chińskiej sztuki współczesnej. Po nasileniu się komunikacji z zachodnią sztuką, twórcy chińscy przestali być usatysfakcjonowani wcześniejszymi strategiami artystycznymi, które polegały głównie na kopiowaniu artystycznych idei współczesnej sztuki Zachodu. Zaczęli sięgać do zasobów tradycyjnej kultury Państwa Środka, a także stopniowo budować własne artystyczne symbole, którymi chcieli się posługiwać na międzynarodowej arenie sztuki współczesnej. W wyniku tych działań powstało bardzo wiele prac z silnym nawiązaniami do chińskiej kultury, a także tradycyjnych symboli.

Wielu współczesnych chińskich artystów wykorzystuje znaki pisma chińskiego jako elementy swojej kreacji. Owe pisemne symbole stają się tym razem źródłem ich artystycznego języka. Zgodnie z leksykografią, chińskie znaki różnią się od łaciny oraz greki i są używane jako znaki morfemiczne. Dzięki tej funkcji chińskie sinogramy są bardziej ekspresyjne i tworzą więcej symbolicznych znaczeń dla języka sztuki.

1 星星大事记 [Xing Xing dashiji], The Stars Art, http://www.shigebao. com/html/articles/hui/3181.html [dostęp: 1.02.2019]. 
W 1988 r. artysta Xu Bing zaprezentował swoją instalację Księga $z$ Niebios w Chińskiej Galerii Narodowej w Pekinie². W pracy tej autor posłużył się znakami pisma chińskiego jako głównym narzędziem artystycznym. Wykorzystał tradycyjną technikę drzeworytniczą i własnoręcznie wyciął czcionkę opartą na tej, która była wykorzystywana za czasów dynastii Song. Xu Bing w rzeczywistości stworzył tysiące "fałszywych" chińskich znaków jedynie wyglądających jak chińskie sinogramy, były one jednak niemożliwe do rozpoznania ani do odczytania przez osoby chińskojęzyczne. Stało się tak dlatego, że artysta połączył istniejące elementy chińskich znaków w nieistniejące w rzeczywistym języku konfiguracje.

Instalacja była wystawiana pod postacią zadrukowanych "fałszywymi” znakami zwojów i ksiąg. Chińskie znaki były w użyciu przez tysiąclecia, przez co stanowiły pewnego rodzaju ograniczenie w możliwościach poznawczych ludzi, którzy się nimi posługiwali. Artysta wprowadzając zmianę do języka, jednocześnie modyfikuje najbardziej stabilne narzędzie poznawcze ludzkiego myślenia.

Pozbawione znaczenia "fikcyjne” sinogramy zostały odseparowane od podstawowej funkcji języka, jaką jest przekazywanie znaczenia i informacji przez tekst. Jednocześnie stworzone przez artystę symbole zachowują strukturę chińskich znaków, zmuszając tym samym widzów do przemyślenia i przeanalizowania sinogramów oraz tradycyjnej kultury z estetycznego punktu widzenia. W jednym z wywiadów Xu Bing stwierdził, że w tradycji Państwa Środka istnieje wiara w to, że znaki chińskiego pisma zostały podarowane przez Niebiosa-Boga. W związku z tym istnieje budząca podziw tradycja słowa. Więcej takich wątpliwości, przepisanego kontekstu, małych zmian tekstu sprawia, że takie działania są efektywniejsze ze względu

2 Gao Minglu, Total Modernity and the Avant-Garde in Twentieth-Century Chinese Art, Cambridge 2011, s. 229. 
na ludzkie myślenie. Najbardziej stała część (którą powinno być pismo i język) w tym przypadku została użyta niewłaściwie. Artysta dodał, że właśnie to jest dla niego interesujące w stworzonym tekście ${ }^{3}$.

Żyjace stowo z 2001 r. jest kolejną instalacją zaprojektowaną przez Xu Binga, w której sięga on po znaki pisma chińskiego. Sinogramy położone na podłodze galerii, układają się w tekst definicji słowa „ptak”, pochodzącej z chińskiego słownika. Od części znajdującej się na podłodze zdają się podnosić i ulatywać ku górze kolejne znaki reprezentujące słowo „ptak”. Począwszy od współczesnego, uproszczonego języka chińskiego stopniowo ewoluując do najdawniejszych znaków przypominających obrazkowe przedstawienie tego zwierzęcia. Praca przekształca współczesne i abstrakcyjne znaki chińskie w niemalże figuratywną i dynamiczną instalację będącą dziełem sztuki.

W Księdze z Niebios Xu Bing wykorzystuje jedynie dwa kolory - czerń tuszu i biel - papieru, które nadają dziełu bardziej uroczystego i poważnego charakteru, jednocześnie tworząc dystans z publicznością. W Żyjącym słowie artysta częściowo sięga także po kolory tęczy, które są dla ludzi bardziej bliskie i przystępne. Słownikowa definicja „ptaka” została utrzymana w biało-czarnej tonacji, podkreślając poważny i oficjalny ton słowa drukowanego. Natomiast tęczowe i ulatujące ku górze sinogramy odnoszą się bezpośrednio do realnego wyobrażenia ptaków, które charakteryzują się witalnością i wielobarwnymi piórami. Artysta nie tworzy jednak ostrej granicy pomiędzy słowem żyjącym i drukowanym. Wprowadza bowiem między nimi pewne przejście, które reprezentowane jest przez szare sinogramy, łączące słownikową definicję z tęczową chmarą pozostały znaków-ptaków. Łącząc słownikową definicję z naj-

3 徐冰: 父愛如山 [Xu Bing: Fu ai rushang], (film), 一条Yit [Yitiao], 2015, 5’31", https://www.youtube.com/watch?v=GYoTE87chus [dostęp: 1.02.2019]. 
dawniejszymi formami pisma chińskiego, artysta podkreśla źródło języka pisanego jakim jest obraz, jednocześnie zwracając uwagę na zagadnienie znaku-symbolu.

Ze względu na obrazową funkcję chińskich znaków teoria mówiąca o tym, że „kaligrafia i malarstwo mają wspólne pochodzenie" jest szczególnie podkreślana w tradycyjnej sztuce chińskiej. Pisane krajobrazy z himalajskiego dziennika są próbą Xu Binga w przeanalizowaniu i ponownemu zdefiniowaniu teorii poezji, istoty książki oraz malarstwa, w której skupia się na wyeksponowaniu we współczesny sposób dorobku starożytnych. Artysta używa chińskich sinogramów do dosłownego napisania obrazu. Dzieje się tak, gdyż Xu Bing w swoich dziennikach stosuje specyficzną metodę pracy polegającą na zapisywaniu całych powierzchni chińskimi znakami mającymi oddawać opisywaną materię zarówno przez słowo, jak i obraz. Dlatego słowo „kamień" pod postacią znaku - 石 - staje się ilustracją każdego "namalowanego" przez artystę kamienia. Dodatkowo Xu Bing nie „zapisuje” swojego dziennika w sposób liniowy, tworząc całe „plamy” znaków, których wielkość ma oddawać rozmiary utrwalanych na papierze obiektów. Słowo „trawa” - 草 - również oddaje na rysunku to, w którym miejscu, jak pochylone i o jakiej wielkości były kiście traw osadzonych wśród pejzażu. Artysta poprzez swoje działania porzuca tradycyjny kanon oraz ograniczenia poszczególnych stylów pisma i malarstwa, tworząc jednocześnie zupełne nowe spojrzenie na możliwości wykorzystywania kompilacji malarstwa z kaligrafią chińską.

Poza analizowaniem znaku w kontekście symbolu, współcześni artyści z Państwa Środka sięgają również po inne strategie artystyczne. Należy do nich między innymi, odwoływanie się do sztandarowych symboli istniejących od wieków w tra-

4 C. Kuo Jason, Transforming Traditions in Modern Chinese Painting. Huang Pin-Hung's Late Work, New York-Washington, D.C.-Baltimore-Bern-Frankfurt am Main-Berlin-Brussels-Vienna-Oxford 2004, s. 57. 
dycji chińskiej. Jednym z ulubionych symboli tego typu jest smok, uważany za totem narodu chińskiego. Najpierw zaistniał on w roli niebiańskiej bestii. Stopniowo przekształcając się w bóstwo i symbol pomyślności, który wpłynął na wiele aspektów kultury chińskiej ${ }^{5}$.

Smok z beczek po ropie naftowej z 2011 r. to instalacja stworzona przez artystę i kuratora Qiu Zhijie. Połączył on około siedemdziesiąt starych, podniszczonych, metalowych beczek po ropie naftowe, w których wyciął smocze łuski, rogi, oczy, brwi, wąsy, paszczę i zęby. Poskręcane cielsko smoka opiera się na łapach, ogonie i położonej na ziemi głowie. Ropa naftowa powstała w wyniku transformacji szczątków prehistorycznych zwierząt i roślin. W beczkach była więc przechowywana $\mathrm{w}$ pewnym sensie energia stworzona $\mathrm{w}$ czasach prehistorycznych, która jest niezbędnym dobrem dla współczesnego skomercjalizowanego społeczeństwa. Wraz z szybkim rozwojem chińskiej gospodarki w XXI w. społeczeństwo przeżywa także krytyczny okres przejścia od tradycji do nowoczesności. Zawarte $\mathrm{w}$ instalacji znaczenie łączy się zarówno z kontekstem tradycji, jak i nowoczesnego myślenia, które cechuje również współczesne chińskie społeczeństwo w okresie trwającej transformacji. Smok jest zatem symbolem dawnych Chin, ale materia, z której został stworzony definiuje w pewnym sensie współczesnych Chińczyków.

Wznoszacy się smok: Projekt dla obcych Nr 2 jest nieukończonym konceptem Cai Guoqianga. Artysta znany ze swoich pirotechnicznych dzieł wykorzystujących jeden z wielkich chińskich wynalazków jakim jest proch, postanowił zorganizować ogromne widowisko. Na zboczu góry Sainte-Victoire w rejonie Aix-en-Provence we Francji chciał stworzyć pokaz pirotechniczny, którego przebieg miał swoim kształtem od-

5 Wang Don, 中国龙的新发现: 中华神龙论 [Zhongguo long de xin faxian: Zhonghua shenlong lun], Beijing 2000, s. 217. 
woływać się do wzlatującego ku niebu smoka. Projekt nie doszedł do skutku ze względów bezpieczeństwa ${ }^{6}$. Cai Guoqiang wykorzystuje jednak symbolikę smoka w interesujący sposób, ponieważ staje się on symbolem łączącym dawne i współczesne idee, które towarzyszyły ludziom na przestrzeni wieków. Dzieje się tak dlatego, że smok w kulturze chińskiej jest związany zarówno ze zbiornikami wodnymi, w których mieszka, jak i niebem, czyli dwoma przestrzeniami, które od stuleci człowiek próbuje opanować. Niebo zarówno według wierzeń wyznawanych w Chinach, jak i wielu innych kulturach na całym świecie, jest zasiedlone przez wszelkiego rodzaju bóstwa. Poprzez kierunek wskazywany przez ognisty smoczy ślad, artysta jednocześnie próbował zwrócić uwagę obserwatorów nie tylko na niebo, zdobyte przez człowieka dzięki samolotom, ale wychodzi znacznie dalej we wszechświat. Z przestrzenią kosmiczną łączy się odwieczna ludzka chęć spotkania z istotami pozamiejskimi, do którego nawiązuje drugi człon tytułu projektu, jak i całego wieloletniego cyklu prac tworzonych przez Cai Guoqianga. Artysta dzięki tradycyjnemu chińskiemu symbolowi spina zatem zarówno przeszłość, jak i teraźniejszość, ale i stara się wybiec także w przyszłość.

Praca Smocza tódź to instalacja stworzona w 2002 r. przez Huang Yong Pinga. Artysta ten pochodzi z miasta Xiamen z nadmorskiej prowincji Fujian. Jednak historia smoczych łodzi w Chinach jest związana nie tylko z morzem, ale i rzekami oraz życiodajnym deszczem, którego panem i bóstwem jest właśnie postać smoka. Tradycja organizowana wyścigów smoczych łodzi jest łączona z ceremoniami mającymi uprosić boga-smoka o łaskę oraz opiekę przed powodziami, burzami i suszami. Wyścigi są też tłumaczone jako rodzaj upamiętnie-

6 Yun Cuilan, 《升龙: 为外星人作的计划第二号》1989年 [Shenglong: wei waixingren zuo de jjihua dierhao], Cai Guoqiang official website, https:// caiguoqiang.artron.net/news_detail_136878 [dostęp: 1.02.2019]. 
nia dnia śmierci starożytnego poety - Qu Yuana, który popełnił samobójstwo przez utopienie w rzece ${ }^{7}$.

Smocza łódź Huang Yong Pinga mierzy 18 metrów długości i 3 wysokości. Została zbudowana z drewna i papieru, a także dodatkowych elementów w postaci starych kufrów podróżniczych oraz różnego rodzaju lasek, mieczy, strzelb, mopów, bambusowych i golfowych kijów, próbujących zastąpić wiosła. Huang Yong Ping należał w przeszłości do grupy Xiamen Dada, która czerpała inspiracje z zachodniego dadaizmu. Owe dadaistyczne podejście ujawnia właśnie w konstrukcji łodzi. Jej drewniany stelaż pokryty jest papierem ryżowym, przez co artysta zupełnie odbiera obiektowi jego główną funkcję. Zastosowane przez artystę „wiosła” świetnie wpisują się w ready-made, również będący charakterystyczną strategią dadaizmu. Gotowe przedmioty zostały bowiem przeznaczone do użytku w innym kontekście niż ten, dla którego zostały stworzone. Jedynie kufry zdają się być na właściwym miejscu, choć stanowią archaiczną wersję bardziej współczesnych walizek.

Inna droga odczytania pracy może prowadzić bezpośrednio do charakterystyki prowincji Fujian, znanej z olbrzymiej liczby populacji, która wyjechała tworząc społeczności chińskie na całym świecie. W tym kontekście Smocza łódź symbolizuje nie tylko tęsknotę za domem, ale również wyraża eksplorację różnic kulturowych w komunikacji między Chinami a Zachodem. Może być też interpretowana jako platforma do odkrywania bezgranicznej komunikacji, która może pogodzić różne kultury.

27 marca 2010 r. na przeciwko Today Art Museum w Pekinie zwisły dwa olbrzymie Feniksy autorstwa Xu Binga, podwieszone do żurawia budowlanego. Mityczne stworzenia zostały zespawane z metalowych elementów, takich jak listwy, felgi,

7 E. Kajdański, Qu Yuan, [w:] idem, Chiny. Leksykon: historia, gospodarka, kultura, Warszawa 2005, s. 218. 
łopaty, gaśnice, wentylatory, rury, beczki, maski spawalnicze, przewody klimatyzacyjne, ale i uzupełnione o plastikowe dodatki pod postacią plandek. Obiekty, z których powstały feniksy były zwykłymi pobudowanymi odpadami, których pełno było w pekińskiej dzielnicy biznesowej. Artysta został zaproszony do współpracy z przedsiębiorcami odpowiedzialnymi za budowę w tym dystrykcie zaprojektowanego przez Cesara Pelli Światowego Centrum Finansów 8 . Początkowo rzeźby miały stanąć w reprezentacyjnym, przeszklonym holu biurowca, jednak inwestorzy ostatecznie wycofali się z projektu.

Artysta poprzez swoją instalację łączy symbol na stałe wpisany w chińską tradycję jakim jest feniks, a także definiuje kondycję współczesnych Chin i ich społeczeństwa. W tradycyjnej chińskiej kulturze zarówno feniks, jak i smok są symbolami pomyślności. Wspominany już wcześniej bóg-smok przynosi deszcz i urodzaj, natomiast feniks radość i szczęście ${ }^{9}$. Smok łączony jest z cesarzem, męską siłą oraz elementem yang, natomiast feniks jest jego przeciwieństwem i zarazem symbolem uzupełniającym, odpowiadającym cesarzowej, sile kobiecej i pierwiastkowi yin. Ich relacja oparta na przeciwstawności i wzajemnym dopełnieniu w języku chińskim oddaje czteroznakowiec 龙凤呈祥 podkreślający pomyślną symbolikę smoka i feniksa.

Xu Bing poprzez swoją instalację zdaje się łamać przypisywany feniksowi w Chinach nieskazitelny wygląd. Z perspektywy mitologii europejskiej dzieło mogłoby zostać zinterpretowane jako feniks odradzający się z budowlanych gruzów. Artysta poprzez swój projekt zwrócił jednak uwagę na grupę

8 C. Vogel, Phoenixes Rise in China and Float in New York, „The New York Times", https://cn.nytimes.com/culture/20140219/t19xubing/dual/ [dostęp: 1.02.2019].

9 Wang Evy, Cheng Loh Li, Chuah Siew Boon, Chinese Auspicious Culture, Singapore 2012, s. 108. 
społeczną jaką stanowią migrujący robotnicy, przyczyniający się poprzez swoją pracę do budowania olbrzymich „szklanych” wieżowców kreowanych na wizytówkę współczesnych Chin i symbol sukcesu gospodarczego. Podczas montowania feniksów Xu Bing pozwolił robotnikom twórczo włączyć się w powstawanie instalacji. Udowodnił, że nie są jedynie tanią siłą roboczą, ale również potrafią wykazać się kreatywnością. Dzięki feniksom artysta zwraca uwagę również na to jak kontrastowym krajem są Chiny, w których szybki proces urbanizacji przyczynił się także do ogromnych różnic w majętności i poziomie życia poszczególnych grup społecznych w Państwie Środka.

Wykorzystywanie tradycyjnych, chińskich symboli przez rodzimych artystów nie jest przypadkowe. Należy je rozpatrywać w kontekście przemyślanej strategii artystycznej, która z jednej strony ma na celu budowanie własnej tożsamości kulturowej, a drugiej zwrócenie uwagi międzynarodowej sceny artystycznej na „chińskość” twórców pochodzących z Państwa Środka. Tego typu taktyka sprawia, że artyści poddają bardzo wnikliwej analizie własne dziedzictwo, ale starają się je również „przetłumaczyć” na język sztuki współczesnej. Jednocześnie dzięki swoim pracom doskonale przedstawiają kondycję, problemy i kulturę współczesnych Chin - państwa o bogatej tradycji, które doświadcza olbrzymich przemian w XX i XXI w. ciągle pozostając w okresie transformacji. Można stwierdzić, że chińscy artyści odnaleźli swoją indywidualną drogę w zglobalizowanym świecie, a jednocześnie nie pozostali obojętni na własne dziedzictwo, które za pomocą wykorzystywanych symboli staje się ich własnym językiem artystycznym. 


\section{Bibliografia}

Gao Minglu, Total Modernity and the Avant-Garde in Twentieth-Century Chinese Art, Cambridge 2011.

Kajdański E., Qu Yuan, [w:] E. Kajdański Chiny. Leksykon: historia, gospodarka, kultura, Warszawa 2005, s. 218.

Kuo Jason C., Transforming Traditions in Modern Chinese Painting. Huang Pin-Hung's Late Work, New York-Washington, D.C.-Baltimore-Bern-Frankfurt am Main-Berlin-Brussels-Vienna-Oxford 2004.

Vogel C., Phoenixes Rise in China and Float in New York, „The New York Times", https://cn.nytimes.com/culture/20140 219/t19xubing/dual/.

Wang Don, 中国龙的新发现: 中华神龙论 [Zhongguo long de xin faxian: Zhonghua shenlong lun], Beijing 2000.

Wang Evy, Cheng Loh Li, Chuah Siew Boon, Chinese Auspicious Culture, Singapore 2012.

星星大事记 [Xing Xing dashiji], The Stars Art, http://www.shigebao.com/html/articles/hui/3181.html.

徐冰: 父愛如山 [Xu Bing: Fu ai rushang], (film), 一条Yit [Yitiao], 2015, 5’31", https://www.youtube.com/watch?v=GYoTE87chus.

Yun Cuilan, 《升龙: 为外星人作的计划第二号》1989年 [Shenglong: wei waixingren zuo de jjihua dierhao], Cai Guoqiang official website, https://caiguoqiang.artron.net/news_detail_136878.

\section{Abstrakt}

W związku z procesem reform Deng Xiaopinga oraz „otwarciem Chin na świat”, rozpoczętymi w 1978 r., chińskie środowisko artystyczne stawało się coraz bardziej aktywne. Początkowy zachwyt sztuką Zachodu głównie tą XIX i XX-wieczną, przerodził się w poszukiwanie własnego stylu, ale i inspiracji rodzimą kulturą oraz sztuką. Współcześni chińscy artyści zapragnęli zbudować swoją nową tożsamość łącząc awangardo- 
we rozwiązania z chińskimi, tradycyjnymi symbolami. W tekście zostały przytoczone i przeanalizowane różnorodne prace, odwołujące się do takich symboli, jak znaki chińskiego pisma, smok czy feniks. Wykorzystywanie tych symboli przez chińskich artystów nie jest przypadkowe. Należy je rozpatrywać w kontekście przemyślanej strategii artystycznej. Jednocześnie dzięki swoim pracom doskonale przedstawiają kondycję, problemy i kulturę współczesnych Chin pozostających w okresie transformacji. Artyści z Państwa Środka odnaleźli swoją indywidualną drogę w zglobalizowanym świecie, a jednocześnie nie pozostali obojętni na własne dziedzictwo, które za pomocą wykorzystywanych symboli staje się ich własnym językiem artystycznym.

Słowa kluczowe: współczesna chińska sztuka, tradycja, symbole, Chiny, znaki chińskiego pisma, smok, feniks

\begin{abstract}
Due to the reform process of Deng Xiaoping and the "opening of China to the world", which began in 1978, artistic communities in China became more and more active. Chinese contemporary art has gradually developed from the earliest imitation of Western art, mainly that of the 19th and 20th centuries, to finding its own characteristics and therefore many Chinese contemporary artists were engaging in building their new identity by combining avant-garde approaches with Chinese traditional symbols. In the text, I present and analyze various works of art, that refer to such symbols as Chinese characters, dragon or phoenix. The use of these symbols by Chinese artists is not accidental. They should be considered in the context of a well-thought-out artistic strategy. At the same time, through their works, they perfectly present the condition, problems, and culture of contemporary China in a period of transformation. Artists from the China have found their individual way in a globalized world, at the same time, they have not been indifferent to their own heritage, which through the used symbols becomes their own artistic language.
\end{abstract}

Keywords: contemporary chinese art, tradition, symbols, China, Chinese characters, dragon, phoenix 


\section{Katarzyna Matuszczyk-Lu}

Uniwersytet Wroclawski, Xiamen University

\section{Między tradycją a innowacją - chińska architektura współczesna}

Sztuka od wieków jest pewnego rodzaju zwierciadłem przemian zachodzących w danej kulturze czy państwie. Jednak to architektura była i jest dziedziną sztuki, która najlepiej potrafi oddać bogactwo, władzę, a także zmiany zachodzące w społeczeństwie. Twórcy architektury prześcigali się w konstruowaniu coraz to większych i wyższych budowli. Dziś chińskie miasta pełne są „szklanych wieżowców”, które mają reprezentować potęgę gospodarczą współczesnych Chin. W tym miejskim pejzażu jest na pewno wiele miejsca na projekty innowacyjne, ale czy można w nich odkryć nawiązania do chińskiej tradycji architektonicznej?

Celem artykułu jest analiza wybranych przykładów współczesnej architektury chińskiej, które poprzez różne metody odwołują się do dziedzictwa architektonicznego dawnych Chin.

Chińska sztuka współczesna zaczęła rodzić się na początku lat 80. XX w. zaraz po reformach „otwarcia Chin na świat” przez Deng Xiaopinga ${ }^{1}$. Początkowo artyści współcześni bardzo chętnie nawiązywali i inspirowali się XX-wieczną sztuką Zachodu, aby następnie wytworzyć własne indywidualne style odwołujące się także do ich natywnej kultury. Ten fenomen jest również widoczny w dziedzinie sztuki jaką jest architektu-

1 Por. E. Kajdański, Chiny. Leksykon: historia, gospodarka, kultura, hasło Deng Xiaopinga reformy, Warszawa 2005, s. 54. 
ra. Jednak w chińskiej architekturze formy nawiązujące do tradycyjnej architektury Państwa Środka były widoczne również w XX-wiecznych realizacjach budynków stworzonych przez okresem reform Denga.

Takim przykładem może być Mauzoleum przewodniczącego Mao Zedonga, którego architektura formą, proporcjami, podziałami (dach, kolumnada, platforma) i niektórymi elementami konstrukcyjnymi i dekoracyjnymi (balustrady, kafle) nawiązuje do chińskiej, tradycyjnej architektury rezydencjonalnej i świątynnej. Od strony ideowej i symbolicznej ciekawy jest również fakt zastosowania przy budowie mauzoleum Mao materiałów pochodzących z różnych części Chin. Zabieg ten był wykorzystywany wcześniej również przy tworzeniu założeń pałacowo-parkowych przeznaczonych dla chińskich cesarzy. Działania takie miały podkreślać zwierzchnictwo władcy nad wszystkimi regionami państwa, jak i przyczynić się do stworzenia pewnego rodzaju miniaturę Chin dla samego cesarza, który nie mógł ze względu na obowiązki i ówczesne możliwości transportowe podróżować po całym terytorium Państwa Środka.

O ile nawiązania do tradycyjnej architektury rezydencjonalnej i świątynnej są możliwe do prześledzenia w budynkach związanych z administracją, użytkowaniem publicznym i muzealnictwem, to we współczesnej architekturze mieszkaniowej formy tradycyjne pojawiły się stosunkowo późno, zwłaszcza w budownictwie wielorodzinnym.

Przyczyn takiego stanu jest na pewno wiele. Jako jedną z nich, można zapewne wymienić pragmatyzm architektów i inwestorów. W wielorodzinnej architekturze mieszkaniowej najważniejsza jest bowiem funkcjonalność, a kwestie estetyki czy nawiązanie do lokalnej kultury długo schodziły na dalszy plan. W dobie globalizacji zaczęły się pojawiać projekty nawiązujące do bogatej, chińskiej, lokalnej tradycji architektonicznej, 
która ma co prawda wiele wspólnych ogólnokrajowych mianowników, jednak charakteryzuje się też formami i materiałami specyficznymi dla danego regionu Państwa Środka.

Jedną z pierwszych prób stworzenia wielorodzinnej zabudowy mieszkaniowej nawiązujące do tradycji jest Ju'er Hutong Courtyard Housing Project w Pekinie, który w 1993 r. uzyskał nagrodę World Habitat Awards ${ }^{2}$. Autor projektu - Wu Liangyong - połączył w tej realizacji współczesne wymogi mieszkalnictwa z lokalną kulturą i architekturą ${ }^{3}$. Założenie to łączy w sobie zarówno ideę hutongu (胡同) - tradycyjnej chińskiej, zwartej zabudowy mieszkaniowej, jak i jego podstawowej jednostki - siheyuanu (四合院) - domu składającego się z zespołu budynków usytuowanych wzdłuż krawędzi wewnętrznego dziedzińca na planie kwadratu lub prostokąta ${ }^{4}$. W projekcje

2 Ju'er Hutong Courtyard Housing Project, Beijing, https://www. world-habitat.org/world-habitat-awards/winners-and-finalists/juer-hutongcourtyard-housing-project-beijing/ [dostęp: 27.09.2019].

3 Jianfei Zhu, Beyond Revolution: Notes on Contemporary Chinese Architecture, „AA Files” 1998, nr 35, s. 12.

4 Przylegające do siebie ściśle ścianami zewnętrznymi siheyuany, zapewniały mieszkańcom bezpieczeństwo i odizolowanie od „świata zewnętrznego", tworząc tym samym całe kwartały niskiej zabudowy mieszkaniowej - hutongi. Taki typ zabudowy był możliwy poprzez umieszczanie okien i drzwi budynków mieszkalnych (poza bramą prowadzącą do samego domostwa bezpośrednio z ulicy) skierowanych jedynie na wewnętrzny dziedziniec. Hutongi charakteryzują się obecnie starą, chaotyczną zabudową i dość niskimi standardami sanitarnymi. Bardzo często mieszkańcy mają dostęp jedynie do publicznych łazienek i toalet. Hutongi od wielu lat podlegaja mocnym przemianom. Ich liczba w dużych chińskich miastach (takich jak Pekin) gwałtownie zmalała w ostatnich dziesięcioleciach. Hutongi w większości usytuowane są w bardzo dobrych lokalizacjach, które ze względu na wysokie ceny ziemi i szybki rozrost miast są chętnie przeznaczane pod nową zabudowę. Niektóre z hutongów są rewitalizowane i przeznaczane na cele turystyczne, przez co częściowo tracą swój mieszkaniowy charakter, przyczyniając się do powolnego zaniku lokalnej kultury związanej z tego typu zabudową. Pojedyncze siheyuany w przeszłości należały głównie do jednego rodu. W wyniku braku lokali mieszkaniowych siheyuany były dzielone na mniejsze jednostki przydzielane kolejnym rodzinom. Dodatkowo dziedzińce były stopniowo zabudowywane, często w niekontrolowany sposób. Istnieją 
Wu Liangyong podjął się trudnego zadania zastąpienia starej tkanki miejskiej nową, która formą, wysokością, kolorystyką zastosowanych materiałów oraz gabarytami i metrażem miała nawiązywać do oryginalnej architektury pozostającej w sąsiedztwie. Jednak hutongi to również wymiar socjologiczny i określony styl życia - który w przypadku Ju'er Hutong Courtyard Housing Project nie do końca został odtworzony. Co prawda, część dawnych mieszkańców miała możliwość zamieszkana w nowej wersji hutonu, jednak pozostałe mieszkania zostały sprzedane na wolnym rynku, tym samym wprowadzając nowych, obcych lokatorów, którzy nie angażowali się tak bardzo w kolektywny sposób koegzystencji charakterystyczny dla lokalnej społeczności.

Inną odsłoną polepszenia sanitarnych warunków życia mieszkańców pekińskich hutongów jest Beijing Hutong Bubble z 2009 r. zaprojektowany przez MAD Architects5. Według tego założenia oryginalna tkanka architektoniczna zostaje jedynie zrewitalizowana, zachowuje w dużym stopniu tradycyjną formę i dzięki temu unika całkowitemu wyburzeniu. Istotą Beijing Hutong Bubble jest dodanie do istniejącej architektury „baniek”, w których zostaną umieszczone na przykład toalety i łazienki, które nie są standardowym wyposażeniem wszystkich domów na hutongach. Projektanci z MAD Architects nie próbują przez tradycyjną formę udawać, że dodane przez nich pomieszczenia są stare. Wręcz przeciwnie, nadają im bardzo współczesną formę nieregularnych „baniek” z polerowanej stali, które dodatkowo podbijają kontrast pomiędzy starą, a nową zabudową.

też siheyuany, które dzięki zamożnym inwestorom zostały lokal po lokalu wykupione od poszczególnych rodzin, a następnie rewitalizowane na potrzeby mieszkaniowe lub biznesowe.

5 N. Saieh, Beijing Hutong Bubble / MAD, https://www.archdaily. com/50931/beijing-hutong-bu1bble-mad [dostęp: 27.09.2019]. 
Inną propozycją MAD Architects łączącą to co "stare" i "nowe” jest pekińska realizacja Courtyard Kindergarten z 2019 r. Również w tym projekcie architekci łączą tradycyjny siheyuan datowany na 1725 r., z zupełnie współczesną formą "floating roof", pod którym ukryte zostały pomieszczenia pełniące funkcję przedszkola. Jest to kolejny dowód na to, że współczesna architektura może zostać wpisana w najbliższe otoczenie architektury dawnej. Tym samym dawna architektura nie musi ustępować miejsca nowej - mogą istnieć równocześnie tworząc współczesne chińskie miasta. Dodatkowym efektem w tym przypadku jest również fakt, że powstanie nowych budynków przyczyniło się do rewitalizacji i konserwacji starych. Przedszkole to posiada także dodatkowy efekt edukacyjny w postaci poszanowania własnej historii i kultury.

W niektórych sytuacjach architektonicznych jednak nie istnieją dawne formy, które można by zrewitalizować, a jedynie co po nich pozostaje, to gruzy po wyburzeniach. Wang Shu poprzez swoje projekty udowadnia jednak, że nawet coś co pozornie mogłoby wydawać się jedynie odpadem i bezwartościową pozostałością po nieistniejących budynkach, może nadać nowej architekturze dodatkowego znaczenia. Takim przykładem jest gmach Muzeum w Ningbo z 2008 r., którego elewacja została pokryta cegłami i dachówkami z budynków, które dawniej istniały w okolicy ${ }^{7}$. Poza bezpośrednim nawiązaniem poprzez wykorzystany materiał, Wang Shu w sposób mniej dosłowny nawiązuje także do tradycyjnych chińskich wewnętrznych dziedzińców, które zostały również ujęte w bry-

6 MAD Transforms Traditional Chinese Courtyard Into a Kindergarten With Floating Roof, http://www.i-mad.com/press/mad-transforms-traditional-chinese-courtyard-into-a-kindergarten-with-floating-roof/ [dostęp: 27.09.2019].

7 E. Chakroff, Recasting History: The Ningbo Historic Museum, „Log: Architecture Criticism" 2012, nr 24, s. 57. 
le Muzeum w Ningbo. Kolejnym ukłonem ku chińskiej tradycji są odciśnięcia bambusowych tyczek w strukturze betonu.

Wang Shu w projekcie Ceramic House w Jinhua z 2006 r., jak sam wspomina, zainspirował się formą kamieni do rozcierania tuszu oraz ceramiką i porcelaną tworzoną przez swojego przyjaciela - Zhou $\mathrm{Wu}^{8}$. Z połączenia tych dwóch inspiracji powstał współczesny dom-herbaciarnia o prostej bryle i elewacji pokrytej tysiącami ceramicznych płytek o wielokolorowych szkliwach. Poza bezpośrednimi skojarzeniami z ceramicznymi, szkliwionymi dachówkami, które w chińskiej architekturze funkcjonują od wieków, Ceramic House Wang Shu nawiązuje także do tradycji związanej z Porcelanowa Pagoda w Nankinie, której elewacja również była pokryta porcelanowymi płytka$\mathrm{mi}^{9}$.

Wang Shu w swojej twórczości wykazuje nie tylko fascynację tradycyjnymi materiałami architektury chińskiej, ale także konstrukcją. W projekcie Guesthouse z 2013 r. znajdującym się na terenie nowego kampusu Chińskiej Akademii Sztuk Pięknych w Hangzhou ${ }^{10}$, wyraźnie widać inspirację chińskimi, drewnianymi konstrukcjami dachów, które posiadają nie tylko funkcję podtrzymywania poszycia dachowego i przenoszenia jego ciężaru na podpory, ale również ze względu na bogatą formę rzeźbiarską mają także funkcje dekoracyjne. Wang Shu nie zastosował bezpośrednio tradycyjnej konstrukcji chińskiego dachu, która opiera się głównie na idealnie dopasowanych elementach drewnianych. W swoim projekcie wykorzystał bo-

8 Ceramic House, https://www.german-architects.com/pl/projects/ view/ceramic-house [dostęp: 27.09.2019].

9 Elaine Yu, China rebuilds a 'world wonder' in Nanjing, http://edition. $\mathrm{cnn}$.com/travel/article/nanjing-china-reconstructed-porcelain-tower/index. html [dostęp: 27.09.2019].

10 Wang Shu, Wa Shan - The Guesthouse on Xiangshan Campus, https://www.area-arch.it/en/wa-shan-the-guesthouse-on-xiangshan-campus-2/ [dostęp: 27.09.2019]. 
wiem belki stropowe połączone metalowymi nitami. Mnogość elementów drewnianych w konstrukcji dachu zaprojektowanego przez Wang Shu, przypomina również bogatą formę konstrukcji w typie dougong (斗拱).

Podobna reinterpretacja chińskiej konstrukcji dachowej i dougong towarzyszyła również He Jingtang - twórcy Pawilonu chińskiego na Expo 2010 w Szanghaju, pragnącego podkreślić „chińskość” owej budowli ${ }^{11}$. He Jingtang zaprojektował budynek, który w dolnej części odwołuje się do formy ding (鼎) - rytualnego naczynia z brązu o czterech nogach, a w górnej do piętrzącej i poszerzającej się formy belek z konstrukcji dougong. Poza głęboką symboliką, którą nadał budowli architekt, należy również podkreślić zastosowaną kolorystykę - w tym przypadku czerwień - która w nieco innym odcieniu jest obecna między innymi w zabudowie Zakazanego Miasta. Innym aspektem, który nawiązuje do architektury chińskiej, a dokładniej chińskich ogrodów jest New Jiuzhou Qing Yan - ogród na dachu Chinese Joint Provincial Pavilion odwołujący się do jednego z widoków w Starym Pałacu Letnim Yuanmingyuan ${ }^{12}$. Niewątpliwie jednak pawilon Chin na Expo działa na widza nie tylko poprzez swoją „chińskość”, ale i poprzez zastosowaną ogromną skalę.

Architektem, który w swoich realizacjach łączy dużą skalę z niektórymi ideami tradycyjnej chińskiej zabudowy jest - Liu Jiakun. W realizacji West Village z 2015 r. w Chengdu, nawiązuje bardzo niebezpośrednio do kilku elementów składowych chińskiej architektury. West Village to olbrzymi kompleks, który zajmuje cały kwartał ziemi w sąsiedztwie osiedli mieszkaniowych. Realizacja początkowo wydaje się nie mieć żadnych

11 Lu Yuan, 2010 Expo: He Jingtang and the China Pavilion, http://english.cri.cn/6909/2010/01/21/1781s544131.htm [dostęp: 27.09.2019].

12 He Jingtang, China Pavilion, https://www.area-arch.it/en/china-pavilion/ [dostęp: 27.09.2019]. 
punktów wspólnych z architekturą tradycyjną, a jednak istnieją one w zinterpretowanej przez architekta formie.

Pierwszym punktem wspólnym jest zamknięty we wnętrzu ogromny dziedziniec ${ }^{13}$, otoczony ze wszystkich stron budynkami należącymi do całego kompleksu oraz rampami łączącymi poszczególne kondygnacje. Dzięki dużej powierzchni dziedzińca zmieściło się na nim wiele pomniejszych, wydzielonych elementów, takich jak plac z bambusami czy boiska do gry w piłkę nożną. Tym samym architektura kompleksu nawiązuje do wewnętrznych dziedzińców siheyuanów, które również stanowiły przestrzeń wspólną wszystkich mieszkańców oraz niejednokrotnie były wypełnione roślinnością, a zwłaszcza bambusami. Poprzez formę zabudowa West Village może być zatem interpretowana jako ogromny siheyuan. Natomiast ze względu na funkcje można ją rozpatrywać jako rozszerzoną wariację na temat przestrzeni dziedzińca siheyuanu, w której domownicy należący do jednego rodu zostali niejako zastąpieni przez całą społeczność mieszkającą w okolicy. Inną możliwością jest interpretowanie West Village w kontekście całego hutongu, który również jest specyficznym tworem, scalającym daną społeczność poprzez architekturę, w której ludzie mieszkają i funkcjonują na co dzień. Ciekawym zabiegiem odnoszącym się do detali jest ułożenie na dachu całego kompleksu pomalowanych na czarno pustaków wypełnionych ziemią, z której wyrastają źdźbła trawy - przypominają one rzędy ceramicznych dachówek pokrywających dachy siheyuanów, które czasami również porasta drobna roślinność w postaci mchów lub niewielkich kępek trawy.

Liu Jiakun zdaje się zatem projektować architekturę dopasowaną do skali, materiałów i potrzeb XXI-wiecznych Chin. Nie zapomina jednak o tradycji i dziedzictwie, które poddaje twórczej interpretacji scalając przeszłość ze współczesnością.

13 West Village - Basis Yard / Jiakun Architects, https://www.archdaily. com/880868/west-village-basis-yard-jiakun-architects [dostęp: 27.09.2019]. 
Współcześni chińscy architekci odwołują się do tradycyjnej architektury chińskiej na różne sposoby i z wykorzystaniem różnych metod. Czasami ich nawiązania są bardzo bezpośrednie, a w innych przypadkach jedynie szczątkowe lub poddane daleko idącej interpretacji. Projektanci często korzystają z tradycyjnych form architektury chińskiej, takich jak założenia typu siheyuan. Bardzo chętnie wykorzystują materiały funkcjonujące od wieków w chińskim budownictwie. Są to między innymi cegły, dachówki, konstrukcje drewniane, które stanowią główne elementy projektowanych budynków lub jedynie ich akcenty. Niezależnie od skali, specyfiki i funkcji realizacji, chińscy architekci potrafią wprowadzić elementy nawiązujące do tradycji, która stanowi część dorobku kulturowego Chin, a także jest składową tożsamości kulturowej Chińczyków. Zatem z jednej strony współcześni chińscy architekci podtrzymują istnienie idei tradycyjnej architektury, a z drugiej dopisują do niej własny, innowacyjny rozdział. Tym samym udowadniają, że przeszłość może być współcześnie szanowana, kontynuowana i rozwijana, nie tylko dla pamięci i dokonań przodków, ale i dla kolejnych pokoleń, które również w przyszłości będą stawiać sobie pytania o własną tożsamość kulturową oraz otaczającą przestrzeń architektoniczną.

\section{Bibliografia}

Ceramic House, https://www.german-architects.com/pl/projects/view/ceramic-house.

Chakroff E., Recasting History: The Ningbo Historic Museum, „Log: Architecture Criticism” 2012, nr 24.

He Jingtang, China Pavilion, https://www.area-arch.it/en/china-pavilion/.

Ju'er Hutong Courtyard Housing Project, Beijing, https://www. 
world-habitat.org/world-habitat-awards/winners-and-finalists/juer-hutong-courtyard-housing-project-beijing/.

Kajdański E., Chiny. Leksykon: Historia, gospodarka, kultura, Warszawa 2005.

Lu Yuan, 2010 Expo: He Jingtang and the China Pavilion, http://english.cri.cn/6909/2010/01/21/1781s544131.htm.

MAD Transforms Traditional Chinese Courtyard Into a Kindergarten With Floating Roof, http://www.i-mad.com/ press/mad-transforms-traditional-chinese-courtyard-into-a-kindergarten-with-floating-roof/.

Saieh Nico, Beijing Hutong Bubble / MAD, https://www.archdaily.com/50931/beijing-hutong-bubble-mad.

Wang Shu, Wa Shan - The Guesthouse on Xiangshan Campus, https://www.area-arch.it/en/wa-shan-the-guesthouse-on-xiangshan-campus-2/.

West Village - Basis Yard / Jiakun Architects, https://www. archdaily.com/880868/west-village-basis-yard-jiakun-architects.

Yu Elaine, China rebuilds a 'world wonder' in Nanjing, http:// edition.cnn.com/travel/article/nanjing-china-reconstructed-porcelain-tower/index.html.

Zhu Jianfei, Beyond Revolution: Notes on Contemporary Chinese Architecture, „AA Files” 1998, nr 35.

\section{Abstrakt}

Architektura od wieków jest dziedziną sztuki, która najlepiej potrafi oddać bogactwo, władzę, a także zmiany zachodzące w społeczeństwie. Twórcy architektury w różnych zakątkach świata prześcigali się w konstruowaniu coraz to większych i wyższych budowli. Dziś chińskie miasta pełne są „szklanych wieżowców”, które mają reprezentować potęgę gospodarczą współczesnych Chin. W tym miejskim pejzażu jest dużo miejsca na projekty innowacyjne, których autorami są często znani zachodni architekci. W wyścigu kreowania wyglądu współczesnych chińskich miast, biorą również udział rodzimi architekci, którzy bez obaw 
wykorzystują cytaty z przeszłości, aby nawiązać do chińskiej tradycji architektonicznej. Celem artykułu jest analiza wybranych przykładów współczesnej architektury chińskiej, które poprzez różne metody odwołują się do dziedzictwa architektonicznego dawnych Chin.

Słowa kluczowe: współczesna chińska architektura, tradycja, dziedzictwo, innowacja, Chiny

\begin{abstract}
For many centuries architecture has been a field of art that best reflects wealth, power, and changes in society. Creators of architecture in various places of the world outdo each other in constructing larger and higher buildings. Today, Chinese cities are full of "glass skyscrapers" that are supposed to represent the economic power of contemporary China. In this urban landscape there is a lot of space for innovative projects, whose authors are often well known western architects. Native architects also take part in the race to create the image of a contemporary Chinese cities. They are not afraid of using quotes from the past to refer to the Chinese architectural tradition. The aim of the article is to analyze selected examples of contemporary Chinese architecture, which by various methods refer to the architectural heritage of China.
\end{abstract}

Keywords: contemporary chinese architecture, tradition, heritage, innovation, China 


\section{Helena Jadwiga Błazińska}

Katolicki Uniwersytet Lubelski Jana Pawła II

ORCID ID: https: / / orcid.org/ 0000-0001-5741-6582

\section{System nauczania w dawnych Chinach}

Na wstępie należy zaznaczyć, że w literaturze przedmiotu pismo chińskie jest uznawane za najstarsze z używanych aktualnie na świecie systemów piśmienniczych ${ }^{1}$. Sam zaś system formował się przez ponad $3000 \mathrm{lat}^{2}$. Jeszcze przed wynalezieniem pisma wiedza przekazywana była ustnie z pokolenia na pokolenie. W czasach dynastii Shang (1600-1046 p.n.e.) pojawiły się szkoły dla arystokracji, do których mogli uczęszczać zarówno dorośli, jak i chłopcy z bogatych rodów. Istotna zmiana nastąpiła w czasach dynastii Zhou (1046-221 p.n.e.), kiedy to pojawił się podział na szkoły dla biednych i bogatych, nazywane także szkołami wschodnimi i zachodnimi.

Warto dodać, że w dawnych Chinach podstawę nauczania i wychowania stanowiły klasyczne księgi, których autorem był Konfucjusz ${ }^{3}$ oraz jego wyznawcy ${ }^{4}$. Księgi te (w liczbie trzydziestu) przez ponad dwa tysiąclecia były uważane za święte. Traktowano je jako kanon, zgodnie z którym wychowywano

1 Zob. Wu Lan, Nauczyciel w Chinach - wczoraj $i$ dziś, [w:] eadem, Z notatnika tłumacza literatury polskiej i chińskiej, Gdańsk 2019, s. 207-217.

2 Por. H.A. Ross, Contemporary education system, [w:] Education in China. Educational History. Models and initiatives, red. Q. Zha, Great Barrington 2013.

3 I. Sławińska, H. Peijang, Chińszczyzna, Toruń 2004, s. 22-31.

4 Por. J.D. Sellmann, Confucian ethics, [w:] Education in China. Educational History. Models and initiatives, red. Q. Zha, Great Barrington 2013, s. 13. 
i nauczano we wszystkich szkołach Państwa Środka. W swej treści zawierały one zasady postępowania i administrowania państwem, normy moralne i obyczajowe, które były powszechnie znane w ówczesnym społeczeństwie. Utwory te miały tak wielkie znaczenie, gdyż w szkołach Chin feudalnych zastępowały wszelkie pomoce dydaktyczne. Nauczenie się zaś chińskiego języka literackiego służyło tylko i wyłącznie jednemu celowi - opanowaniu czytania wspomnianego wyżej kanonu konfucjańskiego. Sama zaś umiejętność czytania i pisania w dawnych Chinach była utożsamiana z mądrością, olbrzymim wysiłkiem i świetną pamięcią, ponieważ trzeba było poznać kilka tysięcy znaków, aby móc czytać kanon. Nie sposób wskazać, jaka była dokładna liczba znaków w chińskim alfabecie. Materiały źródłowe mówią o 44449 znakach $^{5}$. Wyodrębniła się wówczas sztuka pięknego pisania - kaligrafia ${ }^{6}$. Z tego względu każdy, kto posiadał bardzo dobre wykształcenie i stopień naukowy mógł posługiwać się znakami w liczbie od 8 do 10 tys. Ten Chińczyk, który był słabo wykształcony, z reguły opanowywał jedynie kilkadziesiąt najpopularniejszych znaków, niezbędnych w życiu codziennym. Problem stanowiło nie tylko trudne pismo hieroglificzne, lecz także różnica między językiem literackim i potocznym oraz istnienie kilku odmiennych od siebie dialektów. Omawiana tu trudność w przyswajaniu tajników języka chińskiego dała asumpt do postawienia tezy o wyższości tego języka nad innymi ${ }^{7}$. Warto tu zacytować angielskiego sinologa i dyplomaty Herberta A. Gilesa ${ }^{8}$, który pi-

5 Słownik K,ang-sicy-tien.

6 Oprócz kaligrafii do sztuk zaliczano muzykę, liczenie, etykietę, strzelanie z łuku, a także kierowanie końmi.

7 Wówczas powstało wyrażenie: „mówić w ludzkim języku”, co pojmowano jako "mówić po chińsku".

8 Herbert Allen Giles (1845-1935) był specjalistą od starożytnej literatury chińskiej. Zmodyfikował system latynizacji języka chińskiego. Napisał wiele podręczników do nauki języka chińskiego, opracował kilka pozycji na 
sał: „Ich własny język wydaje się językiem bogów; wiedzą, że władają nim od kilku tysięcy lat”.

\section{Nauczanie w szkołach}

W latach 1644-1911, gdy panowała mandżurska dynastia Qing, w Chinach funkcjonowały szkoły państwowe i prywatne9. Placówki państwowe dzieliły się na: a) szkoły pierwszego stopnia sze-sue, które istniały we wsiach; b) szkoły powiatowe stopnia drugiego; c) szkoły okręgowe; d) szkoły prowincjonalne.

Nauka w wymienionych szkołach była odpłatna. Każdy z uczniów zaczynał swoją edukację w wieku siedmiu lub ośmiu lat. Przekraczając próg szkoły należało pokłonić się wizerunkowi Konfucjusza oraz nauczycielowi, który odtąd aż do końca nauki stawał się duchowym przewodnikiem wychowanka ${ }^{10}$. Oprócz trzykrotnego pokłonu przed nauczycielem, chłopiec powinien był zapalić także kadzidła na jego cześć. Były to wyrazy szacunku i oznaka bezwzględnego posłuszeństwa wobec mentora. Po dopełnieniu tego ceremoniału uczeń otrzymywał szkolne imię. Ponadto musiał on mieć w swoim wyposażeniu tusz, kałamarz i pędzelek.

Wracając do roli nauczyciela, należy stwierdzić, że wtedy był on w szkole wszechwładnym panem. W przypadkach zaniedbań powstałych ze strony wychowanków, mógł stoso-

temat chińskiej kultury i literatury. Jest autorem pierwszego szeroko publikowanego słownika chińsko-angielskiego. Por. H.A. Giles, A Chinese-English dictionary, Shanghai 1912.

9 W.J. Sidichmienow, Chiny. Karty przeszłości, Warszawa 1978, s. 244-277 .

10 Kierując się zasadą filozofii konfucjanizmu należy zauważyć, że dziecko jako istota "niepełna” oraz "niekompletna”, tak szybko, jak to tylko było możliwe, miało być kształcone na różne sposoby, aby sprawnie przejść przez proces "transformacji” i stać się osobą „ukończoną”. Zob. Sellmann, Confucian ethics, op.cit., s. 13. 
wać wobec nich kary cielesne. Swoistym symbolem autorytetu i władzy nauczycielskiej była pałka wykonana z bambusa i umieszczona na stole nauczycielskim.

Dzieci wiejskie odbywały naukę równocześnie w jednej wspólnej klasie. Wiek uczniów wahał się od siedmiu do dwudziestu lat. Nie istniał jeden program nauczania. Każdy z wychowanków miał indywidualny kurs edukacji, który był uzależniony od stopnia zdolności wychowanka.

Nauka w szkole odbywała się w stały sposób: uczniowie najpierw przygotowali się samodzielnie, a potem byli kolejno sprawdzani i odpytywani z tego zadania, które wszyscy otrzymali od nauczyciela. W klasie panował hałas, gdyż chłopcy czytali i powtarzali na głos zadane teksty. Główną formą ich pracy było uczenie się na pamięć trudnych znaków pisma hieroglificznego oraz zapamiętywanie klasycznych ksiąg autorstwa Konfucjusza. W dawnej chińskiej szkole nie było książek do nauczania ani też nie istniały żadne pomoce dydaktyczne, które mogłyby uatrakcyjnić naukę i wzbudzić zainteresowanie wychowanków.

$\mathrm{Z}$ tego powodu uczeń musiał znać na pamięć wszystkie teksty podawane w szkole, chociaż często nie rozumiał ich treści. Przy odpowiedzi musiał odwrócić się plecami do tekstu i wyrecytować go z pamięci, bez zająknienia, stojąc przed nauczycielem. Nie było to rzeczą istotną czy rozumiał dany fragment, mógł nawet recytować bez zrozumienia, co było zgodne z ustanowionym prawem. Wspomniane wyżej księgi konfucjańskie, których uczniowie uczyli się na pamięć, miały pobudzić podopiecznych do poczucia miłości synowskiej, braterskiej dobroci, szacunku, wierności obowiązkom i pilności, a co najważniejsze - oddania cesarzowi. Uczniowie powinni byli przyjmować wypowiedzi dawnych mędrców jako aksjomaty i utrwalać je w pamięci. Wszelkie próby krytycznego podejścia chłopców do opanowanych tekstów były uznawane za podważanie ładu społecznego i za wnoszenie zamętu w świadomość własnego naro- 
du. Karano to surowo. Tego rodzaju system edukacji w szkołach chińskich trwał przez wieki.

Nauka kończyła się po siedmiu lub ośmiu latach uczęszczania do szkoły. W tym czasie uczeń mógł opanować około dwóch - trzech tysięcy znaków i zapamiętać najbardziej elementarne wiadomości z arytmetyki i historii Chin.

Jeśli rodzice posiadali odpowiednie warunki ekonomiczne, młody człowiek mógł kontynuować naukę w kolejnych szkołach: powiatowej i prowincjonalnej. Tam również uczył się ksiąg klasycznych z kanonu konfucjańskiego.

Ci uczniowie, którzy opanowali sztukę czytania i pisania oraz ci, którzy byli wykształceni, cieszyli się wielkim szacunkiem w oczach prostych ludzi. Byli bowiem uosobieniem mądrości Konfucjusza, a to pomagało im w karierze urzędniczej i było przyczyną bogacenia się.

Na mocy prawa do egzaminów mogli przystąpić pochodzący z wszelkich warstw społecznych, za wyjątkiem dzieci cyrulików. aktorów, nierządnic, właścicieli domów publicznych oraz sług.

Ci, którzy chcieli uzyskać stopień naukowy, musieli legitymować się świadectwem z poświadczeniem sąsiadów o nienagannej reputacji, niekaralności, wraz z zapewnieniem o stosownym pochodzeniu rodziny do trzech pokoleń wstecz.

Za panowania dynastii Qing egzaminy na stanowiska o charakterze urzędniczym dotyczyły głównie trzech typów: powiatowo-gminnych, prowincjonalnych i stołecznych ${ }^{11}$. Te pierwsze odbywały się w dwóch turach, najpierw w powiecie pod nadzorem naczelnika powiatu, a potem $\mathrm{w}$ gminie - pod kontrolą zarządcy gminy. Te osoby, które pomyślnie zdały oba egzaminy, otrzymywały tytuł uczniów, aby potem po zaliczeniu specjalnych egzaminów dostać pierwszy tytuł naukowy - sion-c’aj. Egzaminy te przeprowadzano uroczyście w przeznaczonych do

11 Por. Shang Yanliu, Qingdai keju kaoshi shulue [Summary of civil examinations during the Qing period], Beijing 1958. 
tego celu salach i pod nadzorem doświadczonych egzaminatorów. Ci młodzi, którzy uzyskali ten stopień w karierze naukowej, czynili kolejne przygotowania do egzaminów eliminacyjnych, aby zdobyć następne stopnie.

Egzaminy prowincjonalne przeprowadzano raz na trzy lata w centralnych miejscach prowincji. Mogli do nich przystąpić jedynie ci sion-c'aje, którzy wyróżniali się w nauce. Po tym etapie zdający pomyślnie otrzymywali drugi stopień naukowy - cu-żen.

Z kolei egzaminy stołeczne, które także odbywały się raz na trzy lata, były uprzednio sprawdzane, a ci, którzy je przeszli byli rejestrowani w Ministerstwie Ceremonii i dopuszczani do kolejnej tury egzaminacyjnej. Wreszcie jako ostatnie odbywały się egzaminy pałacowe, które były zdawane przed samym cesarzem $^{12}$. Po przejściu wszystkich etapów tego rodzaju edukacji urzędnik dostawał stopień cin-szy. Wówczas do Pekinu przyjeżdżało kilka tysięcy kandydatów, a jedynie trzystu otrzymywało ten zaszczytny tytuł członka Cesarskiej Akademii Nauk. Mogli oni być zaliczeni do grona pekińskiej Akademii Han-lin, którą ufundowano w 736 r. Tytuł akademika zaś uznawano za najwyższy na obszarze mandżurskich Chin. $\mathrm{Ci}$, którzy osiągnęli ten zaszczyt, mogli liczyć na najwyższe szczeble w hierarchii urzędniczej, dostać wysokie stanowisko oraz pozyskać tytuł „historyka pałacu cesarskiego".

Należy dodać, że w czasach dynastii Tang, poza wspomnianymi wyżej egzaminami urzędniczymi, nastąpił również przełom w szkolnictwie ${ }^{13}$. To wówczas wokół bibliotek i archiwów zaczęły tworzyć się prywatne akademie. Zakres ich kształcenia obejmował kanon konfucjański, filozofię, kaligrafię, nawet po-

12 Zob. Próg do kariery, [w:] Sławińska, H. Peijang, Chińszczyzna, op.cit., s. 40-48.

13 Por. B. Elman, A cultural history of civil examinations in late imperial China, Berkeley-Los Angeles 2000. 
ezję, ale także nauki praktyczne, jak np. prawo. Niestety, prywatnym akademiom brakowało ciągłości istnienia. Ponieważ brakowało im formy prawnej, szkoły te szybko upadały. Działały bowiem jedynie umownie.

Jedną z niewielu uczelni, które przetrwały jest Uniwersytet Hunański. Także wyżej wymieniona Akademia Han-lin przyjmowała wykształconych ludzi, którzy prowadzili tu prace badawcze i przygotowywali się do szerzej omówionych już powyżej egzaminów. Należy wspomnieć, że do Akademii uczonych zapraszał sam cesarz, a przynależność do tej jednostki była najwyższą nobilitacją dla chińskiego naukowca. Kształcono tu także ministrów, doradców cesarza, tłumaczy, tworzono encyklopedie i zbiory ${ }^{14}$. Akademia Han-lin przetrwała aż do 1905 r., w którym to została doszczętnie spalona.

\section{Nauczyciel}

Pierwszą wzmiankę o zawodzie nauczyciela - laoshi umieszczono w dawnym piśmiennictwie chińskim około 2200 lat p.n.e. Zawód ten ex definitione był ściśle powiązany z pracą dla państwa ${ }^{15}$. W hierarchii społecznej był określany jako ważny, chociaż generalnie pozycja nauczyciela była uzależniona od poziomu wykształcenia. Najwyższym szacunkiem w ówczesnym społeczeństwie cieszył się ten, kto pomyślnie zdał niezwykle trudny trójstopniowy egzamin państwowy. Egzaminacyjnej komisji krajowej przewodniczył sam cesarz.

14 Por. B. Elman, A. Woodside, Education E society in late imperial China, 1600-1900, Berkeley-Los Angeles 1994.

15 Termin $s h i$, który pierwotnie określał nauczyciela, wiąże się z odniesieniem do nazwy dowódcy dużej jednostki wojskowej, obejmującej 2500 żołnierzy. Dowódca ten, występujący jako mistrz w swoim fachu, mógł nauczać kolejne osoby jako shi zhang, czyli ktoś kto dowodzi dywizją i naucza podwładnych. Był zatem nauczycielem. 
Na przestrzeni dziejów w języku chińskim występowały różnorodne określenia dotyczące profesji nauczycielskiej. W historii Chin od VI w. p.n.e. występowali nauczyciele, którzy jako mistrzowie przekazywali swoją wiedzę zebranym wokół nich uczniom. Kolejni natomiast, będąc w kontakcie z rządzącymi i ich domami, bezpośrednio sami lub przy współudziale doradców, usiłowali przekazywać rady dotyczące zarządzania państwem i społeczeństwem. Odtąd aż do czasów współczesnych zawód nauczyciela cieszył się wielkim szacunkiem. W tradycji chińskiej można wskazać następującą hierarchię szacunku: jako najważniejsze wymienia się Niebiosa, a po nich występują Ziemia, Cesarz, rodzic i nauczyciel ${ }^{16}$. W dalszej kolejności idą dopiero inne zawody i funkcje społeczne.

Warto spostrzec, że wyżej wymienione typy relacji nauczyciela z uczniami nie odbiegają od znanego w kulturze europejskiej modelu edukacji uniwersyteckiej, jak i w kształceniu zawodowym. Tu również pojawiła się swoista relacja mistrza i uczniów. Jednakże można zauważyć ważną różnicę, która polegała na założeniu wszelkiej wiedzy wschodniego mistrza. Nie był on specjalistą w wąskiej dziedzinie wiedzy, ale miał stanowić wzorzec uniwersalny. Mógł bowiem służyć radą prawie w każdej życiowej kwestii.

\section{Terminy definiujące profesję nauczyciela}

Pani profesor Wu Lan podaje ${ }^{17}$, że odnośnie do zawodu nauczyciela najstarszym i najczęściej używanym terminem jest Xiansheng, co oznaczało nauczyciel, a już od starożytności pan. Za pierwszego i największego Xiansheng uznano znanego myśli-

16 Wg słów chińskiego historyka Sima Qian (ok. 145-86 r. p.n.e.) „ten, który uczył mnie przez jeden dzień, jest moim ojcem/mistrzem na całe życie”. Zob. Wu Lan, Nauczyciel w Chinach, op.cit., s. 208.

17 Ibidem, s. 208-209. 
ciela i pedagoga Konfucjusza (551-479 p.n.e.). W tym tytule zawiera się wielki szacunek oraz podziw dla ogromu wiedzy i wartości moralnych nauczyciela dawnej szkoły chińskiej. Jest to zgodne ze starożytną tradycją tego narodu. Na przestrzeni lat wyraz ten (xiansheng) ewoluował i przybierał nowe znaczenie, używane w różnym środowisku dla okazania szacunku społecznego względem osoby. W zakresie edukacji jest stosowany jako tytuł wobec tych, niezależnie od płci, których cechuje duże doświadczenie i właściwa postawa moralna.

Kolejny termin - to Laoshi, którym także określa się w Chinach wspomnianego już wyżej Konfucjusza jako „nauczyciela dla ludzi w każdym wieku". W tym miejscu warto odwołać się do okresu dynastii Tang ${ }^{18}$. Wówczas pisarz Han Yu (ur. 768 r. n. e. - zm. 824 r. n.e.) stwierdził, że: „nauczyciel to ten, który przekazuje wiedzę, uczy i wyjaśnia wątpliwości zwykłym ludziom"19. Termin Laoshi wskazuje na szacunek dla nauczyciela i jego poświęcenie dla nauki.

Następnym pojęciem związanym z zawodem nauczyciela będzie Ogrodnik. W Chinach bowiem nauczyciel był często porównywany do Ogrodnika, a jego wychowankowie - do sadzonek kwiatów i drzew, które trzeba mądrze podlewać, pielęgnować je i opiekować się nimi.

Szczególnie wzruszający wydaje się być termin Matka, który od wieków w Chinach jest używany także w odniesieniu do nauczyciela. Można tu wspomnieć dawne chińskie przysłowie, które podaje, że „Nauczyciel jest jak rodzic”, co stanowi odzwierciedlenie ogromnego uznania Chińczyków dla rzetelnej pracy nauczycielskiej. Rzeczownik Matka określa tych pedago-

18 Lata panowania: 18 czerwca 618-1 czerwca 907 r. n.e.

19 Han Yu, słynny poeta, publicysta i polityk, był jednym z prekursorów neokonfucjanizmu. W swoim traktacie O człowieku przekonywał, że człowiek stoi w jednym rzędzie ze wszystkimi istotami żywymi i że nie może znaleźć się ponad przyrodą. Zob. Encyklopedia historyczna świata, Starożytność, oprac. zbiorowe, t. III, Kraków 2000, s. 268. 
gów, którzy realizują się w swojej pracy, będąc pełnymi miłości i oddania dla uczniów, pasji, talentu i wiedzy.

Jako kolejny termin definiujący nauczycieli można wskazać Wiosenne jedwabniki ${ }^{20}$, które to określenie zastosowano w Księdze pieśni w 1097 r. p.n.e. Dla chińskiej społeczności jedwabniki są od zawsze symbolem poświęcenia, pewnej stałości oraz pokonywania trudów pracy w ciężkich warunkach. W odniesieniu do nauczycieli trzeba tu też mówić o zaangażowaniu i bezinteresownym nauczaniu podopiecznych.

Świeca - która pali się w milczeniu i oświetla bezinteresownie innych - to niezwykle sugestywne określenie nauczyciela, który będąc w służbie uczniom, swoją wiedzą oświetla im dalszą życiową wędrówkę.

W latach 722-481 p.n.e. na gruncie chińskim pojawiło się określenie Wót, które zostało użyte synonimicznie w odniesieniu do tych nauczycieli, których cechuje ciężka praca, nieoczekujących w zamian niczego szczególnego dla siebie. Termin ten niesie ze sobą pozytywne konotacje.

Także pozytywny wydźwięk zawiera się w kolejnym terminie Deszcz wiosenny, którym definiowano nauczycieli ożywiających zarówno serca, jak i umysły swoich wychowanków. Co więcej, stanowią oni inspirację do zdobywania wiedzy, pobudzania aktywności oraz do rozwoju w uczniach mądrości i szlachetności.

Ostatnim terminem, jaki tu zostanie podany, a odnoszącym się do nauczycieli, jest Drabina, co wśród nacji chińskiej jest najbardziej pozytywnym i chwalebnym określeniem tej profesji. Stanowi bowiem symbol stopniowego wspinania się uczniów po wiedzę zdobytą u właściwie wykształconych i stosownie przygotowanych do pracy nauczycieli.

20 Wu Lan, Nauczyciel w Chinach, op.cit., s. 210. 


\section{Materiały piśmiennicze}

Trzeba dodać, że społeczeństwo chińskie od wieków okazywało wielki szacunek tym, którzy poznali księgi klasyczne oraz posługiwali się pięknie zapisywanymi znakami. Niezwykle cennym materiałem był papier, a zapisaną już kartkę traktowano z szacunkiem. Jednakże należy wspomnieć, że początkowo Chińczycy zapisywali teksty na niewygodnych bambusowych i drewnianych deseczkach oraz na drogim materiale, jakim był jedwab. W 105 r. n.e. Chińczycy wykorzystali do pisania włókna kory drzewnej, pakuły, a także szmaty. Od X w., poza białym i żółtym, produkowano papier kolorowy, który nasączano olejem z cyprysów dla jego dłuższej żywotności. Jako narzędzi do pisania Chińczycy używali stożkowatych pędzelków, wykonanych z sierści zwierzęcej (owcy lub zająca), a także z ptasich piór, złączonych nićmi w pęczek i posmarowanych kalafonią. Dolna część pędzelka była często bogato zdobiona inkrustacją ze srebra i złota, drogich kamieni, kości słoniowej lub też z rogu nosorożca. Opakowaniem dla tego rodzaju narzędzi piśmienniczych był futerał. Chińczycy stosowali tusz nie tylko jako materiał piśmienniczy, ale i malarski oraz drukarski. Był on przyrządzany z sadzy, którą jako mieszaninę otrzymywano ze spalania oleju tungowego, rzepakowego i sezamowego oraz z kleju ze skór jeleni i krów. Dla uzyskania lepszej trwałości do tuszu dodawano białko z jajek, piżmo i zioła lecznicze. Tak spreparowaną mieszaninę wlewano do form, aby mieć tusz podzielony na kawałki.

Ważnym narzędziem był również kałamarz na tusz, o kształcie prostokątnej płytki, który pierwotnie był wykonany ze specjalnego kamienia. Posiadał także wgłębienia na wodę. Dla ochrony najlepszych kałamarzy stosowano futerały zrobione z drzewa sandałowego i gruszy. 


\section{Zakończenie}

Omówiony tu pokrótce system edukacyjny dawnych Chin wskazuje na tłumioną przez lata kreatywność podwładnych cesarza. Stworzył on bowiem urzędników, którzy nie byli w stanie przeciwstawić się autorytetowi władcy. Ponadto należy zauważyć, że system ten kontynuował także promowanie jednorodności kulturowej. Zamożne rodziny, zwłaszcza z klas najbogatszych, mogły zdecydowanie włączyć się do wspomnianego nauczania przez edukację swoich synów lub zakup kolejnych stopni w hierarchii awansu społecznego. Znawcy przedmiotowej literatury patrzą szczególnie krytycznie na XIX w., obwiniając przy tym ówczesny system imperialny ze względu na brak w Chinach wiedzy technicznej i porażkę w kolejnych starciach z obcymi mocarstwami.

\section{Bibliografia}

Elman B., A cultural history of civil examinations in late imperial China, Berkeley-Los Angeles 2000.

Elman B., Woodside A., Education E society in late imperial China, 1600-1900, Berkeley-Los Angeles 1994.

Encyklopedia historyczna świata, Starożytność, oprac. zbiorowe, t. III, Kraków 2000.

Giles H.A., A Chinese - English dictionary, Shanghai 1912.

Ross H.A., Education in China. Educational History. Models and initiatives, red. Q. Zha, Great Barrington 2013.

Sellmann J.D., Education in China. Educational History. Models and initiatives, red. Q. Zha, Great Barrington 2013.

Shang Yanliu, Qingdai keju kaoshi shulue [Summary of civil examinations during the Qing period], Beijing 1958. 
Sidichmienow W.J., Chiny. Karty przesztości, Warszawa 1978. Sławińska I., Peijang H., Chińszczyzna, Toruń 2004. Wu Lan, Z notatnika ttumacza literatury polskiej i chińskiej, Gdańsk 2019.

\begin{abstract}
Abstrakt
Artykuł dotyczy podstaw nauczania i wychowania w szkołach cesarskich Chin. Zawiera również informacje o klasycznych księgach konfucjańskich, które stanowiły bazę do przekazywania wiedzy o dawnych zasadach postępowania i administrowania państwem, o normach moralnych i obyczajowych, które były powszechnie stosowane w ówczesnym społeczeństwie. Ponadto pokazuje rolę, jaką na przestrzeni dziejów miał do odegrania nauczyciel w tamtejszym systemie edukacyjnym.
\end{abstract}

Słowa kluczowe: system nauczania i wychowania, szkoła, nauczyciel

\begin{abstract}
The article deals with the foundations of teaching and upbringing in the imperial schools of China. It also contains information about the classic Confucian books, which were the basis for the transfer of knowledge about the past rules of conduct and administration of the state, as well as about moral norms, widely used in contemporary society. In addition, it shows the role the teacher had to play throughout history in the local education system.
\end{abstract}

Keywords: teaching and upbringing system (education system), school, teacher 


\author{
Anna Gryszkiewicz \\ Uniwersytet Gdański \\ ORCID ID: https://orcid.org/0000-0003-2877-9303
}

\title{
Symbolika tańca w kole plemienia Amis podczas Święta Żniw w Yuli na Tajwanie - ujęcie postkolonialne
}

\section{Wstęp}

Dynamika relacji tajwańskich autochtonów z zewnętrznymi, najczęściej uprzywilejowanymi finansowo i społecznie podmiotami, przedstawiona jest w artykule za sprawą interpretacji symboliki rytuału tańca podczas jednego z najważniejszych i najliczniejszych świąt aborygeńskich w roku. Wiele przykładów, w tym badane przez Lee i Chang festiwale Ilisin i Pas-taai ${ }^{1}$, ukazują jak siłowe wykorzystanie dawnej kultury aborygeńskiej i eksploatowanie potencjału turystycznego miejsc zamieszkałych przez ludy tubylcze Tajwanu, które to ludy przez ostatnie dziesięciolecia uległy silnym procesom sinizacji, a w ciągu ostatnich pięciu wieków przejmowały język, rytuały i wierzenia kolejnych kolonizatorów i dominujących społeczności napływowych, prowadzi do estetycznych rozczarowań. Mimo wszystko widowiska te, cieszące się ogromną frekwencją i nieustającą popularnością wśród badaczy najróżniejszych dziedzin, od antropologów, etnologów, po historyków, teatrologów, psychologów społecz-

1 Lee Tsung Hung, Chang Pei-Shiang, Examining the Relationships among Festivalscape, Experiences, and Identity: Evidence from Two Taiwanese Aboriginal Festivals, „Leisure Studies” 2017, vol. 36, nr 4, s. 453-67. 
nych i politologów, dzięki swojej cykliczności i względnej powtarzalności są źródłem wiedzy konkurującej z hegemoniczną, wartościującą historiografią ${ }^{2}$, a tym samym dają niemały wgląd w hybrydyczność kulturową badanego regionu. Figura koła w tańcu staje się tu poniekąd miarą integracji i jednorodności tożsamościowej mieszkańców Tajwanu, jak również narzędziem transmisji dawnej kultury do współczesności.

\section{Kim oni są? Sprawczość spojrzenia, czyli tajwańscy autochtoni z perspektywy ludności napływowej}

Homi K. Bhabha tak rozpoczyna trzeci rozdział swojej książki Miejsca kultury:

„Istotną cechą dyskursu kolonialnego jest jego zależność od pojęcia »utrwalenia" « obecnego w ideologicznej konstrukcji inności. Utrwalenie jako znak różnicy kulturowej, historycznej lub rasowej w dyskursie kolonializmu jest stylem reprezentacji bazującym na pewnym paradoksie: przywołuje zarówno surowy i niezmienny porządek, jak i bezład, zwyrodnienie i demoniczność powtórzenia"3.

Ponieważ rdzenna ludność Tajwanu nie rozwinęła piśmiennych form językowych, transmisja pamięci grupowej i podstawowych wartości opierała się przede wszystkim na różnorodnych formach oralnych oraz praktykach cielesnych. Mity, piosenki i taniec stały się kluczowymi i rozpoznawalnymi elementami kultury aborygeńskiej ${ }^{4}$. Dzielenie się opowieściami, 2018.

2 E.W. Said, Orientalizm, tłum. M. Wyrwas-Wiśniewska, Warszawa

3 H.K. Bhabha, Miejsca kultury, tłum. T. Dobrogoszcz, Kraków 2010, s. 57.

4 Chao Chi-fang, "Holding Hands to Dance": Movement as Cultural Metaphor in the Dances of Indigenous People in Taiwan, [w:] Identity and Diversity: Celebrating Dance in Taiwan, red. Wang Yunyu, S. Burridge, New Delhi 2012, s. 2. 
wspólne tańce i śpiewanie, mimo iż były częścią codziennej rutyny, gwarantowały żywotność i aktualność tradycji. Ich znaczenie w budowaniu wspólnotowej tożsamości było fundamentalne przede wszystkim dlatego, że nie odbywały się na zasadzie diachronicznego układu obiekt - komentator, a na spontanicznym przekazie między uczestnikami, spośród których każdy mógł pełnić rolę przewodnika i każdy dysponował tą samą wiedzą. Do pojawienia się na wyspie Holendrów w 1624 r. ${ }^{5}$, kiedy rozpoczyna się dla Tajwanu trwający 364 lat i obejmujący kolejno sześć rządów imperialnych okres kolonializmu ${ }^{6}$, tradycje i praktyki codzienne z życia autochtonów opisywane były jedynie przez przybyłych podczas wypraw morskich Chińczyków Han. Wraz z holenderskimi protestantami na wyspę docierali zobowiązani do przyszłej pracy na rzecz kolonizatora mieszkańcy Chin kontynentalnych, głównie wychodźcy z prowincji położonych najbliżej wyspy, czyli Fujianu i Guangdongu (grupy etniczne Hoklo i Hakka) ${ }^{7}$, którzy stopniowo zasiedlali jej środkowo-południowy obszar. Na początku XVII w. północną część wyspy opanowali na prawie dwie dekady Hiszpanie, a wśród nich hiszpańscy misjonarze szerzący chrześcijaństwo. Dobrze zbudowani, przystosowani do życia w górach i wilgotnym klimacie oraz zaprawieni w łowiectwie autochtoni najczęściej odpowiadali atakami wobec nowo przybyłych Europejczyków. Współpraca z Holendrami szybko zakończyła się uznaniem za słuszną polityki agresji wobec aborygenów, co znacząco po-

5 J.B. Jacobs, P. Kang, Changing Taiwanese Identities, London-New York 2017, s. 1.

6 Opieram się na historycznej segmentacji dziejów Tajwanu wg J. Bruce’a Jacobsa. Do rządów kolonialistów na Tajwanie Jacobs zalicza: rządy Holendrów (1624-1662), Hiszpanów (1626-1642), reżim rodziny Zheng (1662-1683), rządy królestwa Manchu (1683-1895), rządy Japonii (1895-1945), rządy Chińskiej Partii Narodowej - Guomingdang (1945-1988).

7 R. Sławiński, Etnosy na Tajwanie, „Krakowskie Studia Międzynarodowe" 2011, nr 1, s. 89. 
mniejszyło ich populację ${ }^{8}$, na którą składało się wówczas około pięćdziesiąt grup etnolingwistycznych ${ }^{9}$. Jeszcze w okresie panowania dynastii Qing na Tajwanie, tamtejsze ludy tubylcze najczęściej uznawano za „dzikie” i nazywano „wschodnimi barbarzyńcami” (chin. 東番 dōngfān) lub „społecznością dzikich” (chin. 番社fänshè) ${ }^{10}$. Chao Chi-fang w swoich badaniach poddaje krytyce te najbardziej wartościujące i deprecjonujące opisy lokalnych rytuałów sporządzone przez przybyłych z kontynentu Hanów oraz misjonarzy chrześcijańskich zorientowanych na nawracanie „barbarzyńskich dusz”11.

Chrystianizacja i powolna sinizacja autochtonów w kolejnych stuleciach niosła ze sobą przynajmniej trzy skutki. Po pierwsze, tradycje i wierzenia grup etnicznych zaczęły się przenikać i hybrydyzować. Po drugie, ludność tubylcza stała się przedmiotem obserwacji dla ludności napływowej, która używając niejednorodnych standardów kulturowych i zróżnicowanych norm społecznych nierzadko stereotypizowała zachowania tubylców, a pamięć tychże utrwalała za pomocą pisma. Po trzecie, prawdopodobnie autochtoni w obliczu nowych podmiotów obserwujących i nieznanych dotąd sytuacji społecznych wywołanych konfrontacją z pierwszymi kolonizatorami, zaczęli, niczym za goffmanowską fasadą ${ }^{12}$, dramatyzować i manieryzować zachowania podczas rytuałów i świąt.

8 W tamtym czasie dzielono aborygenów na plemiona „równinne” (chin. 平埔族, píngpǔzú) oraz „wysokogórskie” (chin. 高山族, gāoshānzú), [w:] Baidu, hasto: gāoshānzú, https://baike.baidu.com/item/高山族 [dostęp: 13.02.2020].

9 S.A. Martin, Music, Marriage and Adaptation among the Bunun from Lost Laipunuk, Southern Taiwan (materiał z konferencji PSU Phuket International Conference), Phuket 2011, s. 1.

10 He Lanxi, 大国的疤痕 [Daguo de bahen], Pekin 2012.

11 Chao Chi-fang, "Holding..., op.cit., s. 5-6.

12 E. Goffman, Człowiek w teatrze życia codziennego, [w:] Antropologia widowisk: zagadnienia $i$ wybór tekstów, red. A. Chałupnik et al., Warszawa 2005, s. 47-60. 
Wydaje się, że właśnie wtedy, a nie jak pisze Madeline Kwok ${ }^{13}$, po anulowaniu traktatu z Shimoseki ${ }^{14}$ i dotarciu na Tajwan Chińskiej Partii Narodowej (Guomingdang), rozpoczął się proces teatralizacji tańców plemiennych na Tajwanie. Mimo że zgodnie z badaniami Kwok, dopiero po trwającej pół wieku kolonizacji Tajwanu przez Cesarstwo Japońskie i wkroczeniu Guomingdangu na wyspę, rozpoczęto budowę aborygeńskich centrów kultury, których widownię stanowiła społeczność nie-aborygeńska, to już pierwsze spotkania z kolonizatorami miały potencjał wytwarzania przesuniętych względem prawdy utrwaleń z życia rdzennej ludności.

Wracając do słów Bhabhy z początku podrozdziału, siłą dyskursu kolonialnego jest jego dwuznaczność, która polega na tym, że przedmiot tegoż dyskursu jest nie tylko „inny”, ale wzbudza jednocześnie uczucie pragnienia i obrzydzenia ${ }^{15}$. Fetyszyzacja przedmiotu działa niczym miecz obosieczny, oddaje część władzy w ręce przedmiotu i pozwala mu zakamuflować wiedzę na temat własnej, prawdziwej tożsamości. Bhabha, aby zdefiniować zachowanie się kolonizowanego względem kolonizatora, używa lacanowskiego pojęcia mimikry, której siła sprawia, że „wzrok nadzorujący powraca jako dokonujące przesunięcia spojrzenie nadzorowanych, w którym obserwator staje się obserwowanym, a «częściowe» przedstawienie reartykułuje całe pojęcie tożsamości i alienuje je z jego istoty"16. Podobnie, tajwańscy autochtoni w obliczu nowych fal migracji oraz dzia-

13 Ma. Kwok, Dance and Cultural Identity among the Paiwan Tribe of Pingtung County, Taiwan, „Dance Research Journal” 1978, vol. 11, nr 1/2, s. $35-40$.

14 Traktat pokojowy między Cesarstwem Chińskim i Cesarstwem Japońskim podpisano w Shimonoseki 17 kwietnia 1895 r., wśród jego postanowień znalazło się przekazanie Tajwanu wraz z przynależnymi mu wyspami Japonii. Traktat został anulowany w 1945 r.

15 H.K. Bhabha, Miejsca..., op.cit., s. 58.

16 Ibidem, s. 84. 
łań społecznych wdrażających wykorzystującą lokalny potencjał politykę imperialną, zmieniali, dopasowywali lub chronili - niczym za sprawą kamuflażu - własne dziedzictwo kulturowe. Liczba jego reprezentacji, która powstała na przestrzeni kilku ostatnich stuleci w odpowiedzi na intencjonalne i nacjonalistyczne poszukiwania znaczeń weń ukrytych jest zapewne ogromna, ale dostępność źródeł, która wynika ze wzmożonego zainteresowania kwestią tajwańskich mniejszości etnicznych w ostatnich, demokratycznych dekadach historii Tajwanu, każe mi ograniczyć się do znacznie krótszej perspektywy, jeśli chodzi o własne badania. W kolejnych podrozdziałach postaram się prześledzić zmiany, jakie zaszły w figurze rytualnego tańca w kole, zwracając uwagę na jej zaskakującą polimorficzność, będącą skutkiem politycznych, religijnych i społecznych wpływów od początku XX w.

\section{Tańce Amisów - pierwsze spojrzenie}

Figura koła podczas tańca, niezależnie od obszaru świata, z którego pochodzą tancerze, przywołuje bezpośrednie skojarzenia z jednością, solidarnością i wyższością znaczenia wspólnoty nad potrzebami jednostki. Według Ewy Nowickiej to właśnie „podczas tańca w kręgu tworzy się (...) turnerowska antystruktura, kiedy to fizyczna bliskość uczestników, identyczny ruch ciała, czasem też wspólny śpiew wywołują psychologiczne i społeczne zjawisko obejmowane przez turnerowskie pojęcie communitas $^{\prime 17}$. Kolisty układ tancerzy dotyczy najczęściej tańców związanych z festiwalami kulturowymi, świętami i uroczystościami rodzinnymi (plemiennymi), jak wesele lub pogrzeb. Jeśli mowa o tradycjach tanecznych tajwańskich autochtonów, figura tań-

17 E. Nowicka, Taniec $w$ kręgu: nowe $i$ dawne communitas, „Politeja” 2014, nr 31 (1), s. 217-242. 
ca kolistego zdominowała inne układy choreograficzne. Wśród szesnastu uznanych przez Radę ds. Aborygenów (chin. 原住民 族委員會, Yuánzhùmínzú wěiyuánhuì) plemion aborygeńskich ${ }^{18}$, Amisi, których tańce miałam okazję zobaczyć latem 2017 r., stanowią najliczniejszą grupę autochtonó $w^{19}$, a ich pieśni i rytuały są obecnie najlepiej zachowane i powszechnie rozpoznawalne. Obchodzone co roku Święto Żniw stanowi dla Amisów jedno z najważniejszych świąt plemiennych ${ }^{20}$. Współcześnie, ze względu na zainteresowanie mediów oraz wzmożoną aktywność Biura Turystyki Tajwanu, festiwal przyciąga setki turystów, w tym głównie ludność Han. Piszący o festiwalu dziennikarze często koncentrują się na podobieństwie Amisów do rdzennych Amerykanów, podając takie zbieżności, jak archaiczne tańce oraz zdobiące głowy pióropusze w przypadku obu mniejszości ${ }^{21}$.

W tradycji Amisów Święto Żniw miało na celu celebrację obfitych plonów, podziękowanie duszom przodków za czuwanie i opiekę, wyrażenie szacunku dla starszych pokoleń oraz nauczanie moralności i życia we wspólnocie najmłodszych członków klanu. Był to czas pojednania, radosnych tańców i wspólnych śpiewów. Ponieważ Amisi wierzą w życie pozagrobowe oraz uważają, że śmiertelnicy są w stanie zobaczyć swoich nieżyjących braci, Festiwal Zbiorów stał się doskonałą okazją do integracji ze światem umarłych. Tradycyjne tańce, podczas których uczestnicy łączyli się w kręgu i poruszali w rytm muzyki zgodnie

18 Council of Indigenous Peoples. Home Page, [原住民族委員會], https:// www.apc.gov.tw/portal/index.html?lang=en_US [dostęp: 13.02.2020].

19 Rada ds. Aborygenów poza Amisami uznaje plemiona: Atayal, Paiwan, Bunun, Puyuma, Rukai, Tsou, Saisiyat, Yami, Thao, Kavalan, Truku, Sakizaya, Seediq, Hla'alua, Kanakanavu.

20 L. Chiang, Kim Ling-chuan, The Amis Harvest Festival in Contemporary Taiwan, Hawaii 2003.

21 M. Rudolph, Ritual Performances as Authenticating Practices: Cultural Representations of Taiwan's Aborigines in Times of Political Change, „Performances” 2008, vol. 14. 
z ruchem wskazówek zegara, miały więc scalić społeczność żyjących i umarłych. W przeciwnym kierunku i osobnym kręgu mogli tańczyć jedynie mężczyźni, którym udało się upolować ofiarę (dawniej człowieka, później tylko zwierzynę) i przynieść do wioski jej głowę. Jak potwierdzają reprezentanci starszej generacji, polowanie na głowę ofiary było kiedyś integralną częścią tradycji plemiennej, sposobem na udowodnienie własnych umiejętności, prawości i zasadności równoprawnego bytowania w obliczu przodków. Tylko mężczyźni o tych cechach mogli uzyskać pełny tatuaż na twarzy, a tym samym wziąć ślub, płodzić potomstwo i powrócić do królestwa praojców po śmierci ${ }^{22}$. Taniec w kręgach miał więc znaczenie hierarchizujące i legitymujące podział społecznych przywilejów.

Metaforyka kręgu przywołuje także skojarzenie z samowolnym odizolowaniem się tancerzy od tego, co poza plemieniem. W tym sensie zamknięcie w figurze koła podkreślało intensyfikujący charakter wspólnej celebracji, podczas której wódz znajdujący się w centralnym punkcie wydarzenia był odpowiedzialny za zawiązywanie, z każdym rokiem na nowo, przymierza społecznego. Konsolidacja plemienna, jaka dokonywała się w figurze tańca, podkreślała jednocześnie odmienność wobec świata zewnętrznego i ograniczone zaufanie. Według Chiang i Kim początki Święta Zbóż sięgają czasów rywalizacji Amisów z silniejszym i legendarnie walecznym plemieniem Pisanaan. Festiwal miał wówczas trwać kilkanaście dni, czyli dostatecznie długo, aby móc wytrenować młodych mężczyzn do walki z wrogiem ${ }^{23}$. Krąg tańczących był zatem środowiskiem dla ćwiczeń fizycznych w gronie wzajemnie dopingujących się pobratymców. Zgodnie z tradycją ludową, zaangażowanie, dyscyplina oraz rzetelne przygotowanie fizyczne widoczne podczas

\footnotetext{
22 Ibidem, s. 105.

23 L. Chiang, Ling-chuan Kim, The Amis..., op.cit., s. 70.
} 
tańców, mogły gwarantować szczęście całej wsi w kolejnym roku.

Tańce pod gołym niebem wyrażały wreszcie radość z zakończonej powodzeniem pracy, miały charakter dziękczynny. Autochtoni dziękowali przodkom za opiekę i sprzyjające warunki pogodowe oraz przebłagiwali bóstwa i totemy, by chroniły ich dobytek, uprawy i zdrowie. W opisach europejskich misjonarzy z końca XIX w. tubylcy tańczą wokół ognia ${ }^{24}$, który w wierzeniach ludowych ma, poza wymiarem niszczycielskim, również wymiar oczyszczający i odradzający ${ }^{25}$. Amisi wierzyli, że jeśli któryś z członków klanu jest chory, wspólny taniec może go uzdrowić.

Dawne tańce nie uwzględniały obecności widowni, nikt nie mógł również dołączyć do tańczących, gdy taniec już się rozpoczął. Działo się tak na przykład podczas rytuału ofiarnego oddającego cześć przodkom, gdzie tańczący ani na moment nie mogli puścić ramion sąsiadujących partnerów. Oznaczałoby to bowiem wpuszczenie w zamknięty krąg złych duchów i rozplecenie więzów gwarantujących bezpieczeństwo grupy ${ }^{26}$.

\section{Tańce Amisów w obliczu sił imperialnych - reprezentacje}

Współcześnie Święta Żniw wyglądają inaczej niż kiedyś. Jak zostało wspomniane we wstępie, za umowny początek zmian prowadzących do konwersji rytuału plemiennego w zasilane obcym kapitałem potrzeb widowisko ${ }^{27}$ można uznać spotkanie autochtonów z kolonizatorami. W tej części artykułu postaram

24 Chao Chi-fang,nr 1/2,Holding..., op.cit., s. 6.

25 Zob. J.E. Cirlot, Stownik symboli, tłum. I. Kania, Kraków 2006.

26 Chao Chi-fang, "Holding..., op.cit., s. 11.

27 V. Turner, Od rytuału do teatru, tłum. M. Dziekan, J. Dziekan, Warszawa 2005. 
się nie tylko opisać nowe, zanikające i już zapomniane elementy obchodów festiwalowych (czerpiąc między innymi z doświadczeń własnego w nich uczestnictwa), ale również wyróżnić kilka czynników, które wpłynęły na nowy kształt festiwalu.

Chiang i Lin za jedną z ważniejszych przyczyn zmian wizerunkowych Święta Żniw podaje przedstawienie Tajwańczykom, w tym aborygenom, muzyki zachodniej w czasie, kiedy wyspa znajdowała się pod auspicjami Japonii (1895-1945). Według autorek właśnie pod wpływem Japończyków, którzy tłumaczyli oraz aplikowali na Tajwan muzykę z Zachodu, tradycyjne pieśni aborygenów zaczęły tracić swoje oryginalne brzmienie, które obejmowało wykorzystanie interwałów mikrotonowych i dźwięków o niedającej się określić jednoznacznie wysokości, swobodnego rytmu, wielokrotnego ornamentowania, niejednoznacznych centrów tonalnych oraz struktur wieloczęściowych ${ }^{28}$. Nowa muzyka rdzennej ludności przestała być wielogłosowa i niejednoznaczna, a stała się monofoniczna i odzwierciedlała fascynację kulturą Zachodu. Nieobojętne dla zmian w widowiskach aborygeńskich w tym czasie pozostają również pierwsze kontakty Tajwanu z zachodnią kulturą tańca odbywające się na zasadzie pośrednictwa Cesarstwa Japońskiego, którego jednym z podstawowych filarów polityki kolonialnej było zapewnienie nowoczesnej edukacji i osiągnięcie statusu hegemona kulturowego w rejonie Azja-Pacyfik ${ }^{29}$. W ten sposób kilka uzdolnionych studentek tańca wyjechało do Japonii w celach edukacyjnych, natomiast po powrocie na Tajwan założyły pierwsze prywatne studia taneczne. Od lat 60. rozpoczął się na dobre proces instytucjonalizacji działań tanecznych na Tajwanie, co również mogło wpłynąć na potrzebę wykorzystania ogromnego dziedzictwa kul-

28 L. Chiang, Kim Ling-chuan, The Amis..., op.cit., s. 20.

29 J.A. Tai, Modern Dance in Taiwan: A Brief Historical Review, s. 23, http://ir.lib.tut.edu.tw/wSite/PDFReader?xmlId=59558\&fileName $=1426$ 002661680\&format=pdf [dostęp: 13.02.2020]. 
turowego autochtonów dla celów rozrywkowych. Wartościowa w tym względzie jest uwaga Chiang i Lin o wydłużeniu Święta Żniw do miesiąca w okresie kolonii japońskiej. Decyzja wynikała z prozaicznej potrzeby odpowiednio długiego odpoczynku dla pracujących na wyspie oficjeli japońskich, dla których festiwal był świetnym pretekstem do zaangażowania się w zabawę i zapomnienia o codziennych obowiązkach.

Z kolei Madeline Kwok, badająca tożsamość kulturową plemienia Paiwan ${ }^{30}$, jest zdania, że dopiero po II wojnie światowej, podczas wzmożonej fali migracji z Chin kontynentalnych, tradycje taneczne autochtonów uległy najbardziej niszczycielskiej sile kolonializmu imperialnego. W latach 50 . XX w. elita polityczna i kulturowa, za jaką uważali się przedstawiciele Chińskiej Partii Narodowej, zaczęła wówczas budować centra kultury ludności autochtonicznej, gdzie „wskrzeszano” tubylcze rytuały, jednocześnie ujednolicając dotychczasową różnorodność stylistyczną tańców plemiennych. Można jedynie domyślać się jakie szkody wyrządziła ta odgórna syntetyzacja lokalnej kulturze. Kwok pisze, że w wyniku działań napływowej elity politycznej powstał nowy styl taneczny aborygenów, tzw. „styl ulepszony” (ang. improved style), który drastycznie różnił się od oryginalnych tańców autochtonów. Wśród różnic autorka wymienia te najdotkliwsze: „styl ulepszony” nie zważał na różnorodność stylistyczną wśród tradycji plemiennych, miał charakter syntetyzujący; był przepleciony elementami obcych kultur; tworzony w dużej mierze przez Hanów, nierzadko wykształconych w zachodnim stylu tanecznym, opierał się na domysłach i stereotypach dotyczących autochtonów; w reper-

30 Uważa się, że plemiona Puyuma, Ami, Paiwan i Rukai są ze sobą silnie spowinowacone, natomiast języki Ami i Paiwan należą do jednej grupy języków pajwańskich. Zob. E.K. Świętek, Tradycja i twórczość oralna tajwańskich aborygenów, „Maska. Magazyn Antropologiczno-Społeczno-Kulturowy" 2014, nr 23, s. 130-143. 
tuarze pojawiły się nowe piosenki, zdarzało się też, że wykonawcy śpiewali piosenki składające się z wymyślonych sylab, których brzmienie miało imitować języki plemienne; w stylu tym nie było miejsca na improwizację; pojawiły się nowe figury tanecznie, jak półokrąg, linie czy łuki; zlikwidowano żywy akompaniament wokalny; tańcom zaczęło towarzyszyć wcześniej nieobecne klaskanie; pojawiła się scena, a cała jej przestrzeń została zagospodarowana układami tanecznymi; usunięto podział na ważne i ważniejsze postaci tancerzy oraz na płeć $^{31}$. Ponieważ „styl ulepszony” zaczął obowiązywać w szkołach i centrach kultury, uczyli się go również młodzi aborygeni, nieznający własnych tradycji, po czasie uważając go za lepszy od tańców tradycyjnych.

Michael Rudolph w Ritual Performances as Authenticating Practices większość uwagi poświęca wpływowi chrześcijaństwa na widowiska rdzennej ludności Tajwanu. Po 1945 r. ogromna fala chrześcijańskich misjonarzy z Chin kontynentalnych zalała Tajwan. Próżnia religijna, która powstała po pięciu dekadach kolonii japońskiej, została szybko zapełniona przez dogmaty religii chrześcijańskiej. W latach 70. ponad 70\% aborygenów przeszło na protestantyzm lub katolicyzm ${ }^{32}$, a o wielu tradycjach autochtonów zapomniano aż do zniesienia stanu wojennego, kiedy młodzi intelektualiści i aktywiści zaangażowali się w ruch na rzecz rdzennej ludności. Rudolph zauważa, że za sprawą chrześcijaństwa podstawowa funkcja rytuału, który pozwalał komunikować się rdzennej ludności z przodkami i nawiązać więź duchową z częścią własnej, jednostkowej tożsamości, została usunięta. W ten sposób chrześcijaństwo spowodowało prawie całkowitą „desakralizację” społeczności autochtonicznej, a jej „zabobonne” rytuały zlikwidowano lub

\footnotetext{
31 M. Kwok, Dance and..., op.cit., s. 39-40.

32 M. Rudolph, Ritual Performances..., op.cit., s. 22.
} 
oczyszczono z „pogańskich” elementów ${ }^{33}$. Z centrum kręgów tanecznych zniknęli szamani i ich pomocnicy. Zastąpili ich reprezentanci Kościoła. Nie składano już krwawych ofiar ze zwierząt, a ceremonie skrócono z kilkunastu godzin do jednej lub dwóch.

Jak wspomniałam, po zniesieniu stanu wojennego w 1987 r., stosunek do rdzennej ludności zaczął powoli się zmieniać. Powstały ośrodki badawcze, których celem była ponowna identyfikacja kultury aborygenów. Jednocześnie, ze względu na powolną demokratyzację społeczeństwa tajwańskiego oraz otwarcie na gospodarki zachodnie, oczywistym stało się zagrożenie utraty dziedzictwa kulturowego autochtonów. Z jednej strony, idealiści i naukowcy poczuli potrzebę uwieczniania i rzeczywistego odtwarzania życia i rytuałów aborygeńskich, z drugiej, kolejne rządy tajwańskie zaczęły wykorzystywać kulturę mniejszości etnicznych dla wzmocnienia swoich własnych racji politycznych. Chociaż w 1999 r., dzięki podpisaniu dokumentu Nowego Partnerstwa Pomiędzy Rdzenną Ludnością a Rządem Tajwanu (chin. 原住民和台灣政府新的夥伴關係, Yuánzhùmín hé Táiwān zhèngfǔ xīn de huǒbàn guānxì), autochtonom zapewniono 8 miejsc w parlamencie, a w $2002 \mathrm{r}$. powołano Radę ds. Aborygenów ${ }^{34}$, na drodze do zachowania spuścizny kulturowej ludności stanęly kolejne wyzwania.

W Święcie Żniw plemienia Amis uczestniczyłam latem $2017 \mathrm{r}$. O festiwalu dowiedziałam się od tajwańskich przyjaciół, którzy z kolei przeczytali ogłoszenie na stronie internetowej biura miasteczka Yuli w prowincji Hualian ${ }^{35}$. Dotarliśmy na miejsce w samo

33 Ibidem, s. 96.

34 E.K. Świętek, Tradycja i twórczość oralna tajwańskich aborygenów, „Maska. Magazyn Antropologiczno-Społeczno-Kulturowy” 2014, s. 12.

35 'Huālián xiàn Yùlǐ zhèn gōngsuǒ - Yùlǐ zhīměi rénwén jǐngguān [花蓮 縣玉里鎮公所, 花蓮縣玉里鎮公所一玉里之美一人文景觀], https://www.hlyl.gov. tw/content_edit.php?menu=\&typeid=1266 [dostęp: 13.02.2020]. 
południe, w jeden z upalnych sierpniowych dni. Taksówkarz odwożący nas do gospodarstwa agroturystycznego otoczonego polami ryżowymi wskazał po drodze zieloną murawę z przygotowaną sceną, mówiąc, że wieczorem zbierze się tam tłum ludzi, i zaznaczając, że jest to jedna z wielu destynacji, gdzie odbędzie się festiwal, najprawdopodobniej największa, gdyż sponsorowana przez lokalny rząd. Wieczorem dookoła zielonego placu stanęły stoliki, przy których goście i uczestnicy zajadali przysmaki zakupione od sprzedawców handlujących po sąsiedzku i popijali lokalne wino z kaszy jaglanej (chin. 小米酒, xiăomǐjiǔ). W pasażu ze stoiskami tuż obok można było za drobną sumę tajwańskich dolarów „ustrzelić” maskotkę, wygrać los na loterii i kupić rękodzieło różnej maści w przesadnie jaskrawych kolorach. Na środku murawy stanęła wielka scena. Dudniący z głośników podkład muzyczny towarzyszył śpiewającym, których można było zobaczyć na jednym z dwóch dużych ekranów stanowiących tło sceny. Pośrodku, na podwyższeniu młode kobiety i mężczyźni, niczym trenerzy fitness, przewodzili reszcie tańczących. Mikroporty przypięte do pióropuszy niosły w przestrzeń kolejne polecenia: „W prawo!” „Wszyscy razem!”. Stroje uczestników były niekiedy wybrakowane, spódnice tańczących krótkie i odsłaniające zgrabne, umięśnione ciała. Część celebrujących ubrana była zwyczajnie i tańczyła w ostatnich kręgach, których, z uwagi na liczebność przybyłych, było przynajmniej trzy. Nad tłumem unosił się dron, z którego obraz wyświetlał się bezpośrednio na jednym z ekranów, na tyle ogromnych, że część spojrzeń tańczących lądowała właśnie na nich. Niewiele osób siedziało przy stolikach. Ludzie siadali właściwie tylko wtedy, kiedy kończyła się jedna piosenka i prowadzący zapraszał na scenę włodarzy miasta oraz czytał nazwiska i nazwy patronów festiwalu, dziękując co jakiś czas za dużą frekwencję. Mimo wyraźnie turystycznego charakteru wydarzenia, atmosfera radości i wspólnej celebracji była mocno wyczuwalna. 
Nie ma wątpliwości, że dostępność i popularność Święta Żniw zmieniła wizerunek festiwalu, który już w 2017 r. obejmował takie elementy, jak stoiska sprzedażowe i wystąpienia polityków. Nie dziwi też fakt, że autochtoni starają się wykorzystać potencjał świąt plemiennych do zarobku. Jest to tendencja widoczna we wszystkich społecznościach azjatyckich. Korzyści finansowe, jakie płyną z promocji regionu za sprawą upubliczniania dotychczas niedostępnych wydarzeń, są długotrwałe i pozwalają przetrwać w konkurencyjnym świecie współzawodnictwa gospodarczego i finansowego. Autentyczność rdzennej kultury schodzi w tym kontekście na drugi plan. Można więc uznać, że turyści stają się niszczycielską siłą na miarę takich kolonizatorów, jak Imperium Japońskie, Hanowie oraz chrześcijańscy misjonarze z Europy i Chin kontynentalnych. Kolonizatorów - turystów (w sensie zbiorowym), w przeciwieństwie do kolonizatorów - imperialistów czy kolonizatorów - misjonarzy, cechuje heterogeniczna i niejednorodna identyfikacja kulturowa. Ich potrzeby, realizowane na zasadzie usługa - pieniądz, są więc zaspokajane impulsywnie i intuicyjnie. Chaotyczny, naznaczony tymiż potrzebami produkt masowej turystyki, którym stały się w ostatnich latach festiwale aborygenów, jest pełen uproszczeń, przekłamań i stereotypów, tym większych, im większa różnorodność wiekowa i kulturowa panuje wśród przyjezdnych.

\section{Wnioski}

Podsumowując wpływ wymienionych czynników na współczesny wygląd festiwali aborygeńskich można wyciągnąć następujące wnioski. Po pierwsze, tradycje i wierzenia ludności autochtonicznej Tajwanu od czasów pierwszych kolonizatorów wyspy zmieniały swój kształt zależnie od sił imperialnych, 
w których władaniu ówcześnie znajdowała się wyspa. Po drugie, jeśli spojrzeć na ostatnie lata demokratycznych rządów Republiki Chińskiej, bez widocznego znaczenia dla zachowania kultury i tradycji autochtonów pozostaje fakt, że wiele instytucji politycznych i naukowych działa na rzecz praw rdzennej ludności. Wynika to bezpośrednio z globalnej tendencji wykorzystywania sektora kultury dla celów komercyjnych i łączenia go z sektorem usługowym. Po trzecie, masowa turystyka, globalizacja, urbanizacja terenów wiejskich i powszechny konsumpcjonizm mają siłę reorganizacji (czasem dewastacji) lokalnych tradycji porównywalną do wielkich imperiów i systemów religijnych. W tym sensie wymienione zjawiska wpisuja się we współczesny dyskurs kolonialny.

Tańce w kręgu, które miałam okazję zaobserwować w 2017 r., zyskały dziś nowe znaczenie. Wpuszczenie turysty w korowód taneczny symbolizuje proces dezintegracji zarówno kulturowej, jak i społecznej. Zamiana centralnie umiejscowionych uczestników rytuału na młodych, występujących na podwyższeniu i pilnujących choreograficznego porządku "trenerów”, wskazuje na nowy, finansowy cel takich spotkań, gdzie liczy się widoczny efekt i udana organizacja. Dyscyplina czasowa dyktowana przez odtwarzane na bieżąco nagrania muzyczne pokazuje brak spontaniczności rytuałów - w założeniu - duchowych, które kiedyś dopuszczały niesubordynację, chociażby w postaci tanecznego transu. Odejście od wyraźnych zasad dotyczących umiejscowienia starszych i młodszych oraz kobiet i dzieci w figurze tanecznej świadczy o dehierarchizacji społecznej i braku poszanowania dla przedstawicieli starszej generacji. Wreszcie, pojawienie się sceny obrazuje powolny zanik rytuału i pojawienie się widowiska, które wymusza określoną postawę aktorów względem odbiorców oraz dezorientuje uczestników w poczuciu prawdziwości wydarzenia. 


\section{Bibliografia}

Bhabha H.K., Miejsca kultury, tłum. T. Dobrogoszcz, Kraków 2010.

Chao Chi-fang, "Holding Hands to Dance": Movement as Cultural Metaphor in the Dances of Indigenous People in Taiwan, [w:] Identity and Diversity: Celebrating Dance in Taiwan, red. Wang Yunyu, S. Burridge, New Delhi 2012.

Chiang L., Kim Ling-chuan, The Amis Harvest Festival in Contemporary Taiwan, Hawaii 2003.

Cirlot J.E., Stownik symboli, tłum. I. Kania, Kraków 2006.

Council of Indigenous Peoples. Home Page, 原住民族委員會 [Yuanzhuminzu weiyuanhui], https://www.apc.gov.tw/portal/index.html?lang=en_US.

Goffman E., Człowiek w teatrze życia codziennego, [w:] Antropologia widowisk: zagadnienia $i$ wybór tekstów, red. A. Chałupnik et al., Warszawa 2005.

He Lanxi, 大国的疮痕 [Daguo de bahen], Pekin 2012.

Huālián xiàn Yùlî zhèn gōngsuǒ - Yùlǐ zhīměi rénwén jǔngguān [花蓮縣玉里鎮公所, 花蓮縣玉里鎮公所一玉里之美一人文景觀], https://www.hlyl.gov.tw/content_edit.php?menu=\&type$\mathrm{id}=1266$.

Jacobs J.B., Kang P., Changing Taiwanese Identities, London-New York 2017.

Kwok M., Dance and Cultural Identity among the Paiwan Tribe of Pingtung County, Taiwan, „Dance Research Journal” 1978, vol. 11, nr 1/2, t. 11.

Lee Tsung Hung, Chang Pei-Shiang, Examining the Relationships among Festivalscape, Experiences, and Identity: Evidence from Two Taiwanese Aboriginal Festivals, „Leisure Studies" 2017, vol. 36, nr 4.

Markowski M.P., Postkolonializm, [w:] Teorie literatury XX wieku. Podręcznik, red. A. Burzyńska, M.P. Markowski, Kraków 2007. 
Martin S.A., Music, Marriage and Adaptation among the Bunun from Lost Laipunuk, Southern Taiwan (materiał z konferencji PSU Phuket International Conference), Phuket 2011.

Nowicka E., Taniec w kręgu: nowe i dawne communitas, „Politeja" 2014, nr 31 (1).

Rudolph M., Ritual Performances as Authenticating Practices: Cultural Representations of Taiwan's Aborigines in Times of Political Change, „Performances” 2008, vol. 14.

Said E.W., Orientalizm, tłum. M. Wyrwas-Wiśniewska, Warszawa 2018.

Sławiński R., Etnosy na Tajwanie, „Krakowskie Studia Międzynarodowe" 2011, nr 1, s. 89-110.

Świętek E.K., Tradycja i twórczość oralna tajwańskich aborygenów, „Maska. Magazyn Antropologiczno-Społeczno-Kulturowy" 2014.

Tai J.A., Modern Dance in Taiwan: A Brief Historical Review, http://ir.lib.tut.edu.tw/wSite/PDFReader?xmlId=59558\&fileName $=1426002661680 \&$ format $=$ pdf.

Turner V., Od rytuatu do teatru, tłum. M. Dziekan, J. Dziekan, Warszawa 2005.

\begin{abstract}
Abstrakt
Materiał zebrany podczas badań terenowych na wyspie Tajwan w $2017 \mathrm{r}$. stał się głównym źródłem dla zawężonej analizy, której celem jest rozpoznanie symboliki figury koła $\mathrm{w}$ tańcu podczas obchodzonego na przełomie lipca i sierpnia przez ludność autochtoniczną Tajwanu Święta Żniw we wsi Yuli w prowincji Hualian. Doświadczenie uczestnictwa w obrzędzie celebrującym zakończone sukcesem zbieranie plonów oraz rozpoczęcie tym samym nowego roku upraw, pozwoliło mi zweryfikować dotychczasowe relacje uczestników wydarzeń o podobnym charakterze i spojrzeć na badany rytuał taneczny nie tylko z perspektywy historycznej, ale również uwzględniając jego współczesną odsłonę, w tym wymiar polityczny, ekonomiczny i społeczny. Jednocześnie, ponieważ
\end{abstract}


na historię Tajwanu składa się niezliczony ciąg podbojów i migracji fundowanych przez kolejne siły imperialne, zaproponowany przeze mnie dyskurs opiera się o metodologię badań postkolonialnych, gdzie pojęcie kulturowej dominacji obejmuje swym znaczeniem dysproporcje i „wielkie narracje" ${ }^{36}$ dyktowane przez różnorodne podmioty, od politycznych po religijne i komercyjne.

Słowa kluczowe: festiwale aborygenów, rdzenna ludność Tajwanu, plemię Amis, rytuały autochtonów, taniec na Tajwanie

\begin{abstract}
Notes and recordings collected during my stay in Taiwan in 2017 became the main source for deeper analysis, the purpose of which was to recognize the symbolism of the figure of dancing in circle during the Harvest Festival celebrated at the turn of July and August by the indigenous people of Taiwan in the village of Yuli in the province of Hualian. The experience of participating in this characteristic ritual celebrating successful harvesting and thus starting the new year, allowed me to verify the current reports of participants of similar events and look at this dance ritual not only from a historical perspective, but also taking into account its contemporary setting, including the political, economic and social dimension. Because Taiwan's history consists of countless conquests and migrations funded by successive imperial forces, the discourse I propose is based on the methodology of postcolonial research, where the concept of cultural domination includes disproportions and "great narratives" dictated by various entities, from political to religious and even commercial.
\end{abstract}

Keywords: aboriginal cultural festival, Taiwanese indigeonous people, Amis tribe, indigeonous rituals, dance in Taiwan

36 M.P. Markowski, Postkolonializm, [w:] Teorie literatury XX wieku. Podręcznik, red. A. Burzyńska, M.P. Markowski, Kraków 2007, s. 549-65. 


\section{Kornel Bielawski}

Uniwersytet Gdański

ORCID ID: https://orcid.org/0000-0002-4216-5714

\section{Indonezja po wyborach powszechnych w 2019 r.: w stronę rozwiązań nieliberalnych?}

Indonezja stanowi współcześnie jedno z najbardziej zróżnicowanych państw na świecie. Na przestrzeni dziejów jej usytuowanie geopolityczne oraz wyspiarski charakter stanowiły czynniki sprzyjające dywersyfikacji religijnej czy etnicznej. Choć współcześnie państwo to zaklasyfikować należy jako muzułmańskie, występują w nim mniejszości chrześcijańskie, buddyjskie, hinduistyczne, a także animistyczne, tworzące zróżnicowaną mozaikę społecznąa ${ }^{1}$.

W tak skomplikowanej konfiguracji społecznej procesy państwotwórcze wystawione były na wiele przeszkód. Wraz z kreowaniem wizji nowego, niepodległego państwa pokolonialnego różne grupy interesu zgłaszały swoje postulaty i projekty jego przyszłego kształtu. Tym samym, na przykład, sformułowano projekt tzw. Karty Jakarckiej czyniącej z Indonezji de facto państwo religijne. W owym czasie jednak dominująca grupa polityczna skłaniała się ku rozwiązaniom świeckim, opartym na nacjonalizmie jako spoiwie tworzącym państwo narodowe. Przyjęta w 1945 r. konstytucja, do której ostatecznie zapisy

1 Szacuje się, że muzułmanie stanowią $87,2 \%$ społeczeństwa indonezyjskiego. Do wyróżnionych mniejszości zaliczyć należy protestantów (7\%), katolików (2,9\%), hinduistów (1,7\%). Inne wyznania, w tym buddyzm i konfucjanizm $(0,9 \%)$. Więcej podstawowych danych statystycznych zob. The World Factbook, https://www.cia.gov/library/publications/the-world-factbook/geos/id.html [dostęp: 17.09.2019]. 
Karty Jakarckiej nie trafiły, a której podstawą była Pancasila, gwarantowała wolność wyznania każdego obywatela ${ }^{2}$.

Choć od końca lat 40. XX w. sytuacja polityczna Indonezji daleka była od standardów, które można by uznać za demokratyczne (za przykład posłużyć może decyzja o przejściu do „demokracji kierowanej" przez Sukarno czy okres ponadtrzydziestoletnich autorytarnych rządów prezydenta Suharto), czynnik religijny nie zdominował procesów politycznych państwa. Doniosłe zmiany w tym względzie przyniósł 1998 r., gdy w wyniku gwałtownego oporu społecznego i wewnętrznego pęknięcia wśród bliskich Suharto elit politycznych ${ }^{3}$, rządzący prezydent ogłosił ustąpienie ze stanowiska. Rozpoczęty proces demokratyzacji państwa (reformasi), trudny i powolny (zwraca się uwagę na nieefektywność, a niekiedy i bierność następujących po rządzącym krótko B.J. Habibie prezydentów Wahida i Sukarnoputri ${ }^{4}$ ) ujawnił wiele „zamrożonych” dotychczas problemów. Wraz z upadkiem Suharto bowiem ponownie zaczęto stawiać pytania o przyszły kształt i charakter państwa. Nieprzygotowane na tak nagłą zmianę systemową społeczeństwo zaczęło dzielić się wzdłuż podziałów religijnych, napędzane wzajemną nieufnością i strachem przed utratą przywilejów, dotychczasowej pozycji społecznej i politycznej czy antagonizmem innych grup wyznaniowych stawiających coraz agresywniejsze żądania. Wyrazem tych napięć były na przykład konflikty religijne, które na przełomie wieków wybuchły między chrześcijanami a muzułmanami na Molukach i Sulawesi (Poso) ${ }^{5}$.

2 N. Laskowska, Indonezja, Warszawa 2012, s. 69.

3 Y. Fukuoka, Debating Indonesia's Reformasi: Bridging "Parallel Universes”, „Journal of Contemporary Asia” 2014, vol. 44, nr 3, s. 541.

4 E. Aspinall, Semi-Opponents in Power: The Abdurrahman Wahid and Megawati Soekarnoputri Presidencies, [w:] Soeharto's New Order and Its Legacy, red. E. Aspinall, G. Fealy, Canberra 2010, s. 126.

5 Na temat tych konfliktów religijnych zob.: A. Rabasa, J. Haseman, The Military and Democracy in Indonesia. Challenges, Politics, and Power, 
Wstępujący na stanowisko prezydenta w 2004 r. Susilo Bambang Yudhoyono, generał i polityczny beneficjent wspomnianych konfliktów, zdawał się być remedium na zażegnanie kryzysów i wyprowadzenie indonezyjskiej demokracji na prostą. Nie oznaczało to, oczywiście, nagłego wypracowania demokratycznych standardów w rozumieniu zachodnim. Dynamicznie rozwijające się społeczeństwo indonezyjskie podlegało różnorakim procesom zmian i ujawniającym się podmiotom politycznym. Na przestrzeni dwóch minionych dekad dało się zauważyć oddolną działalność organizacji pozarządowycho charakterze religijnym. Szczególną uwagę zwracają organizacje Hizbut Tahrir Indonesia (zdelegalizowana w 2017 r. z powodu otwartego odrzucania podstawy ideologicznej Indonezji - Pancasili ${ }^{6}$ ) czy Front Obrońców Islamu (Front Pembela Islam, FPI) stale odgrywający istotną rolę w mobilizacji społecznej konserwatywnych muzułmanów. W przeciwieństwie do licznych zmian społecznych i towarzyszącej im dynamiki, elity polityczne zdawały się być niezmienne, głęboko zakorzenione w strukturach władzy i wysoce skorumpowane.

Wybory prezydenckie w 2014 r. określane były jako przełomowe. Wybór, którego mieli dokonać Indonezyjczycy wówczas prezentował się następująco: prezydentem zostanie przedstawiciel starego systemu, były zięć prezydenta Suharto, generał Prabowo Subianto, obciążony podejrzeniami choćby w zakresie łamania praw człowieka i brutalnych działań wobec protestujących w 1998 r. i skłaniający się ku rozwiązaniom nieliberal-

Santa Monica 2002; J. Bertrand, Legacies of the Authoritarian Past: Religious Violence in Indonesia's Moluccan Islands, „Pacific Affairs” 2002, vol. 75, nr 1; A. Sangaji, The security forces and regional violence in Poso, [w:] Renegotiating Boundaries. Local Politics in Post-Suharto Indonesia, red. H.S. Nordholt, G. van Klinken, Leiden 2007.

6 D.A. Sinaga, A. Almanar, N. Setuningsih, Gov't Officially Disbands Hizbut Tahrir Indonesia, Jakarta Globe, https://jakartaglobe.id/context/ govt-officially-disbands-hizbut-tahrir-indonesia [dostęp: 17.09.2019]. 
nym, coraz mocniej wiążący się politycznie z radykalnymi środowiskami muzułmańskimi, natomiast drugi wybór stanowił Joko Widodo (Jokowi), którego wizerunek kojarzony był z postępem demokratyzacji oraz zdecydowaną wrogością wobec powszechnej w Indonezji korupcji (w istocie wywodził się on spoza establishmentu, co nadawało mu pewnej wiarygodności w tym zakresie). Joko Widodo wygrał wybory niewielką różnicą głosów (6,3\%), co dowodziło istnienia wyraźnego podziału społecznego ${ }^{7}$. Szczególnie w tym aspekcie dawały o sobie znać kwestie pochodzenia i wyznania. Już wówczas w kampanii wyborczej dochodziło do mobilizacji społeczeństwa na podstawie tożsamości. Konserwatywni muzułmanie popierali Prabowo Subianto; umiarkowani zaś, a także mniejszości religijne, popierały Joko Widodo.

Prezydentura Widodo dla wielu okazała się rozczarowaniem. Po dwóch latach względnej bierności, udało mu się skonsolidować władzę i stworzyć stabilną koalicję polityczną. Obserwatorzy oceniają, że pierwsza kadencja Widodo nie przyniosła znaczących zmian w zakresie jakości demokratycznych w państwie. Zauważalna jest za to dynamika rozwoju ekonomicznego oraz infrastrukturalnego. Joko Widodo bowiem traktuje rozwój priorytetowo, a wszelkie zagadnienia o charakterze nieekonomicznym uznaje za drugorzędne lub służące nadrzędnemu celowi. Efektywne zarządzenie wydaje się dla prezydenta Indonezji kluczowe w celu kreowania wizerunku dobrego, sprawnego zarządcy. By to osiągnąć Jokowi chce szybkich i odważnych decyzji - te jednak nie idą w parze $\mathrm{z}$ charakterem procesu decyzyjnego, opartego na procedurach i transparentności. Wskazuje się, że Joko Widodo nie ma cierpliwości wobec takich procedur i złożoności prawnych i cechuje się raczej tendencjami do po-

7 E. Aspinall, M. Mietzner, Indonesian Politics in 2014: Democracy's Close Call, „Bulletin of Indonesian Economic Studies” 2014, vol. 50, nr 3, s. 347-369. 
dejmowania władczych decyzji, często ad hoc, w zależności od wymogów sytuacji ${ }^{8}$.

Jednak szczególnie alarmujące powinny być działania Joko Widodo względem opozycji. Po pierwsze, w 2014 r. na stanowisko prokuratora generalnego, dotychczas tradycyjnie apolitycznego, mianował swojego koalicjanta, polityka Muhammada Prasetyo, który bardzo szybko zaczął przygotowywać i wydawać akty oskarżenia (przeważnie dotyczące korupcji) wobec przeciwników politycznych, którzy, by uniknąć oskarżeń i procesu, decydowali się poprzeć Jokowiego w parlamencie i przystąpić do tworzonej przezeń koalicji. Jednocześnie Prasetyo uchodzi za zdecydowanego zwolennika kary śmierci, wciąż obowiązującej w Indonezji np. za przemyt narkotyków ${ }^{9}$.

Po drugie, zwraca się uwagę na popularne w mediach społecznościowych hasło \#2019GantiPresiden lub 2019GP, co oznacza „w 2019 zmień prezydenta”. Hasło to mieści się w ramach demokratycznego, pokojowego, zgodnego z prawem sprzeciwu. Slogan ten okazał się na tyle popularny, że przynosił zyski komercyjne - w sklepach dostępne były koszulki ze wspomnianym napisem ${ }^{10}$. Jokowi ocenił je jako zagrożenie na tyle wysokie, by uznać za zasadną mobilizację policji rekwirującej towary i zatrzymującej sklepowych sprzedawców ${ }^{11}$.

8 E. Warburton, Jokowi and the New Developmentalism, „Bulletin of Indonesian Economic Studies" 2016, vol. 52, nr 3, s. 297-320.

9 Attorney General Muhammad Prasetyo: Don't Test My Resolve!, Tempo, https://en.tempo.co/read/643562/attorney-general-muhammad-prasetyo-dont-test-my-resolve [dostęp: 12.09.2019].

10 Manifestacja poglądów politycznych na ubiorze wydaje się stawać w Indonezji codziennością. Nie tylko hasła antyprezydenckie cieszą się popularnością, ale również te wyrażające nostalgię za rządami prezydenta Suharto, które kojarzone były ze względnym bezpieczeństwem ekonomicznym.

11 T. Power, Jokowi's authoritarian turn, New Mandala, https://www. newmandala.org/jokowis-authoritarian-turn/ [dostęp: 12.09.2019]. 
O sile podziałów społecznych i znaczeniu polityki tożsamości w Indonezji świadczą także wydarzenia związane z kampanią wyborczą i wyborami gubernatorskimi w Jakarcie w 2017 r. Pełniący dotychczas tę funkcję Basuki Tjahaja Purnama (Ahok), bliski współpracownik Joko Widodo, a w latach 2012-2014 zastępca gubernatora rywalizował z dwoma głównymi kandydatami: Aniesem Baswedanem, popieranym przez Gerindrę Prabowo Subianto oraz Agusem Yudhoyono, rezygnującym z kariery wojskowej na rzecz próby utworzenia czegoś na wzór dynastii politycznej. Yudhoyono został wyeliminowany w pierwszej turze, a główna rywalizacja obu pozostałych w drugiej turze kandydatów opierała się na silnych podziałach społecznych.

Ahok, co okazało się znamienne, nie tylko nie jest muzułmaninem, ale także ma chińskie pochodzenie. Oponenci polityczni mobilizowali zatem przeciwko niemu rzesze konserwatywnych muzułmanów powtarzających, że muzułmanami nie może rządzić innowierca. Pochodzenie etniczne również pozostaje nie bez znaczenia: na przestrzeni dziejów Indonezji Chińczycy budzili raczej negatywne reakcje: oskarża się ich m.in. o kontrolę bogactwa narodowego, a tym samym o występowanie znaczących nierówności społecznych. Sam gubernator przez dwa lata zarządzania stolicą swoim twardym, uznawanym za niepolityczny językiem zniechęcił do siebie nie tylko muzułmanów, ale także najuboższy segment społeczny (wynikało to z przymusowych przesiedleń i tworzenia miejsc pod nowe inwestycje) czy innych Indonezyjczyków pochodzenia chińskiego (w tym przypadku pojawiały się obawy, że bezkompromisowość Ahoka ściągnie na nich gniew reszty społeczeństwa wzorem wydarzeń z 1998 r.). Krytycznym jednak wydarzeniem było przywołanie przez Ahoka, w trakcie wyborczego przemówienia, wersetów Koranu mówiących właśnie o tym, że muzułmanie nie mogą mieć nad sobą innowiercy. Ahok podważył to twierdzenie, co wywołało lawinowe, masowe protesty w Jakarcie. Za ich orga- 
nizację i przebieg w znacznej mierze odpowiadało FPI, którego lider, Habib Rizieq Shihab, purytański uczony, oskarżany jest, jak na ironię, o złamanie prawa antypornograficznego ${ }^{12}$.

Ahok ostatecznie wybory przegrał, a ponadto został skazany na dwa lata pozbawienia wolności za bluźnierstwo. Był to jeden z najwyraźniejszych, choć nie jedyny, przypadków zastosowania prawa o bluźnierstwie jako skutecznej broni konserwatywnych muzułmanów przeciw innym oponentom politycznym.

Prawo o bluźnierstwie wdrożone zostało w 1965 r. Zakazuje ono głoszenia tez naruszających powszechnie przyjęte nauczanie religijne ${ }^{13}$. Tym samym ogranicza ono wolność wyznania grup uznanych za sekciarskie. Jednocześnie zachęca ono do bezpośrednich działań pozaprawnych podejmowanych przez samych konserwatystów. Tak na przykład było z atakami na członków ruchu religijnego Ahmadijja, gdzie nie tylko dochodziło do aktów przemocy fizycznej, ale również nawoływano do likwidacji członków tego ruchu ${ }^{14}$.

Innym przykładem jest kara 18 miesięcy więzienia dla buddystki mieszkającej w Północnej Sumatrze. Poprosiła ona o ściszenie głośników zamontowanych na pobliskim meczecie. Wyrok skazujący w tej sprawie dowodzi znaczących nierówności prawnych w zależności od wyznania. Stanowi też kolejną zachę-

12 Zob. szerz.: K. Bielawski, Wybory gubernatorskie w Jakarcie w 2017 roku a problem radykalizmu, [w:] Systemy polityczne i kultura prawna państw azjatyckich, red. J. Marszałek-Kawa, M. Bidziński, Torun 2018.

13 N. Hasan, Religious Diversity and Blasphemy Law. Understanding Growing Religious Conflict and Intolerance in Post-Suharto Indonesia, „AlJāmi'ah: Journal of Islamic Studies” 2017, vol. 55, nr 1, s. 108.

14 Zob. szerz.: M. Crouch, Indonesia, Militant Islam and Ahmadiyah: Origins and Implications, ARC Federation Fellowship, „Islam, Shariah and Governance' Background Paper Series” 2009, nr 4; V. Arianti, T.R. Mostarom, Managing Religious Tensions: Indonesia's Current Dilemma, „Counter Terrorist Trends and Analyses" 2011, vol. 3, nr 3, s. 4; S. Yuniarni, Why Are Ahmadiyah Followers in Indonesia Attacked?, Jakarta Globe, https:// jakartaglobe.id/context/ahmadiyah-followers-indonesia-attacked/ [dostęp: 12.08.2019]. 
tę dla radykałów do dalszego forsowania swoich postulatów. Stawia to też znak zapytania nad dalszym losem wolności religijnej w Indonezji, a zarazem bezpieczeństwa nie tylko mniejszości religijnych, ale też grup z jakiegoś powodu potępianych w dyskursie radykałów, np. mniejszości seksualnych ${ }^{15}$.

Umiarkowanie religijne prezydenta Widodo, jeszcze w trakcie trwania pierwszej kadencji, nie oznaczało twardego sprzeciwu wobec stosowanych praktyk. Jokowi nie stanął w obronie Ahoka ani nie występował znacząco przeciw radykałom, gdyż miał przed sobą walkę o drugą kadencję i zdawał sobie sprawę, że instrument użyty przeciw byłemu współpracownikowi może zostać wykorzystany także przeciwko niemu. Tak też w istocie było - w przestrzeni publicznej, szczególnie w Internecie wielokrotnie pojawiały się informacje uderzające w prezydenta: sugerowano, że nie jest on tak naprawdę muzułmaninem, że ma chińskie korzenie, że jest zagranicznym agentem, a w młodości nawet był satanistą (na potwierdzenie tego opublikowano zdjęcie młodego Widodo, ubranego w skórzaną kurtkę i mającego nietypową, „buntowniczą” fryzurę) $)^{16}$.

15 K. Bielawski, Szariat a prawa człowieka w Acehu, „Cywilizacja i Polityka” 2015, nr 13.

16 Problem „fake newsów” istotnie wpływa na debatę publiczną w Indonezji. Wskazuje się, że wciąż 6\% społeczeństwa wierzy, że Joko Widodo jest członkiem zdelegalizowanej Komunistycznej Partii Indonezji. Społeczeństwo indonezyjskie przejawia tendencje do nieufności wobec mediów mainstreamowych, skłaniając się raczej do plotek i „poufnych” wiadomości przesyłanych przez komunikator na Facebooku czy WhatsAppa. Zob. szerz.: President Jokowi Clarifies Fake News Circulated in Social Media, Cabinet Secretariat of The Republic of Indonesia, https://setkab.go.id/en/ president-jokowi-clarifies-fake-news-circulated-in-social-media/ [dostęp: 10.09.2019]; President Jokowi: Don't Trust Fake News, Hoaxes on Social Media, Cabinet Secretariat of The Republic of Indonesia, https://setkab. go.id/en/president-jokowi-dont-trust-fake-news-hoaxes-on-social-media/ [dostęp: 10.09.2019]; K. Lamb, Fake news spikes in Indonesia ahead of elections, https://www.theguardian.com/world/2019/mar/20/fake-news-spikesin-indonesia-ahead-of-elections [dostęp: 10.09.2019]; A. Renaldi, Indonesia's 2019 Election Is Keeping Fake News Fact Checkers Way Too Busy, Vice, 
Joko Widodo, jako główny cel spreparowanych wiadomości, zmuszony był do podjęcia działań neutralizujących to społecznie szkodliwe zjawisko. Należy jednak zwrócić uwagę, że choć w oficjalnym dyskursie Jokowi potępia takie praktyki, w okresie przedwyborczym działała także grupa oczerniająca Prabowo Subianto. Wspomniana wcześniej skłonność Indonezyjczyków do dawania wiary fałszywym wiadomościom została skapitalizowana przez obie strony wyścigu prezydenckiego ${ }^{17}$.

Jednocześnie Jokowi musiał zaoferować coś umiarkowanym i świeckim wyborcom. Aby zneutralizować, a przynajmniej zminimalizować negatywny odbiór przez konserwatystów, kandydatem na wiceprezydenta został Ma’aruf Amin, konserwatywny uczony, dotychczasowy przewodniczący Indonezyjskiej Rady Ulemów czy przywódca Nahdlatul Ulama. Delegalizacja FPI, wzorem losu HTI, wydaje się niemożliwa ze względu na zbyt dużą popularność tego ruchu i ryzyko zorganizowania masowych protestów na wzór tych odbywających się przeciw Ahokowi na przełomie lat 2016 i 2017. Można podejrzewać, że korzystniejsze z politycznego punktu widzenia byłoby przyjęcie postawy nieprowokującej i łagodzącej postawy konserwatystów.

https://www.vice.com/en_asia/article/59v43d/indonesia-fake-news-presidential-election-jokowi-prabowo-hoax-season [dostęp: 9.09.2019].

17 D. Lipson, Indonesia's 'buzzers' paid to spread propaganda as political elite wage war ahead of election, ABC, https://www.abc.net.au/news/201808-13/indonesian-buzzers-paid-to-spread-propaganda-ahead-of-election/9928870 [dostęp: 11.09.2019]; F. Potkin, A.B. Da Costa, In Indonesia, Facebook and Twitter are 'buzzer' battlegrounds as elections loom, Reuters, https://www.reuters.com/article/us-indonesia-election-socialmedia-insigh/in-indonesia-facebook-and-twitter-are-buzzer-battlegrounds-as-elections-loom-idUSKBN1QU0AS [dostęp: 11.09.2019]; K. Lamb, 'I felt disgusted': inside Indonesia's fake Twitter account factories, „The Guardian”, https:// www.theguardian.com/world/2018/jul/23/indonesias-fake-twitter-account-factories-jakarta-politic [dostęp: 12.09.2019]; R. Perper, Social media 'buzzers' are being paid by Indonesian political parties to spread propaganda ahead of local elections, Business Insider Australia, https://www.businessinsider.com.au/indonesia-election-buzzers-election-propaganda-2018-8 [dostęp: 12.09.2019]. 
Dlatego też w serii debat transmitowanych w telewizji w trakcie kampanii przed wyborami w 2019 r. żaden z dwóch kandydatów nie odnosił się zbyt gorliwie do problemu praw człowieka i wolności wyznania. Świadczy to o ogromnej sile społecznej i politycznej środowisk radykalnych.

Wybory powszechne, które odbyły się w kwietniu 2019 r. były jednymi z najbardziej skomplikowanych przedsięwzięć na świecie. Wybory prezydenckie połączone były z wyborami parlamentarnymi i lokalnymi, w których w sumie o 20 tys. mandatów ubiegało się 245 tys. kandydatów. Joko Widodo został wybrany na drugą kadencję 55,5\% głosów, pokonując Prabowo Subianto z 44,5\% poparcia. Sposób rozłożenia głosów na obu kandydatów w poszczególnych prowincjach dowodzi wspomnianych wcześniej aspektów tożsamościowych. Tym samym np. Prabowo Subianto wygrał w prowincjach cechujących się większą ortodoksyjnością religijną (szczególnie Aceh), Jokowi natomiast popierany był przez muzułmanów umiarkowanych, chrześcijan, a także hinduistów na Bali. Wyniki na przeludnionej Jawie, szczególnie ważnej z wyborczego punktu widzenia, również potwierdzają tezę o istocie tożsamości: Jawa Środkowa i Wschodnia poparła obecnego prezydenta (znaczenie miał czynnik etniczny, gdzie zdecydowaną większość stanowią Jawajczycy). Natomiast na Jawie Zachodniej, gdzie Jawajczycy nie stanowią większości, Jokowi otrzymał o wiele mniej głosów ${ }^{18}$.

Druga i zarazem ostatnia kadencja prezydentury Joko Widodo będzie kluczowa dla stanu demokracji w Indonezji. Jokowi będzie miał okazję odnieść się do pilnych problemów społecznych i zależnie od decyzji przyczynić się do powstrzymania radykalnych, nieliberalnych ruchów religijnych albo przeciw-

18 Szczegółowe wykresy i analiza wyników w poszczególnych prowincjach: T. Pepinsky, Religion, ethnicity, and Indonesia's 2019 presidential election, New Mandala, https://www.newmandala.org/religion-ethnicity-and-indonesias-2019-presidential-election/ [dostęp: 13.09.2019]. 
nie, do ich rozkwitu. Indonezja tym samym zdaje się być na rozdrożu. Ostatnia kadencja powinna sprzyjać odważniejszym decyzjom politycznym prezydenta, który w lipcu zapowiedział dążenia do zwiększenia efektywności aparatu państwowego. Być może stworzy to okazję do zajęcia się jednym z najtrudniejszych problemów, jakim jest nierozwiązana kwestia masakr dokonanych w latach 1965-1966, co stanowiło wszakże element jego kampanii wyborczej pięć lat wcześniej. Do dziś ofiary i ich rodziny nie doczekały się sprawiedliwości, a sprawcy nigdy nie zostali pociągnięci do odpowiedzialności. Pomimo ponad pięćdziesięciu lat, które upłynęły od tych wydarzeń, temat ten stale wykorzystywany jest politycznie jako element zarządzania społecznym strachem, a podjęcie go stanowić może rodzaj politycznego samobójstwa ${ }^{19}$.

Oczywiście nie bez znaczenia pozostanie sposób, w jaki Jokowi będzie podejmował ewentualne działania. Wspomniane wcześniej tendencje do autorytarnego sprawowania rządów grożą utrwaleniem takiej metodyki w zakresie funkcjonowania kluczowych instytucji państwa. Jeżeli Jokowi faktycznie chce przyczynić się do wzmocnienia mechanizmów demokratycznych w Indonezji, musi zacząć od siebie samego, od przestrzegania przepisów i odejścia od decyzji ad hoc dyktowanych bieżącymi interesami politycznymi.

Wydaje się również, że o ewentualnej przeciwwadze dla dobrze zorganizowanych ruchów religijnych decydować będzie sprawność organizacyjna prodemokratycznych organizacji pozarządowych, przypominających o znaczeniu wartości obywatelskich opartych na Pancasili. O ile wiele takich organizacji istnieje i podejmuje próby szerzenia postaw i pokojowego dialogu na tematy trudne, spotykają się one często z atakami

19 Zob. szerzej: K. Bielawski, Antykomunizm w Indonezji, [w:] Wyzwania gospodarcze i polityczne państw Dalekiego Wschodu, red. J. Marszałek-Kawa, G. Kądzielawski, K. Zamasz, Toruń 2018. 
rozemocjonowanych tłumów ${ }^{20}$. Aktywizm obywatelski w Indonezji zatem, ze względu na ryzyko wywołania niebezpiecznych starć i protestów, również wydaje się być zagrożony, a bez niego, jak się wydaje, nie ma szans na dalszy proces dojrzewania demokracji indonezyjskiej.

\section{Bibliografia}

\section{Monografie i czasopisma}

Arianti V., Mostarom T.R., Managing Religious Tensions: Indonesia's Current Dilemma, „Counter Terrorist Trends and Analyses” 2011, vol. 3, nr 3.

Aspinall E., Mietzner M., Indonesian Politics in 2014: Democracy's Close Call, „Bulletin of Indonesian Economic Studies" 2014, vol. 50, nr 3.

Aspinall E., Semi-Opponents in Power: The Abdurrahman Wahid and Megawati Soekarnoputri Presidencies, [w:] Soeharto's New Order and Its Legacy, red. E. Aspinall, G. Fealy, Canberra 2010.

Bertrand J., Legacies of the Authoritarian Past: Religious Violence in Indonesia's Moluccan Islands, „Pacific Affairs” 2002, vol. 75, nr 1.

Bielawski K., Antykomunizm w Indonezji, [w:] Wyzwania gospodarcze i polityczne państw Dalekiego Wschodu, red. J. Marszałek-Kawa, G. Kądzielawski, K. Zamasz, Toruń 2018.

Bielawski K., Szariat a prawa człowieka w Acehu, „Cywilizacja i Polityka” 2015, nr 13.

Bielawski K., Wybory gubernatorskie w Jakarcie w 2017 roku a problem radykalizmu, [w:] Systemy polityczne i kultura

20 Death of free speech, „The Jakarta Post”, https://www.thejakartapost. com/academia/2017/09/19/editorial-death-of-free-speech.html [dostęp: 17.09.2019]. 
prawna państw azjatyckich, red. J. Marszałek-Kawa, M. Bidziński, Toruń 2018.

Crouch M., Indonesia, Militant Islam and Ahmadiyah: Origins and Implications, ARC Federation Fellowship, „Islam, Shariah and Governance Background Paper Series" 2009, nr. 4. Fukuoka Y., Debating Indonesia's Reformasi: Bridging "Parallel Universes”, „Journal of Contemporary Asia” 2014, vol. 44, nr 3. Hasan N., Religious Diversity and Blasphemy Law. Understanding Growing Religious Conflict and Intolerance in Post-Suharto Indonesia, „Al-Jāmi'ah: Journal of Islamic Studies” 2017, vol. 55, nr 1.

Laskowska N., Indonezja, Warszawa 2012.

Rabasa A., Haseman J., The Military and Democracy in Indonesia. Challenges, Politics, and Power, Santa Monica 2002. Sangaji A., The security forces and regional violence in Poso, [w:] Renegotiating Boundaries. Local Politics in Post-Suharto Indonesia, red. H.S. Nordholt, G. van Klinken, Leiden 2007.

Warburton E., Jokowi and the New Developmentalism, „Bulletin of Indonesian Economic Studies” 2016, vol. 52, nr 3.

\section{Źródła internetowe}

Attorney General Muhammad Prasetyo: Don't Test My Resolve!, Tempo, https://en.tempo.co/read/643562/attorneygeneral-muhammad-prasetyo-dont-test-my-resolve.

D.A. Sinaga D.A., Almanar A., Setuningsih N., Gov't Officially Disbands Hizbut Tahrir Indonesia, Jakarta Globe, https:// jakartaglobe.id/context/govt-officially-disbands-hizbut-tahrir-indonesia.

Death of free speech, The Jakarta Post, https://www.thejakartapost.com/academia/2017/09/19/editorial-death-of-free-speech.html.

Lamb K., Fake news spikes in Indonesia ahead of elections, ht- 
tps://www.theguardian.com/world/2019/mar/20/fake-news-spikes-in-indonesia-ahead-of-elections.

Lamb K., 'I felt disgusted': inside Indonesia's fake Twitter account factories, „The Guardian”, https://www.theguardian. com/world/2018/jul/23/indonesias-fake-twitter-account-factories-jakarta-politic.

Lipson D., Indonesia's 'buzzers' paid to spread propaganda as political elite wage war ahead of election, $\mathrm{ABC}$, https:// www.abc.net.au/news/2018-08-13/indonesian-buzzers-paid-to-spread-propaganda-ahead-of-election/9928870.

Pepinsky T., Religion, ethnicity, and Indonesia's 2019 presidential election, New Mandala, https://www.newmandala.org/ religion-ethnicity-and-indonesias-2019-presidential-election/.

Perper R., Social media 'buzzers' are being paid by Indonesian political parties to spread propaganda ahead of local elections, Business Insider Australia, https://www.businessinsider.com.au/indonesia-election-buzzers-election-propaganda-2018-8.

Potkin F., Da Costa A.B., In Indonesia, Facebook and Twitter are 'buzzer' battlegrounds as elections loom, Reuters, https://www.reuters.com/article/us-indonesia-electionsocialmedia-insigh/in-indonesia-facebook-and-twitter-are-buzzer-battlegrounds-as-elections-loom-idUSKBN1QU0AS.

Power T., Jokowi's authoritarian turn, New Mandala, https:// www.newmandala.org/jokowis-authoritarian-turn/.

President Jokowi Clarifies Fake News Circulated in Social Media, Cabinet Secretariat of The Republic of Indonesia, https://setkab.go.id/en/president-jokowi-clarifies-fake-news-circulated-in-social-media/.

President Jokowi: Don't Trust Fake News, Hoaxes on Social Media, Cabinet Secretariat of The Republic of Indonesia, 
https://setkab.go.id/en/president-jokowi-dont-trust-fakenews-hoaxes-on-social-media/.

Renaldi R., Indonesia's 2019 Election Is Keeping Fake News

Fact Checkers Way Too Busy, Vice, https://www.vice.com/ en_asia/article/59v43d/indonesia-fake-news-presidential-election-jokowi-prabowo-hoax-season.

The World Factbook, https:/www.cia.gov/library/publications/ the-world-factbook/geos/id.html.

Yuniarni S., Why Are Ahmadiyah Followers in Indonesia Attacked?, Jakarta Globe, https://jakartaglobe.id/context/ahmadiyah-followers-indonesia-attacked/.

\section{Abstrakt}

Celem artykułu jest wskazanie potencjalnego kierunku rozwoju indonezyjskiej rzeczywistości politycznej po wyborach powszechnych w 2019 r. Wskazuje się szczególnie na dwa powiązane ze sobą problemy mające wpływ na wektory przyszłych zmian: dostrzec można narastające podziały społeczne oparte na tożsamości religijnej i etnicznej, a nadto coraz wyraźniejszą antagonizację poszczególnych grup. Elity polityczne Indonezji wykorzystują je w celu prowadzenia bieżącej rywalizacji politycznej. Odbywa się to ad hoc, zależnie od konfiguracji interesów, jednak konsekwencje społeczne takich działań mogą być dla przyszłości państwa o wiele poważniejsze. Zachodzi ryzyko trwałego wewnętrznego rozbicia społeczeństwa skutkującego ewentualnymi konfliktami oraz zanikiem praktyki merytorycznej dyskusji i dążenia do konsensusu. Jednym z uczestników rywalizacji politycznej jest także prezydent Joko Widodo, który również, mimo wcześniejszych oczekiwań jego wyborców, swoje rządy często opiera na decyzjach o autorytarnym charakterze. Druga kadencja prezydenta Indonezji okaże się kluczowa dla rozwoju lub wstrzymania procesów demokratyzacji tego państwa.

Słowa kluczowe: Indonezja, demokracja, radykalizm, Joko Widodo 


\begin{abstract}
The purpose of this article is to indicate potential directions Indonesian political reality will take in upcoming years after the general elections in 2019. There are two main problems that can shape future changes: increasing social divisions based on religious and ethnic identity with increasing hostility between different groups. Indonesia's political elites use those divisions in ongoing political rivalry, which is usualy done ad hoc, depending on the current interests. Social consequences of such actions might be dangerous for the future of the state. Permanent social division can lead to disappearance of peacful discussion and search of consensus. One of the participants in political rivalry is also President Joko Widodo, whose desicions seem to be based on more authoritarian than democratic character. The second term of his presidency will be crucial for the development or suspension of democratic processes in Indonesia.
\end{abstract}

Keywords: Indonesia, democracy, radicalism, Joko Widodo 


\title{
Katarzyna Sopolińska
}

\author{
Uniwersytet Mikołaja Kopernika w Toruniu \\ ORCID ID: https://orcid.org/0000-0001-6860-5530
}

\section{Wybory parlamentarne w Bhutanie w latach 2008-2018}

Położone we wschodnich Himalajach i graniczące z Chinami i Indiami Królestwo Bhutanu przez dekady było monarchią absolutną. Dopiero w 2008 r. ów system polityczny został przekształcony w monarchię konstytucyjną, kiedy to król Jigme Khesar Namgyel Wangchuck ustanowił pierwszą w historii państwa konstytucję, w efekcie czego wprowadzony został trójpodział władzy oraz nowy ustrój organów państwowych. Należy podkreślić, iż demokracja wprowadzona została z inicjatywy króla, a nie w wyniku oddolnych żądań obywateli, co wydaje się być rzadkością ${ }^{1}$. W procesie tworzenia zapisów ustawy zasadniczej wzorowano się na rozwiązaniach ustrojowych i legislacyjnych blisko stu państw ${ }^{2}$. Jak wynika z treści preambuły powodem i celem przyjęcia konstytucji była chęć wzmocnienia suwerenności Bhutanu, zapewnienie wolności, sprawiedliwość i spokoju, umocnienie jedności obywateli oraz ich szczęścia i dobrobytu ${ }^{3}$. Możliwe jednak, że jedną z przyczyn była też obawa, aby

1 Bhutan's Road to Democracy, https://www.cfr.org/interview/bhutans-road-democracy [dostęp: 18.11.2019].

2 Background of constitution, https://web.archive.org/web/20100715 193437/http://www.constitution.bt/html/sources/background.htm [dostęp: 18.11.2019].

3 Preamble, The Constitution of The Kingdom of Bhutan, https://www. nationalcouncil.bt/assets/uploads/docs/acts/2017/Constitution_of_Bhutan_2008.pdf [dostęp: 18.11.2019]. 
przyszłości w Bhutanie nie miała miejsca wojna domowa podobna do tej w Nepalu.

Wykres 1. Schemat władzy ustawodawczej w Bhutanie.

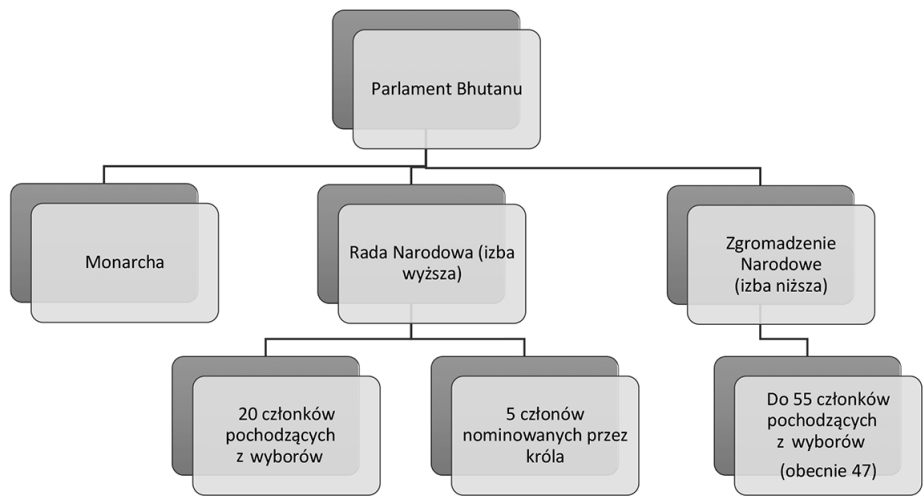

Źródło: opracowanie własne.

Zgodnie z konstytucją powszechna wola ludu, wyrażona poprzez okresowe wybory, ma być podstawą rządzenia w kraju4. Art. 10 Konstytucji Bhutanu stanowi, że władzę ustawodawczą w Królestwie sprawuje monarcha, Rada Narodowa i Zgromadzenie Narodowe (wykres 1). Rada Narodowa składa się z 25 członków, z czego 5 członków nominowanych jest przez króla, a 20 pochodzi z wyborów, po jednym z każdego okrę$\mathrm{gu}^{5}$. W Zgromadzeniu Narodowym z kolei może zasiadać do 55 członków (w każdej z omawianych kadencji było 47) wybieranych w okręgach proporcjonalnie do liczby ludności, nie mniej jednak niż dwóch i nie więcej niż siedmiu. Zgodnie z obowiązującą zasadą incompatibilitas, nie można być jednocześnie członkiem Rady Narodowej i Zgromadzenia Narodowego, a także łączyć tych funkcji ze sprawowaniem władzy w samorządzie

\footnotetext{
4 Art. 23, The Constitution...

5 Art. 10, The Constitution...
} 
terytorialnym. Ponadto członkowie Rady Narodowej nie mogą przynależeć do żadnej partii politycznej ${ }^{6}$.

Czynne prawo wyborcze przysługuje wyłącznie obywatelom Bhutanu, którzy ukończyli 18 lat. Ponadto wyborca musi być zarejestrowanym mieszkańcem danego okręgu wyborczego co najmniej na rok przed datą wyborów ${ }^{7}$. Prawo wybierania może zostać odebrane na skutek choroby psychicznej lub ułomności intelektualnej stwierdzonych przez sąd $\mathrm{d}^{8}$. $\mathrm{Z}$ kolei bierne prawo wyborcze przysługuje wyłącznie obywatelom Bhutanu, którzy są zarejestrowanymi wyborcami w danym okręgu, mają nie mniej niż 25 i nie więcej niż 65 lat, nie otrzymują pomocy finansowej ani żadnej innej ze strony rządowych, pozarządowych lub prywatnych podmiotów zagranicznych oraz spełniają kryterium wykształcenia ${ }^{9}$, tj. posiadają wykształcenie wyższe potwierdzone dyplomem uniwersyteckim. Kandydatami nie mogą być zaś osoby, które m.in.: popełniły przestępstwo i zostały skazane na karę więzienia; były uznane za winne praktyk korupcyjnych podczas wyborów; zostały wydalone ze służby cywilnej lub sektora korporacyjnego, zawarły związek małżeński z osobą niebędącą obywatelem Królestwa lub pracują jako urzędnik państwowy ${ }^{10}$. W obliczu tak skonstruowanego prawa wyborczego nie można stwierdzić, iż wybory w Bhutanie są wyborami powszechnymi. Według zasady powszechności wyborów każdy obywatel ma zarówno czynne, jak i bierne prawo wyborcze, a wprowadzenie cenzusów wyborczych (poza odpowiednim wiekiem i zdrowiem psychicznym) stoi w konflikcie z nią. W Bhutanie zaś w biernym

6 Więcej na temat systemu politycznego Bhutanu w: K. Sopolińska, Królestwo Smoka. System polityczny Bhutanu: zarys problematyki, „Przegląd Prawa Konstytucyjnego" 2019, nr 1 (47), s. 227-241.

7 Art. 23, The Constitution...

8 Ibidem.

9 Ibidem.

10 Ibidem. 
prawie obowiązuje cenzus wykształcenia, ale także widoczna jest dyskryminacja i dyskwalifikacja osób zawierających związki małżeńskie z osobami niebędącymi obywatelami państwa. Zarówno w wyborach do Zgromadzenia Narodowego, jak i Rady Narodowej przyjęto ordynację większościową. Wyborca wybiera jednego kandydata spośród wszystkich umieszczonych na danej liście. Jest to często stosowana w okręgach jednomandatowych lub przy wyborze na pojedyncze stanowisko metoda FPTP (ang. first past the post).

Pierwsze wybory parlamentarne w Bhutanie odbyły się w 2008 r. Zanim jednak Bhutańczycy przystąpili do wybierania członków Zgromadzenia Narodowego i Rady Narodowej przeprowadzono 21 kwietnia 2007 r. mock election, czyli tzw. wybory na niby, na próbę, aby przygotować ludność na nadchodzące zmiany i pokazać w jaki sposób się głosuje. Odbyły się one we wszystkich 47 okręgach, w których miały odbyć się oficjalne wybory do Zgromadzenia Narodowego. Startowały w nich cztery fikcyjne partie, z których każda odzwierciedlała inne wartości i cechy: partia niebieska (Druk Blue Party) - uczciwość i odpowiedzialność, zielona (Druk Green Party) - środowisko i ekologia, czerwona (Druk Red Party) - rozwój przemysłowy, żółta (Druk Yellow Party) - tradycja i zwyczaje ${ }^{11}$. Dwie partie, które zdobyły najwięcej głosów przystąpiły do drugiej tury (28 maja 2007 r.), w której wystawiły swoich kandydatów - losowo wybranych uczniów ze szkół średnich. Frekwencja w I turze wyniosła 44\%, w drugiej 66\%. Liczba zarejestrowanych wyborców wynosiła 283506 osób, aczkolwiek szacuje się, że uprawnionych do rejestracji na liście wyborców mogło być w sumie ok. 400 tys. osób ${ }^{12}$. Wyniki pierwszej tury mock election przedsta-

11 V. Kumar, Political Parties and Participation, [w:] Bhutan: Contemporary Issues and Perspectives, red. Rsjesh S. Kharat, New Dehli 2016, s. $43-44$.

12 S. Sengupta, Line Up and Pick a Dragon: Bhutan Learns to Vote, 
wia wykres 2. W drugiej turze partia żółta („tradycja i zwyczaje”) wygrała w 46 z 47 okręgów. Jej zwycięstwo mogło być związane z kolorem żółtym, który w Bhutanie kojarzony jest przede wszystkim z rodziną królewską (szarfę tego koloru noszą tylko jej członkowie), a ta cieszy się wysokim poparciem społecznym ${ }^{13}$. Należy także nadmienić, że podczas „wyborów” obecni byli obserwatorzy z Organizacji Narodów Zjednoczonych oraz z Indii.

Wykres 2. Wyniki I tury mock election

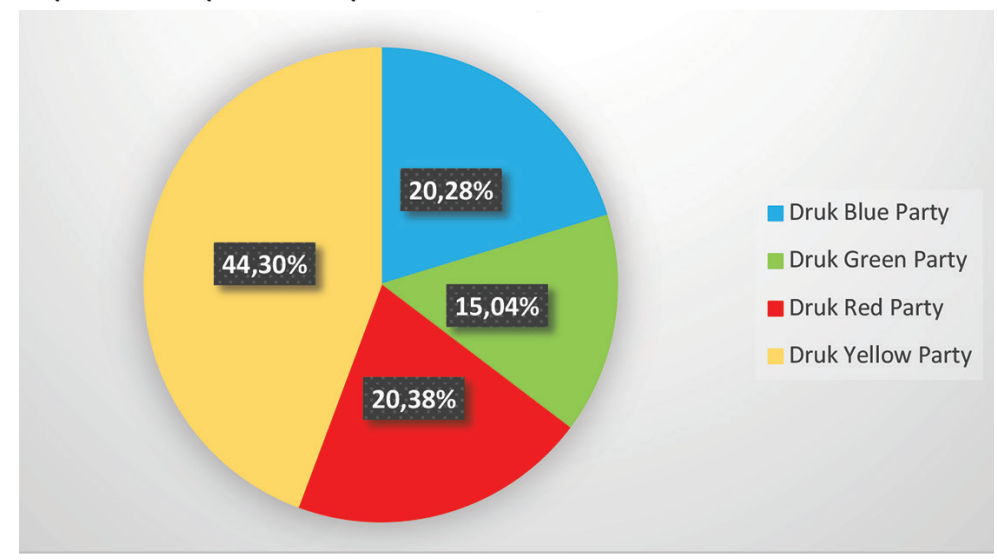

Źródło: opracowanie własne.

Pierwsze oficjalne wybory do Zgromadzenia Narodowego odbyły się 24 marca 2008 r. Miały się one odbyć się w dwóch turach: w I turze wyborcy głosować mieli na konkretną partię, następnie dwie partie z najwyższym wynikiem wystawić miały w II turze kandydatów w 47 okręgach wyborczych. Wybory te jednak wyjątkowo rozstrzygnęły się w jednej turze, gdyż tylko dwie partie zostały pomyślnie zarejestrowane, w związku z czym tura wyłaniająca dwa najbardziej popierane przez spo-

https://www.nytimes.com/2007/04/24/world/asia/24bhutan.html [dostęp: 19.11.2019].

13 V. Kumar, Political..., s. 45. 
łeczeństwo ugrupowania była zbędna. O miejsca w Zgromadzeniu Narodowym rywalizowały Partia Pokoju i Dobrobytu Bhutanu (DPT, ang. The Bhutan Peace and Prosperity Party) oraz Ludowa Partia Demokratyczna (PDP, ang. People's Democratic Party), trzecia partia funkcjonująca wówczas w Bhutanie - Bhutańska Partia Narodowa (BNP, ang. Bhutan National Party) - nie przystąpiła do wyborów z powodu anulowania wniosku rejestracyjnego ${ }^{14}$.

Kampania wyborcza w poszczególnych okręgach rozpoczęła się oficjalnie 7 lutego $2008 \mathrm{r}$. i trwała do 22 marca, głosowanie zaś miało miejsce 24 marca. Frekwencja wyborcza wyniosła 79,4\%. Początkowo do wiadomości publicznej podano, że DPT zdobyła 44 mandaty, PDP zaś 3. Okazało się jednak, że w jednym okręgu doszło do pomyłki podczas telefonicznego przekazywania wyników i faktycznym zwycięzcą został kandydat DPT, co dało ugrupowaniu 45 mandatów kosztem jednego mandatu dla PDP ${ }^{15}$. Przyczyn takiej dysproporcji można doszukiwać się w braku znaczących różnic programowych obu partii, ale także w postrzeganiu przez Bhutańczyków DPT jako ugrupowania bardziej rojalistycznego, ściślej powiązanego z królem i państwowym biznesem.

Dwa mandaty zdobyte w $2008 \mathrm{r}$. nie przeszkodziły opozycji w przejęciu władzy w kolejnych wyborach w 2013 r., w których wystartowały cztery ugrupowania. W I turze, która odbyła się 31 maja, udział wzięło 211018 wyborców z 381790 uprawnionych, czyli 55,27\%. Najwięcej głosów zdobyła sprawująca do tej pory władzę DPT, a drugie miejsce zajęła PDP, dzięki

14 G. Sithey, T. Dorji, Bhutan's first parliamentary elections 2008, s. 228-238, https://www.researchgate.net/publication/326071022_Bhutan's_first_parliamentary_elections-2008 [dostęp: 19.11.2019].

15 Corrected: Bhutan corrects poll results, opposition shrinks, https://www.reuters.com/article/us-bhutan-election/corrected-bhutan-corrects-poll-results-opposition-shrinks-idUSDEL16203420080327 [dostęp: 19.11.2019]. 
czemu obie partie mogły wziąć udział w II turze. Partia Druk Nyamrup Tshogpa (DNT, ang. Bhutan United Party) zdobyła 17,04\%, zaś Druk Chirwang Tshogpa (DCT) 5,90\%. W II turze (13 lipca), w której frekwencja wyniosła 66,23\%, w głosowaniu zwyciężyła jednak Ludowa Partia Demokratyczna (PDP) i to jej przypadły 32 miejsca w Zgromadzeniu Narodowym ${ }^{16}$.

Ciekawą sytuacją, jaka miała miejsce jeszcze przed wyborami, było niedopuszczenie do startu partii Bhutan Kuen-Nyam (BKN) z powodu braku kandydata z wykształceniem wyższym w okręgu Gasa (w 26 pozostałych warunek ten został spełniony). Cztery partie biorące udział w wyborach wystąpiły do Bhutańskiej Komisji Wyborczej z prośbami o dopuszczenie do wyborów BKN, jednak ta, zgodnie z obwiązującym prawem, ponownie odmówiła zgody na start ${ }^{17}$. Wydaje się, że politycy działający dopiero od pięciu lat w warunkach demokratycznych wiedzą lepiej, czym powinna być prawdziwa demokracja, niż politycy funkcjonujący w długoletniej tradycji demokratycznej. Incydent ten jest też dowodem na brak powszechności wyborczej i dyskryminację ze względu na poziom wykształcenia.

Zaskakująca może być też ostateczna wygrana PDP po zwycięstwie DPT w I turze. Jednak pomiędzy 24 marca a 13 lipca 2013 r. (I i II tura) zmieniła się sytuacja w relacjach pomiędzy Bhutanem a Indiami, gdyż te zmniejszyły dostawy subsydiowanego gazu oraz nafty do Bhutanu, co Bhutańczycy uznali jako karę za rozwijanie stosunków z Chińską Republiką Ludową. Kwestia ta stała się głównym elementem kampanii politycznej rywalizujących ze sobą partii, co jak wydaje się, przesądziło o wyniku wyborów, gdyż to właśnie PDP opowiadała się, w opo-

16 C. Dema, Primaries 2008-18: An Analysis, https://www.businessbhutan.bt/2018/09/25/primaries-2008-18-an-analysis/ [dostęp: 21.11.2019].

17 O. Ahmad, Experiments With Democracy in Bhutan, https://india. blogs.nytimes.com/2013/06/15/experiments-with-democracy-in-bhu$\tan$ /?ref=bhutan [dostęp: 21.11.2019]. 
zycji do rządzącej wówczas DPT, za pogłębieniem stosunków z Indiami i wyhamowanie współpracy chińsko-bhutańskiej ${ }^{18}$.

Następne wybory w 2018 r. przyniosły kolejną zmianę partii rządzącej. W I turze (15 września) sprawująca władzę PDP zajęła trzecie miejsce, uzyskując 27,44\% głosów, co spowodowało, że zabrakło jej w II turze (18 października) i tym samym straciła dotychczasowe 32 miejsca w Zgromadzeniu Narodowym. W I turze najwięcej głosów uzyskały partie DNT $(31,85 \%)$ i DPT $(30,92 \%)$ i to one brały udział w II turze. Ugrupowanie BKN uzyskało $9,78 \%$. Frekwencja wyniosła $66,36 \%$ - zagłosowało 291098 z 438663 zarejestrowanych wyborców. W II turze frekwencja wzrosła do 71,46\% dzięki 313473 głosującym. Wybory zwyciężyło ugrupowanie DNT (54,95\% głosów), które uzyskało 30 miejsc w Zgromadzeniu Narodowym. DPT zakończyło wybory z wynikiem $45,05 \%$ i zdobyło 17 miejsc, o 2 więcej w porównaniu z kadencją 2013-2018.

Wybory te ukazały też ciągły rozwój stanowisk programowych bhutańskich partii. Różnice w koncepcjach i postulatach są coraz wyraźniejsze. Partia DNT proponowała dywersyfikację gospodarki poprzez ograniczenie uzależnienia od sektora hydroelektrycznego, który z kolei jest uzależniony od Indii, największego inwestora w elektrownie wodne, a zarazem największego nabywcy bhutańskiej energii wodnej. Zaproponowano także wprowadzenie biogazu i samochodów elektrycznych, co miało być odpowiedzią na sytuację z 2013 r., kiedy to Indie ograniczyły dostawy gazu. Odmienne poglądy na gospodarkę ma DPT, której program skupiał się na kontynuacji wzrostu gospodarczego opartego na tradycyjnych sektorach tj. elektrowni wodnych i turystyki. Różnice programowe dostrzegalne są również w polityce społecznej - DNT zachęcała do pracy w rolnictwie, proponowała zwiększenie płac w sektorze publicznym,

18 Bhutan's opposition party scores upset win, https://www.aljazeera. com/news/asia/2013/07/ 2013713125727754144.html [dostęp: 21.11.2019]. 
a także skoncentrowanie się na opiece zdrowotnej. Z kolei DPT priorytetowo potraktowało zmniejszenie deficytu handlowego, postulowało rozszerzenie roli sektora prywatnego i zminimalizowanie interwencji rządu w gospodarkę ${ }^{19}$.

Wykres 3. Wyniki I tury wyborów do Zgromadzenia Narodowego przedstawione $\mathrm{w}$ procentach

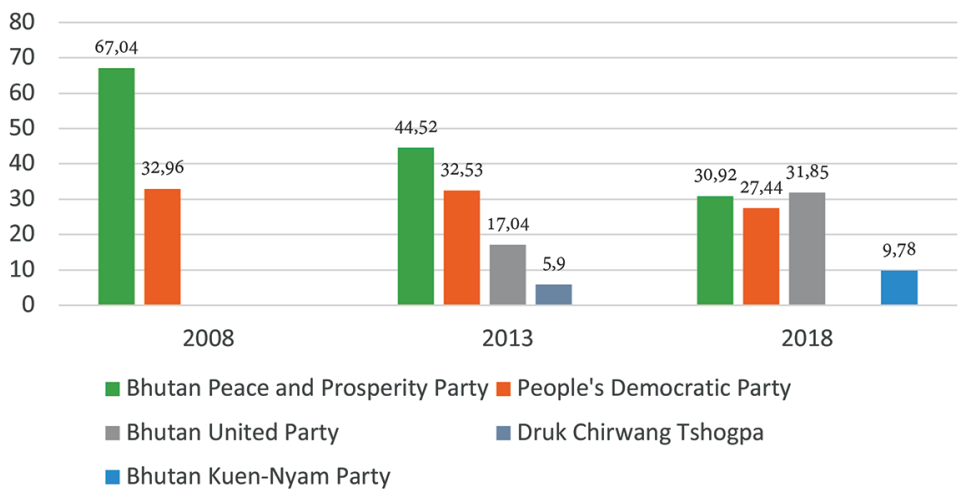

Źródło: opracowanie własne.

Wykres 4. Wyniki II tury wyborów do Zgromadzenia Narodowego przedstawione $\mathrm{w}$ procentach

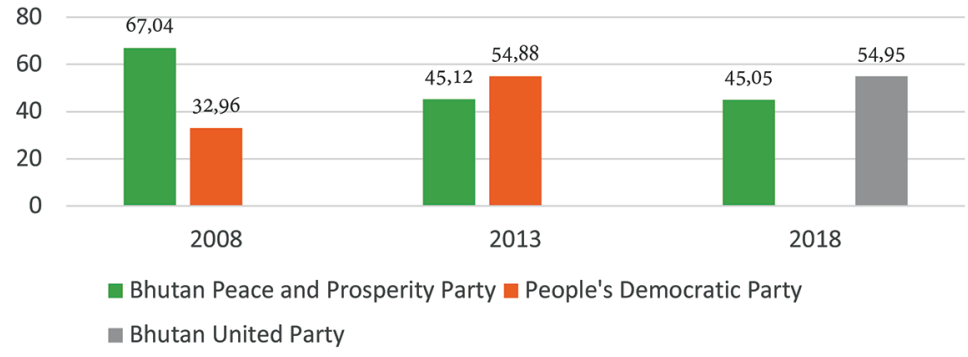

Źródło: opracowanie własne.

19 Bhutan elections explained, https://www.himalmag.com/bhutan-parliament-national-assembly-elections-2018-explainer/ [dostęp: 21.11.2019]. 
Wykresy 3 i 4 przedstawiają wyniki wyborów z lat 2008, 2013 i 2018 kolejno w I i II turze, natomiast tabela 1 przedstawia frekwencję w tych latach.

Tabela 1. Wyniki II tury wyborów do Zgromadzenia Narodowego przedstawione $\mathrm{w}$ procentach

\begin{tabular}{|l|c|c|c|c|c|}
\hline & 2008 & \multicolumn{2}{|c|}{2013} & \multicolumn{2}{c|}{2018} \\
\hline & \multicolumn{1}{|c|}{ I tura } & I tura & II tura & I tura & II tura \\
\hline Liczba zarejestrowanych wyborców & 318655 & 381790 & 381790 & 438663 & 438663 \\
\hline Liczba oddanych głosów & 253012 & 211018 & 252853 & 291098 & 313473 \\
\hline Frekwencja & $79,4 \%$ & $55,27 \%$ & $66,23 \%$ & $66,36 \%$ & $71,46 \%$ \\
\hline
\end{tabular}

Źródło: opracowanie własne.

Pierwsze w historii wybory do Rady Narodowej Bhutanu odbyły się 31 grudnia 2007 r., jednak nie były one przeprowadzone we wszystkich okręgach. Z powodu braku chętnych i niespełnienia wymogu co najmniej dwóch startujących kandydatów w każdym okręgu, wybory w pięciu z nich zostały odroczone i odbyły się w nich dopiero 29 stycznia 2008 r., już niezależenie od liczby zgłoszonych osób. Kandydaci wybierani są na specjalnych zebraniach lokalnej społeczności (zomdus) i w odróżnieniu od kandydatów do Zgromadzenia Narodowego nie mogą przynależeć do żadnej partii politycznej oraz muszą posiadać wyższe wykształcenie potwierdzone dyplomem uniwersyteckim. 31 grudnia 2007 r. w 15 jednomandatowych okręgach rywalizowało łącznie 43 kandydatów, najwięcej, bo po czterech, wystawiły okręgi Paro, Samtse, Dagana i Mongar. Wybrano 3 kobiety i 12 mężczyzn, zaś najmłodszy członek Rady miał 26 lat i miała to być jego pierwsza praca po studiach ${ }^{20}$. W drugim terminie w pięć okręgach wystartowało dziewięć osób. 79\% uprawnionych obywateli zarejestrowało się, aby móc zagłosować w wyborach.

20 Bhutan announces results of first vote, https://www.reuters.com/article/idINIndia-31205620080102 [dostęp: 22.11.2019]. 
23 kwietnia 2013 r. odbyły się kolejne wybory do Rady Narodowej. Tym razem tylko w dwóch okręgach zgłosił się jeden kandydat, ale zamiast przesuwać wybory na inny termin, wprowadzono formę referendum, tj. obywatelom tych dwóch jednostek terytorialnych dano możliwość głosowania za lub przeciw. Łącznie zarejestrowano 67 kandydatów, najwięcej chętnych (siedmiu) wystartowało w okręgu Samtse. Co ciekawe, na drugą kadencję wybrano ponownie tylko dwóch kandydatów, przy czym jeden z nich nie miał w ogóle kontrkandydata. Aby wziąć udział w wyborach zarejestrowało się 379819 wyborców, ale faktycznie zagłosowało 171 544, czyli 45,16\%.

W 2018 r. frekwencja wyniosła 54,29\%. W wyborach zagłosowało 234535 obywateli, czyli o 60 tys. więcej niż w 2013 r., zarejestrowanych wyborców było zaś $432030^{21}$. W 20 okręgach wystartowało 127 kandydatów - najmniej w Bumthangu (2), najwięcej w Mongar (13) 22 . Średnia liczby kandydatów na okręg wyniosła nieco ponad sześć. Pięciu kandydatów zostało wybranych na kolejną kadencję, z czego Jigme Wangchuk z okręgu Samdrup Jongkhar został wybrany na członka Rady trzeci raz z rzędu. Siedmiu członków Rady w kadencji 2013-2018 przegrało w swoich okręgach i musiało pożegnać się z tą zaszczytną funkcją. Warto podkreślić, że średnia wieku członków wybranych do Rady Narodowej w 2018 r. wynosiła 40,2 lat. Najmłodszy z nich miał 31 lat, najstarszy 54. Stosunkowo młody wiek osób zasiadających w Radzie wynika przede wszystkim z wymogu posiadania wykształcenia wyższego. Starsze pokolenia nie miały możliwości studiować, gdyż bhutańska edukacja przez lata była na bardzo niskim poziomie. Analizując biografie polityków

21 Record turnout in Bhutan elects third National Council, https:// www.idea.int/news-media/news/record-turnout-bhutan-elects-third-national-council [dostęp: 22.11.2019].

22 Election Results, http://results.ecb.bt/nc2018/index.php [dostęp: 22.11.2019]. 
można zauważyć, że wielu z nich studiowało na zagranicznych uniwersytetach, m.in. w Indiach, Stanach Zjednoczonych czy w Europie E $^{23}$.

Podsumowując, trudno mówić o całkowicie powszechnych wyborach, kiedy bierne prawo wyborcze jest ograniczone przez cenzus wyższego wykształcenia, szczególnie gdy wciąż nie jest ono tak powszechne, a ludność, zwłaszcza z biedniejszych prowincji, ma utrudniony dostęp do uniwersytetów. Poddając ocenie dziesięć lat demokracji w Bhutanie należy zauważyć przede wszystkim partycypację wyborczą na wysokim poziomie, porównywalną z poziomem w państwach np. europejskich. Zarówno liczba zarejestrowanych wyborców, jak i frekwencja wyborcza rosną. Również coraz więcej osób decyduje się na start wyborach, co widać zwłaszcza po liczbie kandydatów do Rady Narodowej - w 2008 r. było ich 53, w 2013 r. 67, w 2018 r. już 127, czyli prawie o połowę więcej w porównywaniu z 2013 r. Niewątpliwą zaletą obecnego systemu jest pojawienie się pluralizmu partyjnego, gdzie oprócz dwóch stale obecnych w Zgromadzeniu Narodowym partii są też inne działające ugrupowania biorące aktywny udział w tworzeniu opozycji pozaparlamentarnej. Zaczyna się też krystalizować coraz bardziej widoczna różnorodność programowa partii, co szczególnie widać w odniesieniu do pierwszych wyborów w 2008 r., gdzie praktycznie obie startujące partie były zbieżne programowo. Wydaje się też, że trzy kolejne zmiany rządu w ciągu trzech wyborów parlamentarnych odzwierciedlają powszechny entuzjazm do demokracji wśród bhutańskiego elektoratu oraz, co ważniejsze, niechęć do umocnienia systemu dwupartyjnego w państwie.

23 CV zawierające informacje o wieku, wykształceniu i doświadczeniu zawodowym członków Rady Narodowej Bhutanu dostępne są na oficjalnej stronie: https://www.nationalcouncil.bt/en/member/list_of_members [dostęp: 22.11.2019]. 


\section{Bibliografia}

Ahmad O., Experiments With Democracy in Bhutan, https://india.blogs.nytimes.com/2013/06/15/experiments-with-democracy-in-bhutan/?ref=bhutan.

Background of constitution, https://web.archive.org/web/2010 0715193437/http://www.constitution.bt/html/sources/background.htm.

Bhutan announces results of first vote, https://www.reuters. com/article/idINIndia-31205620080102.

Bhutan elections explained, https://www.himalmag.com/ bhutan-parliament-national-assembly-elections-2018-expl ainer/.

Bhutan's Road to Democracy, https://www.cfr.org/interview/ bhutans-road-democracy.

Bhutan's opposition party scores upset win, https://www.aljazeera.com/news/asia/2013/07/ 2013713125727754144.html.

Corrected: Bhutan corrects poll results, opposition shrinks, https://www.reuters.com/article/us-bhutan-election/corrected-bhutan-corrects-poll-results-opposition-shrinks-idUSDEL16203420080327.

Dema C., Primaries 2008-18: An Analysis, https://www.businessbhutan.bt/2018/09/25/primaries-2008-18-an-analysis/.

Election Results, http://results.ecb.bt/nc2018/index.php.

Kumar V., Political Parties and Participation, [w:] Bhutan: Contemporary Issues and Perspectives, red. Rsjesh S. Kharat, New Dehli 2016.

Record turnout in Bhutan elects third National Council, https://www.idea.int/news-media/news/record-turnout-bhutan-elects-third-national-council.

Sengupta S., Line Up and Pick a Dragon: Bhutan Learns to Vote, https://www.nytimes.com/2007/04/24/world/asia/24 bhutan.html.

Sithey G., Dorji T., Bhutan's first parliamentary elections 2008, 
https://www.researchgate.net/publication/326071022_ Bhutan's_first_parliamentary_elections-2008.

Sopolińska K., Królestwo Smoka. System polityczny Bhutanu zarys problematyki, „Przegląd Prawa Konstytucyjnego” 2019, nr 1 (47).

The Constitution of The Kingdom of Bhutan, https://www.nationalcouncil.bt/assets/uploads/docs/acts/2017/Constitution_of_Bhutan_2008.pdf.

\begin{abstract}
Abstrakt
Celem niniejszego artykułu było zaprezentowanie i omówienie wyników wyborów parlamentarnych w Królestwie Bhutanu w latach 2008, 2013 i 2018. Przedstawiono rozwój partycypacji wyborczej na przestrzeni dziesięciu lat, jej problemy i wyzwania, a także główne zasady prawa wyborczego. Ukazany zostały sposób wprowadzania demokracji oraz metody nauczanie obywateli Bhutanu jak głosować m.in. poprzez przeprowadzenie „wyborów na niby” (mock election). Główną metodą badawczą była analiza treści dokumentów znajdujących się na oficjalnych stronach internetowych oraz artykułów prasowych odnoszących się do tematu wyborów.
\end{abstract}

Słowa kluczowe: Królestwo Bhutanu, wybory parlamentarne, monarchia konstytucyjna, władza ustawodawcza, prawo wyborcze

\begin{abstract}
The purpose of this article was to present and discuss the results of the 2008, 2013 and 2018 general elections in the Kingdom of Bhutan. The development of electoral participation over 10 years, its problems and challenges as well as the main principles of the electoral law were presented. The article shows how democracy is implemented and how Bhutanese citizens were taught how to vote, for example by holding mock elections. The main research method was the analysis of the content of documents on official websites and press articles related to the topic of elections.
\end{abstract}

Keywords: Kingdom of Bhutan, parliamentary elections, constitutional monarchy, legislative authority, electoral law 